\title{
TNX GeoSiphon Cell (TGSC-1) Phase II Minimum Flushing Velocity Deployment/Demonstration Final Report
}

by

M. A. Phifer

Westinghouse Savannah River Company

Savannah River Site

Aiken, South Carolina 29808

F. C. Sappington

R. L. Nichols

This paper was prepared in connection with work done under the above contract number with the U. S. Department of Energy. By acceptance of this paper, the publisher and/or recipient acknowledges the U.S. Government's right to retain a nonexclusive, royalty-free license in and to any copyright covering this paper, along with the right to reproduce and to authorize others to reproduce all or part of the copyrighted paper. 


\section{DISCLAIMER}

This report was prepared as an account of work sponsored by an agency of the United States Government. Neither the United States Government nor any agency thereof, nor any of their employees, makes any warranty, express or implied, or assumes any legal liability or responsibility for the accuracy, completeness, or usefulness of any information, apparatus, product, or process disclosed, or represents that its use would not infringe privately owned rights. Reference herein to any specific commercial product, process, or service by trade name, trademark, manufacturer, or otherwise does not necessarily constitute or imply its endorsement, recommendation, or favoring by the United States Government or any agency thereof. The views and opinions of authors expressed herein do not necessarily state or reflect those of the United States Government or any agency thereof.

This report has been reproduced directly from the best available copy.

Available to DOE and DOE contractors from the Office of Scientific and Technical Information, P.O. Box 62, Oak Ridge, TN 37831; prices available from (615) 576-8401.

Available to the public from the National Technical Information Service, U.S. Department of Commerce; 5285 Port Royal Road, Springfield, VA 22161. 
TNX GEOSIPHON ${ }^{\mathrm{TM}}$ CELL (TGSC-1)

PHASE II MINIMUM FLUSHING VELOCITY

DEPLOYMENT / DEMONSTRATION FINAL REPORT (U)

M. A. Phifer, SRTC/EST

F. C. Sappington, SRTC/EST

R. L. Nichols, SRTC/EST

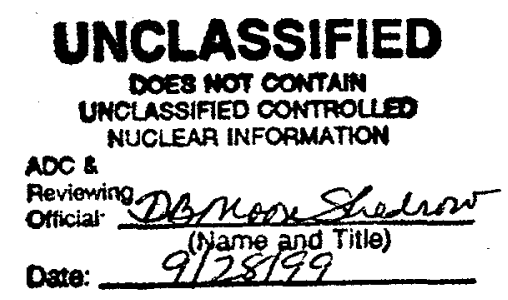

Westinghouse Savannah River Company

Savannah River Site

Aiken SC, 29808 


\section{DISCLAIMER}

Portions of this document may be illegible in electronic image products. Images are produced from the best available original document. 
TNX GEOSIPHON ${ }^{\mathrm{TM}}$ CELL (TGSC-1)

\section{PHASE II MINIMUM FLUSHING VELOCITY}

\section{DEPLOYMENT / DEMONSTRATION FINAL REPORT (U)}

Prepared by:

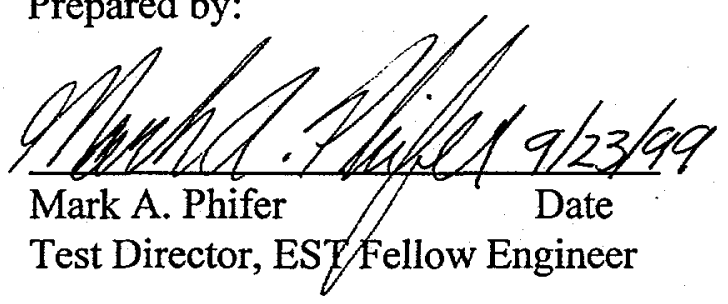

Reviewed by:

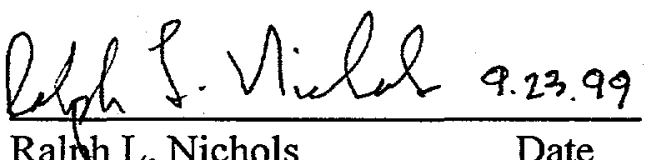

Ralph L. Nichols Date

Alternate Test Director, EST Principal Engineer

Reviewed by:

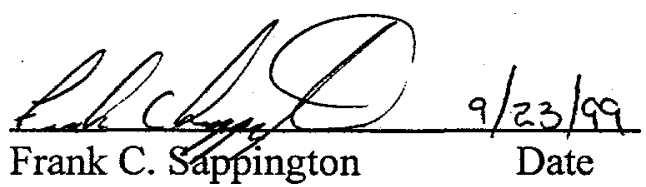

Alternate Test Director, EST Principal Engineer

Approved by:

DBmore thenos $9 / 29 / 99$

D. B. Moore-Shedrow Date

EST Level 2 Manager

Westinghouse Savannah River Company

Savannah River Site

Aiken SC, 29808 
Left Blank Intentionally 
Acknowledgments:

Appreciation is expressed to the following Environmental Sciences and Technology Department personnel for their contributions to this work:

- M. E. Denham for geochemical consultation.

- C. R. Betivas for sample collection.

- K. L. Dixon for automated data collection assistance.

- R. D. Raymond for chlorinated volatile organic compound analysis. 
Left Blank Intentionally 


\section{TABLE OF CONTENTS}

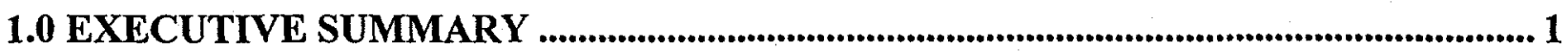

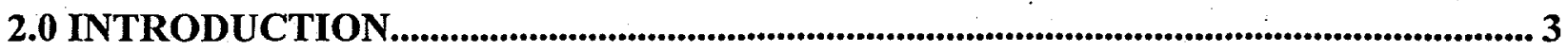

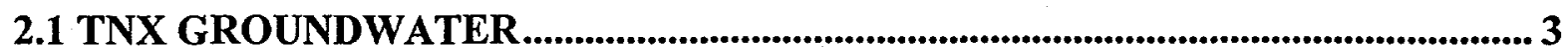

2.2 GEOSIPHON ${ }^{\mathrm{TM}}$ CELL AND ZERO-VALENT IRON TECHNOLOGIES ................ 3

2.3 ZERO-VALENT IRON LABORATORY STUDY ...................................................3

2.4 TNX GEOSIPHON CELL (TGSC-1)........................................................................................ 4

2.4.1 Phase I Testing ..................................................................................................................... 4

2.4.2 Phase II Single-Cell Testing................................................................................................. 4

2.5 PHASE II MINIMUM FLUSHING VELOCITY TEST OBJECTIVE.................... 5

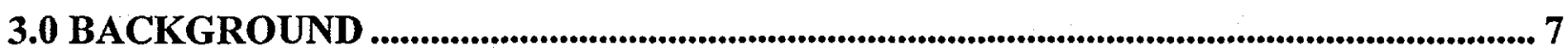

3.1 SIPHON TECHNOLOGY OVERVIEW ............................................................... 7

3.2 MINIMUM FLUSHING VELOCITY PRELIMINARY EVALUATION.................. 9

3.3 PHASE II MINIMUM FLUSHING VELOCITY PERMITTING

ACTIVITIES OVERVIEW ................................................................................... 11

4.0 MINIMUM FLUSHING VELOCITY HYDRAULIC TESTS ......................................... 13

4.1 MINIMUM FLUSHING VELOCITY HYDRAULIC TEST DESIGN ....................13

4.2 MINIMUM FLUSHING VELOCITY HYDRAULIC TEST RESULTS.................. 14

4.2.1 Continuous 2-Inch MFV Siphon Line............................................................................... 14

4.2.1.1 Continuous 2-Inch MFV Siphon Line Installation ........................................ 14

4.2.1.2 Continuous 2-Inch MFV Siphon Line Test Results Overview ....................... 16

4.2.1.3 Continuous 2-Inch MFV Siphon Line Test April 5 Results ........................... 17

4.2.1.4 Continuous 2-Inch MFV Siphon Line Test April 6 Results .......................... 18

4.2.1.5 Continuous 2-Inch MFV Siphon Line Test Temperature Results................... 18

4.2.2 2-Inch Upward Leg to 1-1/4-Inch Crest and Downward Leg MFV

Siphon Line Results ...............................................................................................................19

4.2.2.1 2- to 1-1/4-Inch MFV Siphon Line Installation ............................................ 19

4.2.2.2 2- to 1-1/4-Inch MFV Siphon Line Test Results Overview............................. 21

4.2.2.3 2- to 1-1/4-Inch MFV Siphon Line Test April 23 Results ................................. 23

4.2.2.4 -2 to 1-1/4-Inch MFV Siphon Line Test April 29 Results ............................... 24

4.2.2.5 2- to 1-1/4-Inch MFV Siphon Line Test Temperature Results.......................... 24

4.3 COMBINATION MFV AND CONTINUOUS NITROGEN-PURGE

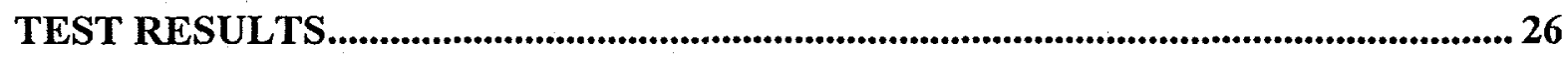

4.3.1 Combination MFV / CNP Test Overview ..............................................................26

4.3.2 Initial MFV Stage Results ................................................................................... 26

4.3.3 Secondary CNP Stage Results.................................................................................... 26

4.3.4 Final MFV Stage Results............................................................................................. 27

4.3.5 Sampling Atmospheric Leakage Significance ............................................................ 27 
TABLE OF CONTENTS (continued)

4.4 MFV / CNP TEST RESULT SUMMARY ....................................................................... 29

5.0 PHASE II MFV SAMPLING AND ANALYSIS............................................................... 31

5.1 SAMPLING AND ANALYSIS.............................................................................................. 31

5.2 SAMPLING AND ANALYSIS RESULTS ................................................................... 33

5.2.1 Field Parameters ............................................................................................................... 33

5.2.2 Chlorinated Volatile Organic Compounds.................................................................. 36

5.2.3 Dissolved Gasses and Gasses......................................................................................... 40

5.2.3.1 Dissolved gasses in Water ....................................................................... 41

5.2.3.2 Siphon Crest Accumulated Gas .................................................................... 46

5.2.3.3 Dissolved Gasses and Gasses Summary..................................................... 50

5.2 .4 Toxicity.............................................................................................................................51

5.3 SAMPLING AND ANALYSIS SUMMARY ................................................................52

6.0 EXISTING CELL OPERATION OPTIONS.................................................................5 55

6.1 MFV OPERATION MODE SUMMARY .....................................................................55

6.2 EXISTING CELL OPERATION OPTIONS OVERVIEW.......................................56

6.2.1 Air Chamber Operational Mode....................................................................................5 56

6.2.1.1 Air Chamber Recharge Utilizing a Nitrogen-Driven Vacuum Pump............. 56

6.2.1.2 Air Chamber Recharge from an Artesian Well ............................................ 57

6.2.1.3 Air Chamber Recharge from another Water Source .................................... 58

6.2.1.4 Air Chamber Recharge Utilizing a Solar-Powered Vacuum Pump ............... 58

6.2.2 Continuous Nitrogen-Purge Operational Mode ....................................................... 59

6.2.3 Continuous Water-Driven Eductor, Venturi, Or Pump Operational

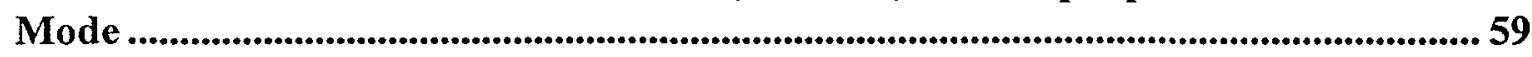

6.2.4 Other Operational Modes...................................................................................................... 60

6.2.5 De-gassing Reduction Enhancements............................................................................ 61

6.3 EXISTING CELL OPERATION OPTIONS SUMMARY AND

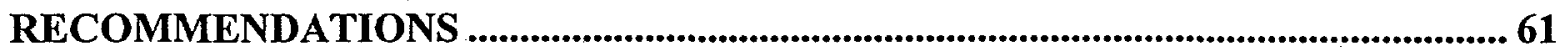

7.0 ALTERNATE GEOSIPHON CELL CONFIGURATION...................................................63

8.0 CONCLUSIONS AND RECOMMENDATIONS.............................................................67

REFERENCES.................................................................................................................................. 71

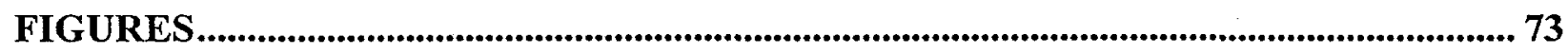

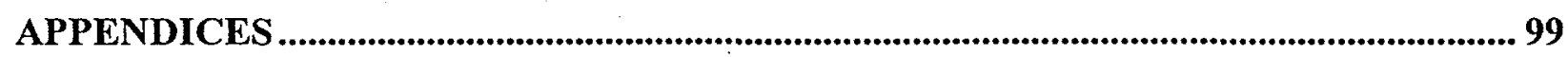




\section{LIST OF TABLES}

Table 1, Calculated Flows and Velocities versus Minimum Flushing Velocity......................... 10

Table 2, Minimum Flushing Velocity Test Siphon Line Configurations .................................. 13

Table 3, Monitoring Location, Details, and Parameters ....................................................... 14

Table 4, TGSC-1 MFV 2-Inch Continuous Siphon Line As-Built Details................................. 16

Table 5, TGSC-1 MFV 2-Inch Upward Leg to 1-1/4 -Inch Crest and Downward Leg

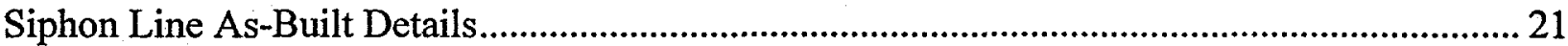

Table 6, Gas Accumulation Rates Versus Temperature .......................................................... 25

Table 7, Volume Factor Difference Versus Duration Factor Difference...................................29

Table 8, Monitoring Location, Chemical Parameter Groups, and Sampling Method .................. 31

Table 9, Chemical Parameters, Analytical Method, and Sample Volume/Bottle......................... 32

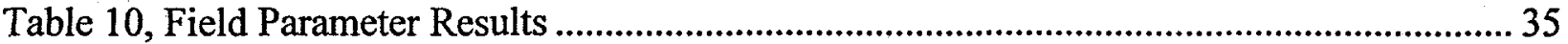

Table 11, TGSC-1 MFV 2-Inch Continuous Siphon Line TCE Analytical Results..................... 37

Table 12, TGSC-1 MFV 2-Inch Upward Leg to 1-1/4 -Inch Crest and Downward Leg

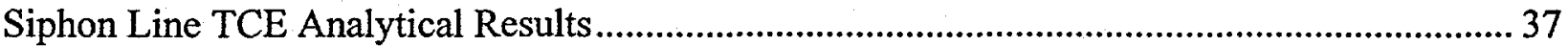

Table 13, TCE Discharge Results from the Siphon Discharge Point (SDP) ............................... 38

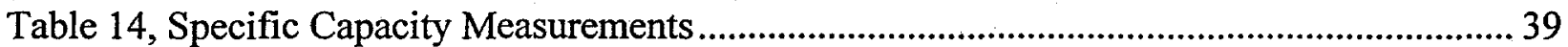

Table 15, Dissolved Gas Average Analytical Results ........................................................ 42

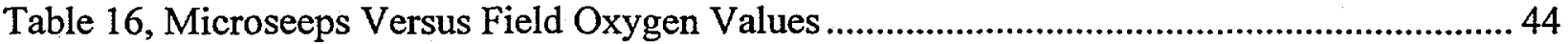

Table 17, Air Chamber / Siphon Crest Gas Average Analytical Results .................................. 46

Table 18, Dissolved Gas in Water, Crest Gas-phase, and Atmospheric Comparison ................. 47

Table 19, Gas Data Analyses: Equilibrium and 11:1 Mixture Comparisons.............................. 48

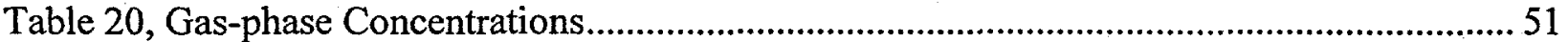

Table 21, TNX Artesian Conditions - P26 Well Cluster............................................................. 58 


\section{LIST OF FIGURES}

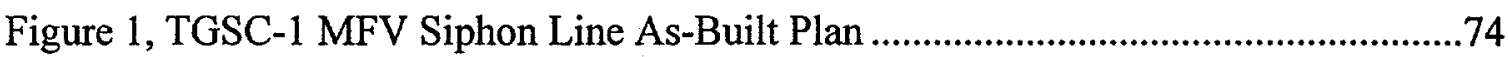

Figure 2, TGSC-1 MFV 2" Continuous Siphon Line As-Built Profile ..................................75

Figure 3, TGSC-1 MFV 2" to 1-1/4" Siphon Line As-Built Profile ...................................76

Figure 4, Crest and Priming System ....................................................................................77

Figure 5, Siphon Line Discharge Sump ............................................................................78

Figure 6, MFV Test 2 Inch Continuous Siphon Line Test Overview.................................79

Figure 7, MFV Test 2 Inch Continuous Siphon Line Head Loss .......................................80

Figure 8, MFV Test 2 Inch Continuous Siphon Line - 4/5/99 Flow Rate Decline.............81

Figure 9, MFV Test 2 Inch Continuous Siphon Line - 4/6/99 Flow Rate Decline.............82

Figure 10, MFV Test 2 Inch Continuous Siphon Line - Temperature Versus

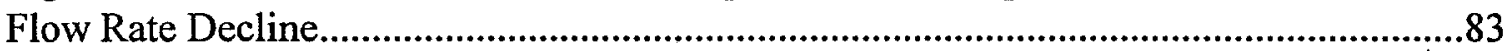

Figure 11, MFV Test 2 Inch to 1-1/4" Siphon Line Test Overview...................................84

Figure 12, MFV Test 2 Inch to 1-1/4" Siphon Line Head Loss ............................................85

Figure 13, MFV Test 2 Inch to 1-1/4" Siphon Line - 4/23/99 Flow Rate Decline .............86

Figure 14, MFV Test 2 Inch to 1-1/4"' Siphon Line - 4/29/99 Flow Rate Decline.............87

Figure 15, MFV Test 2 Inch to 1-1/4" Siphon Line - Temperature Versus

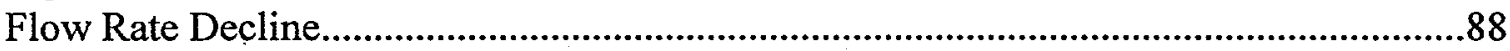

Figure 16, CNP / MFV Test 2 Inch to 1-1/4" Siphon Line - 4/27/99 Flow Rates.............89

Figure 17, CNP / MFV Test 2 Inch to 1-1/4" Siphon Line - 4/27/99 Flow Rates

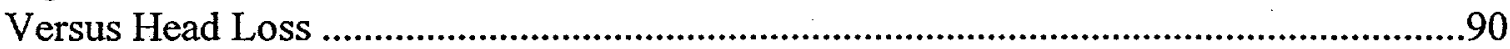

Figure 18, GeoSiphon Cell (Pre-Siphon Treatment Cell Configuration) ............................91

Figure 19, Air Chamber Recharge with Nitrogen-Driven Vacuum Pump .........................92

Figure 20, Air Chamber Recharge with Artesian Well........................................................93

Figure 21, Air Chamber Recharge with Artesian Well Details A \& B.............................94

Figure 22, Solar-powered Vacuum Pump Purge .................................................................95

Figure 23, Continuous Nitrogen-Purge ...........................................................................96

Figure 24, Continuous Water-Driven Eductor, Venturi, or Pump - Artesian Well

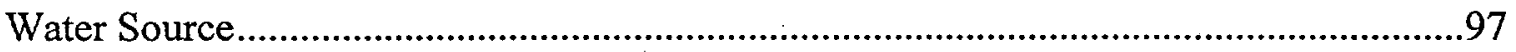

Figure 25, GeoSiphon Cell (Post-Siphon Treatment Cell Configuration)...........................98 


\section{LIST OF APPENDICES}

APPENDIX A, FLOW RATE CALCULATIONS

APPENDIX B, CHLORINATED VOLATILE ORGANIC COMPOUND (CVOC) ANALYTICAL RESULTS

APPENDIX C, SPECIFIC CAPACITY DATA AND CALCULATIONS

APPENDIX D, DISSOLVED GAS AND GAS ANALYTICAL DATA AND

CALCULATIONS:

APPENDIX D-1, ANALYTICAL DATA

APPENDIX D-2, AVERAGED ANALYTICAL DATA

APPENDIX D-3, CALCULATED DISSOLVED GAS SATURATION

CONCENTRATION IN EQUILIBRIUM WITH ATMOSPHERIC AIR

APPENDIX D-4, CALCULATED NORMALIZED EQUILIBRIUM GASPHASE CONCENTRATION IN EQUILIBRIUM WITH THE SIPHON DISCHARGE POINT AVERAGE DISSOLVED GAS CONCENTRATION

APPENDIX E, CREATIVITY COMMITTEE MEETING MINUTES 


\section{LIST OF ACRONYMS}

A-Tox - Ceriodaphnia Dubia, 48-hour, Static, Acute Toxicity Test at an IWC of 33\%

BOS - bottom of screen

cDCE - cis-1,2-dichloroethylene

CNP - Continuous Nitrogen-Purge

CT - tetrachloromethane (carbon tetrachloride)

CVOCs - chlorinated volatile organic compounds

$\mathrm{D}$ - internal pipe diameter in $\mathrm{ft}$

1,1DCE - 1,1-dichloroethylene

DO - dissolved oxygen

US DOE - United States Department of Energy

e/d - relative roughness

Eh - redox or oxidation/reduction potential

EMS - WSRC Environmental Monitoring Section

EPA - Environmental Protection Agency

ERD - WSRC Environmental Restoration Division

EST - WSRC SRTC Environmental Sciences and Technology Department

ETFG - WSRC SRTC Experimental Thermal Fluids Group

ETI - EnviroMetal Technologies, Inc.

FLOW - flow rate monitoring

$\mathrm{ft}$ - feet

$\mathrm{fT}$ - friction factor

$\mathrm{ft}-\mathrm{msl}$ - $\mathrm{ft}$ above mean sea level

$\mathrm{g}$ - acceleration of gravity, $32.2 \mathrm{ft} / \mathrm{s}^{2}$

gpm - gallons per minute

GC-ECD/FID - gas chromatograph with an electron capture detector and a flame ionization detector HDPE - high density polyethylene

IWC - in-stream waste concentration

$\mathrm{K}$ - Henry's law Constant

MFV - Minimum Flushing Velocity

NA - not applicable

ND - not detected

NPDES - National Pollutant Discharge Elimination System

PCE - tetrachloroethylene

PDWS-MCL - Primary Drinking Water Standard Maximum Contaminant Levels

psig - pounds per square inch, gauge

$\mathrm{P} / \mathrm{V}$ - pressure/vacuum monitoring

PVC - polyvinyl chloride

R\&D - research and development

$\mathrm{SC}$ - specific conductance

SCDHEC - South Carolina Department of Health and Environmental Control 


\section{LIST OF ACRONYMS (continued)}

scfm - standard cubic $\mathrm{ft}$ per minute

SDP - siphon discharge point

SES, Inc. - Shealy Environmental Services, Inc.

SOP - Standard Operating Procedure

SQRT - square root

SRS - Savannah River Site

SRTC - Savannah River Technology Center

SS - stainless steel

111,TCA - 1,1,1-trichloroethane

TCE - trichloroethylene

TCM - trichloromethane (chloroform)

tDCE - trans-1,2-dichloroethylene

TGSC-1 - TNX GeoSiphon Cell \#1

TGSC-2 - TNX GeoSiphon Cell \#2

TNX - SRTC Semi-Works Facility

TOC - top of casing

TOR - top of riser

TOS - top of screen

$\mu \mathrm{g} / \mathrm{L}$ - micrograms per liter

US DOE - United States Department of Energy

US EPA - United States Environmental Protection Agency

$\mathrm{V}$ - velocity

VC - chloroethylene (vinyl chloride)

WLEM - water level/elevation monitoring

WSRC - Westinghouse Savannah River Company

YSI - Yellow Springs, Inc. Multi-Parameter Water Quality Monitor 
Left Blank Intentionally 


\subsection{EXECUTIVE SUMMARY}

The TNX Area is a semi-works facility for the Savannah River Technology Center (SRTC), which is located one-quarter mile from the Savannah River at the Savannah River Site (SRS). As the result of TNX operation, groundwater contamination has occurred: The predominant contaminants detected in the flood plain downgradient from TNX are trichloroethylene (TCE) and nitrate.

Treatability studies into the applicability of a groundwater remediation system combining GeoSiphon ${ }^{\mathrm{TM}}$ Cell and zero-valent iron technologies for treatment of the TCE-contaminated groundwater at TNX have been conducted. These treatability studies have been conducted by SRTC under the sponsorship of the Environmental Restoration Department (EPD). GeoSiphon ${ }^{\mathrm{TM}}$ Cells are systems that induce contaminated groundwater flow through permeable treatment media by utilizing a siphon between two points of natural hydraulic head difference. Zero-valent iron degradation of TCE is a reductive dechlorination process, which uses granular cast iron as the reducing agent and produces non-hazardous final reaction products such as ethane, ethene, and chloride ions. Due to the promising aspects of this combination of technologies to treat the TNX-contaminated groundwater, a phased treatability study to evaluate this technology combination has been conducted.

Previous treatability studies demonstrated the following:

- Zero-valent iron effectively treats the TCE-contaminated groundwater

- Continuous, consistent operation of the TNX GeoSiphon ${ }^{\mathrm{TM}}$ Cell (TGSC-1) utilizing a siphon line on an engineered grade with an air chamber at the crest can be maintained

However, a siphon line with a manually operated air chamber does not provide an entirely passive operation, because the air chamber requires periodic water recharging. Therefore the Environmental Restoration Division (ERD) requested SRTC to perform a short-term test to evaluate the potential for minimum flushing velocity (MFV) to maintain passive, continuous, consistent, full siphon flow for the TNX GeoSiphon Cells, without the need to manually recharge an air chamber [Phifer, et al., 1999a]. MFV involves the use of a minimum flushing velocity to transport gas bubbles out the end of the siphon. The results of this study are documented within this report. Results of the MFV testing suggest that under the conditions present at TNX, the MFV mode of operation is not a viable option for the two existing TNX GeoSiphon Cells (TGSC-1 and TGSC-2). The velocity required for maintenance of continuous, consistent, full siphon flow was greater than the velocity produced during the testing. This occurred primarily due to the low head available during the test period and the significant dissolved hydrogen content of the groundwater treated by zero-valent iron.

In conjunction with the MFV testing, a continuous nitrogen-purge (CNP) test was conducted and documented within this report. During the CNP test, gas was continuously removed from the crest of the siphon line using a nitrogen-driven vacuum pump. CNP use is analogous to use of an 
air chamber. However, rather than storing the gasses in a chamber above the siphon line, the gasses are continuously purged from the siphon line. The use of CNP was able to maintain continuous, consistent, full siphon flow. Operation of a siphon line with CNP is also not entirely passive, because a continuous source of nitrogen, which requires periodic change out, is required to drive the vacuum pump.

Based upon the treatability studies to date and the desire by ERD for as passive a system as possible for operation of the existing TNX GeoSiphon Cells, the following are recommended:

- Laboratory-scale testing to evaluate the ability of a solar-powered, vacuum pump to passively recharge an air chamber should be performed, as suggested by the SRTC Experimental Thermal Fluids Group (ETFG).

- If the solar-powered, vacuum pump laboratory system proves successful, installation of the system in the field should be performed for a long-term field-scale demonstration. This would demonstrate long-term, continuous, consistent operation utilizing the solarpowered, vacuum pump and allow the evaluation of the siphon flows under various conditions of head. Additionally it would allow the evaluation of possible iron precipitation fouling and iron deactivation through the determination of the specific capacity, the TCE discharge concentration, and the TCE first order rate constant.

- Concurrent with the solar-powered, vacuum pump laboratory scale testing, design, installation, and long-term testing of a manually recharged air chamber GeoSiphon system for operation of the existing two cells should be performed. The manual air chamber system should be designed to be compatible with the solar-powered vacuum pump option. This would allow installation of the field solar-powered, vacuum pump system onto the then existing manual air chamber system, once the solar-powered, vacuum pump system was laboratory proven, assuming it is proven. Long-term operation of the manual air chamber system would demonstrate long-term continuous, consistent operation and allow the evaluation of the siphon flows, gas generation rates, and gas composition under various conditions of head, temperature, etc. Additionally it would allow the evaluation of possible iron precipitation fouling and iron deactivation through the determination of the specific capacity, the TCE discharge concentration, and the TCE first order rate constant. Such a concurrent approach would expedite longterm field testing of the TNX GeoSiphon system, while allowing evaluation of two operational modes. 


\subsection{INTRODUCTION}

\subsection{TNX GROUNDWATER}

The TNX Area is a semi-works (pilot-scale test) facility for the Savannah River Technology Center (SRTC), which is located one-quarter mile from the Savannah River at the Savannah River Site (SRS). TNX is on a terrace above the Savannah River. A portion of the Savannah River flood plain lies immediately west of the TNX Area. Groundwater at TNX can be divided into two main aquifer systems, a shallow and deep aquifer system. The shallow system can be further subdivided into a water table aquifer ( 35 to $40 \mathrm{ft}$ thick) and a deeper semi-confined aquifer overlain by a clayey silt aquitard. The hydraulic gradients are such that groundwater flows progressively from the deeper aquifers to the shallower aquifers and finally to the Savannah River.

As the result of TNX operation, groundwater contamination of the water table aquifer (TNX Groundwater RCRA/CERCLA Operable Unit) has occurred. Consistent with the groundwater flow pattern between aquifers, no contamination has been detected in the semi-confined or deep aquifers. The predominant contaminants detected in the flood plain downgradient from TNX are TCE and nitrate; however carbon tetrachloride (CT), tetrachloroethylene (PCE), cis-1,2dichloroethylene (cDCE), and gross alpha radioactivity may also exist at detectable concentrations within the TNX flood plain [Phifer, et al., 1998].

\subsection{GEOSIPHON ${ }^{\mathrm{TM}}$ CELL AND ZERO-VALENT IRON TECHNOLOGIES}

Studies into the applicability of a groundwater remediation system combining GeoSiphon ${ }^{\mathrm{TM}}$ Cell and zero-valent iron technologies (i.e., zero-valent, iron-enhanced, abiotic degradation of chlorinated volatile organic compounds (CVOCs)) for treatment of the TCE-contaminated groundwater at TNX have been conducted by WSRC. GeoSiphon ${ }^{\mathrm{TM}}$ Cells are systems that induce contaminated groundwater flow through permeable treatment media by utilizing the natural hydraulic head difference between two points. The induced flow is produced by the use of a siphon between the points of natural head difference. The groundwater is treated as it passes through the permeable treatment media. Zero-valent iron degradation of CVOCs is essentially a reductive dechlorination process, which uses granular cast iron as the reducing agent and produces final reaction products such as ethane, ethene, and chloride ions in the degradation of TCE. Due to the promising aspects of this combination of technologies to treat the TNXcontaminated groundwater, a phased approach to evaluate this technology combination has been conducted. The phases conducted to date are summarized below.

\subsection{ZERO-VALENT IRON LABORATORY STUDY}

A laboratory study into the applicability of zero-valent, iron-enhanced, abiotic degradation of CVOCs to the TNX-contaminated groundwater was conducted. Results from the 1996 laboratory study demonstrated that zero-valent iron can treat the TNX TCE-contaminated 
groundwater to below the Primary Drinking Water Standard Maximum Contaminant Levels

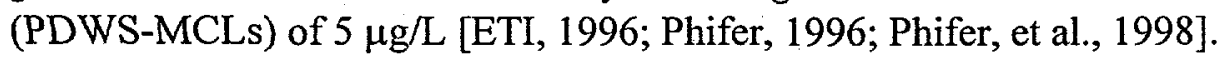

\subsection{TNX GEOSIPHON CELL (TGSC-1)}

The GeoSiphon Cell was conceived as an alternative to pump and treat systems, funnel and gate systems, and continuous permeable wall treatment systems for the application of zero-valent iron, pursuant to the FY 1996 laboratory study. The first TNX GeoSiphon Cell, TGSC-1, was installed within the TNX flood plain in July 1997. TGSC-1 was built in a pre-siphon treatment cell configuration (i.e., treatment occurs prior to water transport within the siphon). The cell is essentially a large diameter well, containing granular cast iron (the treatment media) in place of gravel pack. Contaminated groundwater flow through the granular cast iron in the treatment cell is induced by use of a siphon from the cell to the Savannah River. The flow is induced by the natural hydraulic head difference between the cell and the Savannah River. The granular cast iron reduces the TCE to ethane, ethene, and chloride ions. The treated water is subsequently discharged through the X-19 outfall to the Savannah River [ETI, 1996; Phifer, 1996; Phifer, et al., 1998].

\subsubsection{Phase I Testing}

Phase I testing of TGSC-1 was conducted from August 5, 1997, to December 16, 1997. Phase I testing consisted of pumped flow from the cell to the TNX National Pollutant Discharge Elimination System (NPDES) X-08 outfall and the creation of steady-state conditions to determine the in situ field treatment capacity of the cell. Results from Phase I testing indicated that the degradation of TCE is the limiting compound to treatment below the PDWS-MCLs within the TNX GeoSiphon Cell. The data also indicated that a maximum flow rate of between $7.8 \mathrm{gpm}$ and $8.3 \mathrm{gpm}$ of groundwater contaminated with 200 to $250 \mu \mathrm{g} / \mathrm{L}$ TCE could be treated while maintaining the average discharge TCE concentration below $5 \mu \mathrm{g} / \mathrm{L}$. The second TNX GeoSiphon Cell, TGSC-2, was installed within the TNX flood plain in September 1998 [Phifer, et al., 1998; Nichols, et al., 1999].

\subsubsection{Phase II Single-Cell Testing}

Phase II single-cell testing of TGSC-1 was conducted from June 18, 1998, to November 13, 1998. The testing was conducted using siphon flow from the cell to the Savannah River or the X-08 outfall ditch, which flows into the Savannah River. This phase was designed to determine siphon flow rates and demonstrate the overall concept and functionality of the technology as applied at TNX. Four different siphon line configurations and a one-day MFV test were conducted during this phase of testing. Examination of the first three siphon line configurations, revealed that dissolved gasses in the treated water were de-gassing in the siphon line, becoming entrapped at localized high points in the line. Accumulation of the gas in the siphon line resulted in flow reductions and the eventual operational stoppage. The addition of an air chamber and placement of the siphon line on an engineered grade improved operations. The fourth siphon line configuration was shortened to discharge into the X-08 outfall ditch rather than the Savannah River to place the line entirely on an engineered grade with an air chamber at the crest. This 
configuration resulted in continuous, consistent operation with flow rates consistent with calculated values. Re-priming was not required; however, it did require periodic water recharging of the air chamber. The fourth siphon line configuration maintained full siphon line flow by removal of gas bubbles from its entire length.

The use of Minimum Flushing Velocity (MFV) to maintain full flow in the siphon line was evaluated during a one-day test utilizing the fourth siphon line configuration without the air chamber. MFV is the minimum velocity required to transport air bubbles out the end of the siphon line. Testing revealed that for MFV to be a viable method for removing gas from the siphon, line discontinuities and localized high points must be eliminated. Line discontinuities and localized high points promote bubble accumulation, agglomeration, and entrapment. Based upon the results of the one-day MFV test, the following recommendations for testing the effectiveness of MFV were made:

- MFV could be employed using one continuous pipe without fittings placed on an engineered grade with one crest.

- Alternately, MFV could be employed using one continuous larger diameter pipe on the upward leg of the siphon line followed by a smaller diameter pipe utilized for the crest and downward leg of the siphon line, without fittings that promote bubble accumulation and agglomeration. This second MFV alternative has the potential to create higher flow rates and velocities than the first one. However, the flows would still be less than that possible with the use of an air chamber.

[Phifer, et al., 1999a]

\subsection{PHASE II MINIMUM FLUSHING VELOCITY TEST OBJECTIVE}

During the Phase II single-cell testing, continuous, consistent, full siphon flow was obtained with TGSC-1 utilizing a siphon line on an engineered grade with an air chamber at the crest. A siphon line with a manually operated air chamber does not provide an entirely passive operation because periodic air chamber water recharging events are required.

Due to the desire by ERD for as passive a system as possible, ERD requested that SRTC perform a short-term MFV test. The Phase II MFV testing of TGSC-1 was conducted during April 1999 to determine the feasibility of utilizing $\mathrm{MFV}$ as the sole means of maintaining continuous, consistent, full siphon flow between TGSC-1 and the siphon discharge point. This activity was classified as an on-site technical baseline research and development (R\&D) activity. This activity was performed and documented as outlined in WSRC-TR-99-00039, Task Technical and Quality Assurance Plan - TNX GeoSiphon Cell Phase II Minimum Flushing Velocity Test, dated February 18, 1999 [Phifer and Nichols, 1999]. 
The April 1999 MFV tests, performed utilizing the first TNX GeoSiphon Cell, TGSC-1, are detailed within this report. The following information concerning the MFV tests, operation options for the existing TNX GeoSiphon Cells, and future installations is provided within this report:

- Summaries of previous studies and tests associated with the TNX GeoSiphon Cells

- Background information concerning siphons, the potential for MFV use at TNX, and test permitting

- MFV hydraulic test description and results

- MFV test sampling and analysis description and results

- Operation options for the existing cells

- Alternate GeoSiphon Cell configuration

- Conclusions and recommendations 


\subsection{BACKGROUND}

Refer to the TNX GeoSiphon Cell (TGSC-1) Phase I Deployment / Demonstration Final Report (U), [Phifer, et al., 1998], for the following background information not included in this report:

- TNX Area groundwater contamination description

- TNX zero-valent iron laboratory study summary

- Phase I permitting activities overview

- TNX GeoSiphon Cell (TGSC-1) installation and as-built conditions

- Detailed Phase I treatability test results

- Phase I pump test results

- Phase I preliminary modeling results

Refer to the TNX GeoSiphon Cell (TGSC-1) Phase II Single-Cell Deployment / Demonstration Final Report (U), [Phifer, et al., 1999a], for the following additional background information not included in this report:

- GeoSiphon cell concept overview

- Zero-valent, iron-enhanced, abiotic degradation overview

- Phase II single-cell, permitting activities overview

- Detailed Phase II single-cell siphon hydraulics test results

- Detailed Savannah River Stage data

- Detailed Phase II single-cell sampling and analysis results

\subsection{SIPHON TECHNOLOGY OVERVIEW}

A siphon is a closed conduit that conveys liquid from a point of higher hydraulic head to one of lower head after raising it to a higher intermediate elevation, at sub-atmospheric conditions (negative gauge pressures), without external power input. A siphon has a maximum theoretical lift of 34-ft (equivalent to atmospheric pressure). However, it has a maximum practical lift of 25 $\mathrm{ft}$ due to the vapor pressure of water and friction head loss [Gibson, 1961; Phifer, et al., 1998; Phifer, et al., 1999a].

Siphons require priming (initial filling of line) to initiate flow. This can be accomplished by gravity filling from the high point in the line (crest) with the inlet and outlet valved off or using a vacuum pump at the crest with the inlet and outlet submerged and opened. After priming, the siphon will convey liquid from the point of higher hydraulic head to the one of lower head so long as the head differential is maintained and the prime is not lost [Gibson, 1961; Loitz, et al., 1990; Phifer, et al., 1998; Phifer, et al., 1999a]. 
Accumulation of air can break the siphon. However, this can be avoided by employing the following means:

- Use of submerged inlets and outlets to prevent air from being drawn into the siphon. (Where flow is sufficient to maintain full pipe flow on its own, a submerged outlet is not required; however it is recommended.)

- Maintenance of full flow in the siphon by one or a combination of the following methods:

- Maintenance of the MFV required to transport gasses that have de-gassed from the liquid out the end of the siphon

- Use of any other method to remove from the siphon gasses that have de-gassed from the liquid (such as the use of air chambers at the siphon crest)

The following are empirical equations to determine the required MFV for the transport of "large" air bubbles out the end of the siphon as determined from laboratory and large-scale tests, respectively, as reported in the literature:

$$
\begin{aligned}
& \text { Equation 1) } \\
& \text { Equation 2) }
\end{aligned} \quad \begin{aligned}
& \mathrm{V}=0.31(\mathrm{SQRT}(\mathrm{gD})) \text { (laboratory-scale empirical equation) } \\
& \mathrm{V}=0.58(\mathrm{SQRT}(\mathrm{gD})) \text { (large-scale empirical equation) } \\
& \mathrm{V}=\text { velocity in } \mathrm{ft} / \mathrm{s} ; \mathrm{g}=32.2 \mathrm{ft} / \mathrm{s}^{2} ; \mathrm{D}=\text { internal pipe diameter in } \mathrm{ft}
\end{aligned}
$$

These equations show the empirical velocity relationships used to determine the minimum velocity required to transport "large" air bubbles out the end of the siphon. These relationships are based upon the specific conditions of the test setups and do not take into account bubble size (i.e., length and diameter of bubbles), siphon line grades, or the resulting buoyancy of the bubbles, all of which impact bubble transport. Equation 2 is more conservative than equation 1 [Gibson, 1961; Mathur, 1990].

In cases where the MFV is not effective in removing bubbles, an air chamber is an option that can be used to remove bubbles from the line and maintain the prime. An air chamber is essentially a high point accumulation for gasses that de-gas from the water within the siphon line. Air chambers are located above the siphon line at the line high point (crest) and are connected to the siphon line. The air chamber is initially filled with water during priming of the line. As the system operates and de-gassing occurs, the buoyancy of the gas and/or the flow of water transport the bubbles to the air chamber. The gas accumulates and displaces the water in the air chamber, thus maintaining the prime. The gas in the air chamber must be evacuated and replaced with water on a periodic basis to maintain the siphon line free of accumulated gas. The air chamber can be sized to minimize the frequency of recharging with water [Gibson, 1961; Mathur, 1990].

Gas solubility in water varies directly with the partial pressure of the gas in contact with the water and indirectly with temperature [Manahan, 1991]. Therefore, de-gassing within a siphon line increases with increasing vacuum and temperature. When the siphon line height and internal 
temperature is minimized, so is de-gassing.

\subsection{MINIMUM FLUSHING VELOCITY PRELIMINARY EVALUATION}

Continuous, consistent, full siphon flow was obtained with TGSC-1 utilizing a siphon line on an engineered grade with an air chamber at the crest. This was a passive operation between air chamber water recharging events. However the air chamber did require periodic water recharging. The use of MFV offers the potential for passive operation, without the need to manually recharge an air chamber. While continuous, consistent, full siphon flow was not obtained utilizing MFV during the Phase II single-cell testing, the testing revealed that line discontinuities and localized high points must be eliminated to make MFV potentially viable [Phifer, et al., 1999a]. Additional detail is provided in Section 2.0.

Prior to conducting Phase II MFV testing, calculations were performed to evaluate the potential to maintain continuous, consistent, full siphon flow in the TNX GeoSiphon Cell siphon line utilizing MFV. Table 1 summarizes the results. The calculations assumed that single-phase flow equations could adequately represent the flow as they did with usage of an air chamber and were based upon the following water level/elevation conditions (WLEM):

- A Savannah River water elevation below the discharge point elevation (i.e., the water elevation at the discharge point not impacted by the Savannah River water elevation)

- The water elevation of TGSC-1 approximated by the average water elevation at monitoring well TNX-11D of $93.73 \mathrm{ft}-\mathrm{msl}$ (TNX-11D is approximately $50.2 \mathrm{ft}$ sidegradient of TGSC-1) [Phifer, et al., 1999a]

Table 1 indicates that, under average groundwater levels, it may be possible to maintain continuous, consistent, full siphon flow of the TGSC-1 siphon line utilizing an MFV where the calculated velocity is greater than the MFV in the downward leg of the line. Table 1 indicates that a 2-inch upward leg to the siphon crest, followed by either a 1-, 1-1/4-, or 1-1/2-inch crest and downward leg to the discharge point, should be capable of removing bubbles from the line. Table 1 also indicates that a continuous 2 -inch line will not produce a velocity greater than the MFV Equation 2. However, Table 1 also indicates that a continuous 2-inch line should produce a velocity greater than the less conservative MFV Equation 1 . This indicated that the continuous 2 -inch line might work since its velocity is within the range of the two empirical values.

The flow rate through the cell and siphon line will vary according to the difference between the water level elevation in the cell and the water level elevation at the siphon discharge point (SDP). Water level elevations in the cell will vary with precipitation, evapotranspiration, and natural drainage of the shallow water table aquifer into the Savannah River. The water level elevation at the discharge point will be relatively constant most of the time. Occasionally $(\sim 27$ percent of the time over a ten-year period) the Savannah River elevation rises above the elevation of the planned siphon line discharge point of approximately $88.82 \mathrm{ft}-\mathrm{msl}$. Water level elevation variations at either the cell and/or the discharge point will produce variations in the flow rate and subsequently in the velocity within the siphon line. Elevated water levels at the discharge point may significantly decrease the flow rate and velocity through the siphon line if a corresponding 
rise in the cell water level does not occur. This could reduce the ability to maintain full siphon flow through the use of MFV under these lower head differential conditions [Phifer, et al., 1999a].

Because entirely passive, continuous, consistent, full siphon flow in the TGSC-1 siphon line might be maintained by MFV, without the need to manually recharge an air chamber, ERD requested that SRTC perform a short-term MFV test.

Table 1

Calculated Flows and Velocities versus Minimum Flushing Velocity

\begin{tabular}{|c|c|c|c|c|c|c|}
\hline $\begin{array}{l}\text { GeoSiphon } \\
\text { Cell }\end{array}$ & $\begin{array}{l}\text { Pipe } \\
\text { Diameter } \\
\text { (in) }\end{array}$ & $\begin{array}{l}\text { Pipe } \\
\text { Length } \\
\text { (ft) }\end{array}$ & $\begin{array}{l}\text { Calculated } \\
\text { Flow }^{5} \\
(\mathrm{gpm})\end{array}$ & $\begin{array}{l}\text { Calculated } \\
\text { Velocity } \\
(\mathrm{ft} / \mathrm{s})\end{array}$ & $\begin{array}{l}\text { Equation } 2 \\
\text { Calculated } \\
\text { Required } \\
\text { Minimum } \\
\text { Flushing } \\
\text { Velocity }^{6} \\
(\mathrm{ft} / \mathrm{s})\end{array}$ & $\begin{array}{l}\text { Equation 1 } \\
\text { Calculated } \\
\text { Required } \\
\text { Minimum } \\
\text { Flushing } \\
\text { Velocity }{ }^{7} \\
(\mathrm{ft} / \mathrm{s})\end{array}$ \\
\hline TGSC-1 & $2^{2}$ & 279 & 9.5 & 0.91 & 1.37 & 0.73 \\
\hline TGSC-1 & $\begin{array}{l}2^{3} \\
1-1 / 24\end{array}$ & $\begin{array}{l}246 \\
33\end{array}$ & $\begin{array}{l}8.98 \\
8.98\end{array}$ & $\begin{array}{l}0.859 \\
1.63\end{array}$ & $\begin{array}{l}1.37 \\
1.16\end{array}$ & $\begin{array}{l}0.73 \\
0.62\end{array}$ \\
\hline TGSC-1 & $1-1 / 4^{4}$ & $\begin{array}{l}246 \\
33\end{array}$ & $\begin{array}{l}8.12 \\
8.12\end{array}$ & $\begin{array}{l}0.777 \\
2.13\end{array}$ & $\begin{array}{l}1.37 \\
1.06\end{array}$ & $\begin{array}{l}0.73 \\
0.57\end{array}$ \\
\hline TGSC-1 & $\begin{array}{l}2^{3} \\
1^{4}\end{array}$ & $\begin{array}{l}246 \\
33\end{array}$ & $\begin{array}{l}6.18 \\
6.18\end{array}$ & $\begin{array}{l}0.59 \\
2.55\end{array}$ & $\begin{array}{l}1.37 \\
0.95\end{array}$ & $\begin{array}{l}0.73 \\
0.51\end{array}$ \\
\hline
\end{tabular}

${ }^{1}$ For this calculation the 2-inch diameter pipe was assumed to be HDPE with an 2.067 inch $(0.1723 \mathrm{ft})$ inside diameter and the 1-, 1-1/4-, and 1-1/2-inch diameter pipes were assumed to be tubing with inside diameters equal to the nominal size

${ }^{2}$ Upward leg, crest, and downward leg of siphon line

${ }^{3}$ Upward leg of siphon line

${ }^{4}$ Crest and downward leg of siphon line

${ }^{5}$ See Calculation Number GCD-6 [Phifer, 1999a]

${ }^{6}$ Equation 2 Minimum Flushing Velocity $(\mathrm{MFV})=0.58(\mathrm{SQRT}(\mathrm{gD})) ; \mathrm{g}=32.2 \mathrm{ft} / \mathrm{s}^{2} ; \mathrm{D}=$ inside diameter in $\mathrm{ft}$ (large scale empirical equation)

${ }^{7}$ Equation 1 Minimum Flushing Velocity $(\mathrm{MFV})=0.31(\mathrm{SQRT}(\mathrm{gD})) ; \mathrm{g}=32.2 \mathrm{ft} / \mathrm{s}^{2} ; \mathrm{D}=$ inside diameter in $\mathrm{ft}$ (laboratory-scale empirical equation) 


\subsection{PHASE II MINIMUM FLUSHING VELOCITY PERMITTING ACTIVITIES OVERVIEW}

The following is a correspondence summary of the SCDHEC and US EPA permitting performed for the TNX GeoSiphon Cell Phase II MFV demonstration:

- Letter, Byron M. Amick to John W. Cook, dated October 28, 1998, incorporated the SRS/TNX GeoSiphon Cell Phase II Siphon Line Reconfiguration in Construction Permit No. 18,234-IW [Lintern, 1998].

- Partial Permit to Operate the SRS/TNX GeoSiphon Cell Phase II Siphon Line Reconfiguration in accordance with Construction Permit No. 18,234-IW issued March 23, 1999, by Betsy Malpass [Lintern, 1999].

Refer to the TNX GeoSiphon Cell (TGSC-1) Phase I Deployment / Demonstration Final Report (U), [Phifer, et al., 1998], and to the TNX GeoSiphon Cell (TGSC-1) Phase II Single Deployment / Demonstration Final Report (U), [Phifer, et al., 1999a] for the SCDHEC and US EPA permitting performed for those phases of the demonstration. 
Left Blank Intentionally 


\subsection{MINIMUM FLUSHING VELOCITY HYDRAULIC TESTS}

\subsection{MINIMUM FLUSHING VELOCITY HYDRAULIC TEST DESIGN}

TNX GeoSiphon Cell TGSC-1 was utilized to conduct the Phase II MFV test. The test was conducted to determine the adequacy of MFV in maintaining continuous, consistent, full siphon flow from TGSC-1 to the X-08 outfall ditch discharge point. Table 2 lists the two siphon line configurations tested. Figures 1,2, and 3 provide the TGSC-1 siphon line plan and profiles of the configurations tested.

Table 2

Minimum Flushing Velocity Test Siphon Line Configurations

\begin{tabular}{|c|c|c|}
\hline Test \# & Siphon Line Configuration & Figures \\
\hline 1 & Continuous 2" & $1 \& 2$ \\
\hline 2 & $\begin{array}{c}\text { 2" upward leg to 1-1/4" crest and } \\
\text { downward leg }\end{array}$ & $1 \& 3$ \\
\hline
\end{tabular}

Notes: The 2" line was 2 " high density polyethylene (HDPE) with an inside diameter of 2.067" $\left(0.1723^{\prime}\right)$ and the $1-1 / 4$ " line was 1-1/4" HDPE with an inside diameter of $1.380^{\prime \prime}\left(0.1150^{\prime}\right)$

The following parameters were monitored:

- Water level/elevation

- Flow rate

- Siphon line pressure/vacuum

Water level/elevation and flow rate data were collected as baseline data per the Task Technical and Quality Assurance Plan - TNX GeoSiphon Cell Phase II Minimum Flushing Velocity Test, WSRC-TR-99-00039 [Phifer and Nichols, 1999]. The siphon line pressure/vacuum data were collected as non-baseline data per the same plan. Table 3 lists the location and details of each location that was monitored and the parameters monitored.

Due to Well TNX-9D's significant side-gradient distance from TGSC-1 (360 ft), the short duration of the MFV tests, and the low average MFV test flow rates, TNX-9D should not have been hydraulically impacted by operation of TGSC-1. Therefore, the water level elevations measured at TNX-9D reflect the natural water table fluctuations during the tests. 
Table 3

Monitoring Location, Details, and Parameters

\begin{tabular}{|c|c|c|c|c|c|c|c|c|}
\hline \multirow[t]{2}{*}{ Location } & \multirow{2}{*}{$\begin{array}{c}\text { Coordinates } \\
\text { (ft) }\end{array}$} & \multicolumn{4}{|c|}{ Elevation (ft-msl) } & \multirow{2}{*}{$\begin{array}{l}\text { Casing } \\
\text { Diameter }\end{array}$} & \multirow{2}{*}{$\begin{array}{c}\text { Distance } \\
\text { to Cell }\end{array}$} & \multirow{2}{*}{$\begin{array}{l}\text { Monitoring } \\
\text { Parameters }\end{array}$} \\
\hline & & TOR & TOC & TOS & BOS & & & \\
\hline $\begin{array}{l}\text { GeoSiphon } \\
\text { Cell } \\
\text { (TGSC-1) }\end{array}$ & $\begin{array}{l}\text { N71150.24 } \\
\text { E16176.21 }\end{array}$ & - & 98.13 & 90.9 & 76.9 & $12 "$ & $0^{2}$ & WLEM \\
\hline $\begin{array}{c}\text { Well } \\
\text { TCM-2 }\end{array}$ & $\begin{array}{l}\text { N71142.43 } \\
\text { E16199.68 }\end{array}$ & - & 99.02 & 94.02 & 74.02 & $4 "$ & $\begin{array}{c}24.7^{\prime} \\
\text { upgradient }\end{array}$ & WLEM \\
\hline $\begin{array}{c}\text { Well } \\
\text { TCM-4 }\end{array}$ & $\begin{array}{l}\text { N71141.4 } \\
\text { E16174.9 }\end{array}$ & - & 99.49 & 94.6 & 79.6 & $2 "$ & $\begin{array}{c}8.9^{\prime} \\
\text { side } \\
\text { gradient }\end{array}$ & WLEM \\
\hline $\begin{array}{c}\text { Well } \\
\text { TNX-9D }\end{array}$ & $\begin{array}{l}\text { N70791.4 } \\
\text { E16145.8 }\end{array}$ & 101.9 & 101.7 & 95.4 & 75.4 & $4 "$ & $\begin{array}{c}360.2^{\prime} \\
\text { side } \\
\text { gradient }\end{array}$ & WLEM \\
\hline $\begin{array}{l}\text { 2" Siphon } \\
\text { Crest }\end{array}$ & $\begin{array}{l}\sim \mathrm{N} 71311 \\
\sim \mathrm{E} 16010\end{array}$ & - & 100.931 & - & - & $\begin{array}{c}2 " \\
\text { HDPE } \\
\text { pipe }^{2}\end{array}$ & $\begin{array}{l}\sim 232^{\prime} \\
\text { down } \\
\text { stream }\end{array}$ & $\mathrm{P} / \mathrm{V}$ \\
\hline $\begin{array}{c}\text { 1-1/4" Siphon } \\
\text { Crest }\end{array}$ & $\begin{array}{l}\sim \mathrm{N} 71311 \\
\sim \mathrm{E} 16010\end{array}$ & - & 105.96 & - & - & $\begin{array}{l}1-1 / 4^{\prime \prime} \\
\text { HDPE } \\
\text { pipe }^{2}\end{array}$ & $\begin{array}{l}\sim 234^{\prime} \\
\text { down } \\
\text { stream }\end{array}$ & $\mathrm{P} / \mathrm{V}$ \\
\hline $\begin{array}{c}\text { Siphon } \\
\text { Discharge } \\
\text { Point (SDP) }\end{array}$ & $\begin{array}{c}\sim \mathrm{N} 71320.3 \\
\sim \mathrm{E} 15980.6 \\
(\mathrm{TBD})\end{array}$ & - & 92.031 & - & - & $12 "$ & $\begin{array}{c}\sim 259.2^{\prime} \\
\text { down } \\
\text { stream }\end{array}$ & $\begin{array}{l}\text { WLEM \& } \\
\text { FLOW }\end{array}$ \\
\hline
\end{tabular}

Notes: TOR = top of riser; TOC = top of casing; TOS = top of screen; BOS = bottom of screen; $\mathrm{WLEM}=$ water level/elevation monitoring; FLOW = flow rate monitoring; $\mathrm{P} / \mathrm{V}=$ pressure/vacuum monitoring

${ }^{1}$ Top of piping elevation rather than top of casing elevation

${ }^{2}$ Pipe diameter rather than casing diameter

\subsection{MINIMUM FLUSHING VELOCITY HYDRAULIC TEST RESULTS}

\subsubsection{Continuous 2-Inch MFV Siphon Line}

\subsubsection{Continuous 2-Inch MFV Siphon Line Installation}

The continuous 2-inch high density polyethylene (HDPE) MFV siphon line was installed from the TNX GeoSiphon Cell (TGSC-1) to the X-08 outfall ditch as shown in Figures 1 (plan), 2 (profile), 4 (crest and priming system), and 5 (discharge sump). The siphon line consisted of the following, in order, from TGSC-1 to the discharge point in the X-08 outfall ditch:

- Approximately 15-foot long, 2-inch diameter, stainless steel riser out of TGSC-1 (see Figure 2)

- Approximately $230 \mathrm{ft}$ of 2 -inch diameter HDPE pipe (inside diameter $=2.067$ inches) at 
an average upward slope of $2.45 \%$ from TGSC-1 to the crest (see Figure 2)

- A tapping saddle clamped to the 2-inch HDPE pipe for installation of a vacuum gauge prior to the crest

- An HDPE saddle joint welded to the 2-inch diameter HDPE at the crest with a $1 / 2$-inch diameter, carbon-steel pipe and ball valve for connection to the priming system (see Figure 4)

- A priming system connected to the $1 / 2$-inch diameter, carbon-steel pipe at the crest, which utilized a nitrogen-driven, venturi-type, vacuum pump to pull the prime (see Figure 4)

- Approximately $24 \mathrm{ft}$ of 2-inch diameter HDPE pipe at an average downward slope of $60 \%$ from the crest to the discharge point (see Figure 2)

The siphon line discharged into a 12-inch diameter polyvinyl chloride (PVC) sump located in the X-08 outfall ditch to maintain a submerged siphon line outlet (see Figure 5). Table 4 provides the as-built coordinates, distances, elevations, lengths, and slopes of this configuration. To minimize discontinuities in the inside diameter of the siphon line, which could promote bubble accumulation, agglomeration, and entrapment, one continuous length of 2-inch diameter HDPE pipe was utilized from TGSC-1 to the siphon discharge sump. Only three fittings were utilized within the siphon line:

- A Dresser model 360 water repair clamp to connect the 2-inch diameter, stainless steel riser (within TGSC-1) and the 2-inch diameter, HDPE pipe (silicon caulk was utilized to ensure a positive seal between the pipes and clamp)

- A tapping saddle clamped to the 2-inch HDPE pipe for installation of a vacuum gauge prior to the crest

- An HDPE saddle joint welded at the crest of the 2-inch HDPE pipe, with a $1 / 2$-inch carbon-steel pipe and ball valve for connection to the priming system

To eliminate localized high points, the entire siphon line was placed on an engineered grade, with the crest, from which the prime was pulled, as the only high point in the line. A significant portion of the line was installed above grade, which was subject to thermal expansion. The HDPE line was installed so that the designated crest would remain the highest point in the line even with linear expansion of the HDPE due to temperature. Thermal expansion would be minimized with installation of the siphon line entirely underground.

To ensure that no leaks existed in the siphon line, a hydrostatic leak test at 15 psig was conducted on the 2-inch HDPE line (the 2-inch stainless steel riser and Dresser repair clamp were disconnected from the HDPE line and were therefore not tested). No leaks were detected during the hydrostatic leak test. A vacuum leak test was not performed. 
Table 4

TGSC-1 MFV 2-Inch Continuous Siphon Line As-Built Details

\begin{tabular}{|c|c|c|c|c|c|c|}
\hline \multirow[b]{2}{*}{ Location } & \multicolumn{2}{|c|}{ Coordinates } & \multirow{2}{*}{$\begin{array}{l}\text { Cumulative } \\
\text { Horizontal } \\
\text { Distance } \\
\text { from TGSC-1 } \\
\text { (ft) }\end{array}$} & \multirow{2}{*}{$\begin{array}{l}\text { Bottom of } \\
\text { Siphon } \\
\text { Elevation } \\
\text { (ft-msl) }\end{array}$} & \multirow{2}{*}{$\begin{array}{l}\text { Cumulative } \\
\text { Siphon } \\
\text { Length } \\
\text { (ft) }\end{array}$} & \multirow{2}{*}{$\begin{array}{c}\text { Siphon } \\
\text { Slope } \\
(\%)\end{array}$} \\
\hline & $\begin{array}{l}\text { East } \\
(\mathrm{ft})\end{array}$ & $\begin{array}{c}\text { North } \\
\text { (ft) }\end{array}$ & & & & \\
\hline Siphon Line Inlet & 16176.21 & 71150.24 & 0.00 & 82.00 & 0.00 & N \\
\hline Top Siphon Line at TGSC-1 & 16176.21 & 71150.24 & 0.00 & 95.41 & 13.41 & up \\
\hline Edge 12" casing at slot & 16175.80 & 71150.58 & 0.53 & 95.41 & 13.94 & elbow \\
\hline End box & 16171.57 & 71154.13 & 6.05 & 95.64 & 19.47 & 4.07 \\
\hline Ditch (within 3" pipe sleeve) & 16162.75 & 71161.61 & 17.62 & 95.96 & 31.04 & 2.81 \\
\hline Ditch (within 3" pipe sleeve) & 16153.82 & 71169.30 & 29.40 & 96.28 & 42.83 & 2.72 \\
\hline Ditch (within 3" pipe sleeve) & 16145.68 & 71176.16 & 40.05 & 96.55 & 53.48 & 2.54 \\
\hline Ditch (within 3" pipe sleeve) & 16137.92 & 71182.76 & 50.24 & 96.75 & 63.67 & 1.96 \\
\hline Ditch (within 3" pipe sleeve) & 16131.22 & 71188.37 & 58.98 & 96.94 & 72.41 & 2.17 \\
\hline Ditch (within 3" pipe sleeve) & 16119.01 & 71198.68 & 74.96 & 97.40 & 88.39 & 2.88 \\
\hline Support \#1 & 16101.14 & 71213.81 & 98.37 & 98.03 & 111.82 & 2.69 \\
\hline Support \#2 & 16090.94 & 71222.47 & 111.75 & 98.40 & 125.20 & 2.77 \\
\hline Support \#3 & 16081.12 & 71231.01 & 124.77 & 98.80 & 138.22 & 3.07 \\
\hline Support \#8 & 16078.63 & 71232.91 & 127.90 & 98.90 & 141.36 & 3.19 \\
\hline Support \#9 & 16068.33 & 71244.52 & 143.42 & 99.14 & 156.88 & 1.55 \\
\hline Support \#10 & 16055.14 & 71259.45 & 163.34 & 99.53 & 176.80 & 1.96 \\
\hline Support \#11 & 16045.32 & 71270.60 & 178.20 & 99.83 & 191.66 & 2.02 \\
\hline Support \#12 & 16039.27 & 71277.72 & 187.54 & 100.02 & 201.01 & 2.03 \\
\hline Support \#12A & 16032.12 & 71285.81 & 198.34 & 100.22 & 211.81 & 1.85 \\
\hline Support \#13 & 16025.55 & 71293.29 & 208.29 & 100.42 & 221.77 & 2.01 \\
\hline Support \#14 & 16019.07 & 71300.67 & 218.11 & 100.62 & 231.59 & 2.04 \\
\hline Support \#15 (Crest) & 16009.76 & 71310.97 & 232.00 & 100.93 & 245.48 & 0.00 \\
\hline End of Pipe at X-08 Ditch & 15997.10 & 71326.80 & 252.27 & 88.70 & 269.15 & -60.34 \\
\hline
\end{tabular}

\subsubsection{Continuous 2-Inch MFV Siphon Line Test Results Overview}

Continuous, 2-inch HDPE, siphon line, MFV tests were conducted from April 5 through April 7 , 1999. The 2-inch siphon line was initially primed using a venturi-type vacuum pump (Vaccon Model \# JS60M) driven by 85 -psig nitrogen gas. The vacuum pump would evacuate the air from the line and to fill the line with water from both the inlet at TGSC-1 and the outlet at the siphon discharge sump (see Figures 2 and 4). With an input of 80-psig nitrogen, this vacuum pump produces a vacuum flow of $0.3 \mathrm{scfm}$ at a vacuum of $9 \mathrm{in}-\mathrm{Hg}$ with an air consumption rate of 0.8 scfm. After the prime was established, the $1 / 2$-inch ball valve connecting the crest to the priming system was closed, the priming system was shut off, and the siphon was allowed to operate.

Figure 6 presents an overview of the water level elevations of well TNX-9D, TGSC-1, and the siphon discharge point (SDP) and the flow rate through the siphon line over the three days of 
testing. The average difference between the TNX-9D and TGSC-1 pre-operational water level elevations from April 4 and 5, 1999, was subtracted from the TNX-9D water level elevations to establish the estimated non-operating TGSC-1 water level elevations shown in Figure 6 . The difference between the water level elevations for the estimated non-operating TGSC-1 and the recorded SDP is equivalent to the total head available to drive the system. The total head available was utilized to drive the flow through TGSC-1 and the siphon line, which resulted in head losses in both during operation of the system. The difference between the water level elevations for the estimated non-operating TGSC-1 and the recorded TGSC-1 is equivalent to the head loss through TGSC-1. The difference between the water level elevations for the recorded TGSC -1 and the recorded SDP is equivalent to the head loss through the siphon line.

The average estimated non-operating TGSC-1 water level elevation during the period of testing was $92.74 \mathrm{ft}-\mathrm{msl}$. This water level was approximately one foot less than the average TGSC-1 water level elevation of $93.73 \mathrm{ft}$-msl utilized in the flow and velocity calculations of Table 1 . Additionally the average SDP water level elevation during the period of testing was $89.36 \mathrm{ft}-\mathrm{msl}$. This water level at the discharge was approximately $1 / 2$ a foot greater than the water elevation of $88.82 \mathrm{ft}-\mathrm{msl}$ utilized in the flow and velocity calculations of Table 1. Constructability issues required that the discharge point be placed upgradient of the location utilized in the Table 1 calculations. Due to this loss of approximately $1.5 \mathrm{ft}$ of head over the Table 1 assumed head, the siphon line velocities achieved during the test were substantially less than the average velocities calculated in Table 1.

Immediately after priming, the initial flow rate was approximately $5.4 \mathrm{gpm}$. The flow rate then declined significantly in a matter of 8 to 12 hours. The line was re-primed multiple times during the three days of testing. Each re-priming event resulted in maximum flow rates of between 6.0 and 7.9 gpm during re-priming, followed by a significant flow rate decline.

The total head available, the head losses associated with TGSC-1 and the siphon line, and the flow rate are presented for the entire three days of testing in Figure 7. The total available head during this period ranged from 3.3 to $3.6 \mathrm{ft}$. Upon initiation of flow after each re-priming event, the flow rate initially ranged from 5.4 to $6.2 \mathrm{gpm}$, the head loss associated with TGSC-1 initially ranged from 3.2 to $3.5 \mathrm{ft}$, and the loss associated with the siphon line initially ranged from 0.04 to $0.10 \mathrm{ft}$. The flow rates immediately after priming were consistent with those calculated based upon the available head. Over a short period of time, the head loss associated with the siphon line began to increase due to an accumulation of a gas-phase in the crest of the siphon line. The increase in siphon line head loss resulted in a decline in the flow rate. This resulted in less head loss due to flow through TGSC-1. This continued until the line was re-primed or the siphon line crest was completely blocked by an accumulated gas-phase, at which point flow ceased.

\subsubsection{Continuous 2-Inch MFV Siphon Line Test April 5 Results}

Two of the test runs (runs initiated after 4:00 p.m. on April 5 and 6) were allowed to operate until flow ceased naturally. The flow rate declines of these two test runs, along with the associated total available heads and head losses, are shown in detail in Figures 8 and 9. Figure 8 provides the data for the April 5, 1999, test run. A flow rate of approximately $5.3 \mathrm{gpm}$ was calculated for 
the conditions present at the time of this test run. The calculation can be found in Appendix A. The initial flow rate of $6 \mathrm{gpm}$ declined to zero in 8 hours and 50 minutes due to the accumulation of a gas-phase in the crest. The average flow rate was approximately $1.6 \mathrm{gpm}$. The total available head varied between approximately 3.38 and $3.40 \mathrm{ft}$. The siphon line head loss upon initiation of flow was initially approximately $0.1 \mathrm{ft}$ and increased to approximately that of the total available head $(\sim 3.4 \mathrm{ft})$, at which point the flow ceased. The increase in siphon line head loss over time parallels the accumulation of a gas-phase in the crest. The slope of the siphon line head loss decreased over time since a larger volume of gas was required with each increment of siphon line cross-sectional pluggage due to the curvature of the siphon line at the crest. The head loss due to flow through TGSC-1 decreased inversely with the increase in the siphon line head loss from approximately 3.27 to $0.04 \mathrm{ft}$. Since the TGSC-1 head loss is directly proportional to the flow rate, this resulted in the decrease in flow. The siphon line velocity of approximately 0.5 $\mathrm{ft} / \mathrm{s}$ was substantially less than both the calculated velocity of $0.91 \mathrm{ft} / \mathrm{s}$ and the calculated required MFV range of 0.73 to $1.37 \mathrm{ft} / \mathrm{s}$ from Table 1 . This substantially lower siphon line velocity occurred due to the loss of approximately 1.5 - $\mathrm{ft}$ of head over the Table 1 head as discussed in section 4.2.1.2. Therefore this decrease in flow over time for the continuous 2-inch siphon line was not unexpected.

\subsubsection{Continuous 2-Inch MFV Siphon Line Test April 6 Results}

Figure 9 provides the data for the April 6, 1999, test run. A flow rate of approximately $5.2 \mathrm{gpm}$ was calculated for the conditions present at the time of this test run. The calculation can be found in Appendix A. The initial flow rate of $6 \mathrm{gpm}$ declined to zero in 11 hours and 48 minutes due to the accumulation of a gas-phase in the crest. The average flow rate was approximately 1.6 gpm. The total available head varied between approximately 3.34 and $3.40 \mathrm{ft}$. The siphon line head loss upon initiation of flow was initially approximately $0.1 \mathrm{ft}$ and increased to approximately that of the total available head $(-3.4 \mathrm{ft})$, at which point the flow ceased. The increase in siphon line head loss over time parallels the accumulation of a gas-phase in the crest. The slope of the siphon line head loss decreased over time since a larger volume of gas is required with each increment of siphon line cross-sectional pluggage due to the curvature of the siphon line at the crest. The head loss due to flow through TGSC-1 decreased inversely with the increase in the siphon line head loss from approximately 3.24 to $0.03 \mathrm{ft}$. Since the TGSC-1 head loss is directly proportional to the flow rate, this resulted in the decrease in flow. The siphon line velocity of approximately $0.5 \mathrm{ft} / \mathrm{s}$ was substantially less than both the calculated velocity of 0.91 $\mathrm{ft} / \mathrm{s}$ and the calculated required MFV range of 0.73 to $1.37 \mathrm{ft} / \mathrm{s}$ from Table 1 . This substantially lower siphon line velocity occurred due to the loss of approximately $1.5-\mathrm{ft}$ of head over the Table 1 head as discussed in section 4.2.1.2. Therefore this decrease in flow over time for the continuous 2 -inch siphon line was not unexpected.

\subsubsection{Continuous 2-Inch MFV Siphon Line Test Temperature Results}

Figure 10 shows that the April 6,1999, test run lasted approximately 3 hours longer than the April 5, 1999, test run even though essentially identical total heads were available. This difference in run lengths can be attributed to a decreased de-gassing rate from the treated groundwater during the April 6, 1999, test run due to a difference in average temperature 
between the runs. The average temperature during the April 5, 1999, run was $23.9^{\circ} \mathrm{C}$. The average temperature during the April 6,1999 , run was $18.9^{\circ} \mathrm{C}$. The lower average temperature resulted in a greater dissolved-gas capacity of the treated water, and therefore less de-gassing.

\subsubsection{2-Inch Upward Leg to 1-1/4 -Inch Crest and Downward Leg MFV Siphon Line Results}

\subsubsection{2- to 1-1/4-Inch MFV Siphon Line Installation}

The 2-inch upward leg to 1-1/4-inch crest and downward leg MFV siphon line was installed from the TGSC-1 to the X-08 outfall ditch as shown in Figures 1 (plan), 3 (profile), 4 (crest and priming system), and 5 (discharge sump). This configuration utilized those portions of the previously installed continuous, 2-inch siphon line from TGSC-1 to the crest. The siphon line consisted of the following, in order, from TGSC-1 to the discharge point in the X-08 outfall ditch:

- Approximately 15-foot long, 2-inch diameter, stainless-steel riser out of TGSC-1 (see Figure 3)

- Approximately $230 \mathrm{ft}$ of 2 -inch diameter HDPE pipe (inside diameter $=2.067$ inches) at an average upward slope of $2.45 \%$ from TGSC-1 to immediately adjacent to the crest (see Figure 3)

- A tapping saddle clamped to the 2-inch HDPE pipe for installation of a vacuum gauge prior to the crest

- Approximately $31 \mathrm{ft}$ of 1-1/4-inch diameter HDPE pipe (inside diameter $=1.380$ inches) for the crest and downward slope (average $90 \%$ ) to the discharge point (see Figure 3)

- A tapping saddle clamped to the 1-1/4-inch diameter HDPE at the crest with a $1 / 2$ inch diameter, carbon-steel pipe and valve for connection to the priming system (see Figure 4)

- A priming system connected to the $1 / 2$-inch diameter, carbon-steel pipe at the crest, which utilized a nitrogen-driven, venturi-type, vacuum pump to pull the prime (see Figure 4)

The siphon line discharged into a 12-inch diameter PVC sump located in the X-08 outfall ditch to maintain a submerged siphon line outlet (see Figure 5). Table 5 provides the as-built coordinates, distances, elevations, lengths, and slopes of this configuration. To minimize discontinuities in the inside diameter of the siphon line, which could promote bubble accumulation, agglomeration, and entrapment, one continuous length of 2-inch HDPE pipe was installed from TGSC-1 to a location immediately adjacent to the crest. Additionally, one continuous length of $1-1 / 4$-inch HDPE pipe was utilized for the crest and to the SDP. Only five fittings were utilized within the siphon line, itself:

- A Dresser model 360 water repair clamp to connect the 2-inch diameter stainless steel riser (within TGSC-1) and the 2-inch diameter HDPE pipe (silicon caulk was utilized to ensure a positive seal between the pipes and clamp)

- A tapping saddle clamped to the 2-inch HDPE pipe for installation of a vacuum gauge prior to the crest 
- A 2-inch 90-degree elbow to orient the 2 - to $1-1 / 4$-inch reducer vertically

- A 2- to 1-1/4-inch reducer oriented vertically to preclude bubble accumulation

- A tapping saddle clamped to the 1-1/4-inch diameter HDPE at the crest of the 1-1/4-inch diameter HDPE pipe, with a $1 / 2$-inch diameter carbon-steel pipe and ball valve for connection to the priming system

Use of the 2-inch 90-degree elbow and the vertically oriented 2- to 1-1/4-inch reducer to transition between the 2- to $1-1 / 4$-inch lines, resulted in the $2-$ to $1-1 / 4$-inch line crest being $5 \mathrm{ft}$ above the location of the continuous 2 -inch line crest. This resulted in a higher operating vacuum in the 2 to 1-1/4-inch crest over that of the continuous 2-inch line crest. The use of eccentric reducers (not readily available) could minimize this increase in crest height.

To eliminate localized high points, the entire siphon line was placed on an engineered grade, with the crest as the only high point in the line from which the prime was pulled. A significant portion of the line was installed above grade, which was subject to thermal expansion. The HDPE line was installed so that the designated crest would remain the highest point in the line even with linear expansion of the HDPE due to temperature. Thermal expansion would be minimized with installation of the siphon line entirely underground.

Neither a hydrostatic nor a vacuum leak test was performed after reconfiguration of the siphon line. The 2-inch stainless steel riser and Dresser repair clamp would have had to be disconnected from the HDPE line to test the rest of the HDPE siphon line; therefore no leak test was performed. 
Table 5

TGSC-1 MFV 2-Inch Upward Leg to 1-1/4 -Inch Crest and Downward Leg Siphon Line As-Built Details

\begin{tabular}{|c|c|c|c|c|c|c|c|}
\hline \multirow[b]{2}{*}{ Location } & \multicolumn{2}{|c|}{ Coordinates } & \multirow{2}{*}{$\begin{array}{l}\text { Line } \\
\text { Size } \\
\text { (in) }\end{array}$} & \multirow{2}{*}{$\begin{array}{c}\text { Cumulative } \\
\text { Horizontal } \\
\text { Distance } \\
\text { from TGSC-1 } \\
\text { (ft) }\end{array}$} & \multirow{2}{*}{$\begin{array}{c}\text { Bottom of } \\
\text { Siphon } \\
\text { Elevation } \\
(\mathrm{ft}-\mathrm{msl})\end{array}$} & \multirow{2}{*}{$\begin{array}{c}\text { Cumulative } \\
\text { Siphon } \\
\text { Length } \\
\text { (ft) }\end{array}$} & \multirow{2}{*}{$\begin{array}{c}\text { Siphon } \\
\text { Slope } \\
(\%)\end{array}$} \\
\hline & $\begin{array}{l}\text { East } \\
\text { (ft) }\end{array}$ & $\begin{array}{c}\text { North } \\
\text { (ft) }\end{array}$ & & & & & \\
\hline Bottom Siphon Line & 16176.21 & 71150.24 & 2.00 & 0.00 & 82.00 & 0.00 & NA \\
\hline Top Siphon Line at TGSC-1 & 16176.21 & 71150.24 & 2.00 & 0.00 & 95.41 & 13.41 & up \\
\hline Edge $12 "$ casing at slot & 16175.80 & 71150.58 & 2.00 & 0.53 & 95.41 & 13.94 & elbow \\
\hline end box & 16171.57 & 71154.13 & 2.00 & 6.05 & 95.64 & 19.47 & 4.07 \\
\hline Ditch (within 3" pipe sleeve) & 16162.75 & 71161.61 & 2.00 & 17.62 & 95.96 & 31.04 & 2.81 \\
\hline Ditch (within 3" pipe sleeve) & 16153.82 & 71169.30 & 2.00 & 29.40 & 96.28 & 42.83 & 2.72 \\
\hline Ditch (within 3" pipe sleeve) & 16145.68 & 71176.16 & 2.00 & 40.05 & 96.55 & 53.48 & 2.54 \\
\hline Ditch (within 3" pipe sleeve) & 16137.92 & 71182.76 & 2.00 & 50.24 & 96.75 & 63.67 & 1.96 \\
\hline Ditch (within 3" pipe sleeve) & 16131.22 & 71188.37 & 2.00 & 58.98 & 96.94 & 72.41 & 2.17 \\
\hline Ditch (within 3" pipe sleeve) & 16119.01 & 71198.68 & 2.00 & 74.96 & 97.40 & 88.39 & 2.88 \\
\hline Support \#1 & 16101.14 & 71213.81 & 2.00 & 98.37 & 98.03 & 111.82 & 2.69 \\
\hline Support \#2 & 16090.94 & 71222.47 & 2.00 & 111.75 & 98.40 & 125.20 & 2.77 \\
\hline Support \#3 & 16081.12 & 71231.01 & 2.00 & 124.77 & 98.80 & 138.22 & 3.07 \\
\hline Support \#8 & 16078.63 & 71232.91 & 2.00 & 127.90 & 98.90 & 141.36 & 3.19 \\
\hline Support \#9 & 16068.33 & 71244.52 & 2.00 & 143.42 & 99.14 & 156.88 & 1.55 \\
\hline Support \#10 & 16055.14 & 71259.45 & 2.00 & 163.34 & 99.53 & 176.80 & 1.96 \\
\hline Support \#11 & 16045.32 & 71270.60 & 2.00 & 178.20 & 99.83 & 191.66 & 2.02 \\
\hline Support \#12 & 16039.27 & 71277.72 & 2.00 & 187.54 & 100.02 & 201.01 & 2.03 \\
\hline Support \#12A & 16032.12 & 71285.81 & 2.00 & 198.34 & 100.22 & 211.81 & 1.85 \\
\hline Support \#13 & 16025.55 & 71293.29 & 2.00 & 208.29 & 100.42 & 221.77 & 2.01 \\
\hline Support \#14 & 16019.07 & 71300.67 & 2.00 & 218.11 & 100.62 & 231.59 & 2.04 \\
\hline Support \#15 & 16009.76 & 71310.97 & 2.00 & 232.00 & 100.93 & 245.48 & 2.23 \\
\hline Crest & & & 1.25 & 233.75 & 105.96 & 250.80 & 0.00 \\
\hline End of Pipe at X-08 Ditch & 15997.10 & 71326.80 & 1.25 & 252.27 & 88.70 & 276.12 & -93.20 \\
\hline
\end{tabular}

\subsubsection{2- to 1-1/4-Inch MFV Siphon Line Test Results Overview}

The 2- to 1-1/4-inch HDPE siphon line, MFV tests were conducted from April 22 through April 29, 1999. The line was initially primed using a venturi-type vacuum pump (Vaccon Model \# JS60M) driven by 85-psig nitrogen gas to evacuate the air from the line and to fill the line with water from both the inlet at TGSC-1 and the outlet at the PVC sump (see Figures 3 and 4). With an input of 80-psig nitrogen, this vacuum pump produces a vacuum flow of $0.3 \mathrm{scfm}$ at a vacuum of 9 in- $\mathrm{Hg}$ with an air consumption rate of $0.8 \mathrm{scfm}$. After the prime was established, the $1 / 2$-inch ball valve connecting the crest to the priming system was closed, the priming system was shut off, and the siphon was allowed to operate. 
Figure 11 presents an overview of the water level elevations of well TNX-9D, TGSC-1, and the SDP and the flow rate through the siphon line over the six days of testing. The average difference between the TNX-9D and TGSC-1 pre-operational water level elevations from April 21, 22, 24, 25,26 , and 30,1999 , was subtracted from the TNX-9D water level elevations to establish the estimated non-operating TGSC-1 water level elevations shown in Figure 11. The difference between the water level elevations for the estimated non-operating TGSC-1 and the recorded SDP is equivalent to the total head available to drive the system. The total head available was utilized to drive the flow through TGSC-1 and the siphon line, which resulted in head losses in both during operation of the system. The difference between the water level elevations for the estimated non-operating TGSC-1 and the recorded TGSC-1 is equivalent to the head loss through TGSC-1. The difference between the water level elevations for the recorded TGSC- 1 and the recorded SDP is equivalent to the head loss through the siphon line.

The average estimated non-operating TGSC-1 water level elevation during the period of testing was $92.33 \mathrm{ft}$-msl. This water level was approximately $1.4 \mathrm{ft}$ less than the average TGSC-1 water level elevation of $93.73 \mathrm{ft}$-msl utilized in the flow and velocity calculations of Table 1 . Additionally the average SDP water level elevation during the period of testing was $89.20 \mathrm{ft}$-msl. This water level at the discharge was approximately $0.4 \mathrm{ft}$ greater than the water elevation of $88.82 \mathrm{ft}$-msl utilized in the flow and velocity calculations of Table 1. Constructability issues required that the discharge point be placed upgradient of the location utilized in the Table 1 calculations. Due to this loss of approximately $1.8 \mathrm{ft}$ of head over the Table 1 assumed head, the siphon line velocities achieved during the test were substantially less than the average velocities calculated in Table 1.

Immediately after priming, the initial flow rate was greater than $10 \mathrm{gpm}$. The flow rate then declined significantly within an hour. The line was re-primed multiple times during the six days of testing. Each re-priming event resulted in initial maximum flow rates during re-priming of between 4.6 and $11.9 \mathrm{gpm}$. This was followed by a more rapid flow rate decline than experienced during testing of the continuous 2 -inch siphon line. The more rapid flow rate decline was due to the smaller volume in the 1-1/4-inch crest for gas accumulation. The 1-1/4-inch siphon line crest has a smaller volume than the 2 -inch siphon line crest by a minimum factor of 2.24 based upon diameter alone. The smaller radius of pipe curvature associated with the $1-1 / 4-$ inch siphon line increases the factor of volume difference between the 1-1/4-inch and 2-inch siphon line crests to greater than 2.24 .

The total head available, the head losses associated with TGSC-1 and the siphon line, and the flow rate are presented for the entire six days of testing in Figure 12. The total available head during this period ranged from 2.944 to $3.290 \mathrm{ft}$. Upon initiation of flow immediately after each re-priming event, the flow rate initially ranged from 3.5 to $5.0 \mathrm{gpm}$, the head loss associated with TGSC-1 initially ranged from 2.120 to $2.877 \mathrm{ft}$, and the loss associated with the siphon line initially ranged from 0.180 to $0.979 \mathrm{ft}$. Over a short period of time, the head loss associated with the siphon line began to increase due to an accumulation of a gas-phase in the crest of the siphon line. The increase in siphon line head loss resulted in a decline in the flow rate. This in turn resulted in less head loss due to flow through TGSC-1. This continued until the line was reprimed or the siphon line crest was completely blocked by an accumulated gas-phase, at which 
point flow ceased.

\subsubsection{2- to 1-1/4-Inch MFV Siphon Line Test April 23 Results}

The test runs with the longest and shortest duration after priming are shown in detail in Figures 13 and 14. The flow rate declines of these two test runs, along with the associated total available heads and head losses, are shown. These test runs were allowed to operate until the accumulated gas-phase completely blocked the siphon line crest and flow ceased. Figure 13 provides the data from the April 23, 1999, test run, which was the shortest duration run after priming. A flow rate of approximately $4.6 \mathrm{gpm}$ was calculated for the conditions present at the time of this test run. The calculation can be found in Appendix A. The initial recorded flow rate of $3.9 \mathrm{gpm}$ declined to zero in 80 minutes due to the accumulation of a gas-phase in the crest. The average flow rate was approximately $1.5 \mathrm{gpm}$. The total available head varied between 3.05 and $3.08 \mathrm{ft}$. Upon initiation of flow the siphon line head loss was $0.5 \mathrm{ft}$ and increased to approach that of the total available head $(\sim 3.0 \mathrm{ft})$, at which point the flow ceased. The increase in siphon line head loss over time parallels the accumulation of a gas-phase in the crest. The slope of the siphon line head loss decreased over time since a larger volume of gas is required with each increment of siphon line cross-sectional pluggage due to the curvature of the siphon line at the crest. The head loss due to flow through TGSC-1 decreased inversely with the increase in the siphon line head loss from approximately 2.55 to $0.22 \mathrm{ft}$. Since the TGSC-1 head loss is directly proportional to the flow rate, this resulted in the decrease in flow.

The velocity of $0.98 \mathrm{ft} / \mathrm{s}$ at the calculated flow rate was significantly less than the Table 1 calculated velocity of $2.13 \mathrm{ft} / \mathrm{s}$ primarily due to the 1.8 foot decrease in head over the average assumed head used in the Table 1 calculations. The $0.98 \mathrm{ft} / \mathrm{s}$ velocity is less than the Equation 2 calculated required MFV of $1.12 \mathrm{ft} / \mathrm{s}$, but it is significantly greater than the Equation 1 calculated required MFV of $0.60 \mathrm{ft} / \mathrm{s}$ :

$$
\begin{aligned}
& -\mathrm{V}=0.58\left(\operatorname{SQRT}\left(32.2 \mathrm{ft} / \mathrm{s}^{2} \times 0.1150 \mathrm{ft}\right)\right)=1.12 \mathrm{ft} / \mathrm{s} \\
& -\mathrm{V}=0.31\left(\operatorname{SQRT}\left(32.2 \mathrm{ft} / \mathrm{s}^{2} \times 0.1150 \mathrm{ft}\right)\right)=0.60 \mathrm{ft} / \mathrm{s}
\end{aligned}
$$

The Table 1 calculated required MFV is not applicable since calculations assumed tubing with inside diameters equal to the nominal size was used. The velocity within the siphon line was within the range of acceptable velocities for operation in the MFV mode. However, in this case, the siphon line could not maintain continuous, consistent, full siphon flow utilizing MFV. Therefore a higher velocity than achieved was required to operate in the MFV mode. The increased dissolved hydrogen in the water transported within the siphon line additionally compounded the need for a higher velocity. As discussed in Section 5.2, the zero-valent iron treatment of groundwater caused the dissolved hydrogen concentration to increase approximately six orders of magnitude above background groundwater concentrations (see Table 15). This increase in dissolved hydrogen produced an increased de-gassing volume of a hydrogen-rich gas within the siphon line over what would occur with the transport of untreated groundwater. This resulted in the requirement for an MFV greater than would be required for the transport of untreated groundwater. 


\subsubsection{4 -2 to 1-1/4-Inch MFV Siphon Line Test April 29 Results}

Figure 14 provides the data for the April 29, 1999, test run, which was the longest duration run after priming. A flow rate of approximately $4.5 \mathrm{gpm}$ was calculated for the conditions present at the time of this test run. The calculation can be found in Appendix A. The initial flow rate of 5 gpm declined to zero in 6 hours and 11 minutes due to the accumulation of a gas-phase in the crest. The average flow rate was $1.6 \mathrm{gpm}$. The total available head varied between approximately 2.95 and $3.01 \mathrm{ft}$. Upon initiation of flow, the siphon line head loss was initially $0.2 \mathrm{ft}$ and increased to approximately that of the total available head $(\sim 3.0 \mathrm{ft})$, at which point the flow ceased. The increase in siphon line head loss over time parallels the accumulation of a gasphase in the crest. The slope of the siphon line head loss decreased over time since a larger volume of gas is required with each increment of siphon line cross-sectional pluggage due to the curvature of the siphon line at the crest. The head loss due to flow through TGSC-1 decreased inversely with the increase in the siphon line head loss from approximately 2.77 to $0.03 \mathrm{ft}$. Since the TGSC-1 head loss is directly proportional to the flow rate, this resulted in the decrease in flow.

The velocity of $0.96 \mathrm{ft} / \mathrm{s}$ at the calculated flow rate was significantly less than the Table 1 calculated velocity of $2.13 \mathrm{ft} / \mathrm{s}$ primarily due to the 1.8 foot decrease in head over the average assumed head used in the Table 1 calculations. The $0.96 \mathrm{ft} / \mathrm{s}$ velocity is less than the Equation 2 calculated required MFV of $1.12 \mathrm{ft} / \mathrm{s}$, but it is significantly greater than the Equation 1 calculated required MFV of $0.60 \mathrm{ft} / \mathrm{s}$ (see previous calculations above). The velocity within the siphon line was within the range of acceptable velocities for operation in the MFV mode. However, in this case, the siphon line was not able to maintain continuous, consistent, full siphon flow utilizing MFV. Therefore a higher velocity than achieved was required to operate in the MFV mode. The increased dissolved hydrogen in the water transported within the siphon line additionally compounded the need for a higher velocity. As discussed in Section 5.2, the zero-valent iron treatment of groundwater caused the dissolved hydrogen concentration to increase approximately six orders of magnitude above background groundwater concentrations (see Table 15). This increase in dissolved hydrogen produced an increased de-gassing volume of a hydrogen-rich gas within the siphon line over that which would occur with the transport of untreated groundwater. This resulted in the requirement for an MFV greater than would be required for the transport of untreated groundwater.

\subsubsection{2- to 1-1/4-Inch MFV Siphon Line Test Temperature Results}

As indicated above, the duration of the April 29, 1999, run was 4 hours and 51 minutes longer than that of the April 23,1999, run even though the total available heads were essentially identical. This difference in run lengths again can be attributed to a decreased de-gassing rate from the treated groundwater during the April 29, 1999, test run, which is due to a difference in average temperature between the runs. The average temperature during the April 23, 1999, run was $30.5^{\circ} \mathrm{C}$. The average temperature during the April 29,1999 , run was $11.7^{\circ} \mathrm{C}$. The lower average temperature resulted in a greater dissolved-gas capacity of the treated water, and therefore less de-gassing. 
Figure 15 provides a comparison of the flow rates and run duration for all of the $2-$ to $1-1 / 4$-inch HDPE siphon line, MFV test runs. The test runs that were conducted during periods of lower average temperatures resulted in longer test runs. The April 22 and 23, 1999, test runs, while demonstrating this behavior when compared among themselves, have shorter run durations than would be anticipated when compared to the April 26 through April 29, 1999, runs. This may be due to the fact that TGSC-1 was idle for fifteen days prior to the April 22 and 23, 1999, runs. During this time reaction gasses could have accumulated within the water in the cell, which were not present during the April 26 through 29, 1999, runs. The estimated gas accumulation volume of the 1-1/4-inch crest that results in shutting down siphon flow is approximately 0.16 gallons. Table 6 provides the minimum estimated gas accumulation rates versus temperature for the April 26 through 29, 1999, runs based upon this volume. The minimum estimated gas accumulation rates range from 0.026 gallons/hour at an atmospheric temperature of $11.7^{\circ} \mathrm{C}$ to 0.063 gallons/hour at an atmospheric temperature of $30.5^{\circ} \mathrm{C}$. Again, lower average temperatures resulted in a greater dissolved-gas capacity of the treated water, and therefore less de-gassing. A gas accumulation rate of approximately 0.3 gallons/hour was estimated from the previous Phase II single-cell testing data [Phifer, et. al., 1999]. The deviation between the Phase II single-cell and the Phase II MFV gas accumulation rates may be due to the following:

- The Phase II single-cell air chamber may have collected essentially all of the gas, which de-gassed.

- The Phase II MFV siphon line may have been able to sweep a large percentage, but not all, of the gas that de-gassed out the end of the siphon line.

Table 6

Gas Accumulation Rates Versus Temperature

\begin{tabular}{|c|c|c|}
\hline $\begin{array}{c}\text { Atmospheric } \\
\text { Temperature } \\
\left({ }^{\circ} \mathrm{C}\right)\end{array}$ & $\begin{array}{c}\text { Duration of Run } \\
(\mathrm{min} / \mathrm{hrs})\end{array}$ & $\begin{array}{c}\text { Minimum Estimated Gas } \\
\text { Accumulation Rate } \\
(\mathrm{gph})\end{array}$ \\
\hline 11.7 & $371 / 6.18$ & 0.026 \\
\hline 13.9 & $336 / 5.60$ & 0.029 \\
\hline $18.5^{1}$ & $171 / 2.85$ & 0.056 \\
\hline 26.1 & $168 / 2.80$ & 0.057 \\
\hline 30.5 & $152 / 2.53$ & 0.063 \\
\hline
\end{tabular}

Notes to Table 6:

${ }^{1}$ The gas accumulation rate for this temperature is slightly over estimated since it is not based upon the flow rate going to zero (see Figure 15)

${ }^{2}$ Gas Accumulation Rate (gph) $=0.16$ gallons $\div$ Duration of Run (hrs) 


\subsection{COMBINATION MFV AND CONTINUOUS NITROGEN-PURGE TEST RESULTS}

\subsubsection{Combination MFV / CNP Test Overview}

Because MFV could not maintain continuous, consistent, full siphon flow in the TGSC-1, 2- to 1-1/4-inch HDPE siphon line, a combination MFV and continuous nitrogen-purge (CNP) test was conducted. CNP entails the continuous use of a nitrogen-driven vacuum pump to remove gas bubbles from the crest of the siphon line. During the CNP portion of the test, gas from the crest of the siphon line was continuously removed by the existing priming system shown in Figure 4 although with a different vacuum pump. The Vaccon Model \# JS60M vacuum pump was replaced by a Vaccon Model \# 52-1005-TT venturi-type, mini-vacuum pump. This vacuum pump is driven by 20-psig nitrogen gas and has a lower air consumption rate than the Model \# JS60M. CNP functions in a manner similar to an air chamber. However, rather than storing the gasses in a chamber above the siphon line, the gasses are continuously purged from the siphon line. The combination test run was accomplished in the following three successive stages: an initial MFV stage, a secondary CNP stage, and a final MFV stage.

\subsubsection{Initial MFV Stage Results}

Figure 16 provides the flow rates associated with the April 27, 1999 combination MFV and CNP test run. A flow rate of approximately $4.7 \mathrm{gpm}$ was calculated for the conditions present at the time of this test run. The calculation can be found in Appendix A. During the initial MFV stage, the initial flow rate of $4.9 \mathrm{gpm}$ declined to $3.5 \mathrm{gpm}$ in a matter of 48 minutes due to the accumulation of a gas-phase in the crest.

\subsubsection{Secondary CNP Stage Results}

After the initial MFV stage was completed, the secondary CNP stage of the test began. The Vaccon Model \# 52-1005-TT venturi-type, mini-vacuum pump operated using $17 \mathrm{psig}$ of nitrogen, which produced a vacuum of $12 \mathrm{in}-\mathrm{Hg}$ at the crest. The flow rate during the CNP stage ranged from 3.9 to $5.2 \mathrm{gpm}$, with an average of $4.4 \mathrm{gpm}$ (see Figure 16). The relatively large flow rate variation is attributable to the priming system, which was designed to optimize priming, not to optimize continuous gas removal. Bubbles accumulated in the siphon line crest until the agglomerated bubble was large enough to be pulled out of the siphon line by the modified priming system. Immediately after the agglomerated bubble was pulled from the siphon line, the flow rate increased. This bubble accumulation and agglomeration followed by removal occurred cyclically, resulting in cyclic flow rates.

Figure 17 provides the combination test run flow rate, along with the total available head and head losses associated with this run. During the secondary CNP stage, the total available head varied between 3.09 and $3.11 \mathrm{ft}$. The siphon line head loss varied between 0.23 and $0.74 \mathrm{ft}$. This variation was due to alternate temporary bubble accumulation in the siphon line crest followed by bubble removal as outlined above. The TGSC-1 head loss varied inversely with the siphon line head loss and ranged between approximately 2.36 and $2.69 \mathrm{ft}$. The variable siphon head loss, which in turn resulted in an inversely variable TGSC-1 head loss, finally resulted in the 
variable flow rate. The flow rate varied directly with the TGSC-1 head loss and inversely with the siphon line head loss.

CNP established continuous, consistent, full siphon flow with this setup.

\subsubsection{Final MFV Stage Results}

The final MFV stage began at an initial flow rate of $4.4 \mathrm{gpm}$ and declined to zero in 2 hours and 32 minutes due to the accumulation of a gas-phase in the crest. The average flow rate for this stage was $2.1 \mathrm{gpm}$ (see Figure 16). A flow rate of approximately $4.7 \mathrm{gpm}$ was calculated for the conditions present at the time of this test run. The calculation can be found in Appendix A. During the final MFV stage, the total available head varied between 3.09 and $3.12 \mathrm{ft}$ (see Figure 17). Upon initiation of flow the siphon line head loss was $0.2 \mathrm{ft}$. This head loss increased to close to the total available head $(\sim 3.0 \mathrm{ft})$, at which point the flow ceased. The increase in siphon line head loss over time parallels the gas-phase accumulation in the crest. The slope of the siphon line head loss decreased over time since a larger volume of gas is required with each increment of siphon line cross-sectional pluggage due to the curvature of the siphon line at the crest. The head loss due to flow through TGSC-1 decreased inversely with the increase in the siphon line head loss from 2.88 to $0.15 \mathrm{ft}$. The TGSC-1 head loss is directly proportional to the flow rate, which resulted in the decrease in flow.

The velocity of $1.00 \mathrm{ft} / \mathrm{s}$ at the calculated flow rate was significantly less than the Table 1 calculated velocity of $2.13 \mathrm{ft} / \mathrm{s}$ primarily due to the $1.8 \mathrm{foot}$ decrease in head over the average assumed head used in the Table 1 calculations. The $0.96 \mathrm{ft} / \mathrm{s}$ velocity is less than the Equation 2 calculated required MFV of $1.12 \mathrm{ft} / \mathrm{s}$, but it is significantly greater than the Equation 1 calculated required MFV of $0.60 \mathrm{ft} / \mathrm{s}$ (see previous calculations in section 4.2.2). The velocity within the siphon line was within the range of acceptable velocities for operation in the MFV mode. However, in this case, the siphon line was not able to maintain continuous, consistent, full siphon flow utilizing MFV. Therefore a higher velocity than achieved was required to operate in the MFV mode. The increased dissolved hydrogen in the water transported within the siphon line additionally compounded the need for a higher velocity. As discussed in Section 5.2, the zerovalent iron treatment of groundwater caused the dissolved hydrogen concentration to increase approximately six orders of magnitude above background groundwater concentrations (see Table 15). This increase in dissolved hydrogen produced an increased de-gassing volume of a hydrogen-rich gas within the siphon line over what would occur with the transport of untreated groundwater. This resulted in the requirement for a minimum flushing velocity greater than would be required for the transport of untreated groundwater.

Again MFV was not able to maintain continuous, consistent, full siphon flow, but by using CNP full siphon flow was established.

\subsubsection{Sampling Atmospheric Leakage Significance}

As detailed in sections 5.2.3.2 and 5.2.3.3, atmospheric air leaked into the siphon line or into the associated priming line. This leak occurred during the sampling event itself, and it may have 
occurred throughout testing of the 2- to 1-1/4-inch siphon line configuration. However, data associated with the gas accumulation rates and run durations versus crest gas storage volumes of both siphon configurations indicate that any such leakage was insignificant relative to degassing. The crest gas accumulation rates increased as the temperature increased (see Table 6). This would be expected from accumulation due to de-gassing. Atmospheric leak rates into the siphon, on the other hand, are not controlled by temperature but by the vacuum level, which remained relatively constant. Since the gas generation rate varied significantly with temperature, it is not likely that atmospheric leakage played a significant role in shutting the siphon line down.

This lack of significance is also supported by a comparison of the different crest gas storage volumes (volume factor difference) and the different durations of test runs at similar temperatures (duration factor difference) between the 2-inch and 1-1/4-inch siphon line crests. The 2-inch siphon line was shown not to leak through hydrostatic leak testing, whereas no leak testing was conducted on the 2 to $1-1 / 4-$ inch siphon line. Possible atmospheric leakage to the $1-1 / 4-$ inch siphon line would be insignificant if the volume factor difference and the duration factor difference between the two siphon line configurations were essentially equivalent. An estimate of the volume factor difference can be made based upon the inside cross-sectional areas of the 2 and 1-1/4-inch lines. The volume factor difference, based only upon the inside cross-sectional areas of the lines and not on the actual volumes, will underestimate the actual difference. In order to obtain the actual crest gas storage volumes, the crest radius of curvature for both lines would need to be known, however it was not determined for the 2-inch line. However it is known that the crest radius of curvature was greater for the 2 -inch crest than for the 1-1/4-inch crest due to the greater stiffness of the 2-inch line. Therefore the volume factor difference obtained based upon the inside cross-sectional areas is an underestimate. Table 7 presents the volume factor difference and duration factor difference. The volume factor difference, which is an underestimate, is 2.24 whereas the duration factor difference, which should be exact, is 3.15. Therefore based upon the known underestimate of the volume factor difference, the factors are considered equivalent, which supports the conclusion that the leakage did not play a significant role in shutting down the siphon line. In summary, atmospheric leakage detected during sampling the 1-1/4-inch siphon line crest is considered insignificant relative to the de-gassing in shutting down the siphon line for the following reasons:

- The gas accumulation rates are controlled by de-gassing rather than by atmospheric leakage.

- The variation in run duration between the 2 -inch continuous and 2 to $1-1 / 4-$ inch siphon lines are due to the difference in the gas storage volumes of their crests.

Even though in this case atmospheric leakage was insignificant in shutting down the 2 to $1-1 / 4-$ inch siphon line, it demonstrates that a siphon line can be primed and operation initiated with minor leaks. However, atmospheric leakage will decrease the ability to operate in the MFV mode and increase air chamber recharging frequency. Therefore vacuum leak testing must be conducted prior to operation to ensure that leaks are not present. 
Table 7

Volume Factor Difference Versus Duration Factor Difference

\begin{tabular}{|c|c|c|c|c|c|c||}
\hline $\begin{array}{c}\text { Pipe } \\
\text { Nominal } \\
\text { Diameter } \\
\text { (inch) }\end{array}$ & $\begin{array}{c}\text { Pipe } \\
\text { Inside } \\
\text { Diameter } \\
\text { (inch) }\end{array}$ & $\begin{array}{c}\text { Pipe } \\
\text { Cross- } \\
\text { sectional } \\
\text { Area } \\
\text { (sq. in) }\end{array}$ & $\begin{array}{c}\text { Minimum } \\
\text { Volume } \\
\text { Factor } \\
\text { Difference }\end{array}$ & $\begin{array}{c}\text { Temperature } \\
\left({ }^{\circ} \text { C) }\right.\end{array}$ & $\begin{array}{c}\text { Run } \\
\text { Duration } \\
\text { (minutes) }\end{array}$ & $\begin{array}{c}\text { Duration } \\
\text { Factor } \\
\text { Difference }\end{array}$ \\
\hline 2 & 2.067 & 3.36 & 2.24 & 23.9 & 530 & 3.15 \\
\hline $1-1 / 4$ & 1.380 & 1.50 & & 26.1 & 168 & \\
\hline
\end{tabular}

${ }^{1}$ Pipe Cross-sectional Area $=1 / 4 \Pi$ (diameter $)^{2}$

${ }^{2}$ Minimum Volume Factor Difference $=2$-inch Pipe Cross-sectional Area $\div 1-1 / 4$ Pipe Crosssectional Area; The smaller radius of pipe curvature associated with the 1-1/4-inch siphon line increases the factor of volume difference between the 1-1/4-inch and 2-inch siphon line crests to greater than 2.24.

${ }^{3}$ Duration Factor Difference $=2$-inch Run Duration $\div$ 1-1/4-inch Run Duration

\subsection{MFV / CNP TEST RESULT SUMMARY}

MFV testing of both the continuous 2-inch and the 2-inch upward leg to 1-1/4-inch crest and downward leg siphon line configurations were conducted. The continuous 2-inch HDPE siphon line MFV tests were conducted from April 5 through April 7, 1999. The 2-inch upward leg to 1$1 / 4$-inch crest and downward leg HDPE siphon line MFV tests were conducted from April 22 through April 29, 1999.

To ensure no leaks existed in the continuous 2-inch siphon line, a hydrostatic leak test at 15 psig was conducted. No leaks were detected during the hydrostatic leak test. A vacuum leak test was not performed. After the continuous 2 -inch siphon line was primed initial flow rates were consistent with the calculated flow rates based upon the available head difference. However, a gas-phase began accumulating in the crest a short time after priming, which resulted in decreased flow over time to zero. The decrease in siphon flow over time for the continuous 2-inch siphon line was not unexpected since the total available head at the time of the test was significantly less than average. This resulted in a line velocity substantially less than the range of calculated required MFV.

Neither a hydrostatic nor a vacuum leak test was performed for the 2- to $1-1 / 4$-inch siphon line prior to operation. Upon initiation of priming, leaks were detected audibly. The leaks that could be detected audibly were found and repaired. After leak repair and priming of the 2 to $1-1 / 4$-inch siphon line, initial flow rates were consistent with the calculated flow rates based upon the available head difference. However, a gas-phase began accumulating in the crest a short time after priming, which resulted in decreased flow over time to zero. The gas accumulation rates range from 0.026 gallons/hour at an atmospheric temperature of $11.7^{\circ} \mathrm{C}$ to 0.063 gallons/hour at an atmospheric temperature of $30.5^{\circ} \mathrm{C}$. The flow rate decline of the 2- to $1-1 / 4-$ inch siphon line was more rapid than that of the continuous 2-inch siphon line due to the smaller 1-1/4-inch crest 
volume for gas accumulation. Although a leak of atmospheric air into the siphon line or into the associated priming line occurred during sampling of the siphon line crest gas-phase, it is not likely that atmospheric leakage played a significant role in shutting down the siphon line for the following reasons:

- The gas accumulation is controlled by de-gassing rather than by atmospheric leakage.

- The variation in run duration between the 2-inch continuous and 2 to 1-1/4-inch siphon lines are due to the difference in the gas storage volumes of their crests.

Therefore, the 2- to 1-1/4-inch MFV siphon line test adequately represents the ability of the MFV mode of operation to maintain continuous, consistent, full siphon flow under the conditions present at the time of the test. The velocity within the siphon line was within the range of acceptable velocities for operation in the MFV mode (Equations 1 and 2). However, in this case, the MFV mode of operation was not able to maintain continuous, consistent, full siphon flow. Therefore a higher velocity than achieved was required to operate in the MFV mode. Additionally, the increased dissolved 'hydrogen in the water transported within the siphon line compounded the requirement for a higher velocity. This resulted in the requirement for an MFV greater than would be required for the transport of untreated groundwater.

The following are two other items of note associated with these MFV tests:

- Lower average temperatures result in a greater dissolved-gas capacity for the treated water, which results in less de-gassing within the siphon line.

- A siphon line can be primed and operation initiated with minor atmospheric leaks. Additionally, if the gas is removed from the line (i.e., an air chamber or CNP is used to remove gas), the siphon line can be operated with minor atmospheric leaks. Therefore, siphon priming, operation initiation, and operation alone do not assure that atmospheric leaks are not present. Atmospheric leakage will decrease the ability to operate utilizing MFV and will increase the air chamber recharging frequency. This makes it necessary to perform vacuum leak testing prior to operation to ensure that leaks are not present.

Because MFV did not maintain continuous, consistent, full siphon flow in this case, a CNP test was conducted on April 27, 1999. During the CNP test, gas was removed from the crest of the 2to $1-1 / 4-$ inch siphon line continuously using the existing priming system. A CNP is analogous to using an air chamber although instead of storing the gasses in a chamber above the siphon line, the gasses are continuously purged from the siphon line using a nitrogen-driven vacuum pump. A flow rate of approximately $4.7 \mathrm{gpm}$ was calculated for the conditions present at the time of this test run. The actual flow rate achieved during the CNP test ranged from 3.9 to $5.2 \mathrm{gpm}$, with an average of $4.4 \mathrm{gpm}$. By using CNP, full siphon flow was maintained in a continuous and consistent manner. 


\subsection{PHASE II MFV SAMPLING AND ANALYSIS}

\subsection{SAMPLING AND ANALYSIS}

One round of sampling and analysis for field parameters, CVOCs, and dissolved gasses was conducted for each of the two test runs. Additionally, sampling and analysis of the siphon crest gas and NPDES sampling and analysis for CVOCs and toxicity were conducted during the second test run. Table 8 provides a summary of the chemical parameter groups that were monitored, the associated monitoring location, and the associated sampling method. Table 9 provides the parameters monitored within each chemical parameter group and the associated analytical method and sample volume and bottle information.

Table 8

Monitoring Location, Chemical Parameter Groups, and Sampling Method

\begin{tabular}{|c|c|c|}
\hline $\begin{array}{l}\text { Monitoring } \\
\text { Location }\end{array}$ & $\begin{array}{c}\text { Chemical } \\
\text { Parameter } \\
\text { Group }\end{array}$ & $\begin{array}{l}\text { Sampling } \\
\text { Method }\end{array}$ \\
\hline \multirow{3}{*}{$\begin{array}{c}\text { Well } \\
\text { TCM-2 }\end{array}$} & Field & Purge with Redi-Flo2 and flow through YSI \\
\hline & CVOCs & Purge and pull sample with syringe from nylon sampling tube \\
\hline & Dissolved gasses & $\begin{array}{l}\text { Per Microseeps SOP AM-19 with a peristaltic pump } \\
\text { (EMS-approved Bubble Strip Method) }\end{array}$ \\
\hline \multirow{3}{*}{$\begin{array}{c}\text { Well } \\
\text { TCM-4 }\end{array}$} & Field & Purge with Redi-Flo2 and flow through YSI \\
\hline & CVOCs & Purge and pull sample with syringe from nylon sampling tube \\
\hline & Dissolved gasses & $\begin{array}{l}\text { Per Microseeps SOP AM-19 with a peristaltic pump } \\
\text { (EMS-approved Bubble Strip Method) }\end{array}$ \\
\hline \multirow{3}{*}{$\begin{array}{l}\text { GeoSiphon } \\
\text { Cell } \\
\text { (TGSC-1) }\end{array}$} & Field & Lower YSI into 12-inch SS casing \\
\hline & CVOCs & Pull sample with syringe from nylon sampling tube \\
\hline & Dissolved gasses & $\begin{array}{l}\text { Per Microseeps SOP AM-19 with a peristaltic pump } \\
\text { (EMS-approved Bubble Strip Method) }\end{array}$ \\
\hline Siphon Crest & Gasses & $\begin{array}{l}\text { Per Microseeps SOP AM-19 with a gas-tight syringe } \\
\text { (EMS-approved procedure) }\end{array}$ \\
\hline \multirow{3}{*}{$\begin{array}{c}\text { Siphon } \\
\text { Discharge } \\
\text { Point (SDP) }\end{array}$} & Field & Lower YSI into 12-inch PVC discharge sump \\
\hline & CVOCs & Pull sample with syringe from nylon sampling tube \\
\hline & Dissolved gasses & $\begin{array}{l}\text { Per Microseeps SOP AM-19 with a peristaltic pump } \\
\text { (EMS-approved Bubble Strip Method) }\end{array}$ \\
\hline \multirow[t]{2}{*}{$\begin{array}{c}\text { (NPDES } \\
\mathrm{X}-19)\end{array}$} & $\begin{array}{l}\text { NPDES } \\
\text { CVOCs }\end{array}$ & Bailer grab sample from 12-inch PVC discharge sump \\
\hline & $\begin{array}{l}\text { NPDES } \\
\text { A-TOX }\end{array}$ & $\begin{array}{l}\text { 24-hour flow proportional samples taken with an ISCO sampler from } \\
\qquad 12 \text { inch PVC discharge sump }\end{array}$ \\
\hline
\end{tabular}


Notes to Table 8: A-TOX = Ceriodaphnia Dubia, 48-hour, Static, Acute Toxicity Test at an Instream Waste Concentration (IWC) of 33\%; YSI = Yellow Springs, Inc. Multi-Parameter Water Quality Monitor; SOP = Standard Operating Procedure

Table 9

Chemical Parameters, Analytical Method, and Sample Volume/Bottle

\begin{tabular}{|c|c|c|c|c|c|}
\hline Lab & $\begin{array}{l}\text { Sample } \\
\text { Medium }\end{array}$ & Parameters & $\begin{array}{l}\text { Analytical } \\
\text { Method }\end{array}$ & $\begin{array}{l}\text { Sample } \\
\text { Volume }\end{array}$ & $\begin{array}{c}\text { Sample } \\
\text { Bottle }\end{array}$ \\
\hline \multicolumn{6}{|c|}{ Field Parameters } \\
\hline EST & Water & $\begin{array}{c}\mathrm{pH}, \text { temperature, specific } \\
\text { conductance, dissolved oxygen, } \\
\text { redox potential }\end{array}$ & YSI & NA & NA \\
\hline \multicolumn{6}{|c|}{ Chlorinated Volatile Organic Compounds (CVOCs) } \\
\hline EST & Water & $\begin{array}{c}\text { tetrachloroethylene, } \\
\text { trichloroethylene, } \\
\text { 1,1-dichloroethylene, } \\
\text { cis-1,2-dichloroethylene, } \\
\text { trans-1,2-dichloroethylene, carbon } \\
\text { tetrachloride, chloroform, and } \\
\text { 1,1,1-trichloroethane }\end{array}$ & $\begin{array}{c}\text { GC- } \\
\text { ECD/FID } \\
\text { screening } \\
\text { method }\end{array}$ & $7.5 \mathrm{ml}$ & $\begin{array}{l}20 \mathrm{ml} \\
\text { headspace } \\
\text { vials }\end{array}$ \\
\hline $\begin{array}{l}\text { Micro- } \\
\text { seeps, } \\
\text { Inc. }\end{array}$ & Water & $\begin{array}{c}\text { tetrachloroethylene, } \\
\text { trichloroethylene, } \\
\text { cis-1,2-dichloroethylene, } \\
\text { vinyl chloride, carbon tetrachloride, } \\
\text { chloroform, and } 1,1,1- \\
\text { trichloroethane }\end{array}$ & $\begin{array}{c}\text { SW } 846 \\
\text { Method } \\
8021\end{array}$ & $\begin{array}{c}\text { As } \\
\text { required } \\
\text { by } \\
\text { Micro- } \\
\text { seeps }\end{array}$ & $\begin{array}{l}\text { As } \\
\text { provided by } \\
\text { Microseeps }\end{array}$ \\
\hline $\begin{array}{l}\text { SES, } \\
\text { Inc. }\end{array}$ & Water & $\begin{array}{c}\text { tetrachloroethylene, } \\
\text { trichloroethylene, } \\
\text { cis-1,2-dichloroethylene, } \\
\text { vinyl chloride }\end{array}$ & $\begin{array}{l}\text { SW } 846 \\
\text { Method } \\
8260\end{array}$ & $80 \mathrm{ml}$ & $\begin{array}{c}40 \mathrm{ml} \mathrm{VOA} \\
\text { bottles }\end{array}$ \\
\hline \multicolumn{6}{|c|}{ Gasses and Dissolved gasses } \\
\hline $\begin{array}{l}\text { Micro- } \\
\text { seeps, } \\
\text { Inc. }\end{array}$ & $\begin{array}{l}\text { Gas or } \\
\text { Water } \\
\text { (dissolved } \\
\text { gasses) }\end{array}$ & $\begin{array}{l}\text { nitrogen, oxygen, carbon dioxide, } \\
\text { carbon monoxide, methane, } \\
\text { hydrogen, ethane, ethylene }\end{array}$ & $\begin{array}{l}\text { Microseeps } \\
\text { SOP } \\
\text { AM-19 } \\
\text { (EMS- } \\
\text { approved } \\
\text { procedure) }\end{array}$ & $\begin{array}{c}\text { As } \\
\text { required } \\
\text { by } \\
\text { Micro- } \\
\text { seeps }\end{array}$ & $\begin{array}{l}\text { As } \\
\text { provided by } \\
\text { Microseeps }\end{array}$ \\
\hline \multicolumn{6}{|c|}{ Toxicity } \\
\hline $\begin{array}{l}\text { SES, } \\
\text { Inc. }\end{array}$ & Water & $\begin{array}{c}\text { Ceriodaphnia Dubia, } 48 \text {-hour, } \\
\text { Static, Acute Toxicity Test at an In- } \\
\text { stream Waste Concentration (IWC) } \\
\text { of } 33 \%\end{array}$ & $\begin{array}{c}\text { EPA-600/4- } \\
90-027 \\
\text { (Weber) }\end{array}$ & $4 \mathrm{~L}$ & $\begin{array}{l}2 \text { L HDPE } \\
\text { bottles }\end{array}$ \\
\hline
\end{tabular}


Notes to Table 9: EST = Environmental Sciences and Technology Department (the CVOC analysis conducted by EST is a screening level of analysis); SES, Inc. = Shealy Environmental Services, Inc. sampling and analysis conducted under the NPDES program; YSI = Yellow Springs, Inc. Multi-Parameter Water Quality Monitor; GC-ECD/FID $=$ gas chromatograph equipped with an electron capture detector and a flame ionization detector; SOP $=$ Standard Operating Procedure; EMS = Environmental Monitoring Section; EPA = Environmental Protection Agency; NA = not applicable

\subsection{SAMPLING AND ANALYSIS RESULTS}

The primary purpose of the MFV testing was to evaluate siphon operation in the MFV mode of operation. Therefore minimal sampling and analysis were conducted during Phase II MFV testing. The primary treatability aspects of TGSC-1 were addressed during Phase I testing and documented in the Phase I Report [Phifer, et al., 1998].

As detailed in the Phase I Report, several reactions alter the chemical composition of the water that passes through the GeoSiphon Cell:

- The corrosion of iron by water (i.e., the oxidation of the zero-valent iron and the reduction of water)

- The corrosion of iron by dissolved oxygen

- The reduction of the CVOCs, nitrates, and sulfates

- The precipitation of pyrite $\left(\mathrm{FeS}_{2}\right)$, ferrous carbonate $\left(\mathrm{FeCO}_{3}\right)$, and ferrous iron hydroxide $\left(\mathrm{Fe}(\mathrm{OH})_{2}\right)$

These reactions can significantly alter the chemistry of the treated water:

- Iron corrosion results in an oxidation/reduction (redox) potential decrease (Eh), a pH increase, oxygen depletion, the production of dissolved ferrous iron $\left(\mathrm{Fe}^{+2}\right)$ and hydrogen gas, and the subsequent precipitation of ferrous carbonate and ferrous hydroxide.

- TCE, cis-1,2-dichloroethylene ( $\mathrm{CDCE}$ ), carbon tetrachloride (CT), and chloroform (TCM) reduction results in ethene, ethane, methane, and chloride ions as final end products.

- Nitrate reduction results in the production of ammonium ions.

- Sulfate reduction results in the production of sulfide, and the subsequent precipitation of pyrite [Phifer, et al., 1998].

Gasses and dissolved gasses were not evaluated during Phase I testing.

\subsubsection{Field Parameters}

The field parameter analyses were performed to determine if the geochemical operation of TNX GeoSiphon Cell during the Phase II MFV testing was similar to that observed during the Phase I testing. Table 10 provides the $\mathrm{pH}$, dissolved oxygen (DO), Eh, specific conductance (SC), 
turbidity, and temperature data collected during the Phase II MFV testing. The date, time, and flow rate associated with each measurement, as well as the range of the parameter values collected during Phase I testing, are provided for comparison. Wells TCM-2 and TCM-4 represent untreated groundwater or influent conditions, and TGSC-1 and the SDP represent treated groundwater or effluent conditions. The SDP represents the treated groundwater or effluent after it has been transported through the siphon line. Field data show the general Eh decrease (oxidation/reduction potential) and $\mathrm{pH}$ increase associated with the zero-valent, ironenhanced, abiotic degradation of CVOCs. In fact, the $\mathrm{pH}$ increased to values slightly higher than the highest recorded Phase I pH value. Additionally, the Eh decreased to values at the lower end of the Phase I Eh values and was significantly lower than the average Phase I Eh of $-135 \mathrm{mV}$. During Phase I, the Eh decreased toward zero with increased flow rate and increased duration of operation. All the Phase II MFV test runs and associated field data represent short duration, intermittent operation of the cell or essentially start-up conditions. This may be the reason for the slight deviation from the Phase I range of values for $\mathrm{pH}$ and $\mathrm{Eh}$. Both influent and effluent dissolved oxygen values appear to have decreased from Phase I values. Specific conductance and turbidity measurements were not made during Phase I testing. The Phase II MFV specific conductance and turbidity measurements indicate that the effluent has less dissolved and suspended solids than the influent.

Overall, the field parameters indicate that the cell is operating geochemically as anticipated, and the slight deviations from the Phase I values may be due to the essentially start-up conditions of the Phase II MFV test runs. 
Table 10

Field Parameter Results ${ }^{1}$

\begin{tabular}{|c|c|c|c|c|}
\hline \multirow{4}{*}{$\begin{array}{l}\text { Sample } \\
\text { Location }\end{array}$} & Date & $4 / 7 / 99$ & $4 / 27 / 99$ & \multirow{4}{*}{$\begin{array}{l}\text { Phase I Range } \\
\text { of Values }\end{array}$} \\
\hline & Time $^{2}$ & $10: 44-11: 38$ & $10: 18-10: 55$ & \\
\hline & Flow (gpm) & $6.2-5.7$ & $4.4-5.1$ & \\
\hline & Parameter & \multicolumn{2}{|c|}{ Result } & \\
\hline TCM-2 & $\mathrm{pH}$ & 5.28 & 5.18 & $4.46-5.77$ \\
\hline TCM-4 & $\mathrm{pH}$ & 5.51 & 5.37 & - \\
\hline \multicolumn{2}{|c|}{ Average Influent $\mathrm{pH}$} & 5.40 & 5.28 & - \\
\hline TGSC-1 & $\mathrm{pH}$ & 9.84 & 9.56 & $7.79-9.42$ \\
\hline$\overline{\text { SDP }}$ & $\mathrm{pH}$ & 10.02 & 9.76 & - \\
\hline \multicolumn{2}{|c|}{ Average Effluent $\mathrm{pH}$} & 9.93 & 9.66 & - \\
\hline TCM-2 & $\mathrm{DO}, \mathrm{mg} / \mathrm{L}$ & 1.36 & 1.90 & $3.0-3.1$ \\
\hline TCM-4 & $\mathrm{DO}, \mathrm{mg} / \mathrm{L}$ & 0.69 & 1.16 & - \\
\hline \multicolumn{2}{|c|}{ Average Influent DO } & 1.02 & 1.53 & - \\
\hline TGSC-1 & $\mathrm{DO}, \mathrm{mg} / \mathrm{L}$ & 1.14 & 1.37 & 1.9 to 2.3 \\
\hline SDP & $\mathrm{DO}, \mathrm{mg} / \mathrm{L}$ & 0.94 & 1.07 & - \\
\hline \multicolumn{2}{|c|}{ Average Effluent DO } & 1.04 & 1.22 & - \\
\hline TCM-2 & Eh, mV & 481 & 474 & 393.3 to 456.6 \\
\hline TCM-4 & Eh, mV & $\overline{460}$ & $\overline{471}$ & - \\
\hline \multicolumn{2}{|c|}{ Average Influent Eh } & 470 & 472 & - \\
\hline TGSC-1 & Eh, mV & -410 & -404 & -8.6 to $-492^{3}$ \\
\hline$\overline{\text { SDP }}$ & Eh, mV & -412 & -405 & - \\
\hline \multicolumn{2}{|c|}{ Average Effluent Eh } & -411 & -404 & - \\
\hline$\overline{\text { TCM-2 }}$ & $\mathrm{SC}, \mu \mathrm{mho} / \mathrm{cm}$ & 0.158 & 0.160 & - \\
\hline TCM-4 & $\mathrm{SC}, \mu \mathrm{mho} / \mathrm{cm}$ & 0.168 & 0.152 & $\overline{-}$ \\
\hline \multicolumn{2}{|c|}{ Average Influent SC } & 0.163 & 0.156 & - \\
\hline TGSC-1 & $\mathrm{SC}, \mu \mathrm{mho} / \mathrm{cm}$ & 0.058 & 0.056 & - \\
\hline SDP & $\mathrm{SC}, \mu \mathrm{mho} / \mathrm{cm}$ & 0.056 & 0.054 & $\overline{-}$ \\
\hline \multicolumn{2}{|c|}{ Average Effluent SC } & 0.057 & 0.055 & - \\
\hline TCM-2 & Turbidity (NTU) & 6.54 & - & - \\
\hline TCM-4 & Turbidity (NTU) & 13.86 & - & - \\
\hline \multicolumn{2}{|c|}{ Average Influent Turbidity } & 10.20 & - & - \\
\hline TGSC-1 & Turbidity (NTU) & 1.42 & - & - \\
\hline SDP & Turbidity (NTU) & 1.25 & - & - \\
\hline \multicolumn{2}{|c|}{ Average Effluent Turbidity } & 1.34 & - & - \\
\hline TCM-2 & Temperature ${ }^{\circ} \mathrm{C}$ & 16.7 & 17.6 & $13.9-16.8$ \\
\hline TCM-4 & Temperature ${ }^{\circ} \mathrm{C}$ & 16.7 & 17.7 & - \\
\hline TGSC-1 & Temperature ${ }^{\circ} \mathrm{C}$ & 17.0 & 17.2 & $11.9-28.5$ \\
\hline SDP & Temperature ${ }^{\circ} \mathrm{C}$ & 17.9 & 18.0 & - \\
\hline
\end{tabular}


Notes to Table 10:

All Table 10 values were obtained utilizing field meters

${ }^{1}$ Analyses performed by SRTC Environmental Sciences and Technology Section

${ }^{2}$ TGSC-1 and SDP sampling period

${ }^{3}$ Average Phase I Eh was $-135 \mathrm{mV}$, and the Eh decrease toward zero with increased flow rate and increased duration of operation

$\mathrm{SDP}=$ siphon discharge point; $\mathrm{DO}=$ dissolved oxygen; $\mathrm{Eh}=$ redox potential; $\mathrm{SC}=$ specific conductance

\subsubsection{Chlorinated Volatile Organic Compounds}

The primary purpose of the CVOCs analyses were to ascertain that degradation was occurring, to ensure that the discharge TCE concentration was below $5 \mu \mathrm{g} / \mathrm{L}$, and to determine if the CVOCs de-gassed within the siphon line. Tables 11 and 12 present the TCE data for the MFV 2-inch continuous siphon line and MFV 2-inch upward leg to 1-1/4 -inch crest and downward leg siphon line test runs, respectively. The complete CVOC analytical results are provided in Appendix B. Wells TCM-2 and TCM-4 represent untreated groundwater or influent conditions. TGSC-1 and the SDP represent treated groundwater or effluent conditions. The SDP represents the treated groundwater or effluent after it has been transported through the siphon line.

Three different laboratories performed the analyses. Microseeps, Inc. and Shealy Environmental Services, Inc., both US EPA-certified laboratories, performed the analyses utilizing US EPAapproved methods (SW 846 Method 8021 and SW 846 Method 8260, respectively). The onsite Environmental Sciences and Technology Department (EST) analyses are screening level analyses, which were not corrected for the actual sample volume collected. The EST analyses were used for process control purposes because the analytical turnaround was quicker.

The influent TCE concentrations ranged from 41 to $51 \mu \mathrm{g} / \mathrm{L}$. The effluent TCE concentrations ranged from 2.7 to $3.0 \mu \mathrm{g} / \mathrm{L}$, which showed degradation was sufficient to reduce the influent TCE concentrations to below $5 \mu \mathrm{g} / \mathrm{L}$. The TGSC-1 value represents the inlet to the siphon line while the SDP value represents the outlet of the siphon line. There is no significant difference between the siphon line inlet (TGSC-1) and the outlet (SDP) TCE concentrations as shown in Tables 11 and 12. Therefore little, if any, TCE de-gassing occurred within the siphon line at the concentrations present. 
Table 11

TGSC-1 MFV 2-Inch Continuous Siphon Line

TCE Analytical Results

\begin{tabular}{|r|c|c|c|c||}
\hline Date & 4/7/99 & $4 / 7 / 99$ & $4 / 7 / 99$ & \multicolumn{1}{|c|}{$4 / 7 / 99$} \\
\hline Time & $8: 35 \mathrm{AM}$ & $9: 34 \mathrm{AM}$ & $10: 44 \mathrm{AM}$ & $11: 38 \mathrm{AM}$ \\
\hline Flow $(\mathrm{gpm})$ & $\sim 5.7$ & $\sim 4.3$ & $\sim 6.0$ & $\sim 5.2$ \\
\hline \multirow{3}{*}{ Laboratory } & \multicolumn{4}{|c|}{ Sample Location } \\
\cline { 2 - 5 } & TCM-2 & TCM-4 & TGSC-1 & \multicolumn{1}{c|}{ SDP } \\
\hline Microseeps, Inc. & 41 & 49 & 3 & 3 \\
\hline EST screening & 91.6 & 82.3 & 6 & 5.7 \\
\hline
\end{tabular}

Notes: All values in $\mu \mathrm{g} / \mathrm{L}$; EST $=$ Environmental Sciences and Technology Department (the CVOC analysis conducted by EST is a screening level of analysis); SDP $=$ Siphon Discharge Point

Table 12

TGSC-1 MFV 2-Inch Upward Leg to 1-1/4-Inch Crest and Downward Leg Siphon Line TCE Analytical Results

\begin{tabular}{|c|c|c|c|c|c|c|}
\hline Date & $4 / 27 / 99$ & $4 / 27 / 99$ & $4 / 27 / 99$ & $4 / 22 / 99$ & $4 / 26 / 99$ & $4 / 27 / 99$ \\
\hline Time & $8: 30 \mathrm{AM}$ & $9: 12 \mathrm{AM}$ & $10: 18 \mathrm{AM}$ & $1: 30 \mathrm{PM}$ & $12: 30 \mathrm{PM}$ & $\overline{10: 55 \mathrm{AM}}$ \\
\hline Flow (gpm) & $\sim 4.4$ & $\sim 4.7$ & \begin{tabular}{|l|}
$\sim 3.9$ \\
\end{tabular} & $\sim 1.3$ & $\sim 5.7$ & $\sim 4.4$ \\
\hline \multirow[b]{2}{*}{ Laboratory } & \multicolumn{6}{|c|}{ Sample Location } \\
\hline & \multicolumn{6}{|c|}{\begin{tabular}{c|c} 
Sample Location \\
TGSC-1 SDC
\end{tabular}} \\
\hline Microseeps, Inc. & 48 & 51 & 3 & & & 3 \\
\hline SES, Inc. & E & - & 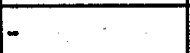 & 2.7 & $\overline{3}$ & \\
\hline EST screening & 73.8 & 62.8 & 4.7 & & & $\overline{4.8}$ \\
\hline
\end{tabular}

Notes: All values in $\mu \mathrm{g} / \mathrm{L} ;$ EST $=$ Environmental Sciences and Technology Department (the CVOC analysis conducted by EST is a screening level of analysis); SES, Inc. = Shealy Environmental Services, Inc. sampling and analysis conducted under the NPDES program; SDP $=$ Siphon Discharge Point

Although sufficient degradation occurred to reduce the influent TCE concentrations (41 to $51 \mu \mathrm{g} / \mathrm{L}$ ) to below $5 \mu \mathrm{g} / \mathrm{L}$, the effluent TCE concentrations of 2.7 to $3.0 \mu \mathrm{g} / \mathrm{L}$ were somewhat greater than would be anticipated from the Phase I results. During Phase I influent TCE concentrations of approximately $200 \mu \mathrm{g} / \mathrm{L}$ were reduced to approximately $4.5 \mu \mathrm{g} / \mathrm{L}$ at a flow rate of approximately $8 \mathrm{gpm}$, whereas influent concentrations of approximately $50 \mu \mathrm{g} / \mathrm{L}$ were reduced to approximately $3.0 \mu \mathrm{g} / \mathrm{L}$ at a flow rate of approximately $5 \mathrm{gpm}$. Table 13 provides all of the SDP results produced by US EPA-certified laboratories and approved methods and the anticipated TCE concentration based upon a correlation with flow, which was produced during Phase I testing [Phifer, et al., 1998]. This correlation was based upon a higher average inlet TCE concentration $(\sim 200 \mu \mathrm{g} / \mathrm{L})$ than existed during the Phase II MFV test runs (41 to $51 \mu \mathrm{g} / \mathrm{L}$ ); 
therefore, it is not entirely applicable. As shown, the anticipated TCE concentrations from this correlation are less than the measured TCE concentrations [Phifer, 1999b].

Table 13

TCE Discharge Results from the Siphon Discharge Point (SDP)

\begin{tabular}{|c|c|c|c|c|}
\hline $\begin{array}{c}\text { Sample } \\
\text { Date }\end{array}$ & $\begin{array}{c}\text { Samplers and } \\
\text { Laboratory }\end{array}$ & $\begin{array}{c}\text { Approximate } \\
\text { Flow Rate } \\
(\mathrm{gpm})\end{array}$ & $\begin{array}{c}\text { Measured } \\
\text { TCE } \\
\text { Concentration } \\
(\mu \mathrm{g} / \mathrm{L})\end{array}$ & $\begin{array}{c}\text { Anticipated } \\
\text { TCE } \\
\text { Concentration } \\
(\mu \mathrm{g} / \mathrm{L})\end{array}$ \\
\hline $4 / 7 / 99$ & $\begin{array}{c}\text { Microseeps, } \\
\text { Inc. }\end{array}$ & $\sim 5.2$ & 3 & 1.2 \\
\hline $4 / 22 / 99$ & SES, Inc. & $\sim 1.3$ & 2.7 & 0.2 \\
\hline $4 / 26 / 99$ & SES, Inc. & $\sim 5.7$ & 3 & 1.5 \\
\hline $4 / 27 / 99$ & $\begin{array}{c}\text { Microseeps, } \\
\text { Inc. }\end{array}$ & $\sim 4.4$ & 3 & 0.8 \\
\hline
\end{tabular}

'Anticipated TCE concentrations based upon a correlation with flow produced during Phase I testing from TCE discharge data from laboratories using US EPA-approved methods or equivalent as documented in Phifer, et. al., $1998\left(\mathrm{TCE}(\mu \mathrm{g} / \mathrm{L})=10^{((0.193 * \mathrm{Q}(\mathrm{gpm}))-0.9207)}\right)$ Notes: SES, Inc. $=$ Shealy Environmental Services, Inc. sampling and analysis conducted under the NPDES program

[Phifer, 1999b]

The deviation between the measured TCE discharge concentrations and the anticipated TCE discharge concentrations based upon Phase I results could result from one or more of the following:

- Normal system start-up fluctuations (During the MFV testing, the system operated for durations of four to thirteen hours per day over two- to four-day periods at highly variable flow rates. This means that the system was continuously operated in a start-up mode during MFV testing.)

- Inapplicability of the Phase I correlation due to changed conditions such as formation contaminant distribution, etc.

- Decrease in the apparent first order rate constant due to a decrease in inlet TCE concentrations (TCE degradation by granular cast iron appears to be a surface-activated reaction, which is mass transfer limited. Therefore, a reduction in inlet concentration could result in a decrease in the apparent first order rate constant.)

- Iron deactivation, probably due to precipitation fouling

Iron deactivation due to precipitation fouling is the most problematic possible explanation for this deviation. To fully evaluate the potential for iron deactivation due to precipitation fouling as the cause of the higher than anticipated TCE discharge concentrations, a review of the specific 
capacity over time was conducted. Specific capacity is the flow rate per unit drawdown in a well and is a measure of the head loss or ease of water flow through a combination of the formation, gravel pack, and screen. In the case of TGSC-1, specific capacity measures head loss through a combination of the aquifer formation and the cell (i.e., GeoNet with filter fabric, granular cast iron, and screen). Higher specific capacity measurements are indicative of less head loss through the components and an increased ease of flow. Generally, specific capacity gradually decreases with an increase in flow rate. This is due to the higher associated velocities, which produce greater head losses through the components. Therefore, the measurement of specific capacity over time at a constant flow rate provides an indication of whether or not flow restrictions are occurring in one or more of these components (i.e., the formation, GeoNet with filter fabric, granular cast iron, and/or screen). Testing to date has not had the specific objective of producing specific capacity measurements over time, much less at a constant flow rate. However, the necessary data was available from both previous GeoSiphon reports and this MFV testing to produce a limited number of high quality, specific capacity measurements. Table 14 presents the available specific capacity measurements. The longer the duration of measurement associated with each specific capacity measurement, the more likely the measurement represents an equilibrium measurement. All the specific capacities have been normalized to a wetted screen length of $14 \mathrm{ft}$ so that they are directly comparable. Appendix $\mathrm{C}$ provides the detailed data and calculations associated with these specific capacity measurements [Phifer et al., 1998; Phifer, et al., 1999a; Phifer, 1999b].

Table 14

Specific Capacity Measurements

\begin{tabular}{||c|c|c|c|c|c|c||}
\hline Date & $\begin{array}{c}\text { Duration of } \\
\text { Measurement } \\
\text { (min) }\end{array}$ & $\begin{array}{c}\text { Flow Rate } \\
(\mathrm{gpm})\end{array}$ & $\begin{array}{c}\text { TGSC-1 } \\
\text { Drawdown } \\
\text { (ft) }\end{array}$ & $\begin{array}{c}\text { TGSC-1 } \\
\text { Water } \\
\text { Elevation } \\
\text { (ft-msl) }\end{array}$ & $\begin{array}{c}\text { Wetted } \\
\text { Screen } \\
\text { Length } \\
\text { (ft) }\end{array}$ & $\begin{array}{c}\text { Normalized } \\
\text { Specific } \\
\text { Capacity } \\
\text { (gpm/ft) }\end{array}$ \\
\hline $8 / 10 / 97$ & 1380 & 0.65 & 0.22 & 92.11 & 14 & 3.015 \\
\hline $8 / 27 / 98$ & 9780 & 2.44 & 1.19 & 91.95 & 14 & 2.049 \\
\hline $4 / 27 / 99$ & 240 & 4.36 & 2.56 & 89.70 & 12.8 & 1.864 \\
\hline
\end{tabular}

[Phifer, 1999b]

Table 14 shows that the normalized specific capacities have either decreased over time (i.e., time since cell installation), which may be indicative of precipitation fouling; or they have decreased with increasing flow rate, which is a typical specific capacity response to increasing flow rates as outlined above. Currently, sufficient data does not exist to determine whether the specific capacity decrease shown in Table 14 is associated with time (i.e., precipitation fouling) or flow rate increase. Therefore, future operation of the TNX GeoSiphon Cells should include the measurement of specific capacity at similar flow rates for comparison to the Table 14 values to determine if negative trends are developing [Phifer, 1999b]. 
Continued reductions in specific capacity over time, which are not flow-rate dependent, are indicative of increasing restrictions to flow within the formation, GeoNet with filter fabric, granular cast iron, and/or screen. Precipitation within the formation could be occurring during periods when the GeoSiphon Cell is not operating. During these periods of no operation, groundwater flows from the formation into the granular cast iron and back into the formation. When the groundwater enters the granular cast iron, the $\mathrm{pH}$ increases, the Eh decreases, and the level of ferrous iron increases. When this treated groundwater reenters the formation, the $\mathrm{pH}$ will decrease, the Eh will increase, and ferric hydroxide may precipitate within the formation pores, resulting in a decrease in specific capacity. As documented within Phifer et al., 1998, calcium carbonate, ferrous hydroxide, and magnetite are acknowledged precipitates that can occur within the granular cast iron, particularly where the groundwater first enters the iron. Precipitation within the GeoNet with filter fabric is considered less likely than within the formation or iron since the GeoNet should not promote significant geochemical changes itself. Precipitation of predominantly ferrous hydroxide on the screen is possible [Phifer, 1999b].

Decreases in specific capacity within the granular cast iron may not be only indicative of a reduction of TCE degradation rates caused by precipitation deactivation of the granular cast iron. Such decreases also impact the maximum flow rate that the siphon can pull. The more head loss that occurs within the formation and cell, the less head available to drive the flow within the siphon line. Therefore, less flow occurs in the siphon line [Phifer, 1999b].

In summary, TCE discharge results from analyses using US EPA-certified methods over time and specific capacity at a near constant flow rate over time needs to be tracked to determine if negative trends are developing. The TCE discharge results obtained from US EPA-certified methods during the Phase II MFV testing were at slightly higher than anticipated levels, but still below the MCL of $5 \mu \mathrm{g} / \mathrm{L}$. There are several previously discussed possible reasons for this deviation, with precipitation fouling being the most problematic. The specific capacity decrease shown in Table 14 is attributable to time or to increasing flow rates. The current data is insufficient to make an absolute determination of which is the controlling factor. If the controlling factor is time, then precipitation fouling is the most likely cause of the specific capacity decrease [Phifer, 1999b]. Additionally determination of the first order rate constant from sampling and analyses of the TGSC-1 sampling ports, as performed during Phase I testing [Phifer, et al., 1998], should be performed over time to assist in the evaluation of potential iron deactivation.

\subsubsection{Dissolved Gasses and Gasses}

The primary purpose of the dissolved-gas and gas analyses was two-fold: to determine the changes that occur in gas composition and quantity as a result of treatment by the iron and transport with the siphon line and to estimate the rate of de-gassing and type of gasses being degassed. 


\subsubsection{Dissolved gasses in Water}

Table 15 presents the average dissolved-gas concentrations from water samples collected from wells TCM-2 and TCM-4, TGSC-1, and the SDP. Sampling and analysis for these dissolved-gas concentrations were conducted during testing of both the continuous 2-inch and the 2-inch to 1$1 / 4$-inch siphon line configurations. Table 15 data presents the average of all four measurements produced for both siphon line configurations at a particular sample location. As shown in Appendix D, the four measurements for each of the dissolved gasses are fairly consistent except for the Microseeps, Inc., values discussed below. Wells TCM-2 and TCM-4 represent untreated groundwater or influent conditions, and TGSC-1 and the SDP represent treated groundwater or effluent conditions. The SDP represents the treated groundwater or effluent after it has been transported through the siphon line. The table also presents the calculated dissolved-gas concentrations in water in equilibrium with the atmosphere based upon Henry's law. The complete dissolved-gas analytical results, the calculation of the dissolved-gas averages, and the Henry's law calculations for dissolved-gas equilibrium with the atmosphere are provided in Appendix D. 
Table 15

Dissolved-gas Average Analytical Results

\begin{tabular}{|c|c|c|c|c|c|}
\hline Location & $\begin{array}{c}\mathrm{N}_{2} \\
(\mathrm{mg} / \mathrm{L})\end{array}$ & $\begin{array}{c}\mathrm{O}_{2} \\
(\mathrm{mg} / \mathrm{L})\end{array}$ & $\begin{array}{c}\text { Field } \\
\mathrm{O}_{2} \\
(\mathrm{mg} / \mathrm{L})\end{array}$ & $\begin{array}{c}\mathrm{CO}_{2} \\
(\mathrm{mg} / \mathrm{L})\end{array}$ & $\begin{array}{c}\mathrm{CO} \\
(\mathrm{mg} / \mathrm{L})\end{array}$ \\
\hline Average TCM-2 & 15.39 & 40.52 & 1.63 & 91.32 & $<0.40$ \\
\hline Average TCM-4 & 14.72 & 5.57 & 0.93 & 109.53 & $<0.40$ \\
\hline Average Groundwater & 15.05 & 5.04 & 1.28 & 100.42 & $<0.40$ \\
\hline Average TGSC-1 & 7.81 & 2.82 & 1.26 & 1.56 & $<0.40$ \\
\hline Average SDP & 6.34 & $\overline{3.63}$ & 1.01 & 1.51 & $<0.40$ \\
\hline Average Treated & 7.26 & 3.08 & 1.14 & 1.54 & $<0.40$ \\
\hline$\%$ Change 1 & $-51.8 \%$ & $-38.9 \%$ & $-10.9 \%$ & $-89.4 \%$ & - \\
\hline Equilibrium with Atmosphere & 16.11 & 10.45 & 10.45 & 0.60 & $\begin{array}{c}1.7 \mathrm{E}-06 \text { to } \\
2.9 \mathrm{E}-05\end{array}$ \\
\hline Detection Limits & 0.40 & 0.15 & 0.01 & 0.60 & 0.40 \\
\hline Location & $\begin{array}{c}\mathrm{CH}_{4} \\
(\mathrm{mg} / \mathrm{L})\end{array}$ & $\begin{array}{c}\mathrm{H}_{2} \\
(\mathrm{mg} / \mathrm{L})\end{array}$ & $\begin{array}{c}\mathrm{C}_{2} \mathrm{H}_{6} \\
(\mathrm{mg} / \mathrm{L})\end{array}$ & $\begin{array}{c}\mathrm{C}_{2} \mathrm{H}_{4} \\
(\mathrm{mg} / \mathrm{L})\end{array}$ & \\
\hline Average TCM-2 & $6.20 \mathrm{E}-05$ & $4.81 \mathrm{E}-06$ & $<5.0 \mathrm{E}-06$ & $6.45 \mathrm{E}-05$ & \\
\hline Average TCM-4 & $6.60 \mathrm{E}-04$ & $4.43 \mathrm{E}-06$ & $5.25 \mathrm{E}-06$ & $5.58 \mathrm{E}-05$ & \\
\hline Average Groundwater & $3.61 \mathrm{E}-04$ & $4.62 \mathrm{E}-06$ & $5.13 \mathrm{E}-06$ & $6.02 \mathrm{E}-05$ & \\
\hline Average TGSC-1 & 0.55 & 1.30 & $2.59 \mathrm{E}-03$ & $5.79 \mathrm{E}-04$ & \\
\hline Average SDP & 0.72 & 1.45 & $2.85 \mathrm{E}-03$ & $6.70 \mathrm{E}-04$ & \\
\hline Average Treated & 0.64 & 1.38 & $2.72 \mathrm{E}-03$ & $6.24 \mathrm{E}-04$ & \\
\hline$\%$ Change $^{1}$ & $1.8 \mathrm{E}+06 \%$ & $3.0 \mathrm{E}+07 \%$ & $52,000 \%$ & $630 \%$ & \\
\hline Equilibrium with Atmosphere & $5.1 \mathrm{E}-05$ & $8.9 \mathrm{E}-07$ & $\begin{array}{c}.2 \mathrm{E}-09 \text { to } \\
6.2 \mathrm{E}-06\end{array}$ & $\begin{array}{c}1.3 \mathrm{E}-07 \text { to } \\
1.3 \mathrm{E}-04\end{array}$ & \\
\hline Detection Limits & $1.5 \mathrm{E}-05$ & $6.05 \mathrm{E}-08$ & $5.0 \mathrm{E}-06$ & $5.0 \mathrm{E}-06$ & \\
\hline
\end{tabular}

Notes: Each of the average TCM-2, TCM-4, TGSC-1, and SDP valves include four fairly consistent measurements except for the Microseeps, Inc. oxygen values as outlined below. Therefore each of the Average Groundwater and Average Treated values include eight fairly consistent measurements. See Appendix $\mathrm{D}$ for the raw data.

$\mathrm{CH}_{4}=$ methane; $\mathrm{C}_{2} \mathrm{H}_{6}=$ ethane; $\mathrm{C}_{2} \mathrm{H}_{4}=$ ethylene; $\mathrm{SDP}=$ siphon discharge point

$1 \%$ Change $=(($ Average Groundwater - Average Treated $) \div$ Average Groundwater $) \times 100$

Table 16 provides the detailed oxygen data collected by Microseeps, Inc., utilizing the Bubble Strip Method, and by EST, utilizing a field DO meter. The following are observations concerning the Microseeps, Inc. oxygen data:

- According to Microseeps, Inc., the Bubble Strip Method (SOP AM19) for oxygen generally produces higher oxygen values than are produced by the conventional 
Winkler method or by DO meters.

- According to Microseeps, Inc., argon co-elutes with oxygen in the Microseeps, Inc. Bubble Strip Method (SOP AM19).

- According to Microseeps, Inc., the Bubble Strip Method works by bringing the dissolved gasses in water into equilibrium with an ambient air bubble. Any variation in gaseous component concentrations in the ambient air bubble from the assumed ambient air concentrations will impact the dissolved-gas concentrations produced by the Bubble Strip Method.

- According to Microseeps, Inc., the maximum standard deviation produced from the Bubble Strip Method is $\pm 11 \%$.

- The calculated dissolved oxygen concentration in equilibrium with the atmosphere, based upon Henry's law at $17^{\circ} \mathrm{C}$, is $10.45 \mathrm{mg} / \mathrm{L}$. Generally, groundwater concentrations of dissolved oxygen are significantly less than the Henry's law equilibrium value since there are typically no reactions that produce oxygen but there are several reactions that consume oxygen. The four 4/27/99 Microseeps samples produced oxygen values of 8.66 to $10.19 \mathrm{mg} / \mathrm{L}$, which are significantly higher than typically seen in groundwater. They are not considered representative of the conditions at TNX.

- In two instances, duplicate $4 / 27 / 99$ Microseeps, Inc. oxygen values varied significantly (i.e., 9.26 versus $2.72 \mathrm{mg} / \mathrm{L}$ and 2.15 versus $9.82 \mathrm{mg} / \mathrm{L}$ ), indicating a sampling or analytical error.

Due to the above observations, the 4/27/99 Microseeps, Inc. oxygen data are not considered representative of the conditions at TNX. Additionally, since the Microseeps, Inc. method typically produces oxygen values greater than the conventional Winkler method or DO meter, only the field oxygen values will be utilized in further discussions. All other Microseeps, Inc. dissolved-gas data appear to be generally reasonable and consistent. 
Table 16

Microseeps Versus Field Oxygen Values

\begin{tabular}{|c|c|c|c|c|}
\hline Location & $\begin{array}{c}4 / 7 / 99 \\
\text { Microseeps } \\
\mathrm{O}_{2} \\
(\mathrm{mg} / \mathrm{L})\end{array}$ & $\begin{array}{c}4 / 7 / 99 \\
\text { Field } \\
\mathrm{O}_{2} \\
(\mathrm{mg} / \mathrm{L})\end{array}$ & $\begin{array}{c}4 / 27 / 99 \\
\text { Microseeps } \\
\mathrm{O}_{2} \\
(\mathrm{mg} / \mathrm{L})\end{array}$ & $\begin{array}{c}4 / 27 / 99 \\
\text { Field } \\
\mathrm{O}_{2} \\
(\mathrm{mg} / \mathrm{L})\end{array}$ \\
\hline TCM-2 & 3.16 & 1.36 & 9.26 & 1.9 \\
\hline TCM-2A & 2.93 & & 2.72 & \\
\hline TCM-4 & 1.59 & 0.69 & 10.19 & 1.16 \\
\hline TCM-4A & 1.83 & & 8.66 & \\
\hline TGSC-1 & 3.1 & 1.14 & 2.60 & 1.37 \\
\hline TGSC-1A & 3.52 & & 2.07 & \\
\hline SDP-1 & 1.31 & 0.94 & 2.15 & 1.07 \\
\hline SDP-1A & 1.22 & & 9.82 & \\
\hline Detection Limit & 0.15 & 0.01 & 0.15 & 0.01 \\
\hline Equilibrium with & 10.45 & 10.45 & 10.45 & 10.45 \\
Atmosphere & & & & \\
\hline
\end{tabular}

Notes: SDP $=$ siphon discharge point

As shown in Table 15, the average groundwater dissolved-nitrogen concentration is near the calculated dissolved concentration in equilibrium with the atmosphere. This indicates that nitrogen is, essentially, conservative relative to fate and transport within the subsurface at TNX. The average groundwater dissolved oxygen concentration (field value) is approximately twelve percent that of the calculated dissolved concentration in equilibrium with the atmosphere. This indicates that aerobic microorganisms are consuming oxygen within the subsurface at TNX. Additionally, the average groundwater, dissolved-carbon dioxide concentration is greater than the calculated dissolved concentration in equilibrium with the atmosphere. The elevated carbon dioxide level is due to aerobic microorganism respiration and the presence of carbonates in the subsurface. The average groundwater dissolved-methane and hydrogen concentrations are greater than the calculated dissolved concentration in equilibrium with the atmosphere. This indicates that anaerobic microorganisms produce methane and hydrogen within the subsurface at TNX.

Groundwater flow and treatment through the TGSC-1 produces several changes in the dissolved gasses present. The dissolved-nitrogen concentration decreased from an average of approximately $15 \mathrm{mg} / \mathrm{L}$ in the groundwater (average groundwater concentration from Table 15) to approximately $7 \mathrm{mg} / \mathrm{L}$ in the treated effluent (average treated concentration from Table 15). It is assumed that this decrease in nitrogen is caused by the reduction of nitrogen to the ammonia ion by the zero-valent iron, as follows:

$$
3 \mathrm{Fe}^{\mathrm{o}}+\mathrm{N}_{2}+8 \mathrm{H}^{+}=2 \mathrm{NH}_{4}^{+}+3 \mathrm{Fe}^{+2}
$$


The dissolved oxygen concentration decreases from an average of approximately $1.3 \mathrm{mg} / \mathrm{L}$ in the groundwater to approximately $1.1 \mathrm{mg} / \mathrm{L}$ in the treated effluent. This decrease is due to the corrosion of iron by oxygen, which results in dissolved oxygen gas depletion as follows:

$$
2 \mathrm{Fe}^{\mathrm{o}}+\mathrm{O}_{2} \text { (aq.) }+4 \mathrm{H}^{+}=2 \mathrm{Fe}^{+2}+2 \mathrm{H}_{2} \mathrm{O}
$$

The dissolved-carbon dioxide concentration decreases from an average of approximately 100 $\mathrm{mg} / \mathrm{L}$ in the groundwater to approximately $1.5 \mathrm{mg} / \mathrm{L}$ in the treated effluent. This decrease is assumed to be the result of the following three processes:

- The shift of the dominant carbonate species from carbonic acid $\left(\mathrm{H}_{2} \mathrm{CO}_{3}\right)$ to bicarbonate $\left(\mathrm{HCO}_{3}{ }^{\circ}\right)$ within an essentially closed system due to the $\mathrm{pH}$ increase from approximately 5.3 to approximately 9.8 (see Table 9 for the $\mathrm{pH}$ changes):

$$
\mathrm{CO}_{2} \text { (g) } \leftrightarrow \mathrm{CO}_{2} \text { (aq.) }+\mathrm{H}_{2} \mathrm{O} \leftrightarrow \mathrm{H}_{2} \mathrm{CO}_{3} \text { (aq.) } \leftrightarrow \mathrm{HCO}_{3}^{-}+\mathrm{H}^{+} \leftrightarrow \mathrm{CO}_{3}^{-2}+2 \mathrm{H}^{+}
$$

- Precipitation of ferrous, calcium, and/or magnesium carbonates, as follows:

$$
\begin{aligned}
& \mathrm{Fe}^{+2}+\mathrm{HCO}_{3}^{-}=\mathrm{FeCO}_{3}+\mathrm{H}^{+} \\
& \mathrm{Ca}^{+2}+\mathrm{HCO}_{3}^{-}=\mathrm{CaCO}_{3}+\mathrm{H}^{+} \\
& \mathrm{Mg}^{+2}+\mathrm{HCO}_{3}^{-}=\mathrm{MgCO}_{3}+\mathrm{H}^{+}
\end{aligned}
$$

- Reduction of carbon dioxide to methane by the zero-valent iron, as follows:

$$
4 \mathrm{Fe}^{\mathrm{o}}+\mathrm{CO}_{2} \text { (aq.) }+8 \mathrm{H}^{+}=\mathrm{CH}_{4}+2 \mathrm{H}_{2} \mathrm{O}+4 \mathrm{Fe}^{+2}
$$

The dissolved-methane concentration increases from an average of approximately $0.00036 \mathrm{mg} / \mathrm{L}$ in the groundwater to approximately $0.64 \mathrm{mg} / \mathrm{L}$ in the treated effluent. This increase is due to the reduction of carbon dioxide to methane by the zero-valent iron, as follows:

$$
4 \mathrm{Fe}^{\mathrm{o}}+\mathrm{CO}_{2} \text { (aq.) }+8 \mathrm{H}^{+}=\mathrm{CH}_{4}+2 \mathrm{H}_{2} \mathrm{O}+4 \mathrm{Fe}^{+2}
$$

Methane is a byproduct from the zero-valent iron reduction of carbon tetrachloride. However the carbon tetrachloride influent concentration (TCM-2 and TCM-4) is less than $5 \mu \mathrm{g} / \mathrm{L}$ (see Appendix B for the carbon tetrachloride data). The carbon tetrachloride influent concentration is not sufficient to produce the increase in methane concentrations recorded.

The dissolved hydrogen concentration increases from an average of approximately 0.0000046 $\mathrm{mg} / \mathrm{L}$ in the groundwater to $1.4 \mathrm{mg} / \mathrm{L}$ in the treated effluent. This increase is due to the corrosion of iron by water and subsequent hydrogen gas generation:

$$
\mathrm{Fe}^{\mathrm{o}}+2 \mathrm{H}_{2} \mathrm{O}=\mathrm{Fe}^{+2}+2 \mathrm{OH}^{-}+\mathrm{H}_{2} \text { (aq./g) }
$$

The dissolved-ethane and ethylene concentrations increased from an average of 0.000003 and $0.00009 \mathrm{mg} / \mathrm{L}$, respectively, in the groundwater to 0.003 and $0.0006 \mathrm{mg} / \mathrm{L}$, respectively, in the 
treated effluent. This increase is due to the reduction of TCE to ethane and ethylene by the zerovalent iron, as follows:

$$
\begin{aligned}
& 4 \mathrm{Fe}^{\circ}+\mathrm{C}_{2} \mathrm{HCl}_{3}+5 \mathrm{H}^{+}=4 \mathrm{Fe}^{+2}+\mathrm{C}_{2} \mathrm{H}_{6}+3 \mathrm{Cl}^{-} \text {(ethane) } \\
& 3 \mathrm{Fe}^{\circ}+\mathrm{C}_{2} \mathrm{HCl}_{3}+3 \mathrm{H}^{+}=3 \mathrm{Fe}^{+2}+\mathrm{C}_{2} \mathrm{H}_{4}+3 \mathrm{Cl}^{-} \text {(ethylene) }
\end{aligned}
$$

A comparison between the Table 15 TGSC-1 and the SDP dissolved-gas values reveals no consistent pattern of difference between the two locations. The TGSC-1 values represent treated effluent prior to transport through the siphon line, and the SDP values represent treated effluent after transport through the siphon line. If significant de-gassing relative to the dissolved-gas concentrations were occurring, a decrease in dissolved-gas concentrations would be anticipated between TGSC-1 and SDP. Therefore, it appears the de-gassing that is occurring is insignificant relative to the dissolved-gas concentrations (i.e., the bulk of the gasses remain dissolved, but sufficient de-gassing occurs to impact the siphon line operation).

\subsubsection{Siphon Crest Accumulated Gas}

In addition to the dissolved-gas sampling and analysis, a one-time siphon crest accumulated gasphase sample and duplicate were taken and analyzed during testing of the 2- to 1-1/4-inch siphon line configuration. Table 17 provides the average results of these analyses, in addition to the Phase II single-cell average results from August 24, 1998 [Phifer, et al., 1999a]. The complete gas analytical results are provided in Appendix D. Table 17 shows a considerable difference between the August 24, 1998, and the April 27, 1999, results. The April 27, 1999, results appear to be much closer to atmospheric conditions, with significantly less methane and hydrogen than in the August 24, 1998, results.

Table 17

\begin{tabular}{|c|c|c|c|}
\hline \multirow[b]{2}{*}{ Parameter } & \multicolumn{2}{|c|}{ Date / Location } & \multirow[b]{2}{*}{$\begin{array}{l}\text { Detection } \\
\text { Limits }\end{array}$} \\
\hline & $\begin{array}{c}\text { 8/24/98 } \\
\text { Air } \\
\text { Chamber }\end{array}$ & $\begin{array}{c}\text { 4/27/99 } \\
\text { Siphon } \\
\text { Crest }^{2}\end{array}$ & \\
\hline $\mathrm{N}_{2}(\% / \mathrm{V})$ & 46.25 & 75.95 & $0.04 \%$ \\
\hline $\mathrm{O}_{2}(\% / \mathrm{V})$ & 4.88 & 22.53 & $0.02 \%$ \\
\hline $\mathrm{CO}_{2}(\% / \mathrm{V})$ & $<0.01$ & 0.07 & $0.02 \%$ \\
\hline $\mathrm{CO}(\% / \mathrm{V})$ & $<0.01$ & $<0.02$ & $0.02 \%$ \\
\hline $\mathrm{CH}_{4}(\% / \mathrm{V})$ & 1.97 & 0.09 & 0.04 PPMV \\
\hline $\mathrm{H}_{2}(\% / \mathrm{V})$ & 40.99 & 5.82 & $0.02 \mathrm{PPMV}$ \\
\hline $\mathrm{C}_{2} \mathrm{H}_{6}(\% / \mathrm{V})$ & $4.18 \mathrm{E}-03$ & $1.02 \mathrm{E}-04$ & $0.01 \mathrm{PPMV}$ \\
\hline $\mathrm{C}_{2} \mathrm{H}_{4}(\% / \mathrm{V})$ & $6.13 \mathrm{E}-04$ & $1.45 \mathrm{E}-05$ & $0.01 \mathrm{PPMV}$ \\
\hline
\end{tabular}

Air Chamber / Siphon Crest Gas Average Analytical Results 
Notes to Table 17:

${ }^{1}$ Phifer, et al., 1999a

${ }^{2}$ Siphon crest average accumulated gas-phase concentrations

Table 18 compares the SDP average dissolved gas in water concentrations from Table 15, the siphon crest average accumulated gas-phase concentrations from Table 17, and the typical atmospheric air concentrations for nitrogen, oxygen, methane, and hydrogen. The following observations can be made concerning a comparison of the Table 18 data:

- The average dissolved gas in water concentrations from the SDP are not consistent with the average accumulated gas-phase concentrations from the siphon crest (i.e., the gasses dissolved in the water cannot produce a gas with the composition reported for the siphon crest).

- The nitrogen and oxygen from the siphon crest average accumulated gas-phase are essentially at atmospheric levels. According to Microseeps, the sampling and analytical techniques utilized produce data with a maximum standard deviation of $11 \%$, which places the nitrogen and oxygen data within the standard deviation of atmospheric levels.

[Phifer, 1999b]

Table 18

Dissolved Gas in Water, Crest Gas-phase, and Atmospheric Comparison

\begin{tabular}{|c|c|c|c||}
\hline Gas & $\begin{array}{c}\text { Siphon Discharge Point } \\
\text { Average Dissolved } \\
\text { Gas in Water } \\
\text { Concentrations } \\
(\mathrm{mg} / \mathrm{L})\end{array}$ & $\begin{array}{c}\text { Siphon Crest } \\
\text { Average Accumulated } \\
\text { Gas-phase } \\
\text { Concentrations } \\
\text { (\%/ Volume) }\end{array}$ & $\begin{array}{c}\text { Typical } \\
\text { Atmospheric Air } \\
\text { Concentrations } \\
\text { (\%/Volume) }\end{array}$ \\
\hline Nitrogen & 6.34 & 75.95 & 78.084 \\
\hline Oxygen ${ }^{4}$ & 1.01 & 22.53 & 20.9476 \\
\hline Methane & 0.72 & 0.09 & 0.0002 \\
\hline Hydrogen & 1.45 & 5.82 & 0.00005 \\
\hline Total & - & 104.38 & 99.03 \\
\hline
\end{tabular}

${ }^{1}$ SDP average dissolved gas concentrations from Table 15. These were water samples. This represents the average of four consistent measurements.

${ }^{2}$ Siphon crest average accumulated gas-phase concentrations from Table 17. These were gasphase samples.

${ }^{3}$ Lide, 1998

${ }^{4}$ SDP average dissolved gas concentration for oxygen is the field valve from Table 15 . These were water samples. This represents the average of two consistent measurements.

[Phifer, 1999b] 
Due to the similarity of the Table 18 siphon crest gas-phase and typical atmospheric nitrogen and oxygen concentrations and the apparent discrepancy between the siphon crest gas-phase and SDP dissolved gas data, the following analyses of the data were performed:

- Determination of the gas-phase concentrations that would be in equilibrium with the SDP average dissolved gas concentrations in water using Henry's law.

- Determination of the required mixture ratio of atmospheric air to the above equilibrium gas-phase concentration (Henry's law) to produce the siphon crest average accumulated gas-phase concentrations of Table 18. This will show if there is a consistent ratio between the two, which is indicative of mixing.

Table 19 provides the results of these analyses. The calculated equilibrium gas-phase concentrations presented in Table 19 were calculated from the Table 18 SDP average dissolved gas in water concentrations and the associated Henry's law constant at $17^{\circ} \mathrm{C}$ and then normalized to $100 \%$. The complete Henry's law calculations are provided in Appendix D. The Table 18 siphon crest average accumulated gas concentrations are reproduced in Table 19 for ease of comparison. The 11:1 gas mixture concentrations presented in Table 19 represent the concentration of the mixture produced by 11 parts of atmospheric air to 1 part of the calculated equilibrium gas-phase. The previous average air chamber gas concentrations presented in Table 19 are from the initial air chamber sampling conducted on 8/24/98 during the Phase II single-cell testing [Phifer, et al., 1999a; Phifer, 1999b].

Table 19

Gas Data Analyses:

Equilibrium and 11:1 Mixture Comparisons

\begin{tabular}{|c|c|c|c|c|c|}
\hline Gas & $\begin{array}{c}\text { Calculated } \\
\text { Equilibrium } \\
\text { Gas-phase } \\
\text { Concentrations }{ }^{1} \\
\text { (\%/Volume) }\end{array}$ & $\begin{array}{c}\text { Siphon Crest } \\
\text { Average } \\
\text { Accumulated } \\
\text { Gas-phase } \\
\text { Concentrations } \\
\text { (\%/ Volume) }\end{array}$ & $\begin{array}{c}\text { Typical } \\
\text { Atmospheric Air } \\
\text { Concentrations }{ }^{3} \\
(\% / \text { Volume })\end{array}$ & $\begin{array}{c}11: 1 \text { Gas } \\
\text { Mixture } \\
\text { Concentrations }{ }^{4} \\
\text { (\%/ Volume) }\end{array}$ & $\begin{array}{c}8 / 24 / 98 \\
\text { Air Chamber } \\
\text { Gas } \\
\text { Concentrations } \\
\text { (\%/ Volume) }\end{array}$ \\
\hline Nitrogen & 26.18 & 75.95 & 78.084 & 73.76 & 46.25 \\
\hline Oxygen & 1.72 & 22.53 & 20.9476 & 19.35 & 4.88 \\
\hline Methane & 2.41 & 0.09 & 0.0002 & 0.20 & 1.97 \\
\hline Hydrogen & 69.70 & 5.82 & 0.00005 & 5.81 & 40.99 \\
\hline Total & 100.00 & 104.38 & 99.02 & 99.10 & 94.08 \\
\hline
\end{tabular}

${ }^{1}$ See Appendix $\mathrm{D}$ for the detailed calculation

${ }^{2}$ Siphon crest average accumulated gas-phase concentrations from Table 17

${ }^{3}$ Lide, 1998

${ }^{4}[(11 \times$ Atmospheric Air Concentration $)+($ Calculated Equilibrium Gas-phase Concentration $)] \div 12$

${ }^{5}$ Phifer, et al., 1999a

[Phifer, 1999b] 
The calculated equilibrium gas-phase concentrations represent the gas-phase concentrations, which should be in equilibrium with the SDP average dissolved gas concentrations of Table 18. The SDP average dissolved gas concentration are considered representative of actual dissolved conditions since they are the average of four consistent measurements. If no atmospheric air leaked into the siphon line, then the calculated equilibrium gas-phase concentrations should be equivalent to the siphon crest average accumulated gas-phase concentrations. However, they are not equivalent. This indicates that atmospheric air did in fact leak into the siphon line or into the associated priming line. This leak could have occurred only during the sampling event itself or potentially throughout testing of the 2 to $1-1 / 4-$ inch siphon line configuration. The leak occurrence is also confirmed by the closeness of the 11:1 gas mixture concentrations to the siphon crest average accumulated gas concentrations [Phifer, 1999b]. Confirmation that atmospheric air was in the siphon crest gas-phase sample is provided by the substantial difference between the sample and duplicate measurements, which were taken in succession. The duplicate appears to contain less atmospheric air than the sample as evidenced by its decrease in measured nitrogen and oxygen and its increase in measured hydrogen over that of the sample (see Appendix D-1). Although a leak of atmospheric air into the siphon line or into the associated priming line occurred during sampling of the siphon line crest, it is not likely that atmospheric leakage played a significant role in shutting down the siphon line for the following reasons, which are detailed in sections 4.2.2 and 4.2.3:

- The gas accumulation rates are controlled by de-gassing rather than by atmospheric leakage.

- The variations in run duration between the 2-inch continuous and 2- to 1-1/4-inch siphon lines are due to the difference in the gas storage volumes of their crests.

After installation of the 2- to 1-1/4 inch siphon line configuration was complete, no leak testing of the line was conducted. Subsequently, during the initial attempt to prime the 2- to $1-1 / 4-$ inch siphon line configuration, major leaks prevented priming and were detected audibly in the HDPE joints of the siphon line. The HDPE joints were welded together in the field utilizing HPDE weld rods. This method of field welding was somewhat difficult and produced brittle joints. The leaks were repaired by HDPE welding and no subsequent leak testing of the line was conducted. Subsequent to that, a prime was pulled on the siphon line and a smaller leak was detected audibly in the saddle fitting to the priming line. Additional silicone caulk was applied to repair this fitting. At this point, no additional leaks into the siphon line or priming line could be detected audibly and testing of the 2- to 1-1/4-inch siphon line configuration commenced. This demonstrates that a siphon line can be primed and operation initiated with minor leaks and that vacuum leak testing must be conducted prior to operation to ensure that leaks are not present [Phifer, 1999b].

The calculated equilibrium gas-phase concentrations deviate somewhat from the previous air chamber gas concentrations (Phase II single-cell 8/24/99 sample). The nitrogen and oxygen concentrations are less and the methane and hydrogen concentrations are greater in the equilibrium gas-phase than in the previous air chamber gas. While the previous air chamber gas sample is considered fairly representative, some minimal atmospheric air contamination may have been introduced into that sample through an incomplete purge of the sample line during 
sampling. This could readily account for the deviations. The equilibrium gas-phase concentrations are considered to best represent the gas that would accumulate in an air chamber without leaks in the siphon line [Phifer, 1999b].

\subsubsection{Dissolved Gasses and Gasses Summary}

The following conclusions were made relative to particular dissolved gasses within the natural TNX groundwater environment:

- Nitrogen is essentially conservative relative to fate and transport within the subsurface at TNX.

- Aerobic microorganisms consume some oxygen within the subsurface at TNX.

- Dissolved-carbon dioxide is produced from the respiration of aerobic microorganisms and the presence of subsurface carbonates.

- Anaerobic microorganisms produce minor amounts of methane and hydrogen within the subsurface at TNX.

The following conclusions were made relative to particular dissolved gasses relative to groundwater flow and treatment through the TGSC-1:

- The dissolved-nitrogen concentration decreased due to the reduction of nitrogen to the ammonia ion by the zero-valent iron.

- The dissolved oxygen concentration decreased due to the corrosion of iron by oxygen, which results in dissolved oxygen gas depletion.

- The dissolved-carbon dioxide concentration decreased due to a shift in the dominant carbonate species from carbonic acid to bicarbonate; to precipitation of ferrous, calcium, and/or magnesium carbonates; and to the reduction of carbon dioxide to methane by the zero-valent iron.

- The dissolved-methane concentration increased due to the reduction of carbon dioxide to methane by the zero-valent iron.

- The dissolved hydrogen concentration increased due to the corrosion of iron by water and subsequent hydrogen gas generation.

- The dissolved-ethane and ethylene concentrations increased due to the reduction of TCE to ethane and ethylene by the zero-valent iron.

A discrepancy between the dissolved gas concentrations and the crest gas-phase concentrations indicate that the siphon line or the associated priming line had an atmospheric leak during sampling of the crest for the accumulated gas-phase. Although a leak of atmospheric air occurred during sampling of the siphon line crest, it is not likely that atmospheric leakage played a significant role in shutting down the siphon line relative to de-gassing. This demonstrates that a siphon line can be primed and operation initiated with minor leaks. However, atmospheric leakage will decrease the ability to operate in the MFV mode and increase air chamber recharging frequency. Therefore vacuum leak testing must be conducted prior to operation to ensure that leaks are not present. This atmospheric leak during sampling of the siphon line crest also invalidates the associated gas-phase analysis. The equilibrium gas-phase concentrations, 
calculated from Henry's law and the average dissolved gas concentrations, presented in Table 20 are considered most representative of the gas-phase produced from de-gassing of the treated TNX GeoSiphon Cell groundwater within the siphon line.

Table 20

Gas-phase Concentrations

\begin{tabular}{|c|c|c|}
\hline Gas & $\begin{array}{c}\text { Calculated } \\
\text { Equilibrium } \\
\text { Gas-phase } \\
\text { Concentrations } \\
\text { (\%/ Volume) }\end{array}$ & $\begin{array}{c}8 / 24 / 98 \\
\text { Air Chamber Gas } \\
\text { Concentrations } \\
\text { (\%/Volume) }\end{array}$ \\
\hline Nitrogen & 26.18 & 46.25 \\
\hline Oxygen & 1.72 & 4.88 \\
\hline Methane & 2.41 & 1.97 \\
\hline Hydrogen & 69.70 & 40.99 \\
\hline Total & 100.00 & 94.08 \\
\hline
\end{tabular}

${ }^{1}$ See Appendix $\mathrm{D}$ for the detailed calculation

${ }^{2}$ Phifer, et al., 1999a

The calculated concentration of gas produced from de-gassing during the Phase II MFV testing was richer in hydrogen and more depleted in oxygen than the sample taken during the Phase II single-cell testing (see Table 20). This latest gas analysis (calculated equilibrium gas-phase concentrations of Table 20) is considered to best represent the gas that would accumulate in an air chamber without leaks into the siphon line. It is recommended that the flammability issue be re-evaluated based upon the Table 20 calculated equilibrium gas-phase concentrations and mixture with air. The evaluation should be performed assuming a mixture of Table 20 concentrations with air rather than a mixture of Table 20 concentrations with stoichiometric quantities of oxygen since a mixture with stoichiometric quantities of oxygen cannot be achieved and is unrealistic [Phifer, 1999b].

\subsubsection{Toxicity}

One sample was collected on April 26, 1999, by the EMS samplers for toxicity testing. Shealy Environmental Services, Inc. conducted a Ceriodaphnia Dubia, 48-hour, static, acute toxicity test at an IWC of $33 \%$ per EPA-600/4-90-027. This toxicity test was a pass/fail evaluation based upon mortality of the organisms. The sample passed and is considered non-toxic to aquatic organisms. 


\subsection{SAMPLING AND ANALYSIS SUMMARY}

The Phase II MFV field data indicate that the cell is operating geochemically as anticipated, with only slight deviations from the values recorded during Phase I. These slight deviations may be due to the essentially start-up conditions of the Phase II MFV test runs.

Additionally, the influent and effluent TCE concentrations demonstrate that degradation sufficient to reduce the influent TCE concentrations to below $5 \mu \mathrm{g} / \mathrm{L}$ was occurring. However, the effluent TCE concentrations were somewhat greater than would have been anticipated based upon the Phase I results. The deviation between the measured TCE discharge concentrations and the anticipated TCE discharge concentrations based upon Phase I results could be the result of one or a combination of the following:

- Normal system start-up fluctuations

- Inapplicability of the Phase I correlation

- Decrease in the apparent first order rate constant due to a decrease in inlet TCE concentrations

- Iron deactivation, probably due to precipitation fouling

To evaluate the potential for iron deactivation due to precipitation fouling, which is the most problematic possible explanation for this deviation, a review of the specific capacity over time was conducted. Specific capacity is the flow rate per unit drawdown in TGSC-1 and is a measure of the head loss or ease of water flow through a combination formation and the cell (i.e., GeoNet with filter fabric, granular cast iron, and screen). The available specific capacity data is insufficient to make an absolute determination of whether precipitation fouling, as evidenced by specific capacity decreases over time, is occurring. Therefore, tracking the TCE discharge results from analyses using US EPA-certified methods over time and tracking the specific capacity at a near constant flow rate over time needs to be performed to determine if any negative trends are developing [Phifer, 1999b]. Additionally determination of the first order rate constant from sampling and analysis of the TGSC-1 sampling ports, as performed during Phase I testing [Phifer, et al., 1998], should be performed over time to assist in the evaluation of potential iron deactivation.

The dissolved gas results indicate that several naturally occurring processes within the natural TNX groundwater environment and several processes related to the use of zero-valent iron within the TNX GeoSiphon Cell are producing significant dissolved gas changes involving nitrogen, oxygen, carbon dioxide, methane, hydrogen, ethane, and ethylene.

Additionally, a discrepancy between the dissolved gas concentrations and the crest gas-phase concentrations indicated that atmospheric air leaked into the siphon line or into the associated priming line during sampling of the crest for its accumulated gas-phase. Although a leak of atmospheric air occurred during sampling of the siphon line crest, it is not likely that atmospheric leakage played a significant role in shutting down the siphon line relative to de-gassing. However, this demonstrates that a siphon line can be primed and operation initiated with minor leaks and that vacuum leak testing must be conducted prior to operation to ensure that leaks are 
not present.

The calculated concentration of gas produced from de-gassing during the Phase II MFV testing was richer in hydrogen and more depleted in oxygen than the previous 8/24/99 sample (see Table 20). These calculated concentrations are considered more representative of gas produced from de-gassing, without atmospheric leakage into the siphon line, than any of the gas-phase sampling and analysis for the reasons previously stated. It is recommended that the flammability issue be re-evaluated based upon the Table 20 calculated equilibrium gas-phase concentrations and mixture with air. The evaluation should be performed assuming a mixture of Table 20 concentrations with air rather than a mixture of Table 20 concentrations with stoichiometric quantities of oxygen since a mixture with stoichiometric quantities of oxygen cannot be achieved and is unrealistic [Phifer, 1999b].

Based upon toxicity testing, the treated groundwater is considered non-toxic to aquatic organisms. 
Left Blank Intentionally 


\subsection{EXISTING CELL OPERATION OPTIONS}

\subsection{MFV OPERATION MODE SUMMARY}

The MFV mode of operation does not appear to be a viable option for maintaining continuous, consistent, full siphon flow between the existing two TNX GeoSiphon Cells (TGSC-1 and TGSC-2) and the X-08 outfall ditch for the following reasons:

- The head available to drive the system will vary substantially with variations in the groundwater elevations and Savannah River stage. No matter what size siphon line is utilized to produce a particular flow velocity at average head conditions, available head conditions will at times be below that required to produce the MFV. At such times the system will go down and will require re-priming when available head conditions improve to the point that the necessary velocity can be produced. The timing and duration associated with any such down time cannot be predicted.

- The current TNX GeoSiphon Cells were constructed in a Pre-Siphon Treatment Cell Configuration (see Figure 18), with granular cast iron utilized as the treatment media. In this configuration, the groundwater is treated producing increased dissolved hydrogen in the water, prior to transportation within the siphon line. As discussed in Section 5.2, the zero-valent iron treatment of groundwater caused the dissolved hydrogen concentration to increase approximately six orders of magnitude above background groundwater concentrations (see Table 15). This increase in dissolved hydrogen produced an increased de-gassing volume of a hydrogen-rich gas within the siphon line over what would occur with the transport of untreated groundwater. This resulted in the requirement for a MFV greater than would be required for the transport of untreated groundwater.

The MFV mode of siphon line operation, however, is a viable option for consideration when a sufficient minimum head exists to produce the required MFV. MFV use is also enhanced when groundwater with typical dissolved gasses (i.e., nitrogen, oxygen, carbon dioxide, etc.) at typical concentrations rather than hydrogen-rich water (see Table 15) is transported by the siphon. However, even where the MFV mode is viable, its use will often result in slightly lower flow rates than other modes of operation such as an air chamber. This occurs since smaller diameter siphon lines may be required to obtain the velocities necessary for the MFV mode to transport bubbles out the end of the siphon. Additionally, the MFV mode is not as robust in terms of continuous, consistent, full siphon flow when compared to other modes of operation such as an air chamber. It relies upon a minimum velocity to sweep bubbles below a certain size out the end of the siphon. Reductions in flow rates, which result in decreased velocities and/or system upsets, that cause larger size bubbles than can be transported, will cause the system to shut down. Such occurrences are difficult if not impossible to predict. The MFV mode should become more robust as the minimum available head to drive the system increases. 


\subsection{EXISTING CELL OPERATION OPTIONS OVERVIEW}

Operational modes other than MFV, such as an air chamber, do not depend upon maintenance of a minimum velocity or a maximum bubble size. These other modes of operation are more robust and more predictable as to the duration between required operational attention. Additionally the use of an air chamber with manual recharging and the use of CNP have both been demonstrated to be effective in maintaining continuous, consistent, full siphon flow of the TNX GeoSiphon Cell siphon lines.

The siphon lines for the existing TNX GeoSiphon Cells can be operated in the following modes:

- Air chamber mode of operation

- CNP mode of operation

- Continuous water-driven eductor, venturi, or pump mode of operation

\subsubsection{Air Chamber Operational Mode}

An air chamber is essentially a high point accumulation chamber for gasses that de-gas from the water within the siphon line. The air chamber allows accumulation of the gas within the chamber itself while preventing accumulation within the siphon line. Air chambers are located above the siphon line at the line high point (crest) and are connected to the siphon line. The air chamber is initially filled with water during priming of the siphon line. As the system operates, de-gassing occurs and the buoyancy of the gas and/or the flow of water transport the gas to the air chamber. The gas accumulates and displaces the water in the air chamber. The gas in the air chamber must be evacuated and replaced with water on a periodic basis to maintain the siphon line free of accumulated gas. The air chamber can be sized to minimize the frequency of refilling [Gibson, 1961; Mathur, 1990; Phifer, et al., 1998; Phifer, et al., 1999a].

The air chamber mode of operating a siphon line has been demonstrated to work with the existing TNX GeoSiphon Cells (see Phifer, et al., 1999a and section 4.2.3 of this report). As noted above, the only operational requirement associated with the use of air chambers is that the air chamber be recharged with water on a periodic basis. Recharging TNX GeoSiphon Cells siphon line air chamber(s) can be accomplished by one of the following methods:

- Manually or automatically, utilizing a nitrogen-driven vacuum pump

- Manually or automatically from an artesian well

- Manually from another water source such as the creek or water truck

- Automatically utilizing a solar-powered vacuum pump

\subsubsection{Air Chamber Recharge Utilizing a Nitrogen-Driven Vacuum Pump}

Figure 19 provides a diagram of the setup to recharge the air chamber manually or automatically utilizing a nitrogen-driven vacuum pump such as the Vaccon vacuum pump, which is used to prime the system (see section 4.2). A manual air chamber is recharged (see Figure 19, Detail A) by manually operating the regulator on the nitrogen cylinder so that nitrogen at the appropriate 
pressure can flow through the vacuum pump. The valve between the air chamber and vacuum pump (isolation valve) is then opened manually without shutting the siphon line down. The gas within the air chamber evacuates to the atmosphere within the nitrogen exhaust from the vacuum pump, and water is pulled up from the siphon line to fill the air chamber. Once the air chamber is full of water, the isolation valve is then manually closed and the nitrogen flow to the vacuum pump is shut off. The manual method of recharging an air chamber with a nitrogen-driven vacuum pump has been demonstrated to work [Phifer, et al., 1999a] although use of the pump requires periodic replacement of the nitrogen cylinders.

The air chamber can be recharged automatically (see Figure 19, Detail B) utilizing low- and high-level water sensors/indicators to initiate operation of solenoid valves at the nitrogen cylinder regulator and between the air chamber and vacuum pump (isolation solenoid valve) in the proper sequence. When the water level in the air chamber drops to the level of the low-level water sensor, the regulator solenoid valve opens, followed by opening of the isolation solenoid valve. The siphon line is not shut down. The gas within the air chamber is then evacuated to the atmosphere within the nitrogen exhaust from the vacuum pump, and water is pulled up from the siphon line to fill the air chamber. When the water level in the air chamber rises to the level of the high-level water sensor, the isolation solenoid valve closes, followed by closing the regulator solenoid valve. The low- and high-level water sensors/indicators and solenoid valves can be powered by batteries and solar panels. Automatic air chamber recharging, utilizing a nitrogendriven vacuum pump, requires periodic replacement of the nitrogen cylinders.

\subsubsection{Air Chamber Recharge from an Artesian Well}

Figures 20 and 21 provide diagrams of the setup to recharge the air chamber manually or automatically utilizing an artesian well. Table 21 provides information on the P-26 well cluster, which is located approximately 2,000-ft upgradient from TGSC-1. The high ground around TGSC-1 is at a maximum $100 \mathrm{ft}-\mathrm{msl}$. Based upon the P-26 water level elevation data of Table 21 and the TGSC-1 ground elevation of $100 \mathrm{ft}-\mathrm{msl}$, artesian water at pressures up to $42 \mathrm{psig}$ (96 $\mathrm{ft}$ ) is potentially available at the ground surface at the TGSC-1 location. Artesian water from this location is sufficient to fill an air chamber.

The air chamber can be recharged by manual operation of the valves (see Figure 21, Detail A). The valve between the siphon line and the air chamber (isolation valve) is manually closed without shutting the siphon line down. The gas release valve on top of the air chamber is then manually opened, followed by manually opening the water supply valve from the artesian well. Water from the artesian well fills the air chamber and forces the gas within the air chamber out the gas release valve into the atmosphere. Once the air chamber is full of water, the water supply valve and the gas release valve manually closes, and the isolation valve manually opens.

The air chamber can be recharged automatically (see Figure 21, Detail B) utilizing low- and high-level water sensors/indicators to initiate operation of isolation, gas release, and water supply solenoid valves in the proper sequence. When the water level in the air chamber drops to the level of the low-level water sensor, the isolation solenoid valve closes, and the gas release and water supply solenoid valves open in sequence without shutting the siphon line down. Water 
from the artesian well fills the air chamber and forces the gas within the air chamber out of the gas release valve into the atmosphere. When the water level in the air chamber rises to the level of the high-level water sensor, the water supply and gas release solenoid valves close in sequence, and the isolation solenoid valve opens. The low- and high-level sensors/indicators and solenoid valves are powered by batteries and solar panels.

Table 21

TNX Artesian Conditions - P26 Well Cluster

\begin{tabular}{|c|c|c|c|c|c|}
\hline Well & Coordinates & $\begin{array}{l}\text { Screen Zone } \\
(\mathrm{ft}-\mathrm{msl})\end{array}$ & $\begin{array}{c}\text { TOC or TOS } \\
\text { (ft-msl) }\end{array}$ & $\begin{array}{c}\text { Depth to } \\
\text { Water below } \\
\text { TOC or TOS } \\
1\end{array}$ & $\begin{array}{c}\text { Water } \\
\text { Elevation } \\
\text { (ft-msl) }\end{array}$ \\
\hline P-26TA & $\begin{array}{l}\text { N71958.6 } \\
\text { E18051.5 }\end{array}$ & $\begin{array}{l}-537.8 \text { to } \\
-527.2\end{array}$ & 154.6 & $\begin{array}{c}+8 \mathrm{psig} / \\
18.5 \mathrm{ft}\end{array}$ & 173.1 \\
\hline P-26TB & $\begin{array}{l}\text { N71973.4 } \\
\text { E18057.0 }\end{array}$ & $\begin{array}{c}-383.1 \text { to } \\
-372.3\end{array}$ & 154.5 & $\begin{array}{c}+18 \mathrm{psig} / \\
41.6 \mathrm{ft}\end{array}$ & 196.1 \\
\hline P-26TC & $\begin{array}{l}\text { N71987.7 } \\
\text { E18062.5 }\end{array}$ & $\begin{array}{l}-233.1 \text { to } \\
-222.5\end{array}$ & 154.1 & Not available & - \\
\hline P-26TD & $\begin{array}{l}\text { N72001.7 } \\
\text { E18067.5 }\end{array}$ & $\begin{array}{c}-97.8 \text { to } \\
-87.8\end{array}$ & 154.2 & $-1.98 \mathrm{ft}$ & 152.22 \\
\hline $\mathrm{P}-26 \mathrm{~A}$ & $\begin{array}{l}\text { N72010.4 } \\
\text { E18055.9 }\end{array}$ & 22 to 32 & 154.5 & $33.66 \mathrm{ft}$ & 120.84 \\
\hline $\mathrm{P}-26 \mathrm{~B}$ & $\begin{array}{l}\text { N71996.2 } \\
\text { E18050.9 }\end{array}$ & 71.9 to 82.4 & 154.5 & $43.43 \mathrm{ft}$ & 111.07 \\
\hline P-26D & $\begin{array}{l}\text { N71969.3 } \\
\text { E18041.6 }\end{array}$ & $\begin{array}{c}101.8 \text { to } \\
121.9\end{array}$ & 154.5 & $35.28 \mathrm{ft}$ & 119.22 \\
\hline
\end{tabular}

${ }^{1} 12 / 18 / 92$ depth to water measurements

\subsubsection{Air Chamber Recharge from another Water Source}

The air chamber can be manual recharged from a water source such as the creek or water truck in a manner similar to manual artesian well recharging.

\subsubsection{Air Chamber Recharge Utilizing a Solar-Powered Vacuum Pump}

Figure 22 provides a diagram of potential setups to recharge the air chamber automatically utilizing a solar-powered vacuum pump as suggested by ETFG. The air chamber could be automatically recharged continuously if the vacuum pump can handle water flow or intermittently if it can not. Continuous air chamber recharging could potentially be accomplished as shown in Figure 22, Detail A. As the system operates, de-gassing occurs and the buoyancy of the gas and/or the flow of water transport the gas to the small air chamber, 
located above the siphon line at the line high point (crest). This prevents gas accumulation within the siphon line. The low capacity, solar-powered vacuum pump then continuously purges the gas and/or water from the small air chamber.

The air chamber could be automatically recharged on an intermittent basis as shown in Figure 22, Detail B. Low- and high-level water sensors/indicators within the air chamber initiate operation of the vacuum pump and open the solenoid valve between the air chamber and vacuum pump (isolation solenoid valve) in the proper sequence. When the water level in the air chamber drops to the level of the low-level water sensor, the vacuum pump turns on and the isolation solenoid valve opens, without shutting the siphon line down. The vacuum pump forces the gas in the air chamber to evacuate to the atmosphere and water is pulled up from the siphon line to fill the air chamber. When the water level in the air chamber rises to the level of the high-level water sensor, the isolation solenoid valve closes, the vacuum pump turns off. The low- and high-level sensors/indicators, solenoid valve, and vacuum pump can be powered by batteries and solar panels.

\subsubsection{Continuous Nitrogen-Purge Operational Mode}

The CNP mode of operation (see Figure 23) involves the use of a very small air chamber, which is continuously purged utilizing a low capacity, nitrogen-driven, vacuum pump. The low capacity, nitrogen-driven, vacuum pump is similar to, but of a lower capacity than, the Vaccon vacuum pump utilized to prime the system (see section 4.2). As the system operates, de-gassing occurs, and the buoyancy of the gas and/or the flow of water transport the gas to the small air chamber, located above the siphon line at the line high point (crest), preventing gas accumulation within the siphon line. The low capacity, nitrogen-driven, vacuum pump then continuously purges the gas from the small air chamber.

Operating a siphon line using this mode has been demonstrated to work with the existing TNX GeoSiphon Cells (see section 4.2.3 of this report). The primary operational requirement is periodic replacement of the nitrogen cylinders utilized to drive the low capacity, nitrogen-driven vacuum pump. The vacuum pump can be sized to maximize the duration between required nitrogen cylinder replacement.

\subsubsection{Continuous Water-Driven Eductor, Venturi, Or Pump Operational Mode}

The continuous water-driven eductor, venturi, or pump mode of operation (see Figure 24) involves the use of a very small air chamber, which is continuously purged utilizing a low capacity, water-driven eductor, venturi, or pump. ETFG has suggested use of a venturi or pump. As the system operates, de-gassing occurs, and the buoyancy of the gas and/or the flow of water transport the gas to the small air chamber, located above the siphon line at the line high point (crest). This prevents gas accumulation within the siphon line. The low capacity eductor, venturi, or pump then continuously purges the gas from the small air chamber. The source of water to drive the eductor comes from an artesian well, the discharge from the siphon line, the X08 outfall, the Savannah River, or some other source of water from TNX (Figure 24 shows the system with an artesian well water source). As stated above, artesian water at pressures up to 42 
psig (96 ft) is potentially available at the ground surface at the TGSC-1 location. Although artesian conditions do exist in the TNX floodplain, the exact depth and pressure of available artesian water to drive an eductor, venturi, or pump would need to be verified. Verification is necessary since a minimum 30-psig source of water is typically required to drive the eductor. However, since the volume of gas to be removed is small, an eductor could possibly operate from a water source with less than 30 psig.

The CNP mode of operating a siphon line, which is similar to the continuous water-driven eductor mode, has been demonstrated to work with the existing TNX GeoSiphon Cells (see section 4.2 .3 of this report). However, the operational requirements associated with the continuous, water-driven eductor mode of operation should be less than that associated with the CNP mode as long as a reliable source of water is obtained to drive the system and a suitable eductor can be obtained.

\subsubsection{Other Operational Modes}

Other potential modes of operating the siphon lines for the existing TNX GeoSiphon Cells include the following discussed in a Creativity Committee Meeting Minutes (i.e., brain storming session, see Appendix E):

- Sol-gel metal hydride use for the adsorption of hydrogen from the gas within an air chamber

- Chemical addition to eliminate some or all gasses (i.e., hydrogen, nitrogen, oxygen, and methane)

- Diffusion membrane technology use for the diffusion of the gasses out of the siphon line

- Venturi at the end of the siphon line operated off the flow of the siphon line to remove gas from the air chamber utilizing the vacuum produced from the venturi

While these modes of operating the siphon lines may have some long-term potential, they all require significant additional research to address their viability. Additionally they may not be applicable to the existing two cells.

Other potential modes of operating the existing TNX Cells without the use of a siphon include the following:

- Pumping the system

- Gravity drainage

These operational modes produce a treatment system, which is not a GeoSiphon Cell. Pumping renders the cells part of a treat and pump system. Gravity drainage use renders the cells part of a GeoFlow system. 


\subsubsection{De-gassing Reduction Enhancements}

The following enhancements can be made to any of the above siphon operational modes to reduce siphon line de-gassing:

- The siphon line can be installed underground to maintain a more constant lower temperature, thereby minimizing the impact of high atmospheric temperatures causing the de-gassing rate to increase.

- The height of the siphon line above the groundwater table elevation can be minimized, thereby minimizing the vacuum within the siphon line and the subsequent de-gassing due to the vacuum.

- The length of the siphon line can be minimized, thereby minimizing the time that the treated water is within the siphon line and the time over which de-gassing can occur.

\subsection{EXISTING CELL OPERATION OPTIONS SUMMARY AND RECOMMENDATIONS}

In summary, the use of the MFV mode of operation does not appear to be a viable option for maintaining continuous, consistent, full siphon flow between the existing two TNX GeoSiphon Cells (TGSC-1 and TGSC-2) and the X-08 outfall ditch. Several other siphon operational modes exist, that will maintain continuous, consistent, full siphon flow. Based upon the treatability studies to date and the desire by ERD for as passive a system as possible for operation of the existing TNX GeoSiphon Cells, the following are recommended:

- Laboratory-scale testing to evaluate the ability of a solar-powered, vacuum pump to passively recharge an air chamber should be performed, as suggested by ETFG.

- If the solar-powered, vacuum pump laboratory system proves successful, installation of the system in the field should be performed for a long-term field-scale demonstration. This would demonstrate long-term, continuous, consistent operation utilizing the solarpowered, vacuum pump and allow the evaluation of the siphon flows under various conditions of head. Additionally it would allow the evaluation of possible iron precipitation fouling and iron deactivation through the determination of the specific capacity, the TCE discharge concentration, and the TCE first order rate constant.

- Concurrent with the solar-powered, vacuum pump laboratory scale testing, design, installation, and long-term testing of a manually recharged air chamber GeoSiphon system for operation of the existing two cells should be performed. The manual air chamber system should be designed to be compatible with the solar-powered vacuum pump option. This would allow installation of the field solar-powered, vacuum pump system onto the then existing manual air chamber system, once the solar-powered, vacuum pump system was laboratory proven, assuming it is proven. Long-term operation of the manual air chamber system would demonstrate long-term continuous, consistent operation and allow the evaluation of the siphon flows, gas generation rates, and gas composition under various conditions of head, temperature, etc. Additionally it 
would allow the evaluation of possible iron precipitation fouling and iron deactivation through the determination of the specific capacity, the TCE discharge concentration, and the TCE first order rate constant. The air chamber(s) should be sized to be compatible with the solar-powered vacuum pump option and to optimize the duration between recharging events to minimize operating and maintenance costs associated with recharging and capital costs associated with air chamber installation. The air chamber(s) can be recharged manually utilizing either a nitrogen-driven vacuum pump or another water source such as the creek or a water truck. Such a concurrent approach would expedite long-term field'testing of the TNX GeoSiphon system, while allowing evaluation of two operational modes. 


\subsection{ALTERNATE GEOSIPHON CELL CONFIGURATION}

The current TNX GeoSiphon Cells were constructed in a Pre-Siphon Treatment Cell Configuration (see Figure 18) with granular cast iron utilized as the treatment media. The TNX GeoSiphon Cells are essentially large diameter wells, which contain granular cast iron (the treatment media) in place of gravel pack. Contaminated groundwater flows radially inward from the aquifer, through the granular cast iron, and into the screen. This flow is passively induced by use of a siphon from the cell to the X- 08 outfall ditch. The flow is induced by the natural hydraulic head difference between the cell and the X-08 outfall ditch. The granular cast iron reduces the TCE to ethane, ethene, and chloride ions. The treated water is subsequently discharged through the X-19 outfall to the X-08 outfall ditch, which flows into the Savannah River. [Phifer, et al., 1999a]

In this configuration with iron as the treatment media two items of significance occur which impact the operation and potential longevity of the cells:

- The outer iron surface area furthest from the cell's screen first comes into contact with the contaminated groundwater. It is this portion of the iron, which is most likely to incur the highest level of precipitation (see section 5.2.2).

- Due to the corrosion of iron by water, the treated groundwater has a significant increase in the level of dissolved-hydrogen (see section 5.2.3) prior to transport through the siphon line.

The longevity of the cells is potentially impacted by precipitation within the iron, which might lead to iron deactivation and porosity loss. Iron deactivation results in decreased treatment rates and porosity loss results in increased head loss and subsequent reductions in flow rates. While the iron might be reactivated and porosity restored through acid washing, the iron in the cells can only be indirectly accessed through the cell's screen, it cannot be directly accessed. Again, the outer iron surface area furthest from the cell's screen is the iron most likely to incur the highest level of precipitation. Therefore, it is most likely to incur iron deactivation and porosity loss (as measured through TCE discharge results and specific capacity measurements, see section 5.2.2). It is also this portion of the iron in this configuration from which it would be difficult, but not impossible, to remove the precipitates due to its remoteness from the screen.

Siphon transport of this iron treated groundwater, with its significant dissolved-hydrogen content, results in a significant increase in siphon line de-gassing volume over the siphon transport of untreated groundwater. This increased hydrogen rich de-gassing results in the following:

- The requirement to utilize higher velocities than required for typical groundwater to implement the MFV mode of operation.

- An increased frequency between air chamber recharging events or a larger air chamber is required, and an increase in the hydrogen content of the gas collected in the air 
chamber occurs over what would occur with the transport of untreated groundwater.

An alternate GeoSiphon configuration could overcome these items: a GeoSiphon Cell PostSiphon Treatment Cell Configuration (see Figure 25).

"The GeoSiphon Cell Post-Siphon Treatment Cell Configuration is a recovery well or trench connected by siphon to a downgradient, surface-accessible, rechargeable, permeable treatment media cell. The siphon flow is induced by the natural hydraulic head difference between the recovery well or trench and the cell (available head). The passively induced flow draws contaminated groundwater through the recovery well or trench, then through the siphon line, and finally to the treatment cell where the permeable treatment media treats the groundwater. The treated water is subsequently discharged to the ground surface or surface water." [Phifer, et al., 1999b]

In this configuration, the iron is surface-accessible and rechargeable, and removal of precipitates can be accomplished more easily. Additionally, in this configuration only the typical groundwater dissolved-gasses (i.e., nitrogen, oxygen, carbon dioxide, etc.) would be present to de-gas within the siphon line. The de-gassing volume produced from these gasses is less than that of hydrogen at similar dissolved phase concentrations due primarily to the low atomic weight of hydrogen relative to the others. Even if an air chamber was utilized to increase reliability and flow rates, the gas collected would not contain significant levels of hydrogen and the air chamber would have to be recharged less infrequently when compared to the current configuration. Additional advantages of this configuration include the averaging of contaminant levels prior to treatment, due to extraction from the entire contaminate width and thickness and mixing within the extraction well or trench prior to siphon transport and treatment. This results in the more efficient use of the iron (i.e., less iron would be required and the cell could be significantly smaller to treat the same volume of contaminated groundwater). [Phifer, et al., 1999b; Phifer, 1999b] The primary concern associated with implementation of a post-siphon treatment cell configuration at TNX would be wetlands issues associated with the location of the treatment cell.

The D-Area Permeable Reactive Barrier / GeoSiphon Treatment System has been built with both pre- and post-siphon treatment. Unlike the iron treatment, the D-Area pre-siphon treatment consists of a limestone trench, which should minimally impact the groundwater's dissolvedgasses. Therefore, this system's siphon line should behave similar to the siphon line associated with a post-siphon treatment cell configuration. Integrity testing of the siphon began on May 26, 1999, and siphon flow continued continuously, except on weekends, through June 18, 1999, without the use of an air chamber (i.e. it operated in the MFV mode). Testing of the siphon with an air chamber began on June 21,1999 , and siphon flow continued continuously through July 30 , 1999. Operation of the D-Area siphon line should be similar to operation of a siphon line associated with a post-siphon treatment cell configuration with iron as the treatment media [Phifer, 1999e]. 
In summary, the pre-siphon treatment cell configuration of the current TNX GeoSiphon Cells with zero valent iron as the treatment media results in a system in which:

- Precipitation, which may lead to iron deactivation and porosity loss, predominantly occurs within that portion of the iron, which is difficult to access for removal of the precipitates,

- Zero valent iron treatment prior to siphoning results in the transport of water with a significant dissolved-hydrogen content, which at equivalent dissolved concentrations produces a larger de-gas volume than the typical groundwater dissolved-gasses. As a result increased velocities are required to implement the MFV mode of operation and increased quantities of hydrogen rich gas is collected in the air chamber mode of operation.

These do not occur with the post-siphon treatment GeoSiphon Cell configuration. In this configuration, the iron is accessible from the surface and rechargeable. Therefore, removal of precipitates can be accomplished much more easily. Additionally, the zero valent iron treatment, which results in the formation of the hydrogen, occurs at the end of the siphon and would not impact siphon operation. Therefore, it is recommended that a post-siphon treatment cell configuration with iron as the treatment media be considered for any expansion of the TNX GeoSiphon Cell system. 


\section{Left Blank Intentionally}




\subsection{CONCLUSIONS AND RECOMMENDATIONS}

Phase II MFV testing was conducted utilizing TGSC-1. During this testing, the use of MFV to maintain passive, continuous, consistent, full siphon flow from TGSC-1 to the X-08 outfall ditch discharge point, without the need to manually recharge an air chamber, was evaluated under the existing conditions at TNX. MFV testing of both continuous 2-inch and 2-inch upward leg to 1$1 / 4$-inch crest and downward leg siphon line configurations were conducted.

Initial flow rates during testing were consistent with the calculated flow rates based upon the available head difference. However, a gas phase, which was not transported out of the end of the siphon, began accumulating in the crest a short period of time after priming was completed. The gas-phase accumulation resulted in flow reductions, which continued to decline until the line was re-primed or flow ceased. In these tests the siphon line was not able to maintain continuous, consistent, full siphon flow, indicating that a higher velocity than achieved was required to operate in the MFV mode.

Based upon this testing the use of the MFV mode of operation does not appear to be a viable option for maintaining continuous, consistent, full siphon flow between the existing two TNX GeoSiphon Cells (TGSC-1 and TGSC-2) and the X-08 outfall ditch for the following reasons:

- The head available to drive the system will vary substantially with variations in the groundwater elevations and Savannah River stage, resulting in head conditions which at times will be below that required to produce the minimum flushing velocity. At such times the system will go down and will require re-priming when available head conditions improve to the point that the necessary velocity can be produced. The timing and duration associated with any such down time cannot be predicted.

- The current TNX GeoSiphon Cells with granular cast iron produce increased dissolved hydrogen in the water. This increase in dissolved hydrogen produced an increased degassing volume of a hydrogen-rich gas within the siphon line over what would occur with the transport of untreated groundwater. This resulted in the requirement for a MFV greater than would be required for the transport of untreated groundwater.

Due to the inability to maintain continuous, consistent, full siphon flow utilizing MFV, a CNP test was conducted. During the CNP test, gas was removed from the crest of the 2 to $1-1 / 4$-inch siphon line continuously using the existing priming system. CNP is analogous to use of an air chamber, and both modes of operation are capable of maintaining continuous, consistent, full siphon flow.

The following are other observations associated with these MFV tests:

- Lower average temperatures resulted in a greater dissolved-gas capacity of the treated water and less de-gassing in the siphon line. The estimated gas accumulation rates 
determined during the 2 to $1-1 / 4$-inch MFV siphon line testing ranged from 0.026 gallons/hour at an atmospheric temperature of $11.7^{\circ} \mathrm{C}$ to 0.063 gallons/hour at an atmospheric temperature of $30.5^{\circ} \mathrm{C}$ at the flow rates tested.

- A siphon line can be primed and operation initiated with minor atmospheric leaks. Additionally, if the gas is removed from the line (i.e., an air chamber or CNP is used to remove gas), the siphon line can be operated with minor atmospheric leaks. Therefore, siphon priming, operation initiation, and operation alone do not assure that atmospheric leaks are not present.

- The Eh and $\mathrm{pH}$ data collected conform to the typical Eh decrease (oxidation/reduction potential) and $\mathrm{pH}$ increase associated with the zero-valent, iron-enhanced, abiotic degradation of CVOCs, indicating that the cell is operating as anticipated.

- Based upon analysis utilizing US EPA-certified methods, reduction of the influent TCE concentrations to below $5 \mu \mathrm{g} / \mathrm{L}$ occurred.

- Specific capacity measurements at near constant flow rates over time and TCE discharge results from analyses using US EPA-certified methods over time can be utilized to evaluate the potential for iron deactivation and porosity loss due to precipitation fouling.

- The available specific capacity data is insufficient to make an absolute determination of whether or not significant precipitation fouling is occurring.

- The determination of TCE first order rate constants can be utilized to evaluate the potential for iron deactivation.

- The dissolved gas results indicate that several naturally occurring processes within the natural TNX groundwater environment and several processes related to the use of zerovalent iron within the TNX GeoSiphon Cell are producing significant dissolved gas changes involving nitrogen, oxygen, carbon dioxide, methane, hydrogen, ethane, and ethylene.

- Based upon calculations the Phase II MFV gas produced from de-gassing was richer in hydrogen and more depleted in oxygen than indicated by previous sampling and analysis.

- Toxicity testing indicates that the treated groundwater is non-toxic to aquatic organisms.

As demonstrated previously with an air chamber [Phifer, et al., 1999a] and herein with the CNP, siphon operational modes other than MFV exist. These can maintain continuous, consistent, full siphon flow between the two existing TNX GeoSiphon Cells (TGSC-1 and TGSC-2) and the X08 outfall ditch. Based upon the treatability studies to date and the desire by ERD for as passive 
a system as possible for operation of the existing TNX GeoSiphon Cells, the following are recommended:

- Laboratory-scale testing to evaluate the ability of a solar-powered, vacuum pump to passively recharge an air chamber should be performed, as suggested by ETFG.

- If the solar-powered, vacuum pump laboratory system proves successful, installation of the system in the field should be performed for a long-term field-scale demonstration. This would demonstrate long-term, continuous, consistent operation utilizing the solarpowered, vacuum pump and allow the evaluation of the siphon flows under various conditions of head. Additionally it would allow the evaluation of possible iron precipitation fouling and iron deactivation through the determination of the specific capacity, the TCE discharge concentration, and the TCE first order rate constant.

- Concurrent with the solar-powered, vacuum pump laboratory scale testing, design, installation, and long-term testing of a manually recharged air chamber GeoSiphon system for operation of the existing two cells should be performed. The manual air chamber system should be designed to be compatible with the solar-powered vacuum pump option. This would allow installation of the field solar-powered, vacuum pump system onto the then existing manual air chamber system, once the solar-powered, vacuum pump system was laboratory proven, assuming it is proven. Long-term operation of the manual air chamber system would demonstrate long-term continuous, consistent operation and allow the evaluation of the siphon flows, gas generation rates, and gas composition under various conditions of head, temperature, etc. Additionally it would allow the evaluation of possible iron precipitation fouling and iron deactivation through the determination of the specific capacity, the TCE discharge concentration, and the TCE first order rate constant. Such a concurrent approach would expedite longterm field testing of the TNX GeoSiphon system, while allowing evaluation of two operational modes.

The following are other recommendations associated with operation of the existing TNX GeoSiphon Cell(s), some of which were also made by the Creativity Committee (see Appendix E):

- Vacuum leak testing prior to siphon line operation should be conducted to ensure that leaks are not present.

- Tracking TCE discharge results from analyses using US EPA-certified methods over time and tracking specific capacity at a near constant flow rate over time needs to be performed to determine if any negative trends are developing relative to the potential for iron deactivation and porosity loss due to precipitation fouling.

- TCE first order rate constants should be determined for TGSC-1 to assist in the evaluation of the potential for iron deactivation.

- A camera survey should be performed of the cell's screen to determine if precipitates are forming on the screen [Phifer, 1999b].

- The flammability issue should be re-evaluated based upon the Table 20 calculated 
equilibrium gas-phase concentrations and mixture with air. This latest gas analysis (calculated equilibrium gas-phase concentrations of Table 20) is considered to best represent the gas that would accumulate in an air chamber without leaks into the siphon line as discussed in section 5.2.3.2. The evaluation should be performed assuming a mixture of Table 20 concentrations with air rather than a mixture of Table 20 concentrations with stoichiometric quantities of oxygen since a mixture with stoichiometric quantities of oxygen cannot be achieved and is unrealistic [Phifer, 1999b].

- The siphon line can be installed underground or insulated to maintain a more constant lower temperature, thereby minimizing the impact of high atmospheric temperatures causing the de-gassing rate to increase.

- The height of the siphon line above the groundwater table elevation can be minimized, thereby minimizing the vacuum within the siphon line and the subsequent de-gassing due to the vacuum.

- The length of the siphon line can be minimized, thereby minimizing the time that the treated water is within the siphon line and the time over which de-gassing can occur.

It is further recommended that a post-siphon treatment cell configuration with iron as the treatment media be considered for any expansion of the TNX GeoSiphon Cell system (see Figure 25). 


\section{REFERENCES}

ETI, 1996. Feasibility Study Report, CVOC Iron Degradation Study Using Groundwater from the TNX Area, Savannah River Technology Center, Aiken, South Carolina, ETI Reference: 31054.10, EnviroMetal Technologies, Inc., Waterloo, Ontario, Canada.

Gibson, A. H., 1961. Hydraulics and Its Applications, $3^{\text {rd }}$ ed., London: Constable \& Company LTD.

Graedel, T. E., 1978. Chemical Compounds in the Atmosphere, New York: Academic Press.

Lide, D. R., editor, 1998-1999. CRC Handbook of Chemistry and Physics, $79^{\text {th }}$ ed., New York: CRC Press.

Lintern, J. A., "Modification to SCDHEC Construction Permit \#18,234-IW; TNX GeoSiphon Cell Phase II Siphon Line Reconfiguration, " ESH-CGP-98-0361, October 30, 1998.

Lintern, J. A., "SCDHEC Partial Permit to Operate; Modification to SCDHEC Construction Permit \#18,234-IW; TNX GeoSiphon Cell Phase II Siphon Line Reconfiguration," ESH-CGP-99-0095, March 24, 1999.

Loitz, D. B., de Steiguer, A. L., and Broz, W. R., 1990. "Siphon Quenches," Civil Engineering, Vol. 60 , No. 8, August, 1990, pp. 44-46.

Manahan, S. E., 1991. Environmental Chemistry, $5^{\text {th }}$ ed., Chelsea, Michigan: Lewis Publishers, Inc.

Mathur, J., 1990. "Draw some Help from Hydraulic Grade Lines," Chemical Engineering Progress, October, 1990, pp. 50-54.

Mirtov, B. A., 1964. Gaseous Composition of the Atmosphere and Its Analysis, Jerusalem: Israel Program for Scientific Translations.

Nichols, R. L., Dixon, K. L., and Noonkester, J. V. Well Installation and Sampling Report for Monitoring Wells TCM6, TCM7 and TNX 28D-40D and GeoSiphon Cell TGSC-2 (U). WSRCTR-99-00226, Savannah River Site, Aiken, SC 29808 (1999).

Phifer, M. A., "Permeable Wall Laboratory Study Final Report," SRT-ESS-96-365, August 6, 1996.

Phifer, M. A., Sappington, F. C., and Denham, M. E. TNX GeoSiphon Cell (TGSC-1) Phase I Deployment / Demonstration Final Report. WSRC-TR-98-00032, Savannah River Site, Aiken, SC 29808 (1998).

Phifer, M. A., Sappington, F. C., Nichols, R. L., and Dixon, K. L. TNX GeoSiphon Cell (TGSC1) Phase II Single Cell Deployment / Demonstration Final Report. WSRC-TR-98-00432, 
Savannah River Site, Aiken, SC 29808 (1999a).

Phifer, M. A., "TNX GeoSiphon Cell Phase II Minimum Flushing Velocity Calculations," Calculation Number GCD-6, SRT-ESS-99-120, January 22, 1999a.

Phifer, M. A. and Nichols, R. L. Task Technical and Quality Assurance Plan-TNX GeoSiphon Cell Phase II Minimum Flushing Velocity Test. WSRC-TR-99-00039, Savannah River Site, Aiken, SC 29808 (1999).

Phifer, M. A., Sappington, F. C., Nichols, R. L., Ellis, W. N., and Cardoso-Neto, J. E., 1999. "GeoSiphon/GeoFlow Treatment Systems," Tucson, Arizona: Waste Management 99 Symposia, February 28 to March 4, 1999b.

Phifer, M. A., "TNX GeoSiphon Cell Phase II Minimum Flushing Velocity Preliminary Data Evaluation, " SRT-ESS-99-282, June 7, 1999b.

Roine, A., 1997. HSC Chemistry, Version 3.0, Finland: Outokumpu Research. 


\section{FIGURES}




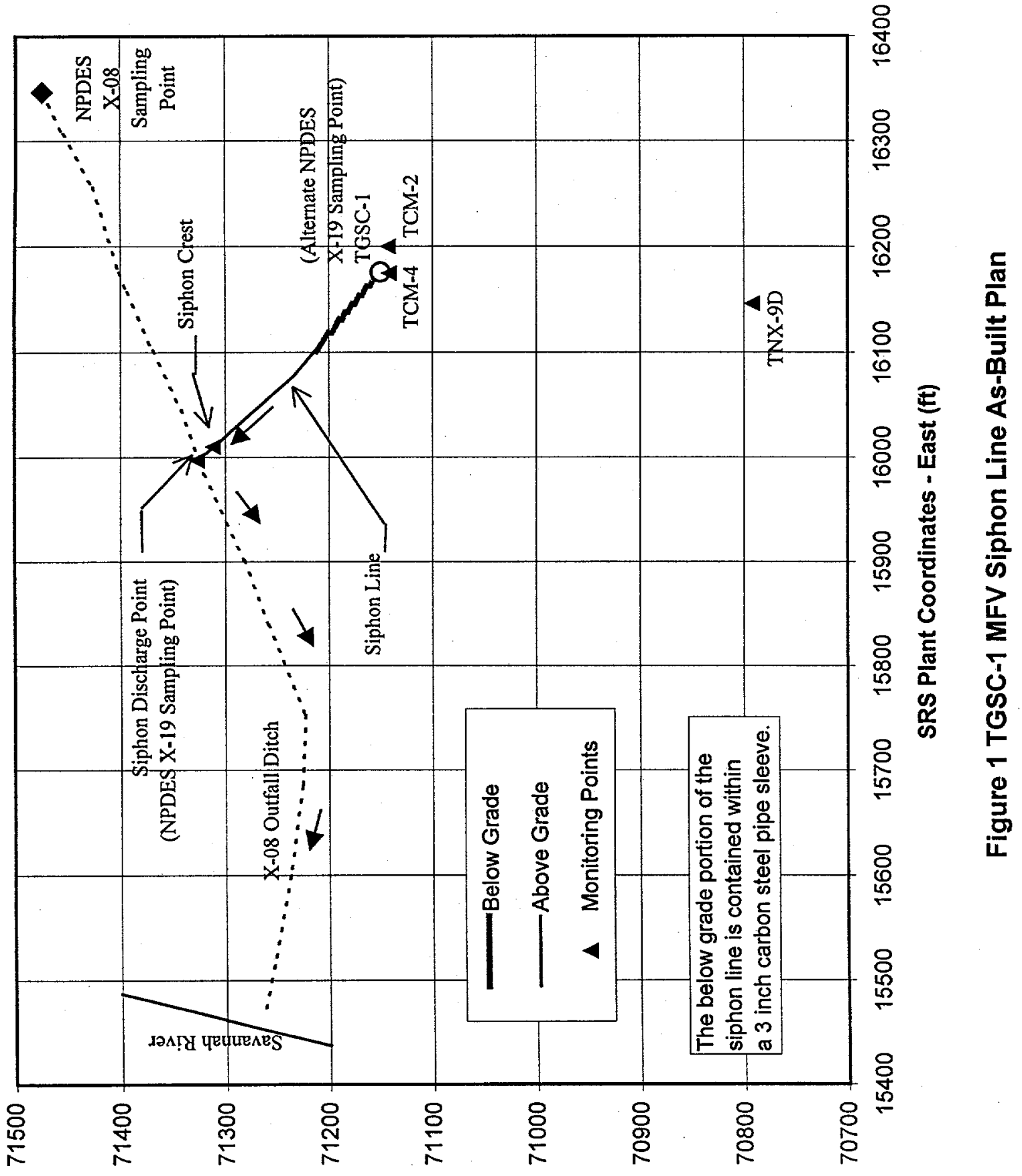

(น) 4น०N - sofeu!psooj ఫueld sys 


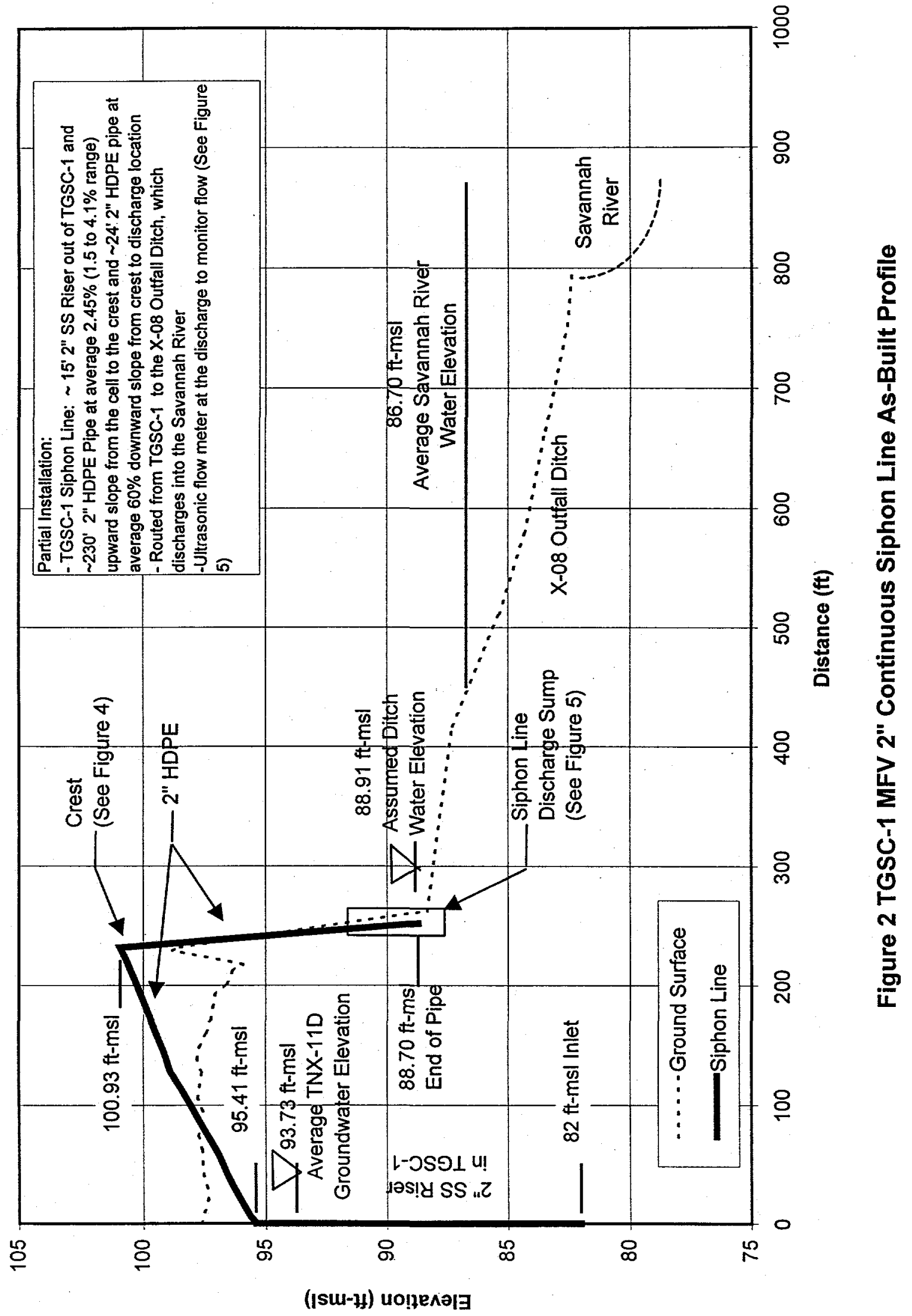




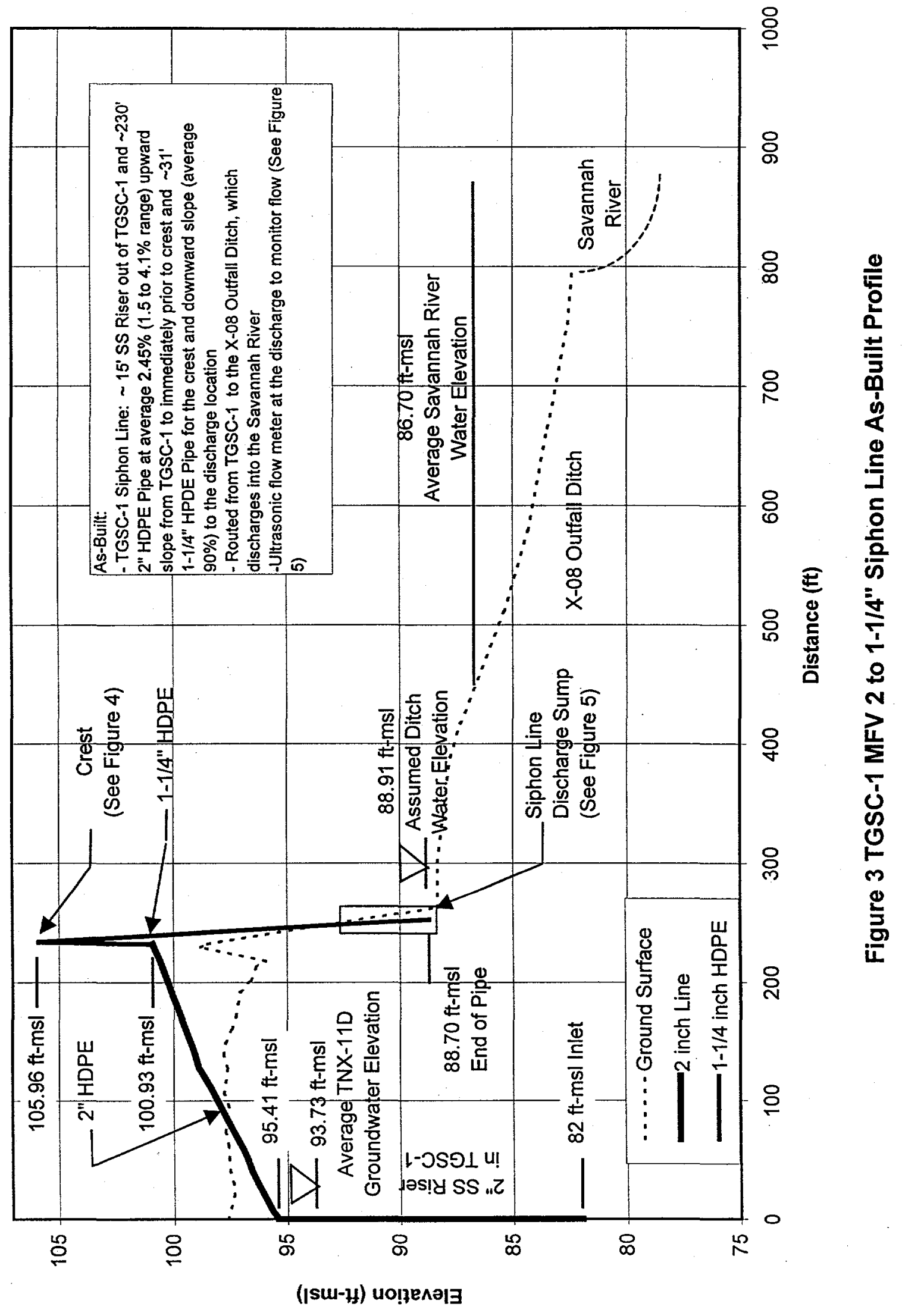




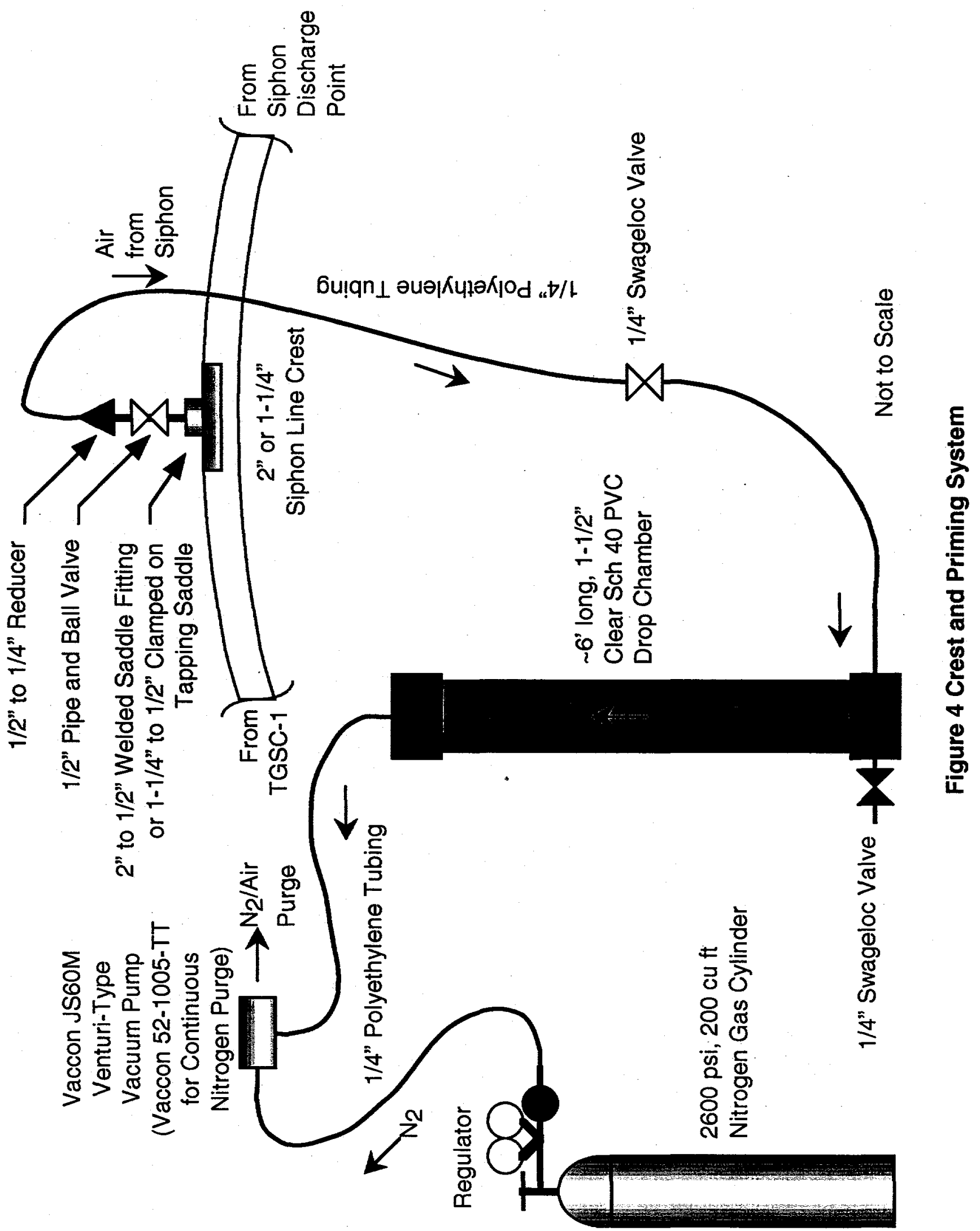




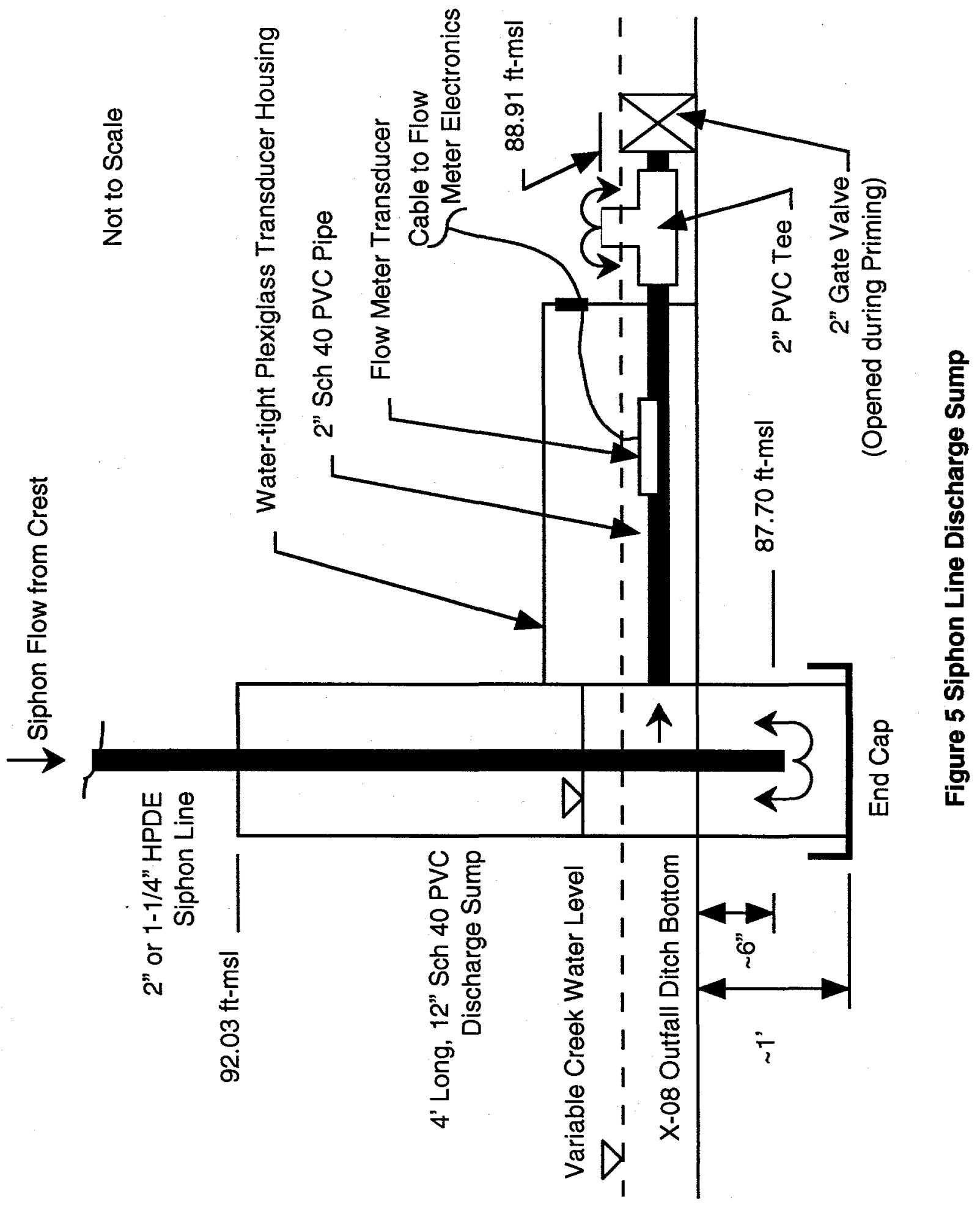


(udb) 라버 M이거

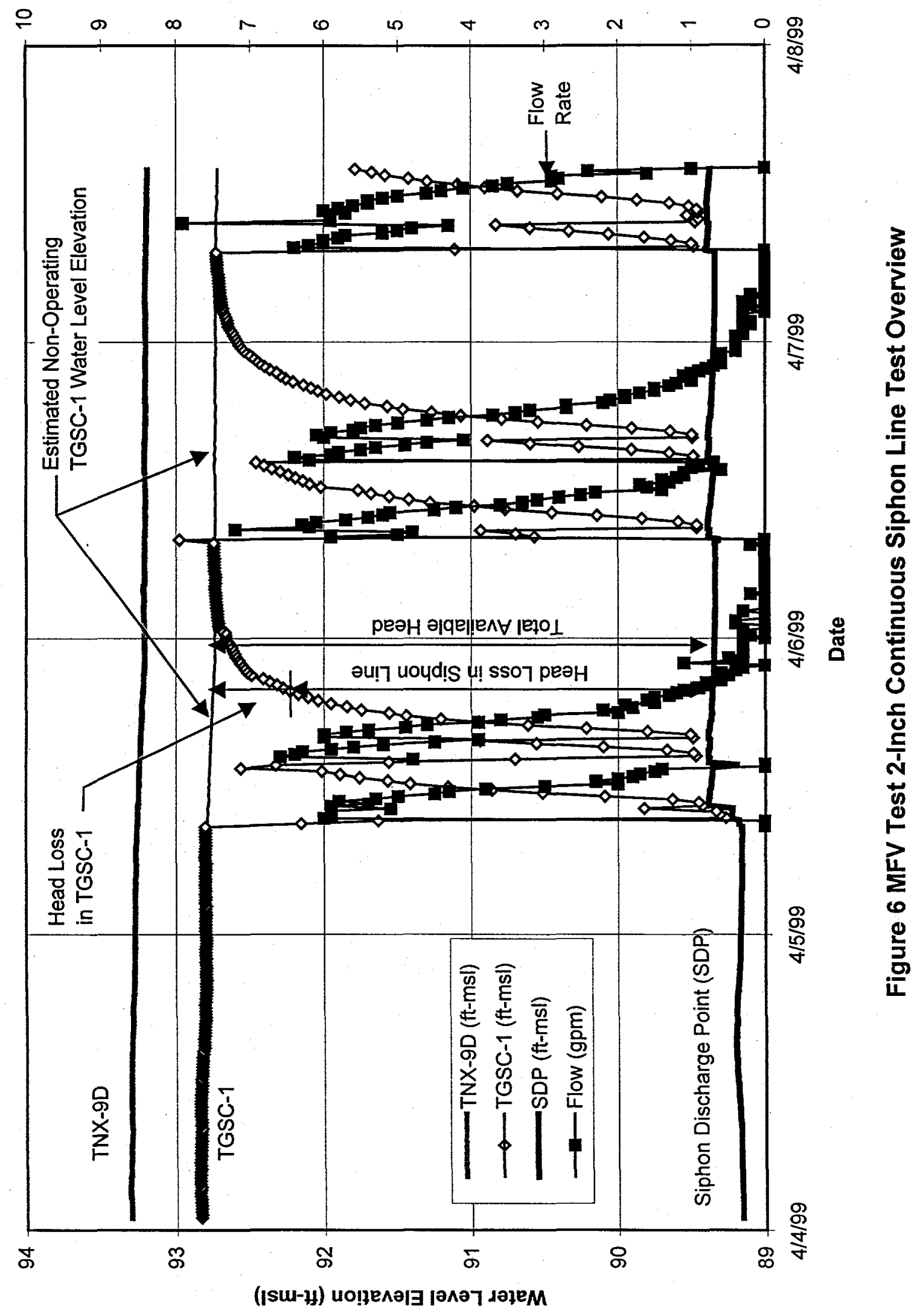




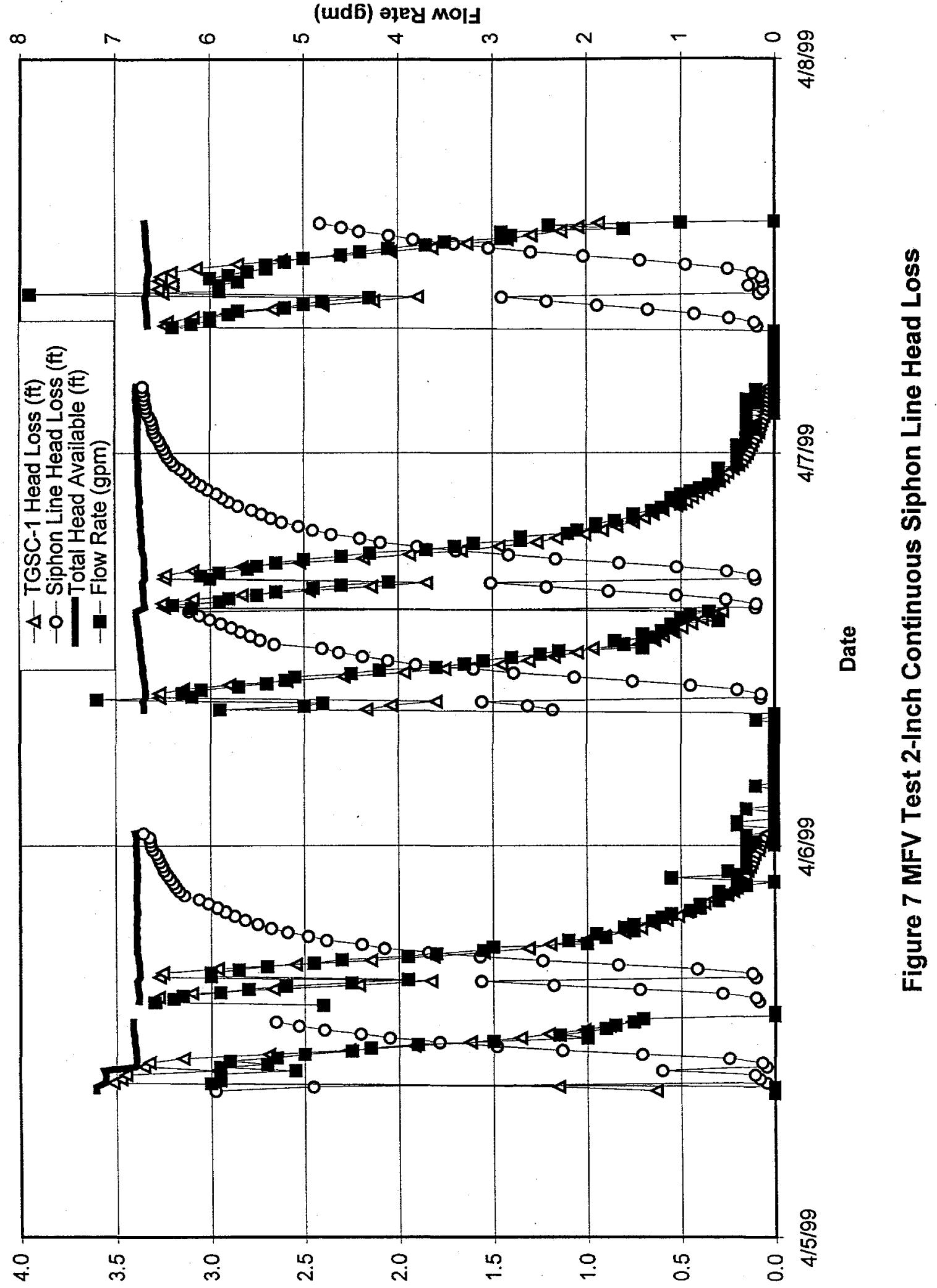

(y) ssoา pеән do реән 


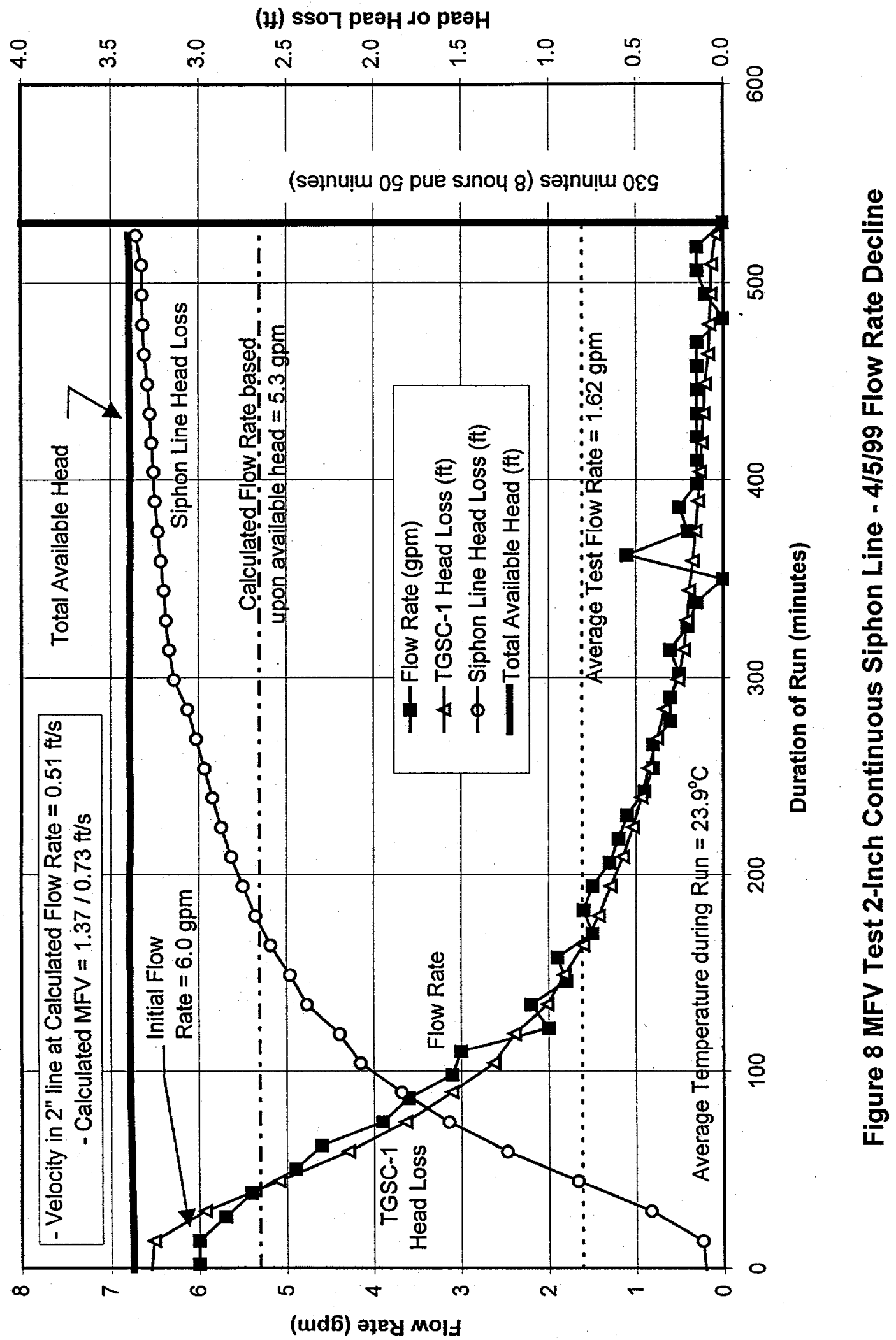




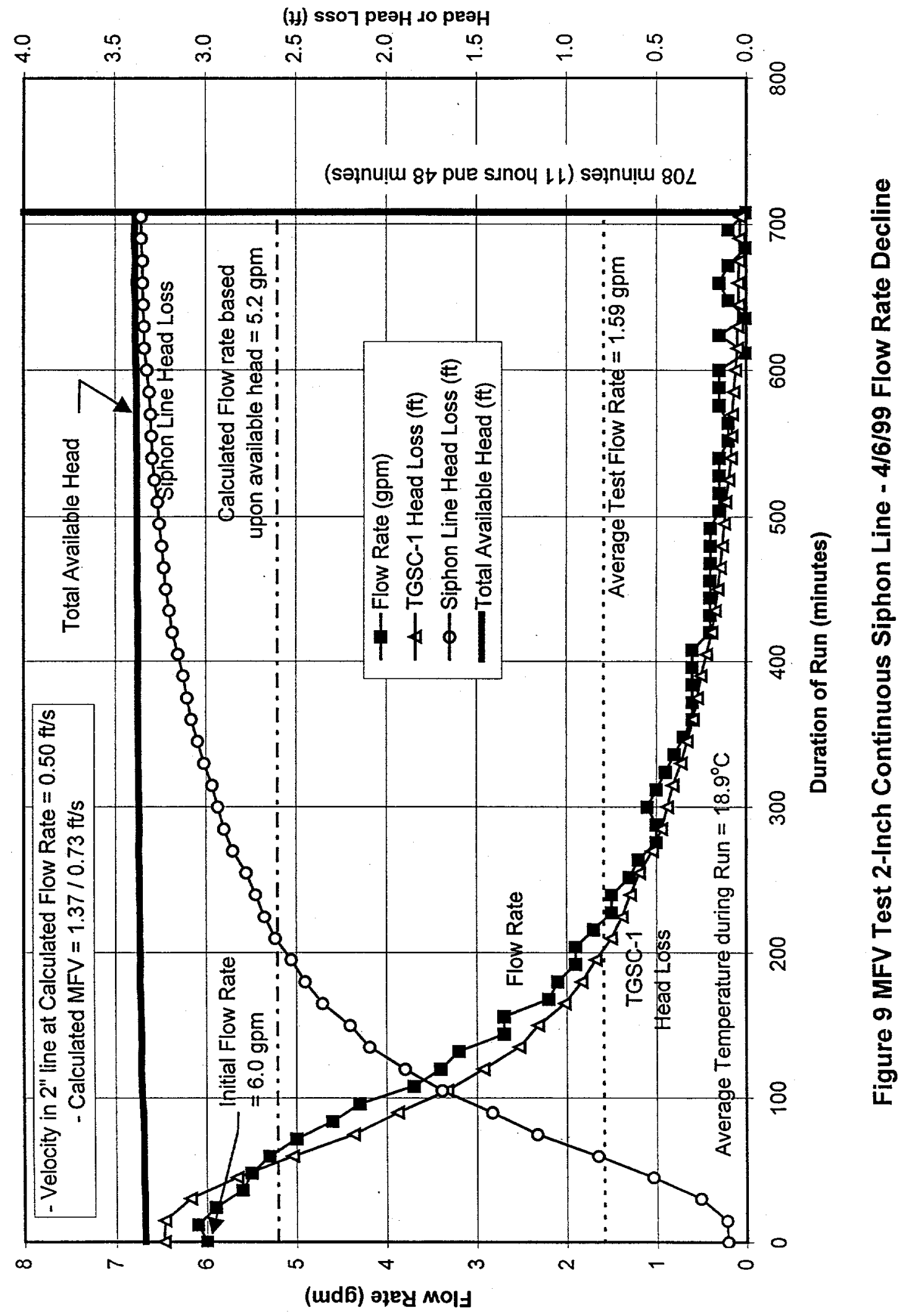




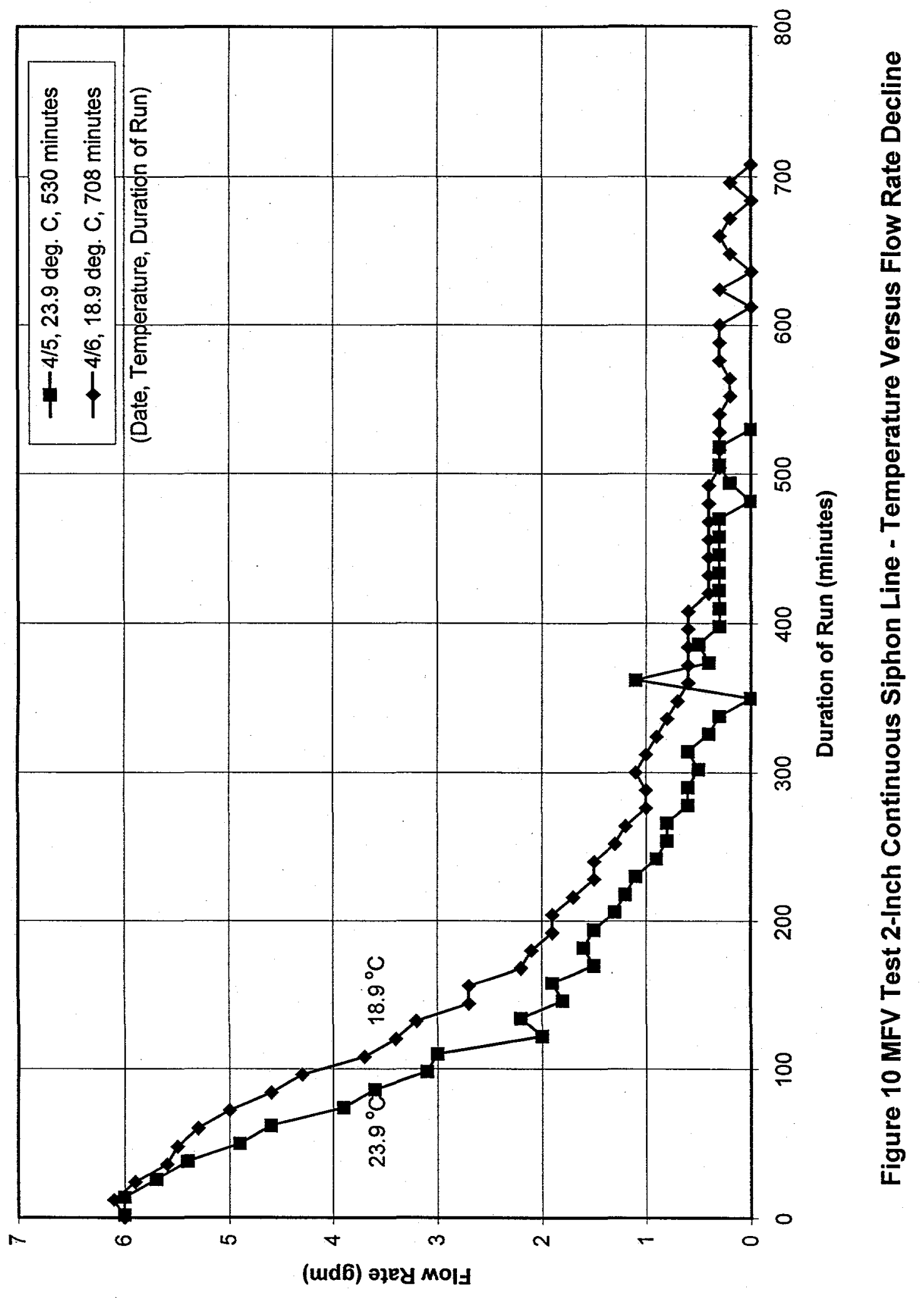


(udb) ә타 M이

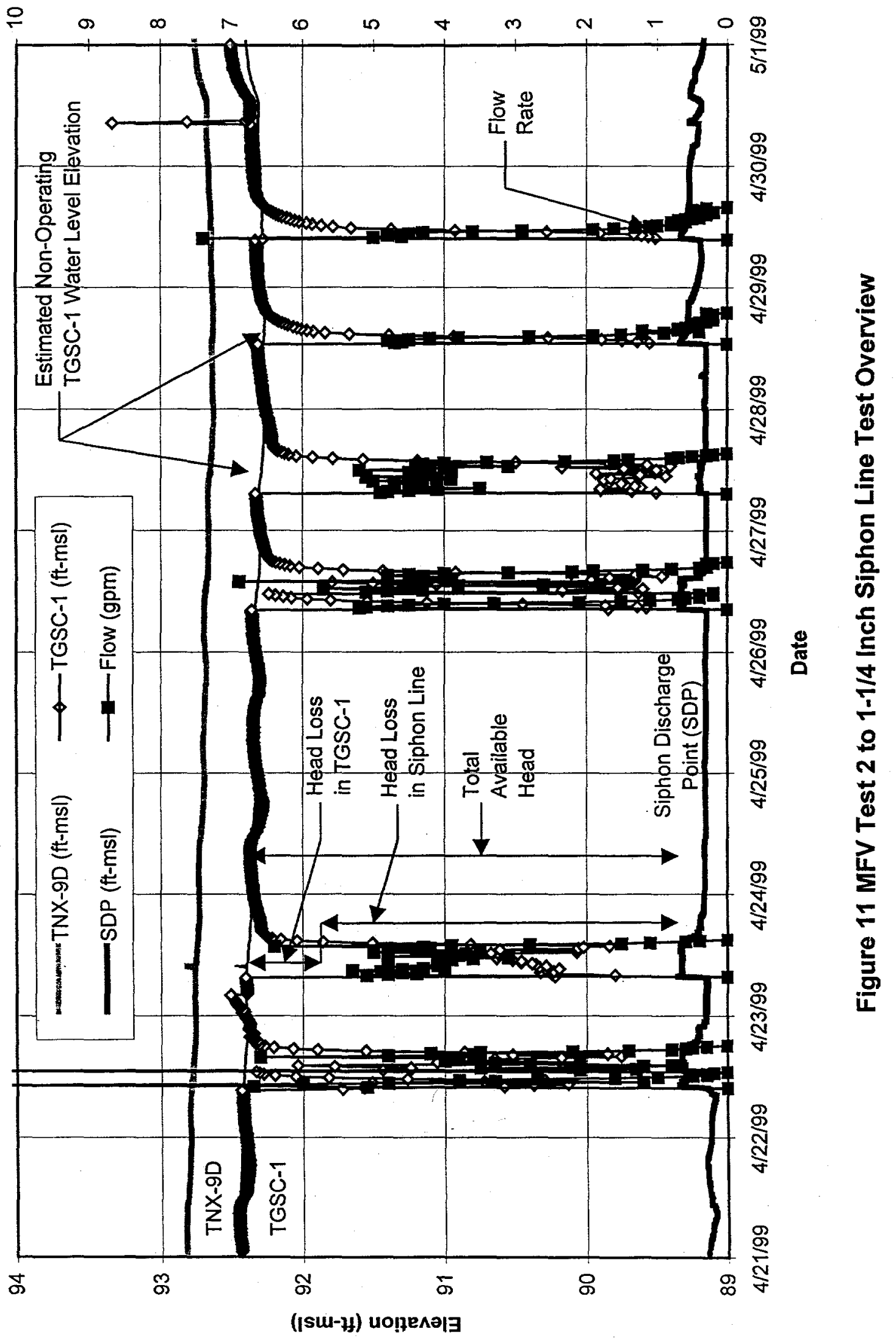




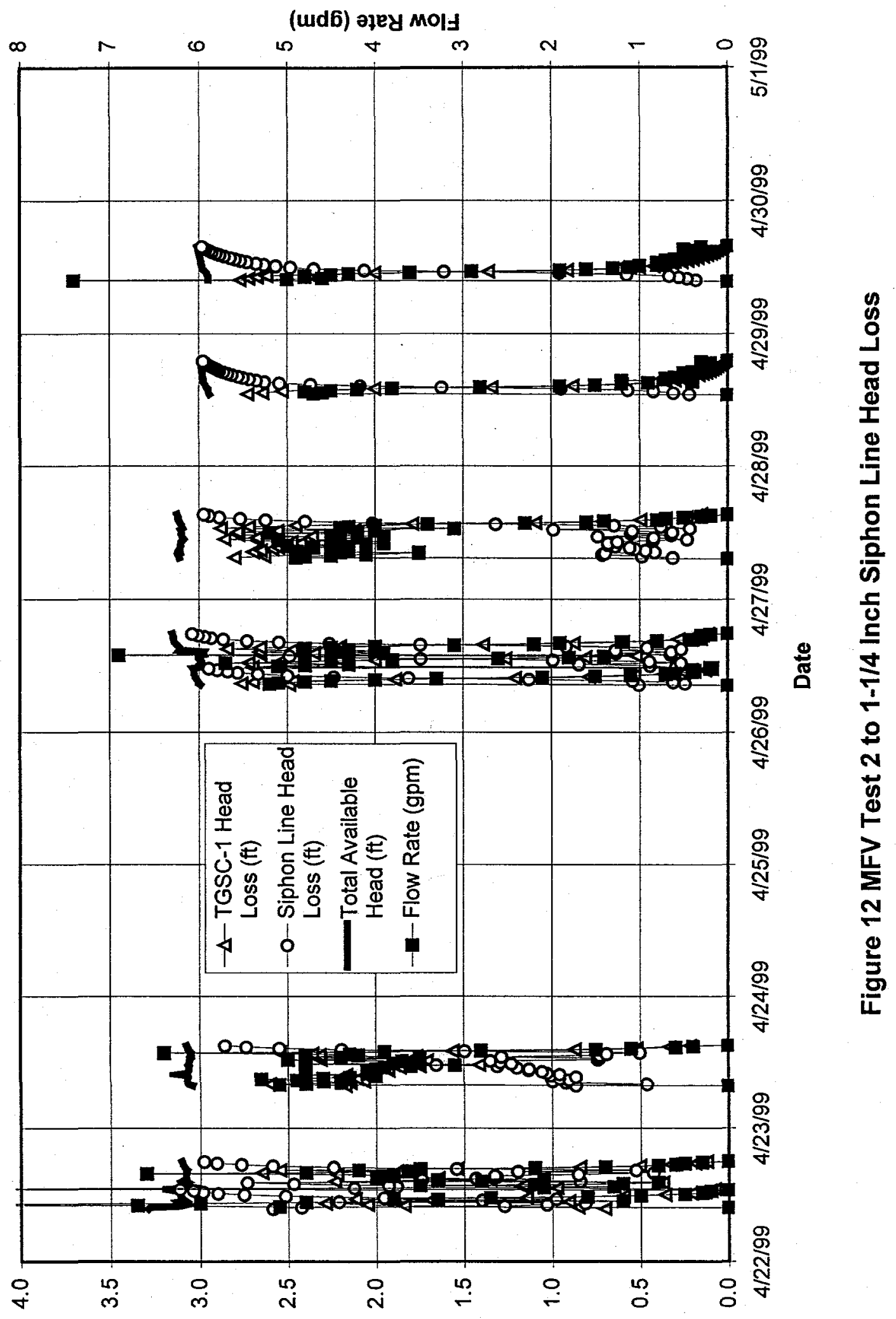

(H) sso 7 реән до реән 


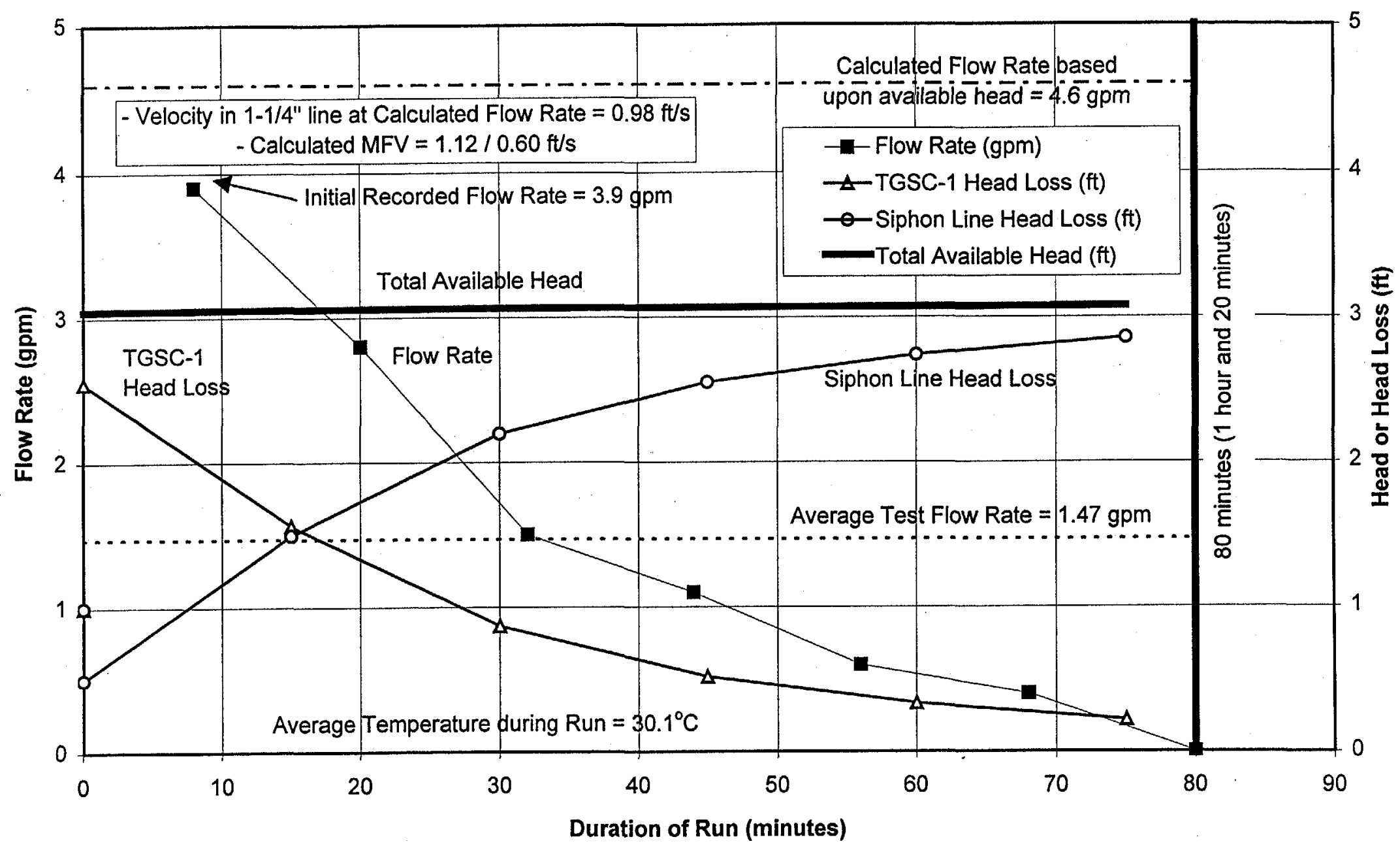

Figure 13 MFV Test 2 to 1-1/4 Inch Siphon Line - 4/23/99 Flow Rate Decline 


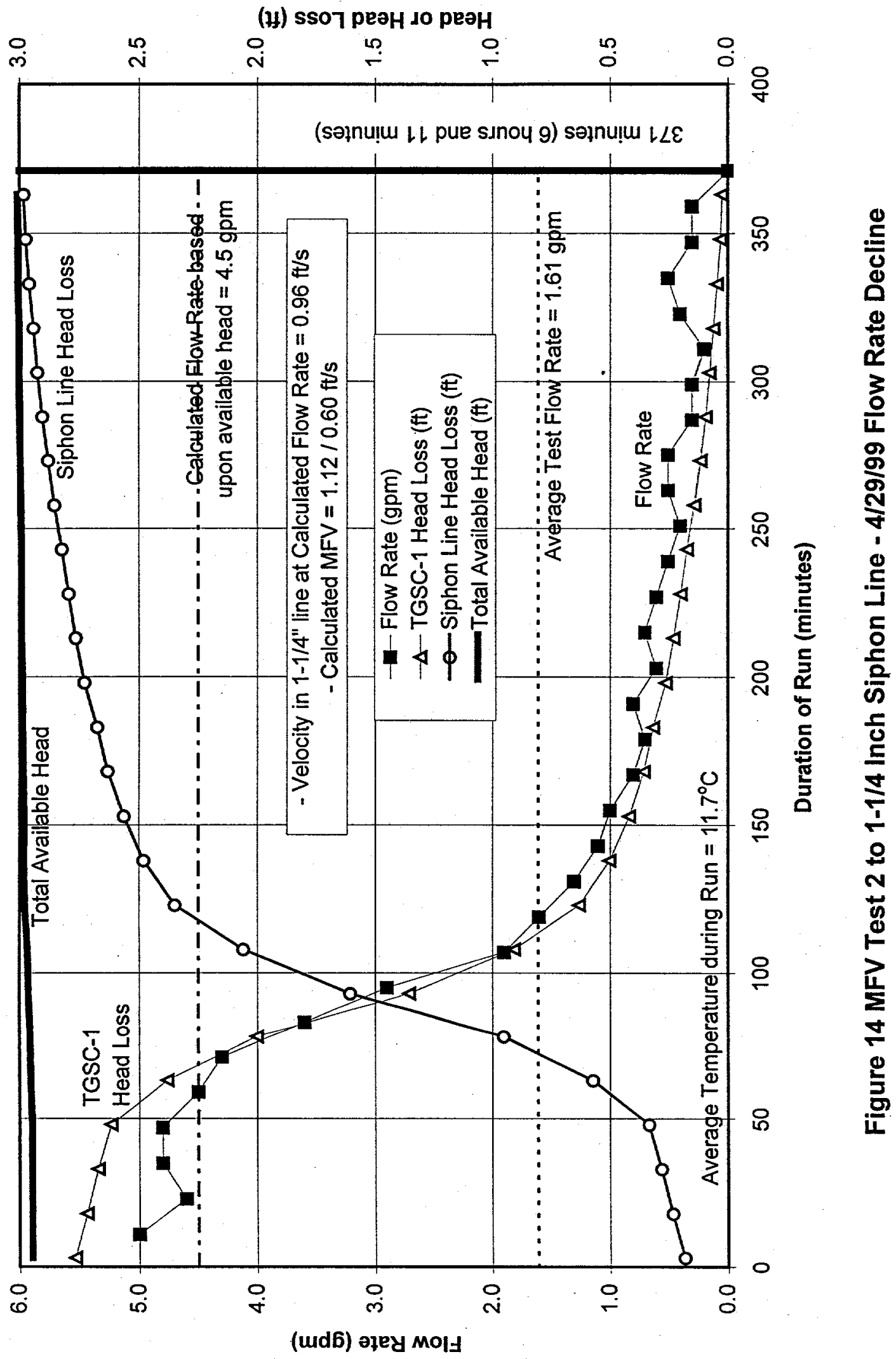




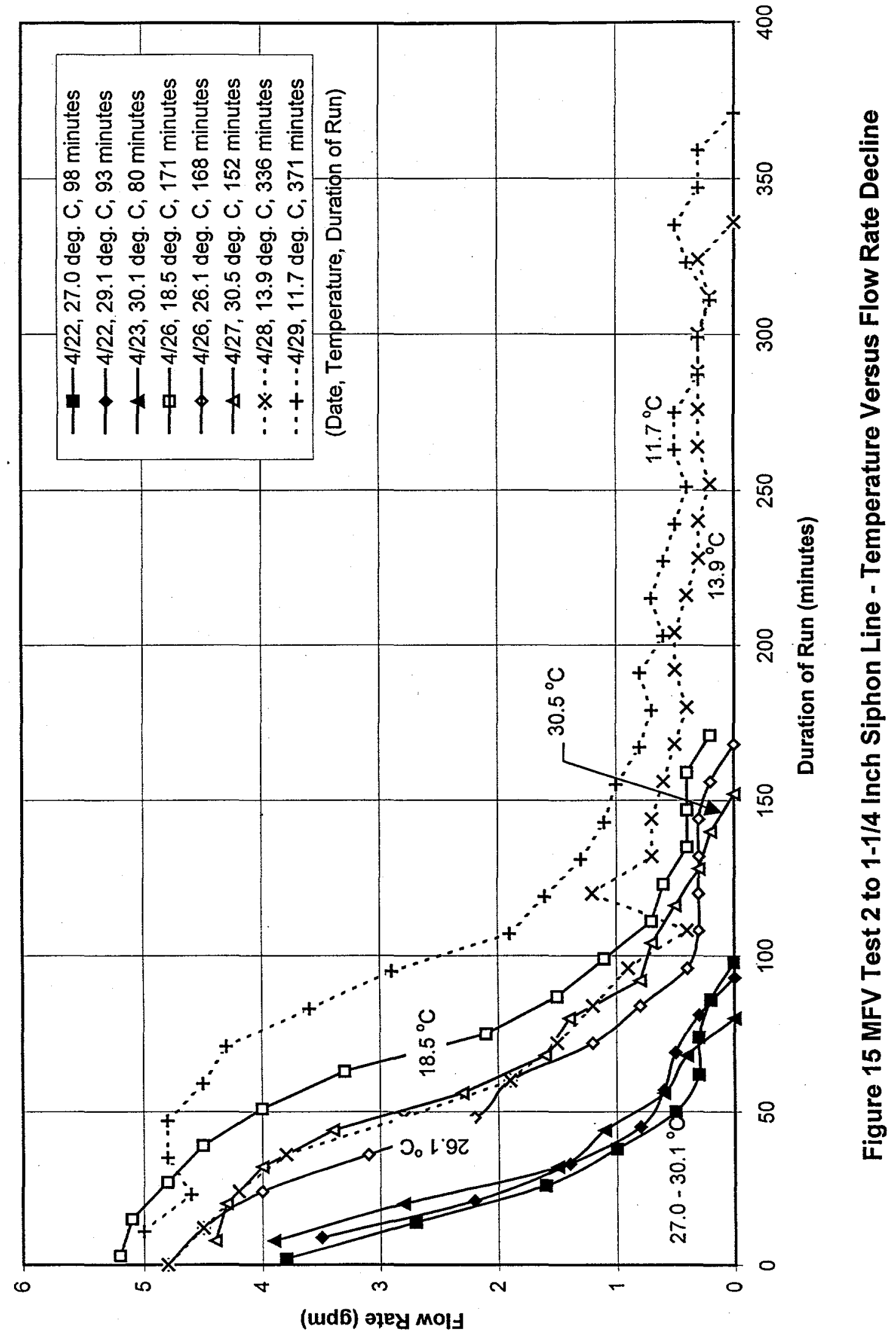




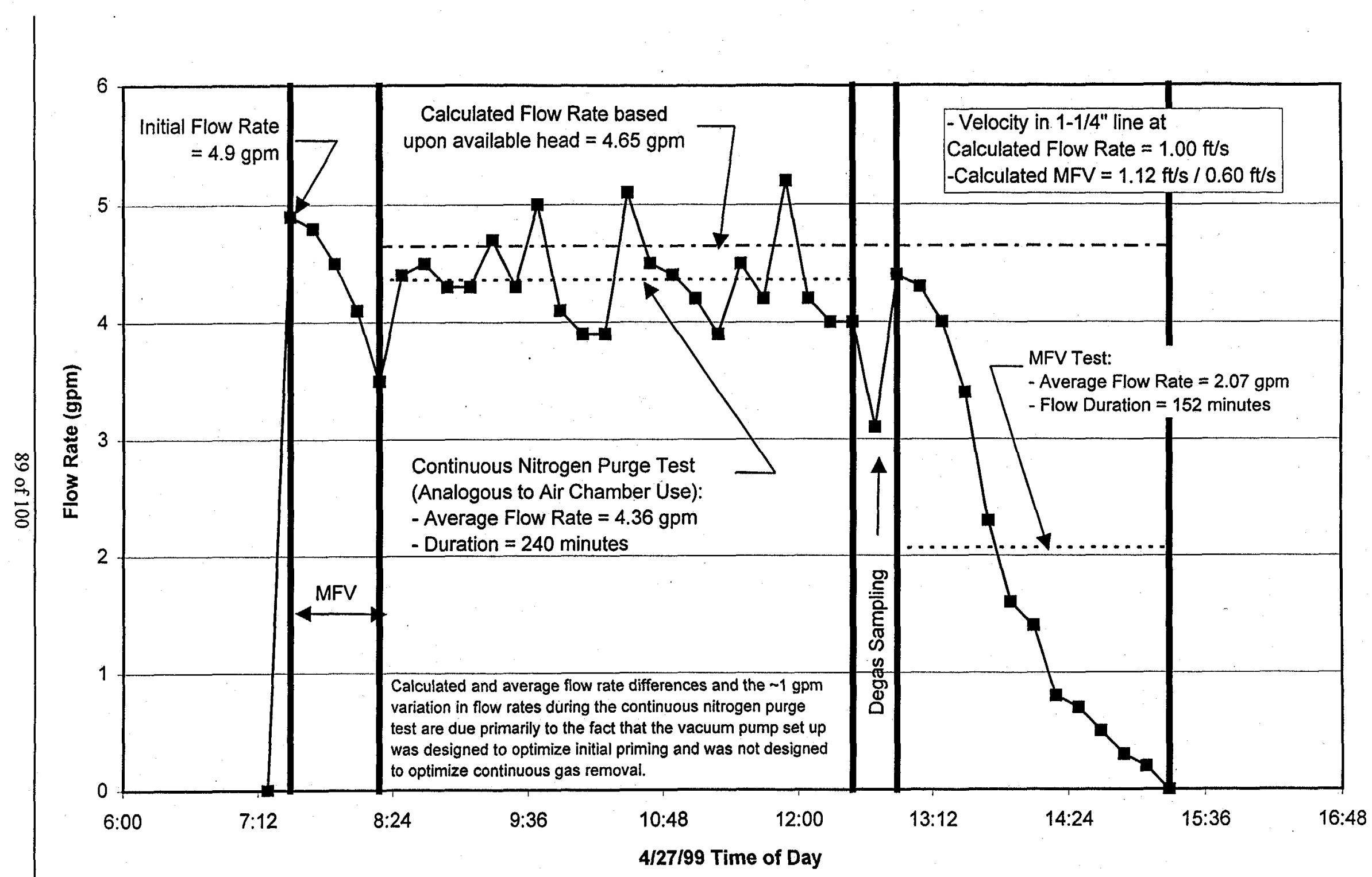

Figure 16 CNP / MFV Test 2 to 1-1/4 Inch Siphon Line - 4/27/99 Flow Rates 


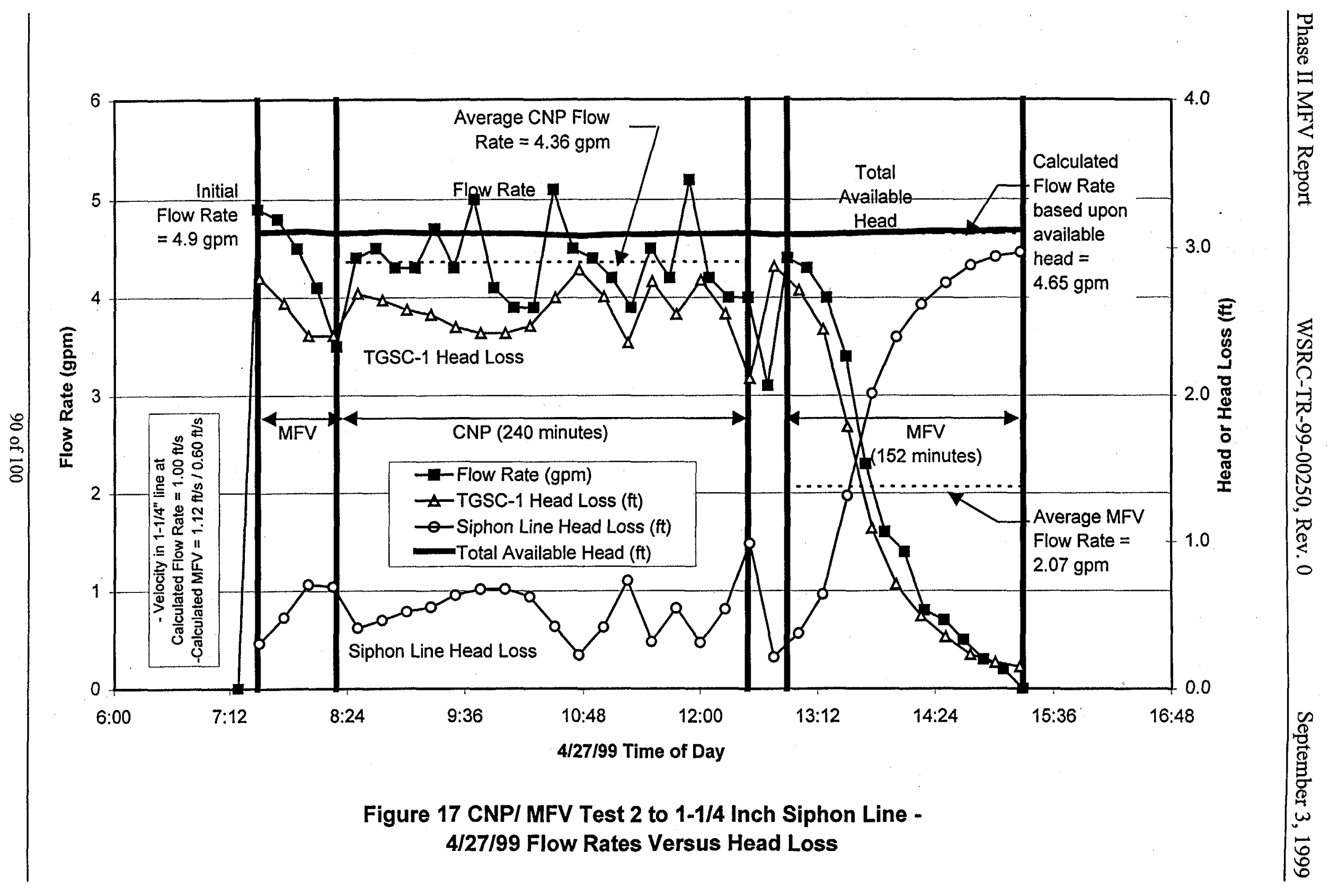




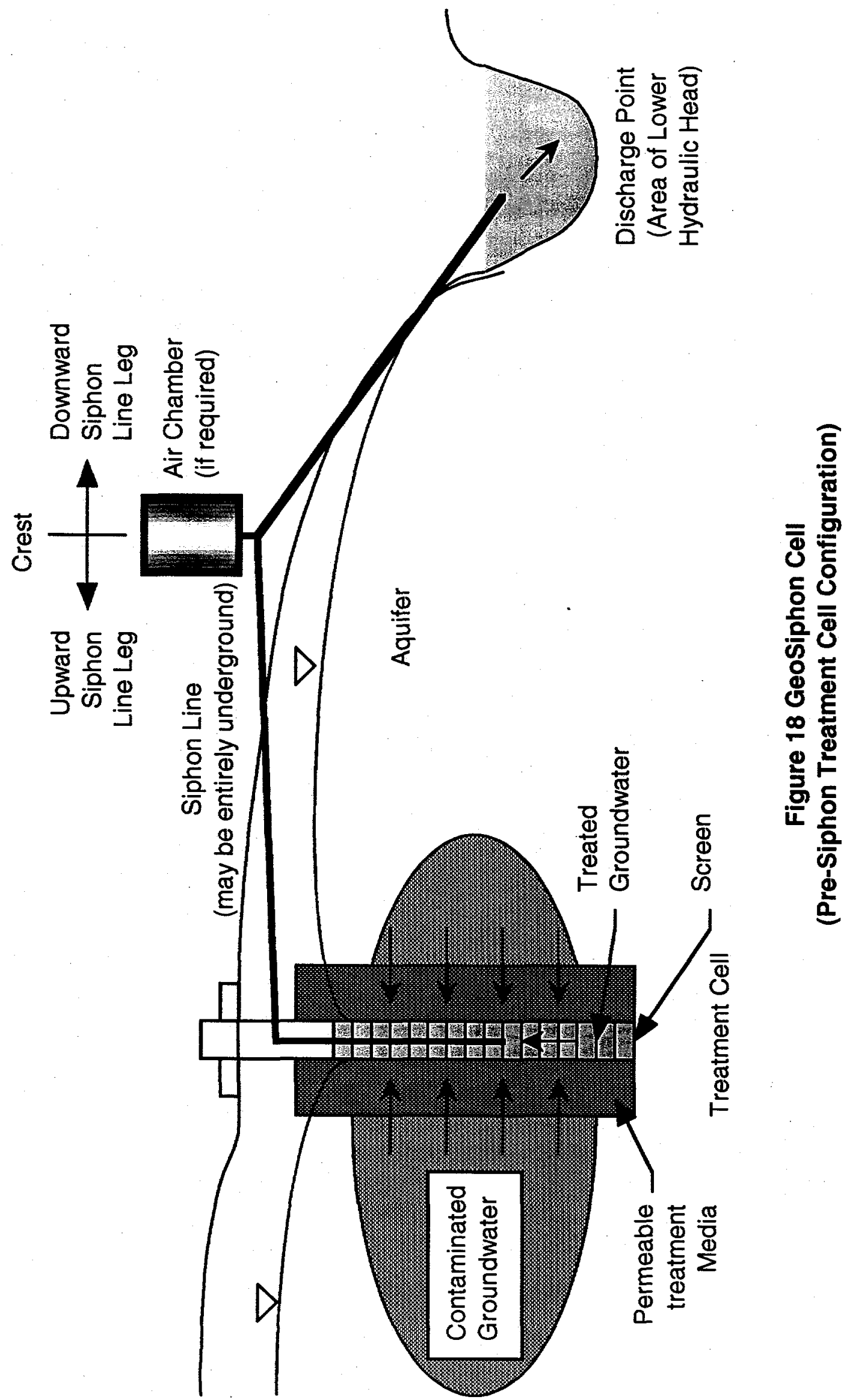




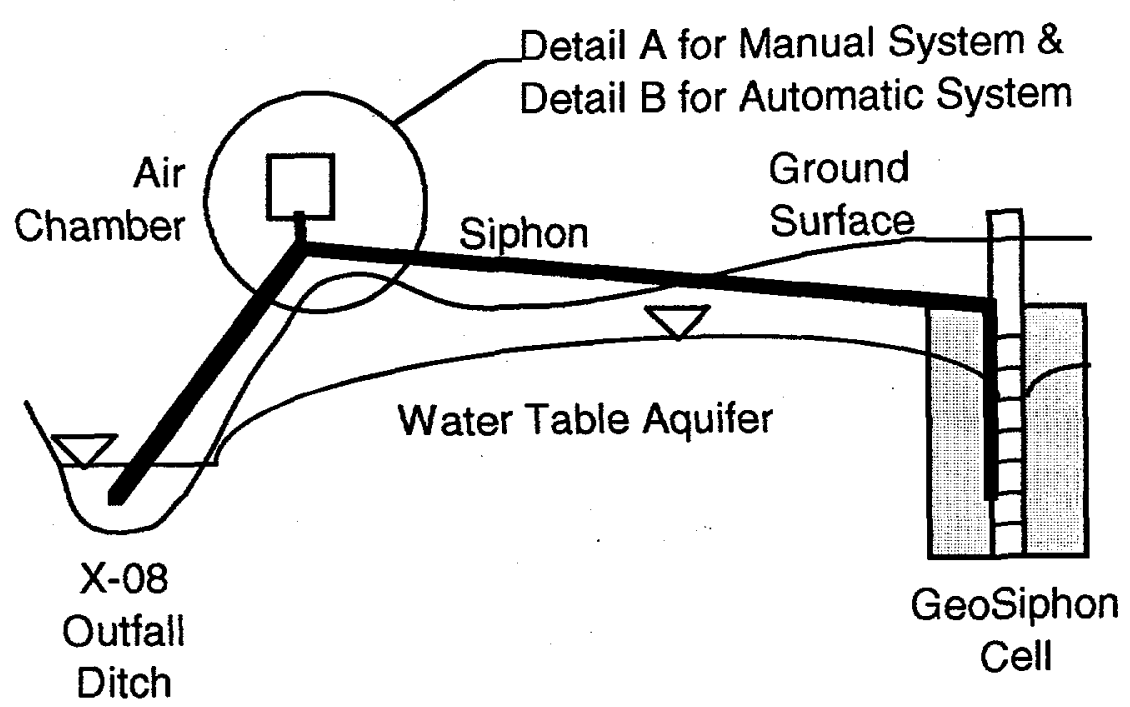

Detail A Manual Recharge

$\mathrm{N}_{2}$ Vacuum

Gas

Purge

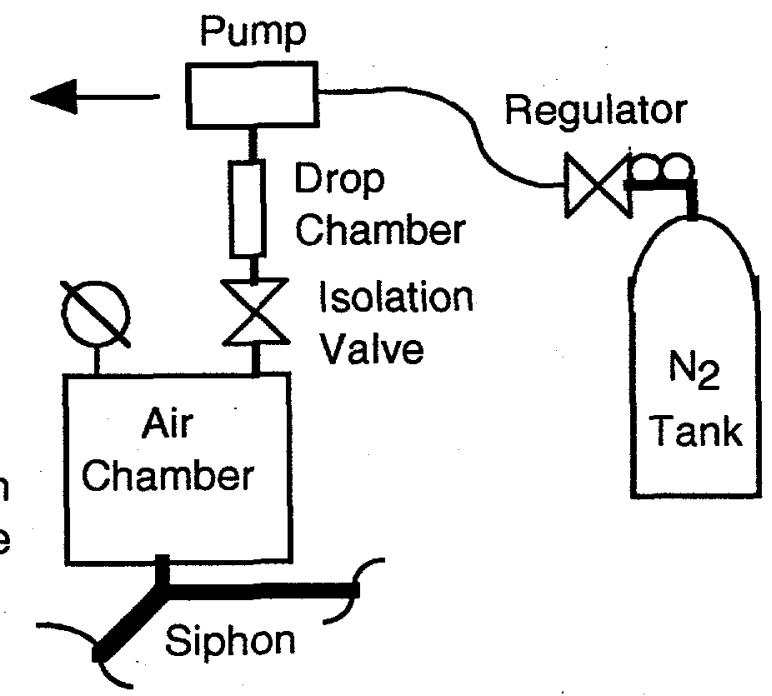

- Periodic manual purging of accumulated gas from the air chamber using a nitrogendriven vacuum pump

- The air chamber would need to be large to minimize frequency of required filling

\section{Detail B \\ Automatic Periodic Recharge}

$\mathrm{N}_{2}$ Vacuum

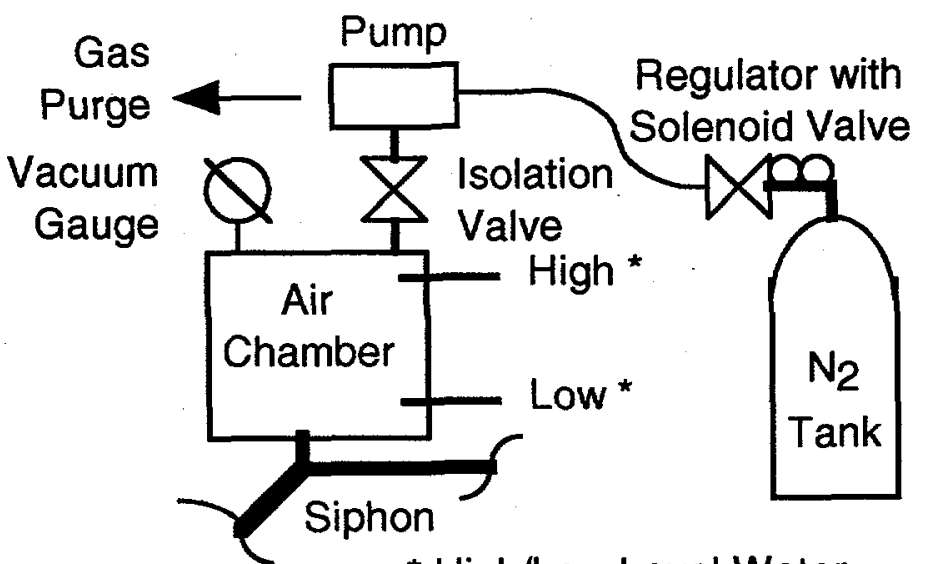

* High/Low Level Water sensor/indicatior

- Automatic purging of accumulated gas from the air chamber using a nitrogen-driven vacuum pump

- The air chamber could be fairly small; sized to need recharging approximately once a day - Solar-charged batteries could be used to operate the level sensors and the solenoid valves

Figure 19 Air Chamber Recharge with Nitrogen-Driven Vacuum Pump 


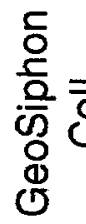

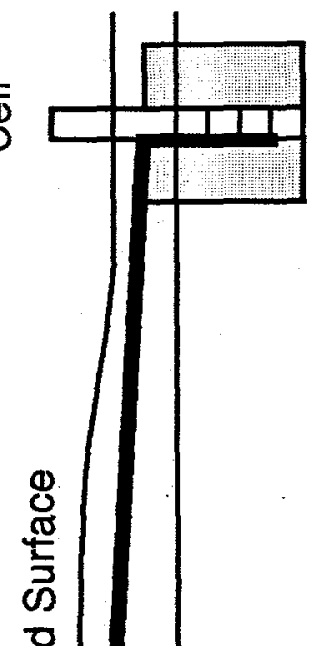

\begin{tabular}{lll}
$\infty$ & $\frac{E}{\Phi}$ & \multicolumn{5}{c}{} \\
$\frac{E}{\Phi}$ & $\frac{5}{\omega}$ & 0 \\
के & & 0
\end{tabular}

के 을

元

$\sum \frac{1}{4}$

흐흐

$\varangle \infty$

言

屯े

ธָ ธ

文

$$
\text { 은 한 }
$$

i

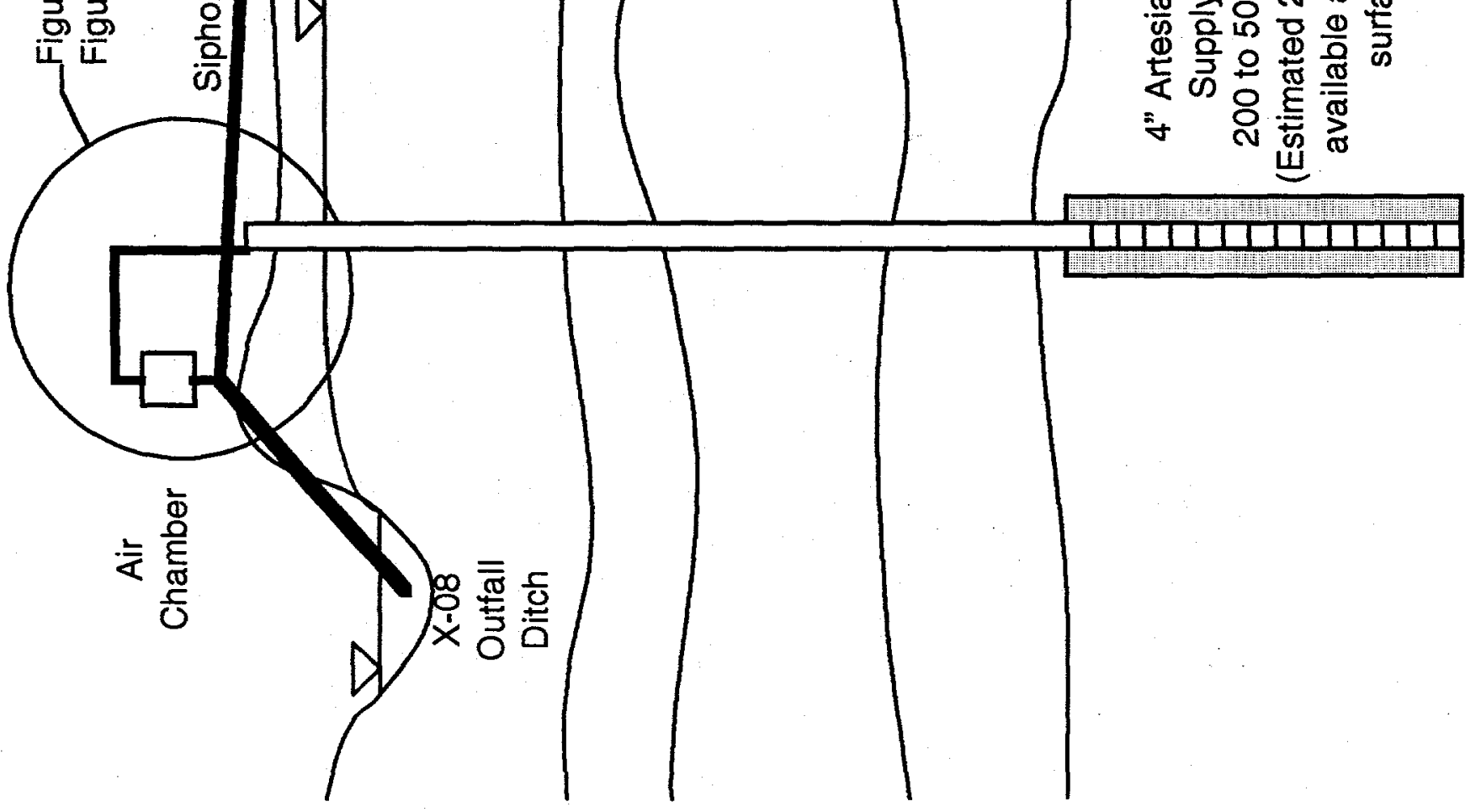

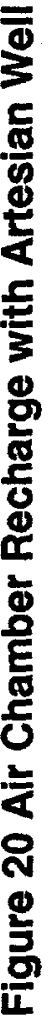

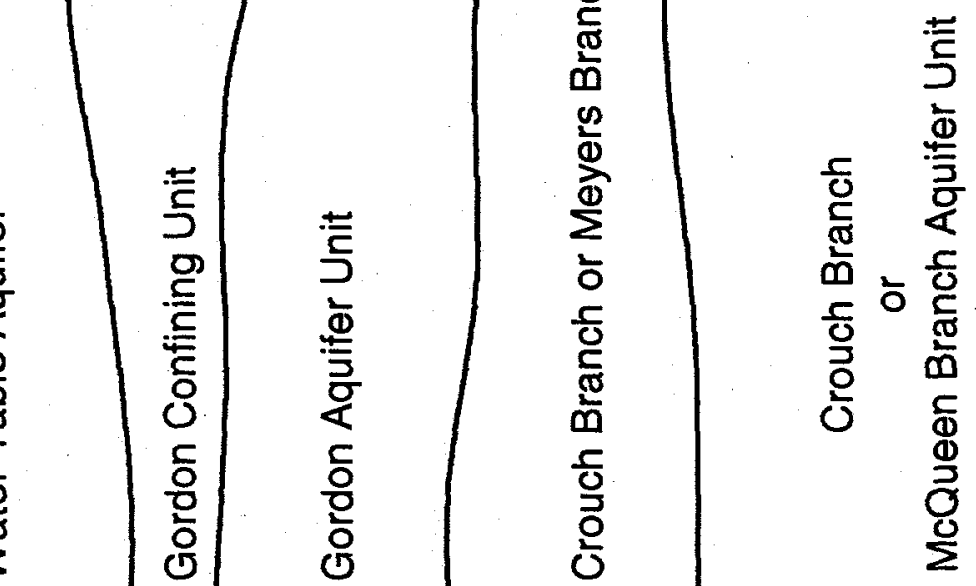

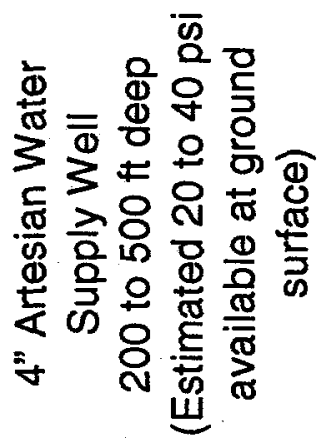
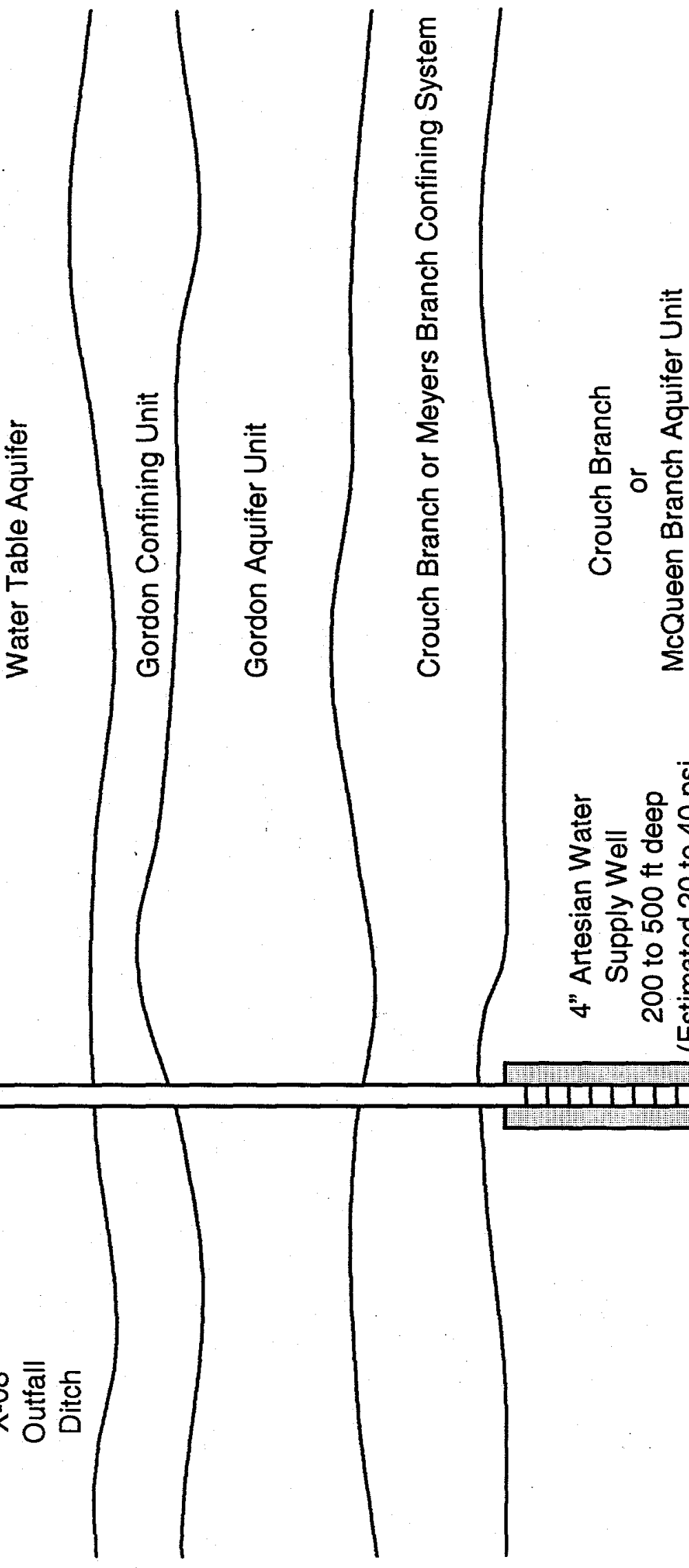

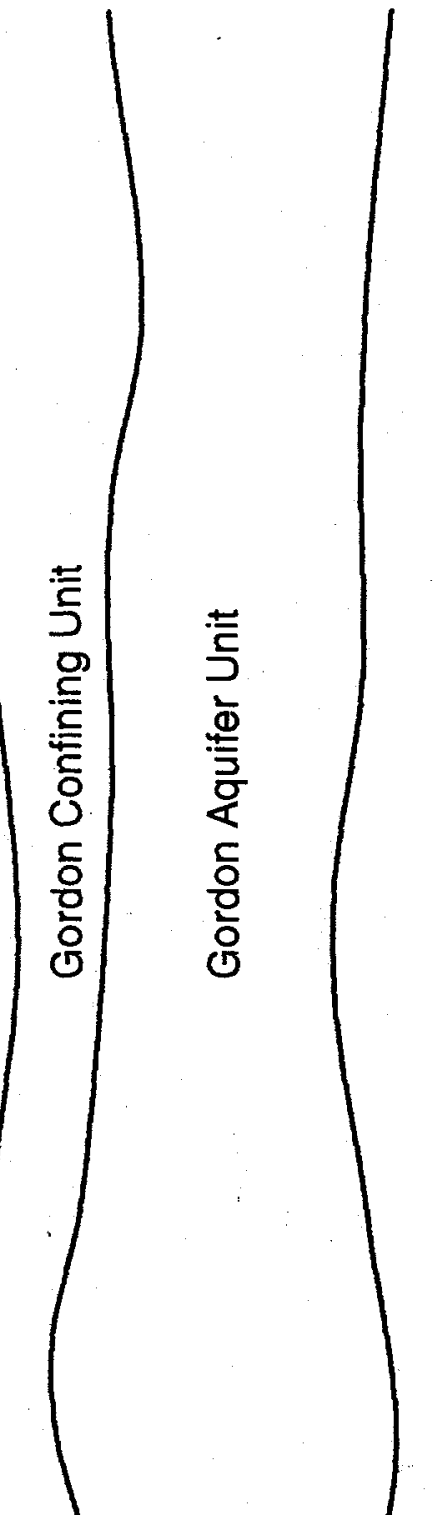




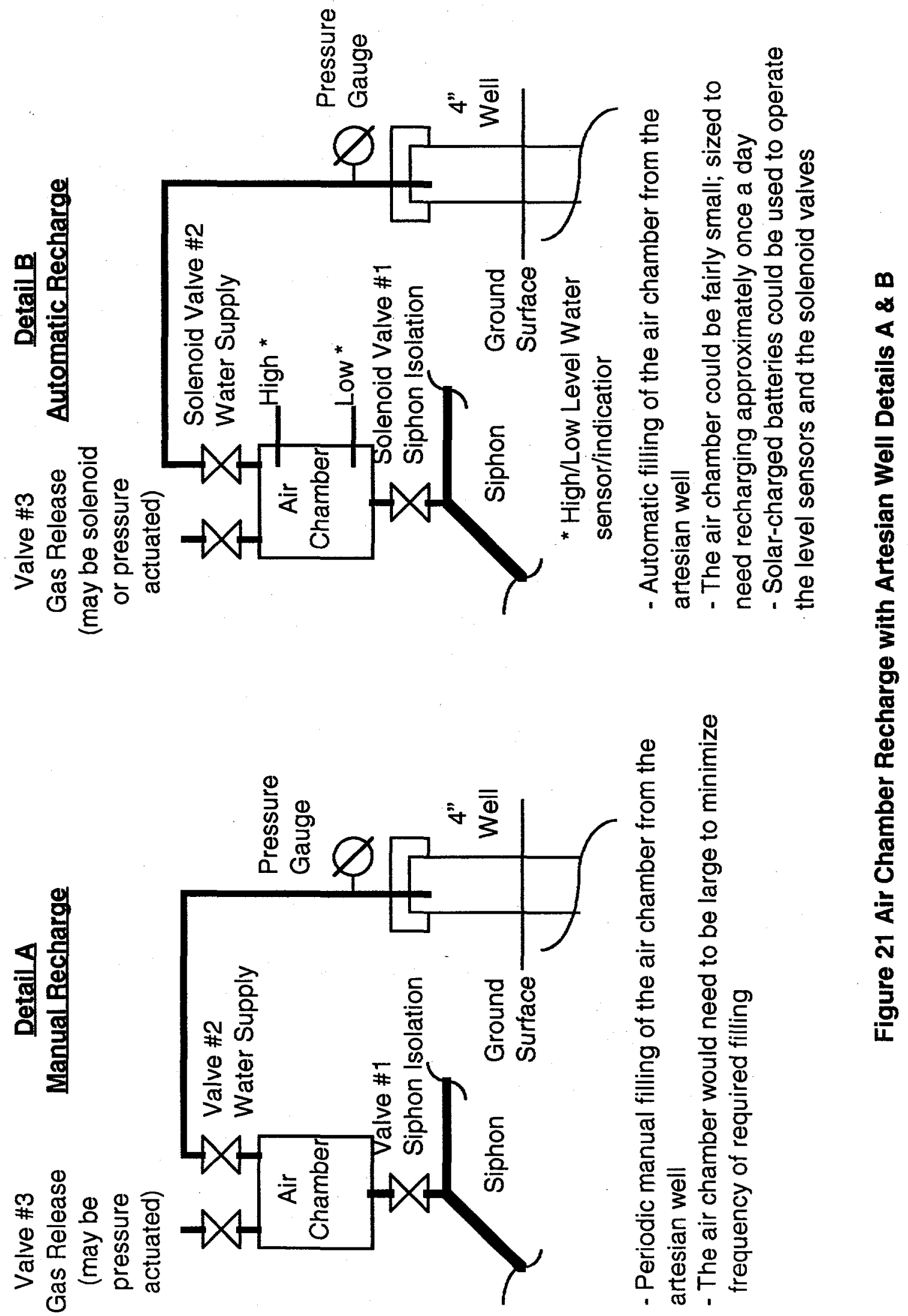




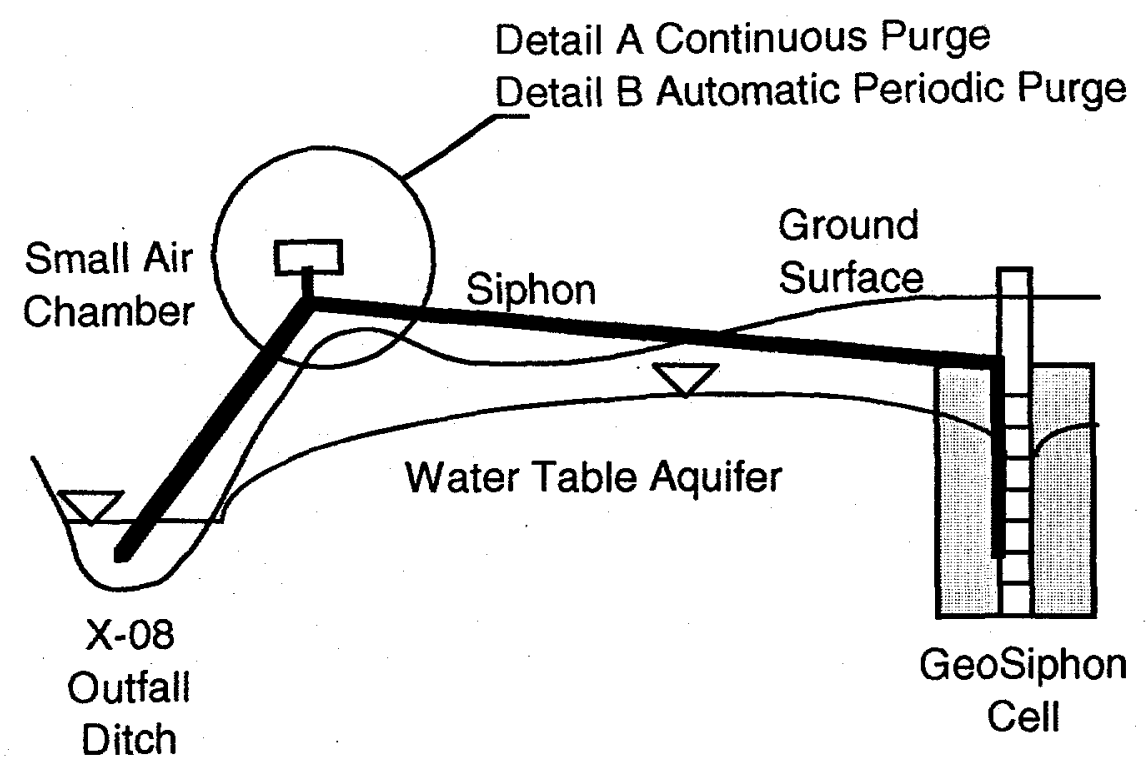

Detail A

Continuous Purge

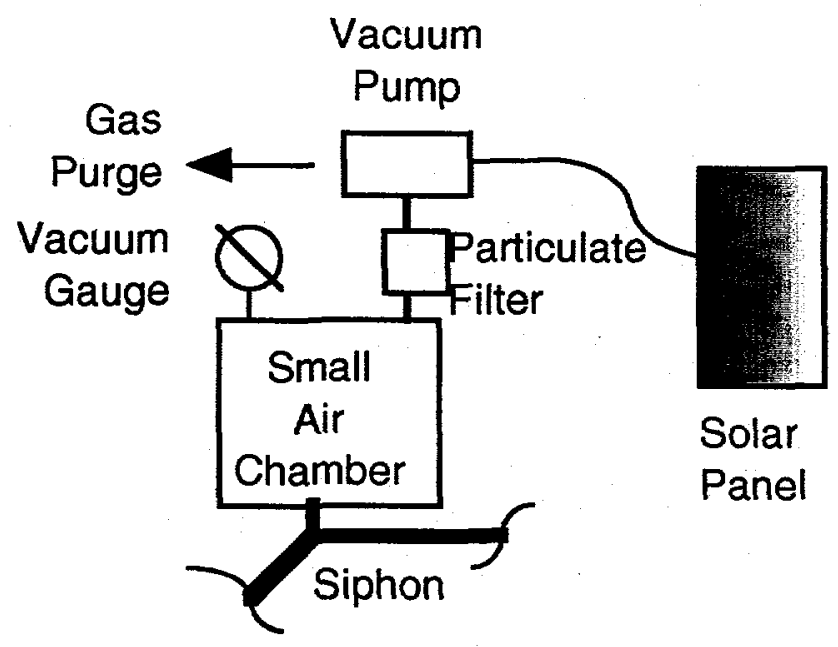

- Continuous Automatic purging of accumulated gas from the small air chamber using a solar-powered vacuum pump

- The air chamber could be very small

- May need to filter air/water between air chamber and vacuum pump to prevent particulate pluggage of the vacuum pump
Detail B Automatic Periodic Purge

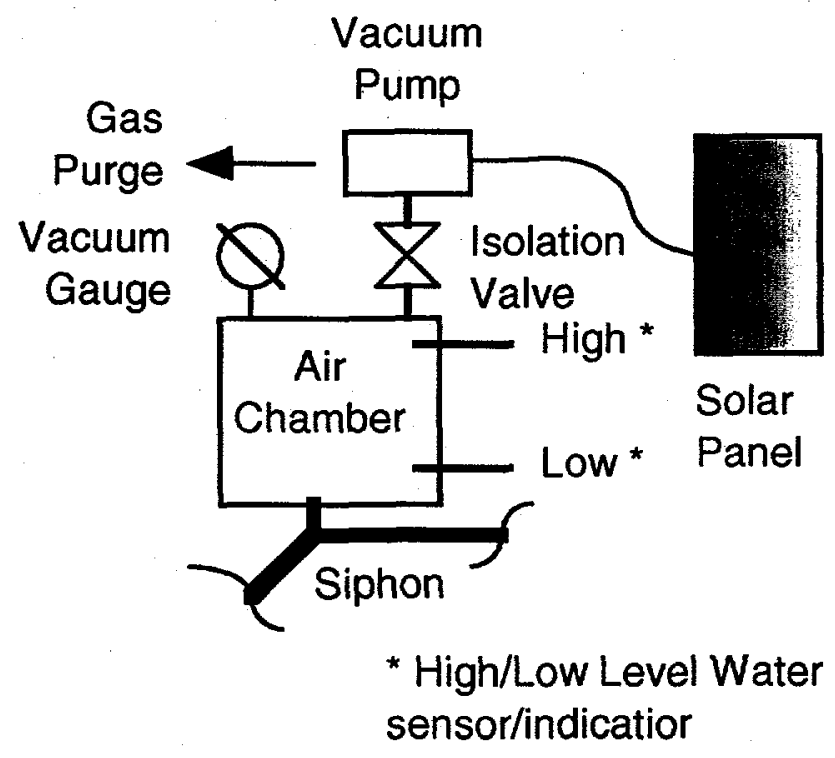

- Automatic purging of accumulated gas from the air chamber using a solar-powered vacuum pump

- The air chamber could be fairly small; sized to need recharging approximately once a day

- Solar-charged batteries could be used to operate the level sensors, solenoid valve, and vacuum pump

Figure 22 Solar Powered Vacuum Pump Purge 


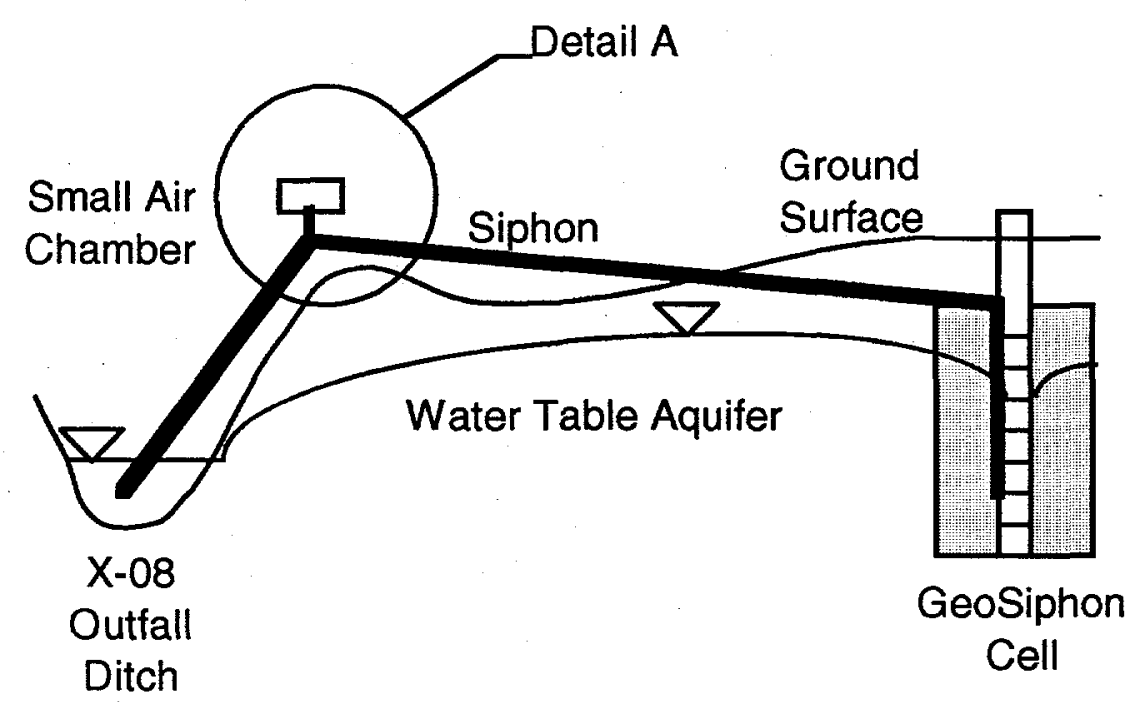

\section{Detail A \\ Continuous Nitrogen Purge}

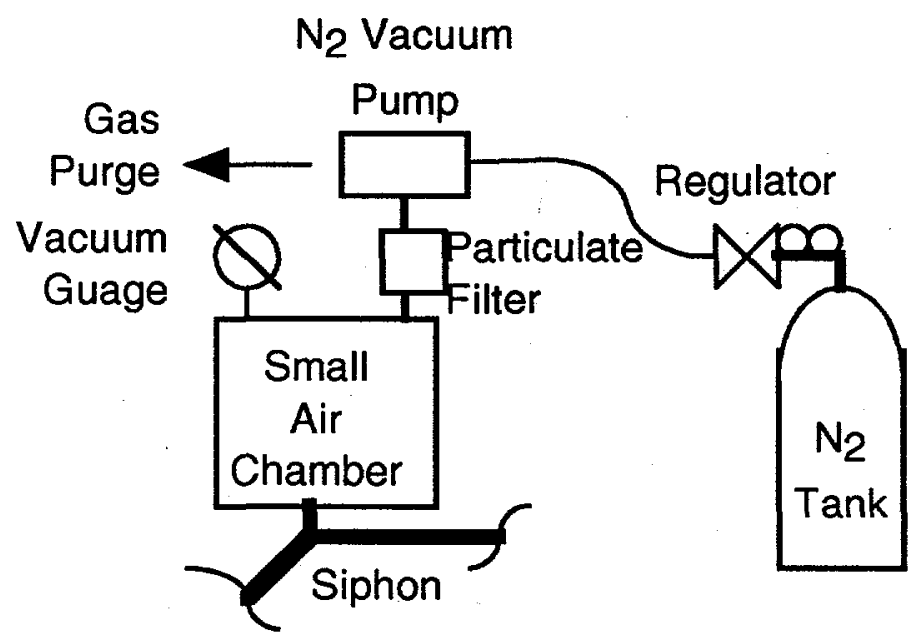

- Continuous Automatic purging of accumulated gas from the small air chamber using a nitrogen-driven vacuum pump

- The air chamber could be very small

- Must filter air/water between air chamber and nitrogen-driven vacuum pump to prevent particulate pluggage of the vacuum pump

Figure 23 Continuous Nitrogen Purge 

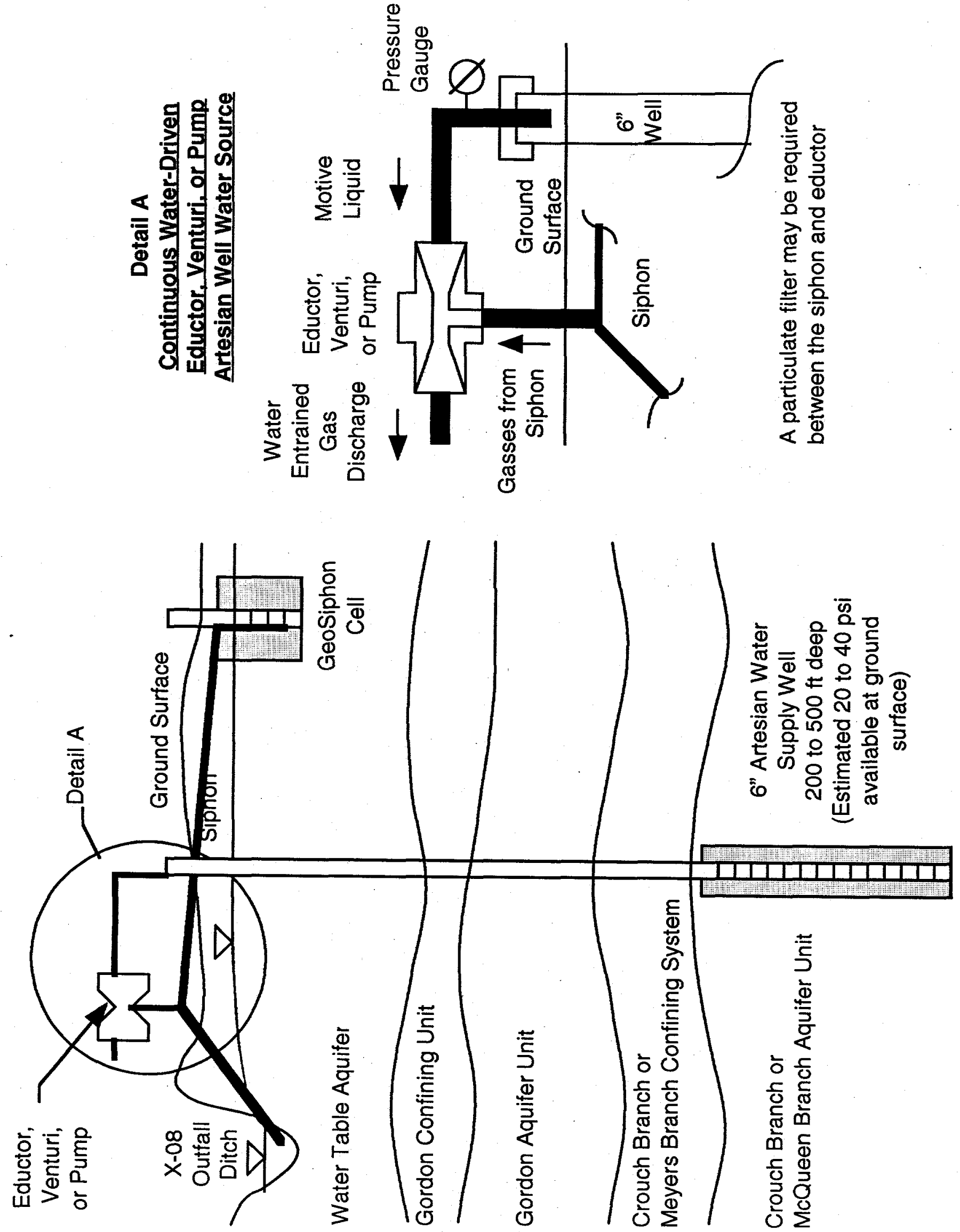


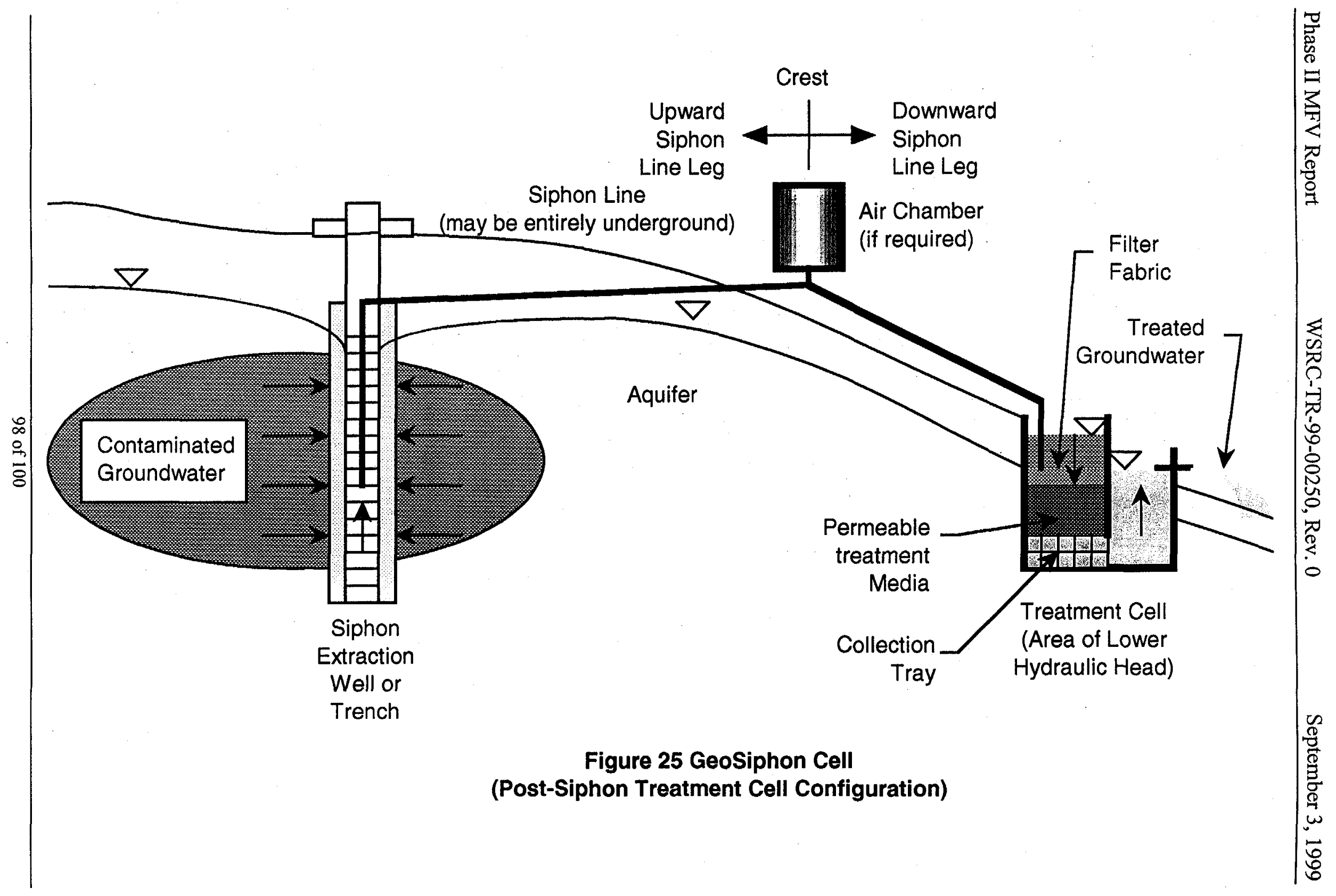




\section{APPENDICES}

APPENDIX A, FLOW RATE CALCULATIONS

APPENDIX B, CHLORINATED VOLATILE ORGANIC COMPOUND (CVOC) ANALYTICAL RESULTS

APPENDIX C, SPECIFIC CAPACITY DATA AND CALCULATIONS

APPENDIX D, DISSOLVED GAS AND GAS ANALYTICAL DATA AND

CALCULATIONS:

APPENDIX D-1, ANALYTICAL DATA

APPENDIX D-2, AVERAGED ANALYTICAL DATA

APPENDIX D-3, CALCULATED DISSOLVED GAS SATURATION CONCENTRATION IN EQUILIBRIUM WITH ATMOSPHERIC AIR

APPENDIX D-4, CALCULATED NORMALIZED EQUILIBRIUM GASPHASE CONCENTRATION IN EQUILIBRIUM WITH THE SIPHON DISCHARGE POINT AVERAGE DISSOLVED GAS CONCENTRATION

APPENDIX E, CREATIVITY COMMITTEE MEETING MINUTES 
Left Blank Intentionally 
APPENDIX A

FLOW RATE CALCULATIONS 

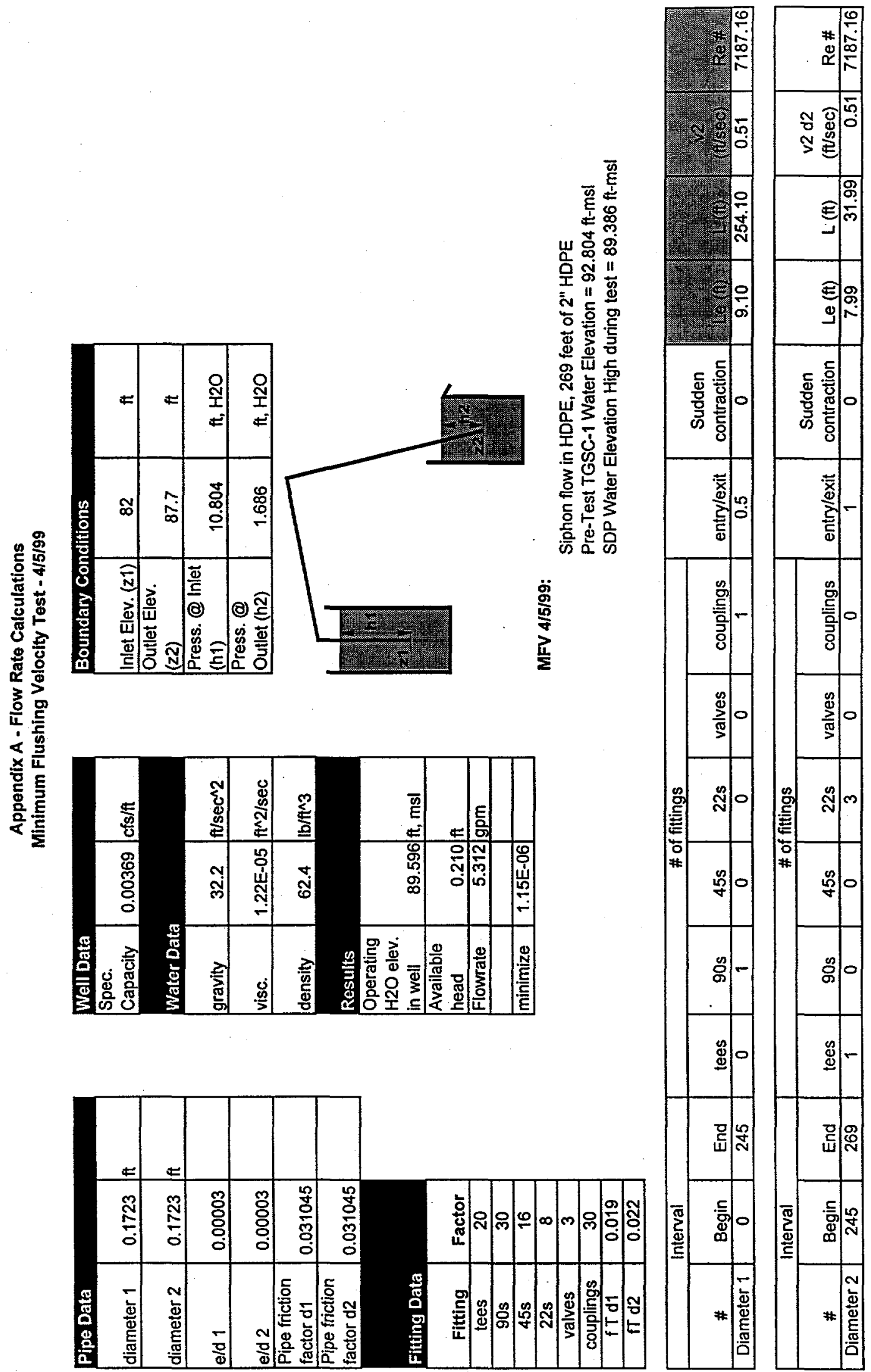

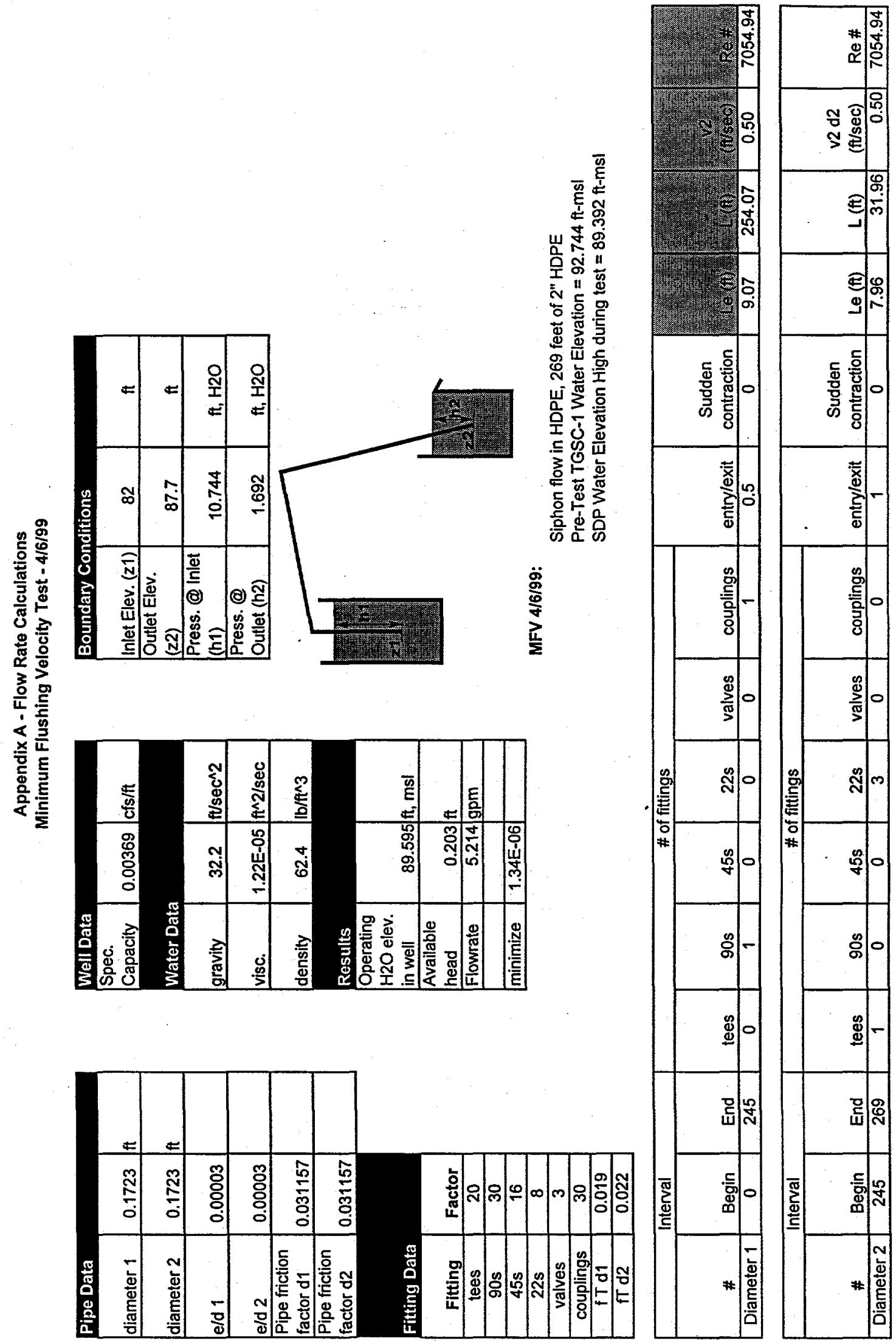

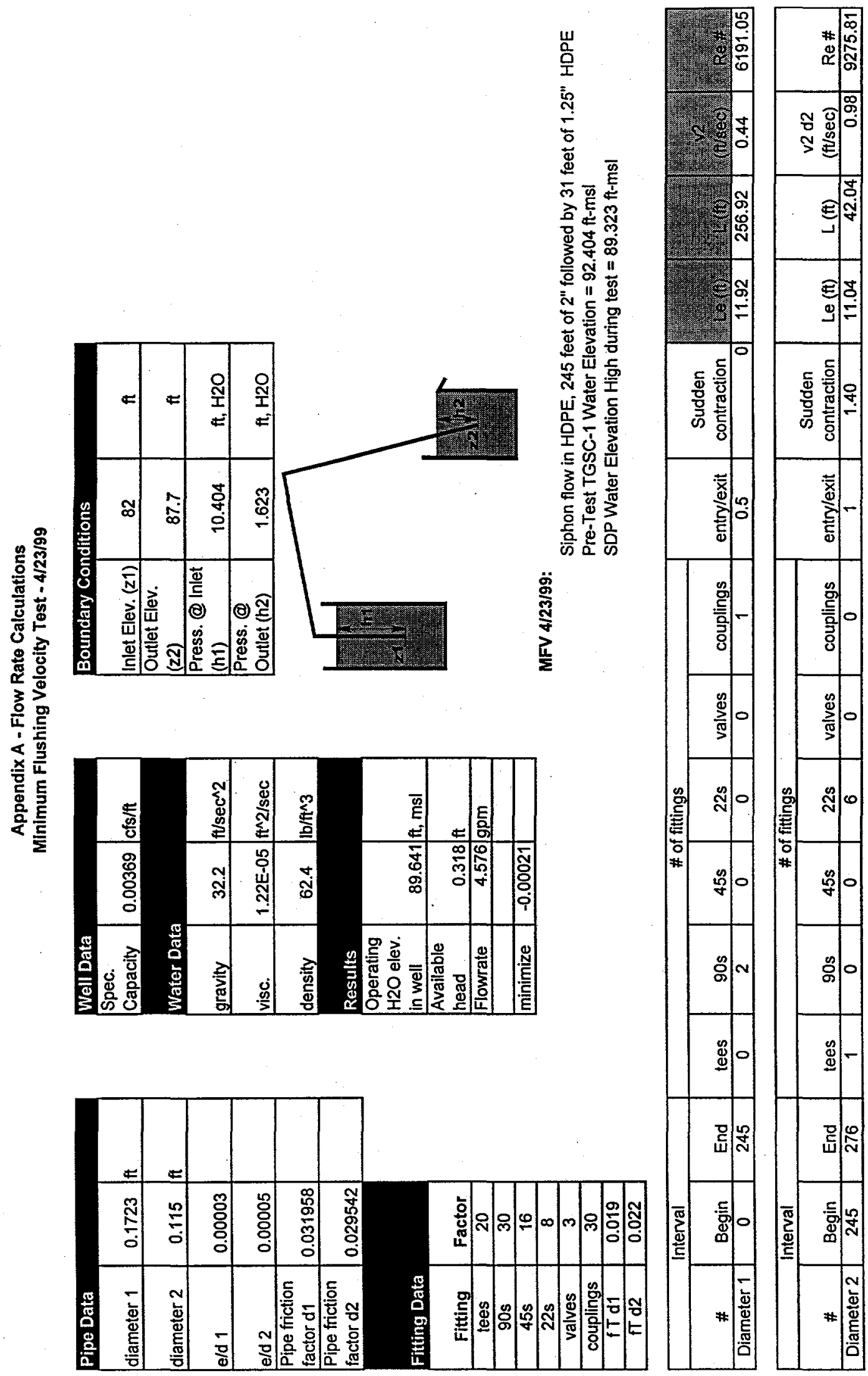

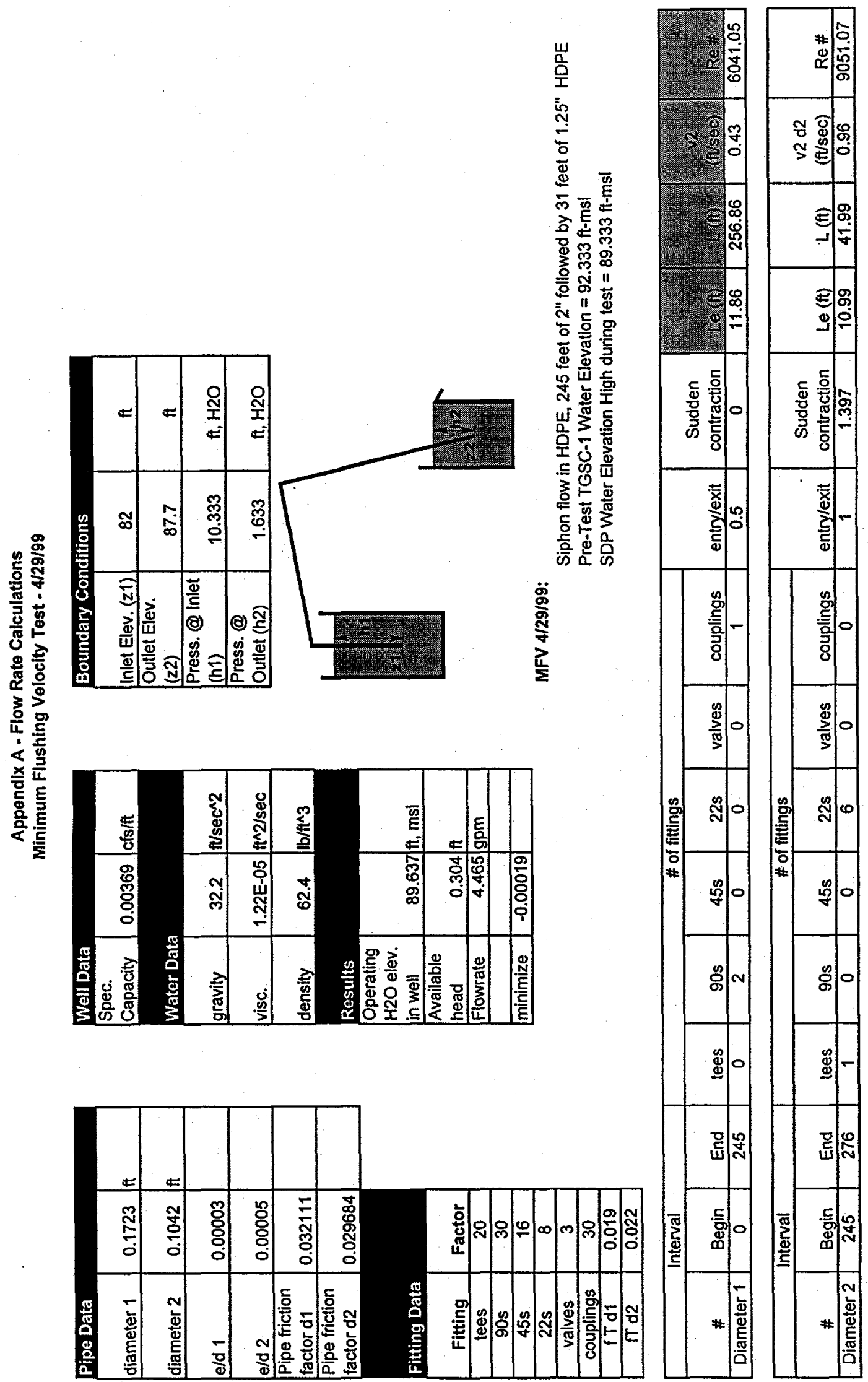

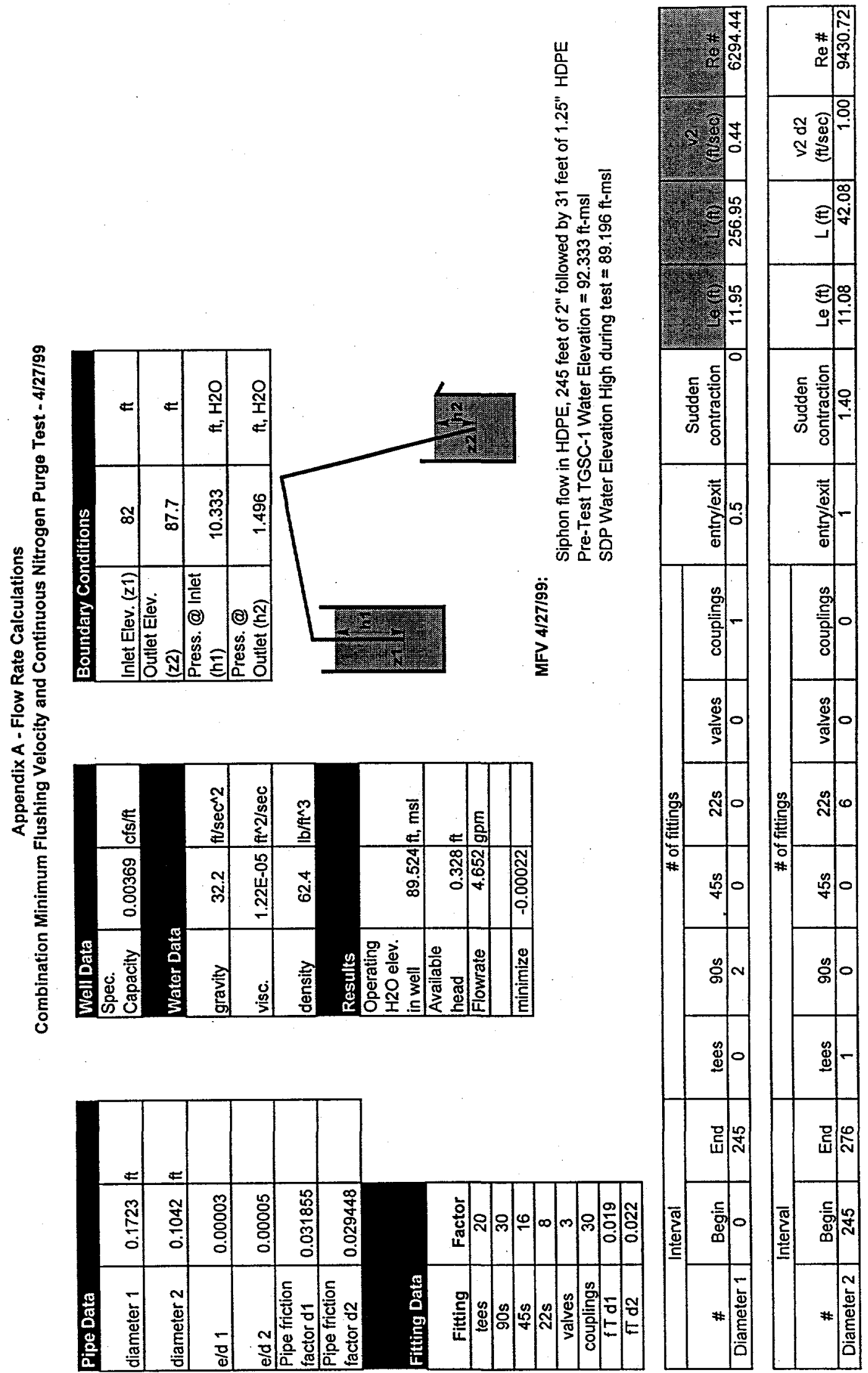


\section{APPENDIX B \\ CHLORINATED VOLATILE ORGANIC COMPOUND (CVOC) ANALYTICAL RESULTS}




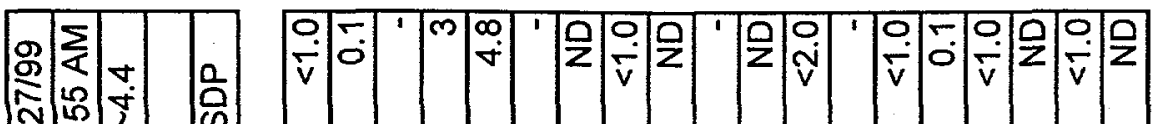
零

$8 \sum_{2}$

帘

虽

s $\sum_{0}$

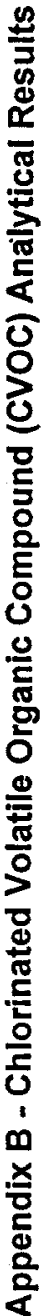

ิำ

咢

$\sum$

๑)

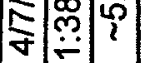

苍

E

\& 85

응

ลิ 2 ?

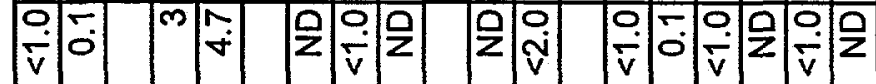

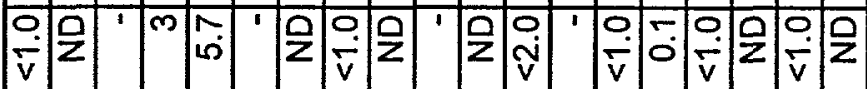

₹ 0

这응

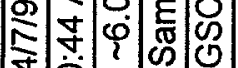

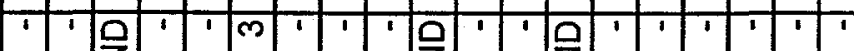

은

$8 \sum$

Nิ

$\sum_{0}^{7}$

$\vec{v}$

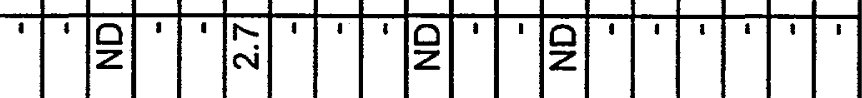

ब

$\sum_{\substack{y \\ \hline}}^{+}$

$8 \sum^{5}$

$2+$

₹ के

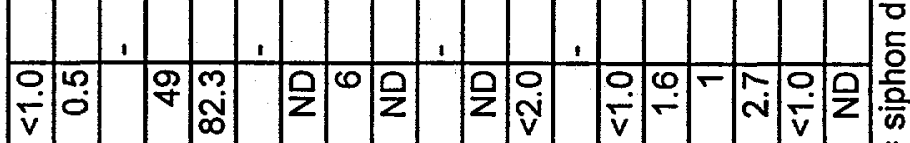

隹等

$\sum_{\substack{1 \\ \sum}}^{1}$

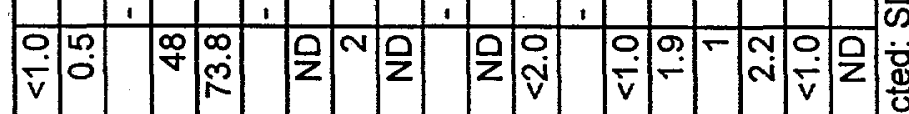

సิ

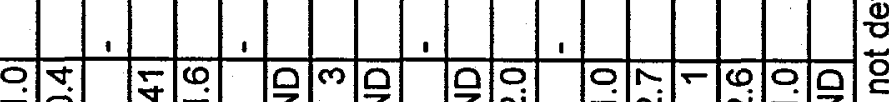

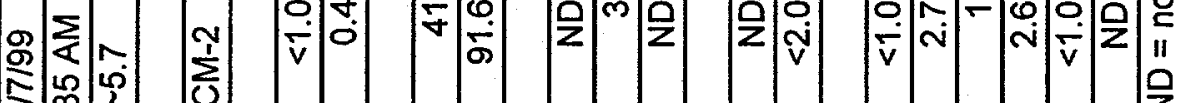

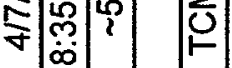

过

농

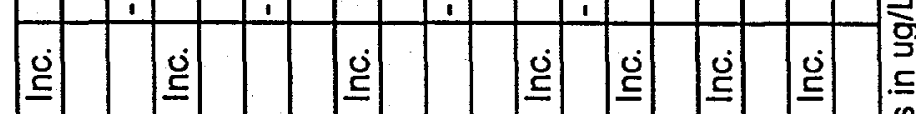

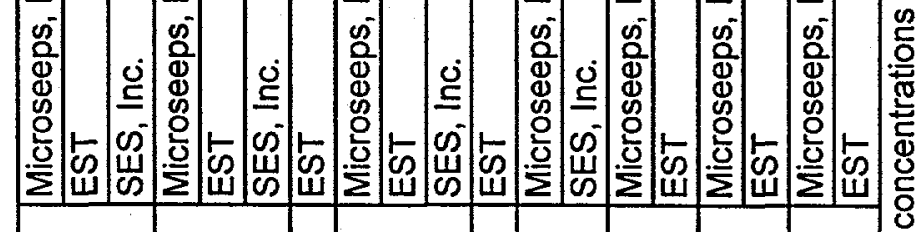

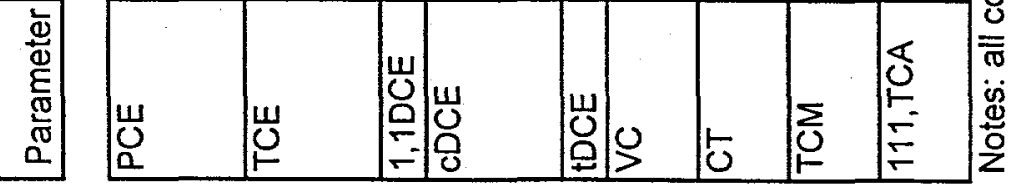


APPENDIX C

SPECIFIC CAPACITY DATA AND CALCULATIONS 


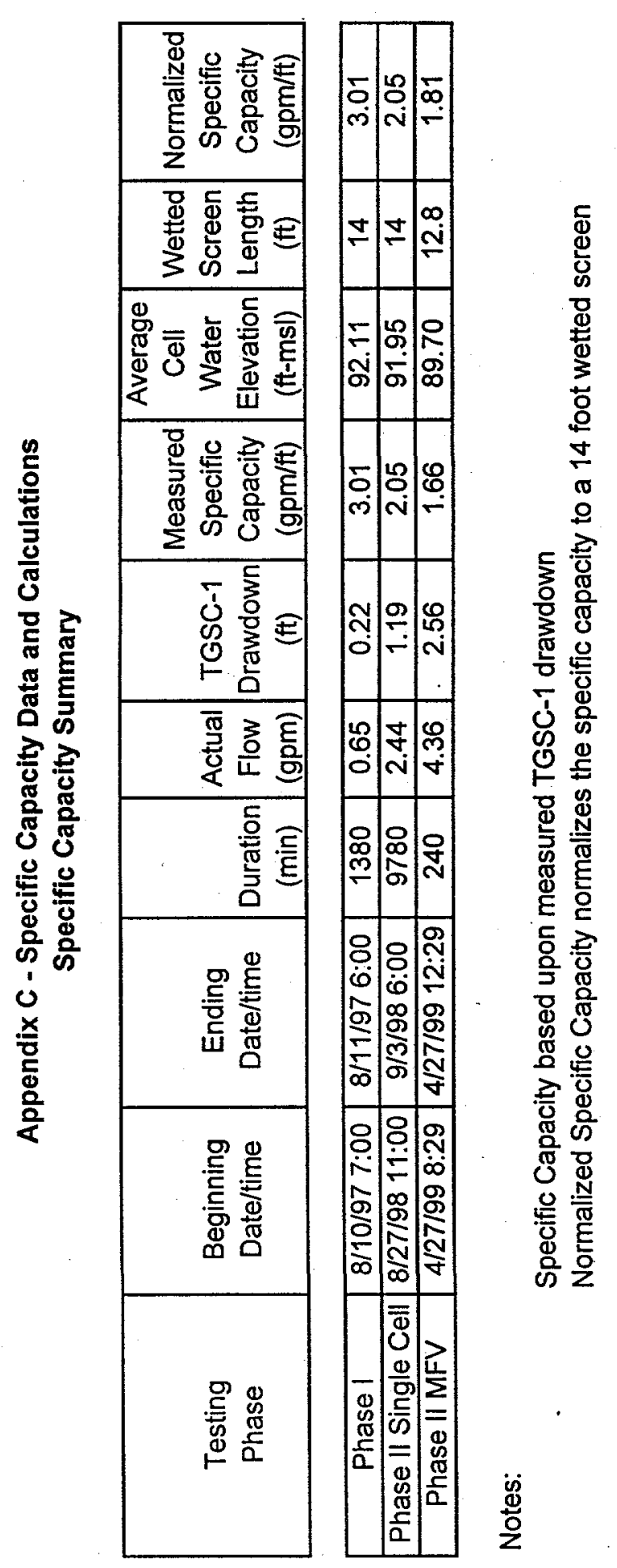




\section{Appendix C - Specific Capacity Data and Calculations} Phase I Specific Capacity

\begin{tabular}{|c|c|c|c|c|c|c|c|c|}
\hline Date; Time & $\begin{array}{l}\text { Flow } \\
\text { (gpm) }\end{array}$ & $\begin{array}{c}\text { TGSC-1 } \\
\text { Elevation } \\
\text { (ft-msl) }\end{array}$ & $\begin{array}{c}\text { Average } \\
\text { Flow } \\
\text { (gpm) }\end{array}$ & $\begin{array}{c}\text { Average } \\
\text { TGSC-1 } \\
\text { Elevation } \\
\text { (ft-msl) }\end{array}$ & $\begin{array}{c}\text { Average } \\
\text { TGSC-1 } \\
\text { Drawdown } \\
\text { (ft) }\end{array}$ & $\begin{array}{l}\text { Specific } \\
\text { Capacity } \\
(\text { gpm/ft) }\end{array}$ & $\begin{array}{c}\text { Wetted } \\
\text { Screen } \\
\text { Length } \\
(\mathrm{ft})\end{array}$ & $\begin{array}{l}\text { Normalized } \\
\text { Specific } \\
\text { Capacity } \\
(\mathrm{gpm} / \mathrm{ft})\end{array}$ \\
\hline $8 / 7 / 979: 00$ & 0.00 & 92.32 & & & & & & \\
\hline $8 / 10 / 977: 00$ & 071 & 92.12 & 0.65 & 92.11 & 0.22 & 3.01 & 14 & 3.01 \\
\hline $8 / 10 / 978: 00$ & 0.68 & 92.11 & & & & & & \\
\hline $8 / 10 / 979: 00$ & 0.66 & 92.10 & & & & & & \\
\hline $8 / 10 / 9710: 00$ & 0.67 & 92.12 & & & & & & \\
\hline $8 / 10 / 9711: 00$ & 0.67 & 92.11 & & & & & & \\
\hline $8 / 10 / 9712: 00$ & 0.66 & 92.11 & & & & & & \\
\hline $8 / 10 / 9713: 00$ & 0.66 & 92.13 & & & & & & \\
\hline $8 / 10 / 9714: 00$ & 0.66 & 92.10 & & & & & & \\
\hline $8 / 10 / 9715: 00$ & 0.66 & 92.10 & & & & & & \\
\hline $8 / 10 / 97 \quad 16: 00$ & 0.66 & 92.11 & & & & & & \\
\hline $8 / 10 / 9717: 00$ & 0.65 & 92.11 & & & & & & \\
\hline $8 / 10 / 9718: 00$ & 0.65 & 92.10 & & & & & & \\
\hline $8 / 10 / 9719: 00$ & 0.64 & 92.10 & & & & & & \\
\hline $8 / 10 / 9720: 00$ & 0.64 & 92.09 & & & & & & \\
\hline $8 / 10 / 9721: 00$ & 0.64 & 92.11 & & & & & & \\
\hline $8 / 10 / 9722: 00$ & 0.65 & 92.09 & & & & & & \\
\hline $8 / 10 / 9723: 00$ & 0.65 & 92.09 & & & & & & \\
\hline $8 / 11 / 970: 00$ & 0.64 & 92.10 & & & & & & \\
\hline $8 / 11 / 971: 00$ & 0.64 & 92.11 & & & & & & \\
\hline $8 / 11 / 972: 00$ & 0.63 & 92.11 & & & & & & \\
\hline $8 / 11 / 973: 00$ & 0.63 & 92.11 & & & & & & \\
\hline $8 / 11 / 974: 00$ & 0.63 & 92.13 & & & & & & \\
\hline $8 / 11 / 975: 00$ & 0.62 & 92.11 & & & & & & \\
\hline $8 / 11 / 976: 00$ & 0.62 & 92.15 & & & & & & \\
\hline Average & 0.65 & 92.11 & & & & & & \\
\hline
\end{tabular}




\section{Appendix C - Specific Capacity Data and Calculations Phase II Single-Cell Specific Capacity}

\begin{tabular}{|c|c|c|c|c|c|c|c|c|c|}
\hline Date; Time & $\begin{array}{l}\text { Flow } \\
\text { (gpm) }\end{array}$ & Date; Time & $\begin{array}{c}\text { TGSC-1 } \\
\text { Elevation } \\
\text { (ft-msl) }\end{array}$ & $\begin{array}{c}\text { Average } \\
\text { Flow } \\
\text { (gpm) }\end{array}$ & \begin{tabular}{|c|} 
Average \\
TGSC-1 \\
Elevation \\
$(\mathrm{ft}-\mathrm{msl})$ \\
\end{tabular} & $\begin{array}{c}\text { Average } \\
\text { TGSC-1 } \\
\text { Drawdown } \\
\text { (ft) } \\
\end{array}$ & $\begin{array}{l}\text { Specific } \\
\text { Capacity } \\
(\mathrm{gpm} / \mathrm{ft})\end{array}$ & $\begin{array}{c}\text { Wetted } \\
\text { Screen } \\
\text { Length } \\
\text { (ft) } \\
\end{array}$ & $\begin{array}{c}\text { Normalized } \\
\text { Specific } \\
\text { Capacity } \\
\text { (gpm/ft) }\end{array}$ \\
\hline 8/27/989:00 & 0.00 & $8 / 27 / 989: 00$ & 93.14 & & & & & & \\
\hline $8 / 27 / 9811: 00$ & 2.69 & $8 / 27 / 98 \quad 11: 00$ & 91.97 & 2.44 & 91.95 & 1.19 & 2.05 & 14 & 2.05 \\
\hline $8 / 27 / 98 \quad 11: 30$ & 2.66 & $8 / 27 / 98 \quad 12: 00$ & 91.96 & & & & & & \\
\hline $8 / 27 / 98 \quad 12: 00$ & 2.63 & $8 / 27 / 9813: 00$ & 91.95 & & & & & & \\
\hline $8 / 27 / 98 \quad 12: 30$ & 2.62 & $8 / 27 / 98 \quad 14: 00$ & 91.94 & & & & & & \\
\hline $8 / 27 / 98 \quad 13: 00$ & 2.59 & $8 / 27 / 9815: 00$ & 91.94 & & & & & & \\
\hline $8 / 27 / 98 \quad 13: 30$ & 2.57 & $8 / 27 / 9816: 00$ & 91.94 & & & & & & \\
\hline $8 / 27 / 98 \quad 14: 00$ & 2.55 & $8 / 27 / 9817: 00$ & 91.93 & & & & & & \\
\hline $8 / 27 / 98 \quad 14: 30$ & 2.54 & $8 / 27 / 9818: 00$ & 91.93 & & & & & & \\
\hline $8 / 27 / 98 \quad 15: 00$ & 2.53 & $8 / 27 / 9819: 00$ & 91.93 & & & & & & \\
\hline $8 / 27 / 98 \quad 15: 30$ & 2.51 & $8 / 27 / 9820: 00$ & 91.93 & & & & & & \\
\hline $8 / 27 / 9816: 00$ & 2.52 & $8 / 27 / 9821: 00$ & 91.93 & & & & & & \\
\hline $8 / 27 / 98 \quad 16: 30$ & 2.51 & $8 / 27 / 9822: 00$ & 91.93 & & & & & & \\
\hline $8 / 27 / 98 \quad 17: 00$ & 2.50 & $8 / 27 / 9823: 00$ & 91.93 & & & & & & \\
\hline $8 / 27 / 98 \quad 17: 30$ & 2.51 & $8 / 28 / 980: 00$ & 91.94 & & & & & & \\
\hline $8 / 27 / 98 \quad 18: 00$ & 2.51 & $8 / 28 / 981: 00$ & 91.94 & & & & & & \\
\hline $8 / 27 / 98 \quad 18: 30$ & 2.51 & $8 / 28 / 982: 00$ & 91.94 & & & & & & \\
\hline $8 / 27 / 9819: 00$ & 2.52 & $8 / 28 / 983: 00$ & 91.94 & & & & & & \\
\hline $8 / 27 / 98 \quad 19: 30$ & 2.52 & $8 / 28 / 984: 00$ & 91.94 & & & & & & \\
\hline $8 / 27 / 9820: 00$ & 2.53 & $8 / 28 / 985: 00$ & 91.94 & & & & & & \\
\hline $8 / 27 / 9820: 30$ & 2.52 & $8 / 28 / 986: 00$ & 91.94 & & & & & & \\
\hline $8 / 27 / 9821: 00$ & 2.53 & $8 / 28 / 987: 00$ & 91.94 & & & & & & \\
\hline $8 / 27 / 9821: 30$ & 2.53 & 8/28/98 8:00 & 91.94 & & & & & & \\
\hline $8 / 27 / 9822: 00$ & 2.54 & $8 / 28 / 989: 00$ & 91.94 & & & & & & \\
\hline $8 / 27 / 9822: 30$ & 2.53 & $8 / 28 / 98 \quad 10: 00$ & 91.93 & & & & & & \\
\hline $8 / 27 / 9823: 00$ & 2.54 & $8 / 28 / 9811: 00$ & 91.93 & & & & & & \\
\hline $8 / 27 / 9823: 30$ & 2.53 & $8 / 28 / 98 \quad 12: 00$ & 91.92 & & & & & & \\
\hline $8 / 28 / 980: 00$ & 2.54 & $8 / 28 / 98 \quad 13: 00$ & 91.92 & & & & & & \\
\hline $8 / 28 / 980: 30$ & 2.54 & $8 / 28 / 9814: 00$ & 91.92 & & & & & & \\
\hline $8 / 28 / 981: 00$ & 2.55 & $8 / 28 / 98 \quad 15: 00$ & 91.91 & & & & & & \\
\hline $8 / 28 / 981: 30$ & 2.57 & $8 / 28 / 98 \quad 16: 00$ & 91.92 & & & & & & \\
\hline $8 / 28 / 982: 00$ & 2.57 & $8 / 28 / 98 \quad 17: 00$ & 91.92 & & & & & & \\
\hline $8 / 28 / 982: 30$ & 2.56 & $8 / 28 / 98 \quad 18: 00$ & 91.91 & & & & & & \\
\hline 8/28/98 3:00 & 2.58 & $8 / 28 / 9819: 00$ & 91.93 & & & & & & \\
\hline $8 / 28 / 983: 30$ & 2.58 & $8 / 28 / 9820: 00$ & 91.92 & & & & & & \\
\hline $8 / 28 / 984: 00$ & 2.58 & $8 / 28 / 9821: 00$ & 91.93 & & & & & & \\
\hline
\end{tabular}




\section{Appendix C - Specific Capacity Data and Calculations \\ Phase II Single-Cell Specific Capacity (continued)}

\begin{tabular}{|c|c|c|c|c|c|c|c|c|c|}
\hline Date; Time & $\begin{array}{c}\text { Flow } \\
(\mathrm{gpm})\end{array}$ & Date; Time & $\begin{array}{c}\text { TGSC-1 } \\
\text { Elevation } \\
\text { (ft-msl) } \\
\end{array}$ & $\begin{array}{c}\text { Average } \\
\text { Flow } \\
\text { (gpm) }\end{array}$ & \begin{tabular}{|c|} 
Average \\
TGSC-1 \\
Elevation \\
$(\mathrm{ft}-\mathrm{msl})$ \\
\end{tabular} & $\begin{array}{l}\text { Average } \\
\text { TGSC-1 } \\
\text { Drawdown } \\
\text { (ft) }\end{array}$ & $\begin{array}{l}\text { Specific } \\
\text { Capacity } \\
\text { (gpm/ft) } \\
\end{array}$ & $\begin{array}{c}\text { Wetted } \\
\text { Screen } \\
\text { Length } \\
\text { (ft) }\end{array}$ & $\begin{array}{c}\text { Normalized } \\
\text { Specific } \\
\text { Capacity } \\
\text { (gpm/ft) }\end{array}$ \\
\hline $8 / 28 / 984: 30$ & 2.59 & $8 / 28 / 9822: 00$ & 91.93 & & & & & & \\
\hline $8 / 28 / 985: 00$ & 2.59 & $8 / 28 / 9823: 00$ & 91.93 & & & & & & \\
\hline $8 / 28 / 985: 30$ & 2.58 & $8 / 29 / 980: 00$ & 91.93 & & & & & & \\
\hline $8 / 28 / 986: 00$ & 2.59 & $8 / 29 / 981: 00$ & 91.94 & & & & & & \\
\hline $8 / 28 / 986: 30$ & 2.59 & $8 / 29 / 982: 00$ & 91.95 & & & & & & \\
\hline $8 / 28 / 987: 00$ & 2.60 & $8 / 29 / 983: 00$ & 91.97 & & & & & & \\
\hline $8 / 28 / 987: 30$ & 2.61 & $8 / 29 / 984: 00$ & 91.97 & & & & & & \\
\hline $8 / 28 / 988: 00$ & 2.41 & $8 / 29 / 985: 00$ & 91.97 & & & & & & \\
\hline $8 / 28 / 988: 30$ & 2.63 & $8 / 29 / 986: 00$ & 91.97 & & & & & & \\
\hline $8 / 28 / 989: 00$ & 2.61 & $8 / 29 / 987: 00$ & 91.97 & & & & & & \\
\hline $8 / 28 / 989: 30$ & 2.58 & $8 / 29 / 988: 00$ & 91.97 & & & & & & \\
\hline $8 / 28 / 98 \quad 10: 00$ & 2.56 & 8/29/989:00 & 91.97 & & & & & & \\
\hline $8 / 28 / 98 \quad 10: 30$ & 2.55 & $8 / 29 / 98 \quad 10: 00$ & 91.97 & & & & & & \\
\hline $8 / 28 / 9811: 00$ & 2.52 & $8 / 29 / 9811: 00$ & 91.97 & & & & & & \\
\hline $8 / 28 / 98 \quad 11: 30$ & 2.51 & $8 / 29 / 9812: 00$ & 91.97 & & & & & & \\
\hline $8 / 28 / 98 \quad 12: 00$ & 2.49 & $8 / 29 / 9813: 00$ & 91.96 & & & & & & \\
\hline $8 / 28 / 9812: 30$ & 2.50 & $8 / 29 / 9814: 00$ & 91.95 & & & & & & \\
\hline $8 / 28 / 9813: 00$ & 2.48 & $8 / 29 / 98 \quad 15: 00$ & 91.95 & & & & & & \\
\hline $8 / 28 / 98 \quad 13: 30$ & 2.45 & $8 / 29 / 9816: 00$ & 92.28 & & & & & & \\
\hline $8 / 28 / 98 \quad 14: 00$ & 2.27 & $8 / 29 / 9817: 00$ & 91.91 & & & & & & \\
\hline $8 / 28 / 9814: 30$ & 2.47 & $8 / 29 / 9818: 00$ & 91.91 & & & & & & \\
\hline $8 / 28 / 9815: 00$ & 2.49 & $8 / 29 / 9819: 00$ & 91.91 & & & & & & \\
\hline $8 / 28 / 9815: 30$ & 2.50 & $8 / 29 / 9820: 00$ & 91.91 & & & & & & \\
\hline $8 / 28 / 98$ 16:00 & 2.59 & $8 / 29 / 9821: 00$ & 91.92 & & & & & & \\
\hline $8 / 28 / 9816: 30$ & 2.51 & $8 / 29 / 9822: 00$ & 91.92 & & & & & & \\
\hline $8 / 28 / 98 \quad 17: 00$ & 2.55 & 8/29/98 23:00 & 91.92 & & & & & & \\
\hline $8 / 28 / 98 \quad 17: 30$ & 2.51 & $8 / 30 / 980: 00$ & 91.92 & & & & & & \\
\hline $8 / 28 / 98 \quad 18: 00$ & 2.57 & $8 / 30 / 981: 00$ & 91.93 & & & & & & \\
\hline $8 / 28 / 98 \quad 18: 30$ & 2.57 & $8 / 30 / 982: 00$ & 91.93 & & & & & & \\
\hline $8 / 28 / 98 \quad 19: 00$ & 2.58 & $8 / 30 / 983: 00$ & 91.94 & & & & & & \\
\hline $8 / 28 / 98 \quad 19: 30$ & 2.56 & $8 / 30 / 984: 00$ & 91.95 & & & & & & \\
\hline $8 / 28 / 9820: 00$ & 2.56 & $8 / 30 / 985: 00$ & 91.96 & & & & & & \\
\hline $8 / 28 / 9820: 30$ & 2.58 & $8 / 30 / 986: 00$ & 91.96 & & & & & & \\
\hline $8 / 28 / 9821: 00$ & 2.57 & $8 / 30 / 987: 00$ & 91.96 & & & & & & \\
\hline $8 / 28 / 9821: 30$ & 2.57 & $8 / 30 / 988: 00$ & 91.96 & & & & & & \\
\hline $8 / 28 / 9822: 00$ & 2.58 & $8 / 30 / 989: 00$ & 91.96 & & & & & & \\
\hline $8 / 28 / 9822: 30$ & 2.56 & $8 / 30 / 9810: 00$ & 91.96 & & & & & & \\
\hline $8 / 28 / 9823: 00$ & 2.57 & $8 / 30 / 9811: 00$ & 91.97 & & & & & & \\
\hline
\end{tabular}




\section{Appendix C - Specific Capacity Data and Calculations Phase II Single-Cell Specific Capacity (continued)}

\begin{tabular}{|c|c|c|c|c|c|c|c|c|c|}
\hline Date; Time & $\begin{array}{c}\text { Flow } \\
\text { (gpm) }\end{array}$ & Date; Time & $\begin{array}{c}\text { TGSC-1 } \\
\text { Elevation } \\
\text { (ft-msl) }\end{array}$ & $\begin{array}{c}\text { Average } \\
\text { Flow } \\
\text { (gpm) }\end{array}$ & \begin{tabular}{|c|} 
Average \\
TGSC-1 \\
Elevation \\
(ft-msl)
\end{tabular} & $\begin{array}{c}\text { Average } \\
\text { TGSC-1 } \\
\text { Drawdown } \\
\text { (ft) }\end{array}$ & $\begin{array}{c}\text { Specific } \\
\text { Capacity } \\
\text { (gpm/ft) }\end{array}$ & $\begin{array}{c}\text { Wetted } \\
\text { Screen } \\
\text { Length } \\
(\mathrm{ft})\end{array}$ & $\begin{array}{c}\text { Normalized } \\
\text { Specific } \\
\text { Capacity } \\
(\mathrm{gpm} / \mathrm{ft})\end{array}$ \\
\hline $8 / 28 / 9823: 30$ & 2.59 & $8 / 30 / 98 \quad 12: 00$ & 91.96 & & & & & & \\
\hline $8 / 29 / 980: 00$ & 2.56 & $8 / 30 / 98 \quad 13: 00$ & 91.95 & & & & & & \\
\hline $8 / 29 / 980: 30$ & 2.57 & $8 / 30 / 9814: 00$ & 91.95 & & & & & & \\
\hline $8 / 29 / 98$ 1:00 & 2.56 & $8 / 30 / 9815: 00$ & 91.94 & & & & & & \\
\hline $8 / 29 / 981: 30$ & 2.55 & $8 / 30 / 98 \quad 16: 00$ & 91.94 & & & & & & \\
\hline $8 / 29 / 982: 00$ & 2.53 & $8 / 30 / 9817: 00$ & 91.94 & & & & & & \\
\hline $8 / 29 / 982: 30$ & 2.52 & $8 / 30 / 9818: 00$ & 91.94 & & & & & & \\
\hline 8/29/98 3:00 & 2.55 & $8 / 30 / 98 \quad 19: 00$ & 91.94 & & & & & & \\
\hline $8 / 29 / 983: 30$ & 2.54 & $8 / 30 / 9820: 00$ & 91.94 & & & & & & \\
\hline $8 / 29 / 984: 00$ & 2.54 & $8 / 30 / 9821: 00$ & 91.94 & & & & & & \\
\hline $8 / 29 / 984: 30$ & 2.54 & $8 / 30 / 9822: 00$ & 91.94 & & & & & & \\
\hline $8 / 29 / 985: 00$ & 2.55 & $8 / 30 / 9823: 00$ & 91.94 & & & & & & \\
\hline $8 / 29 / 985: 30$ & 2.55 & $8 / 31 / 980: 00$ & 91.95 & & & & & & \\
\hline $8 / 29 / 986: 00$ & 2.56 & $8 / 31 / 981: 00$ & 91.95 & & & & & & \\
\hline $8 / 29 / 986: 30$ & 2.57 & $8 / 31 / 982: 00$ & 91.95 & & & & & & \\
\hline $8 / 29 / 987: 00$ & 2.56 & $8 / 31 / 983: 00$ & 91.95 & & & & & & \\
\hline $8 / 29 / 987: 30$ & 2.57 & $8 / 31 / 984: 00$ & 91.95 & & & & & & \\
\hline $8 / 29 / 988: 00$ & 2.57 & $8 / 31 / 985: 00$ & 91.96 & & & & & & \\
\hline $8 / 29 / 988: 30$ & 2.58 & $8 / 31 / 986: 00$ & 91.96 & & & & & & \\
\hline $8 / 29 / 989: 00$ & 2.57 & $8 / 31 / 987: 00$ & 91.96 & & & & & & \\
\hline $8 / 29 / 989: 30$ & 2.56 & $8 / 31 / 988: 00$ & 91.96 & & & & & & \\
\hline $8 / 29 / 98 \quad 10: 00$ & 2.54 & $8 / 31 / 989: 00$ & 91.97 & & & & & & \\
\hline $8 / 29 / 98 \quad 10: 30$ & 2.52 & $8 / 31 / 98 \quad 10: 00$ & 91.97 & & & & & & \\
\hline $8 / 29 / 9811: 00$ & 2.52 & $8 / 31 / 9811: 00$ & 91.97 & & & & & & \\
\hline $8 / 29 / 9811: 30$ & 2.50 & $8 / 31 / 9812: 00$ & 91.96 & & & & & & \\
\hline $8 / 29 / 98 \quad 12: 00$ & 2.49 & $8 / 31 / 9813: 00$ & 91.95 & & & & & & \\
\hline $8 / 29 / 98 \quad 12: 30$ & 2.45 & $8 / 31 / 9814: 00$ & 91.95 & & & & & & \\
\hline $8 / 29 / 98 \quad 13: 00$ & 2,44 & $8 / 31 / 98 \quad 15: 00$ & 91.94 & & & & & & \\
\hline $8 / 29 / 98 \quad 13: 30$ & 2.44 & $8 / 31 / 98 \quad 16: 00$ & 91.94 & & & & & & \\
\hline $8 / 29 / 9814: 00$ & 2.43 & $8 / 31 / 9817: 00$ & 91.94 & & & & & & \\
\hline $8 / 29 / 9814: 30$ & 2.43 & $8 / 31 / 9818: 00$ & 91.93 & & & & & & \\
\hline $8 / 29 / 98 \quad 15: 00$ & 2.26 & $8 / 31 / 9819: 00$ & 91.94 & & & & & & \\
\hline $8 / 29 / 98 \quad 15: 30$ & 2.36 & $8 / 31 / 9820: 00$ & 91.94 & & & & & & \\
\hline $8 / 29 / 98 \quad 16: 00$ & 2.49 & $8 / 31 / 9821: 00$ & 91.94 & & & & & & \\
\hline $8 / 29 / 98 \quad 16: 30$ & 2.47 & $8 / 31 / 9822: 00$ & 91.96 & & & & & & \\
\hline $8 / 29 / 98 \quad 17: 00$ & 2.47 & $8 / 31 / 9823: 00$ & 91.95 & & & & & & \\
\hline $8 / 29 / 98 \quad 17: 30$ & 2.46 & $9 / 1 / 980: 00$ & 91.95 & & & & & & \\
\hline $8 / 29 / 98 \quad 18: 00$ & 2.45 & $9 / 1 / 981: 00$ & 91.96 & & & & & & \\
\hline
\end{tabular}




\section{Appendix C - Specific Capacity Data and Calculations Phase II Single-Cell Specific Capacity (continued)}

\begin{tabular}{|c|c|c|c|c|c|c|c|c|c|}
\hline Date; Time & $\begin{array}{c}\text { Flow } \\
(\mathrm{gpm})\end{array}$ & Date; Time & $\begin{array}{c}\text { TGSC-1 } \\
\text { Elevation } \\
\text { (ft-msl) }\end{array}$ & $\begin{array}{l}\text { Average } \\
\text { Flow } \\
\text { (gpm) }\end{array}$ & $\begin{array}{c}\text { Average } \\
\text { TGSC-1 } \\
\text { Elevation } \\
(\mathrm{ft}-\mathrm{msl})\end{array}$ & $\begin{array}{c}\text { Average } \\
\text { TGSC-1 } \\
\text { Drawdown } \\
\text { (ft) }\end{array}$ & $\begin{array}{c}\text { Specific } \\
\text { Capacity } \\
(\mathrm{gpm} / \mathrm{ft})\end{array}$ & $\begin{array}{c}\text { Wetted } \\
\text { Screen } \\
\text { Length } \\
\text { (ft) }\end{array}$ & $\begin{array}{c}\text { Normalized } \\
\text { Specific } \\
\text { Capacity } \\
\text { (gpm/ft) }\end{array}$ \\
\hline $8 / 29 / 98 \quad 18: 30$ & 2.45 & 9/1/98 2:00 & 91.96 & & & & & & \\
\hline $8 / 29 / 9819: 00$ & 2.44 & $9 / 1 / 983: 00$ & 91.96 & & & & & & \\
\hline $8 / 29 / 9819: 30$ & 2.45 & $9 / 1 / 984: 00$ & 91.96 & & & & & & \\
\hline $8 / 29 / 9820: 00$ & $\overline{2.45}$ & 9/1/98 5:00 & 91.97 & & & & & & \\
\hline $8 / 29 / 9820: 30$ & 2.46 & $9 / 1 / 986: 00$ & 91.97 & & & & & & \\
\hline 8/29/98 21:00 & 2.46 & 9/1/98 7:00 & 91.97 & & & & & & \\
\hline $8 / 29 / 9821: 30$ & 2.48 & $9 / 1 / 988: 00$ & 91.97 & & & & & & \\
\hline $8 / 29 / 9822: 00$ & 2.46 & 9/1/98 9:00 & 91.97 & & & & & & \\
\hline $8 / 29 / 9822: 30$ & 2.47 & 9/1/98 $10: 00$ & 91.97 & & & & & & \\
\hline $8 / 29 / 9823: 00$ & 2.48 & 9/1/98 11:00 & 91.97 & & & & & & \\
\hline $8 / 29 / 9823: 30$ & 2.49 & $9 / 1 / 98 \quad 12: 00$ & 91.97 & & & & & & \\
\hline $8 / 30 / 980: 00$ & 2.49 & 9/1/98 13:00 & 91.97 & & . & & & & \\
\hline $8 / 30 / 980: 30$ & 2.49 & 9/1/98 14:00 & 91.96 & & & & & & \\
\hline $8 / 30 / 98$ 1:00 & 2.50 & 9/1/98.15:00 & 91.96 & & & & & & \\
\hline $8 / 30 / 98 \quad 1: 3.0$ & 2.50 & 9/1/98 16:00 & 91.96 & & & & & & \\
\hline $8 / 30 / 982: 00$ & 2.50 & 9/1/98 17:00 & 91.91 & & & & & & \\
\hline $8 / 30 / 982: 30$ & 2.50 & 9/1/98 18:00 & 91.91 & & & & & & \\
\hline 8/30/98 3:00 & 2.48 & 9/1/98 19:00 & 91.91 & & & & & & \\
\hline $8 / 30 / 98.3: 30$ & 2.46 & 9/1/98 20:00 & 91.91 & & & & & & \\
\hline $8 / 30 / 984: 00$ & 2.47 & 9/1/98 21:00 & 91.92 & & & & & & \\
\hline $8 / 30 / 984: 30$ & 2.48 & 9/1/98 22:00 & 91.92 & & & & & & \\
\hline $8 / 30 / 985: 00$ & 2.47 & 9/1/98 23:00 & 91.92 . & & & & & & \\
\hline $8 / 30 / 985: 30$ & 2.47 & 9/2/98 0:00 & 91.92 & & & & & & \\
\hline $8 / 30 / 986: 00$ & 2.48 & 9/2/98 1:00 & 91.93 & & & & & & \\
\hline $8 / 30 / 986: 30$ & 2.48 & $9 / 2 / 982: 00$ & 91.93 & & & & & & \\
\hline $8 / 30 / 987: 00$ & 2.49 & 9/2/98 3:00 & 91.93 & & & & & & \\
\hline $8 / 30 / 987: 30$ & 2.49 & $9 / 2 / 984: 00$ & 91.93 & & & & & & \\
\hline $8 / 30 / 988: 00$ & 2.50 & 9/2/98 5:00 & 91.95 & & & & & & \\
\hline $8 / 30 / 988: 30$ & 2.50 & 9/2/986:00 & 91.96 & & & & & & \\
\hline 8/30/98 9:00 & 2.50 & 9/2/98 7:00 & 91.97 & & & & & & \\
\hline $8 / 30 / 989: 30$ & 2.50 & 9/2/98 8:00 & 91.97 & & & & & & \\
\hline $8 / 30 / 98 \quad 10: 00$ & 2.48 & 9/2/98 9:00 & 91.97 & & & & & & \\
\hline $8 / 30 / 98 \quad 10: 30$ & 2.47 & $9 / 2 / 98 \quad 10: 00$ & 91.97 & & & & & & \\
\hline $8 / 30 / 98 \quad 11: 00$ & 2.45 & $9 / 2 / 9811: 00$ & 91.97 & & & & & & \\
\hline $8 / 30 / 9811: 30$ & 2.43 & $9 / 2 / 98 \quad 12: 00$ & 91.96 & & & & & & \\
\hline $8 / 30 / 98 \quad 12: 00$ & 2.41 & $9 / 2 / 9813: 00$ & 91.96 & & & & & & \\
\hline $8 / 30 / 98 \quad 12: 30$ & 2.40 & 9/2/98 14:00 & 91.96 & & & & & & \\
\hline $8 / 30 / 98 \quad 13: 00$ & 2.36 & 9/2/98 15:00 & 91.94 & & & & & & \\
\hline
\end{tabular}




\section{Appendix C - Specific Capacity Data and Calculations Phase II Single-Cell Specific Capacity (continued)}

\begin{tabular}{|c|c|c|c|c|c|c|c|c|c|}
\hline Date; Time & $\begin{array}{l}\text { Flow } \\
(\mathrm{gpm})\end{array}$ & Date; Time & $\begin{array}{c}\text { TGSC-1 } \\
\text { Elevation } \\
\text { (ft-msl) }\end{array}$ & $\begin{array}{l}\text { Average } \\
\text { Flow } \\
\text { (gpm) }\end{array}$ & \begin{tabular}{|c|} 
Average \\
TGSC-1 \\
Elevation \\
$(\mathrm{ft}-\mathrm{msl})$ \\
\end{tabular} & $\begin{array}{c}\text { Average } \\
\text { TGSC-1 } \\
\text { Drawdown } \\
\text { (ft) }\end{array}$ & $\begin{array}{c}\text { Specific } \\
\text { Capacity } \\
(\mathrm{gpm} / \mathrm{ft})\end{array}$ & $\begin{array}{c}\text { Wetted } \\
\text { Screen } \\
\text { Length } \\
(\mathrm{ft})\end{array}$ & $\begin{array}{c}\text { Normalized } \\
\text { Specific } \\
\text { Capacity } \\
(\mathrm{gpm} / \mathrm{ft})\end{array}$ \\
\hline $8 / 30 / 98 \quad 13: 30$ & 2.33 & $9 / 2 / 98 \quad 16: 00$ & 91.94 & & & & & & \\
\hline $8 / 30 / 98 \quad 14: 00$ & 2.31 & 9/2/98 17:00 & 91.94 & & & & & & \\
\hline $8 / 30 / 98 \quad 14: 30$ & 2.30 & 9/2/98 18:00 & 91.94 & & & & & & \\
\hline $8 / 30 / 98 \quad 15: 00$ & 2.28 & 9/2/98 19:00 & 91.93 & & & & & & \\
\hline $8 / 30 / 98 \quad 15: 30$ & 2.29 & 9/2/98 20:00 & 91.94 & & & & & & \\
\hline $8 / 30 / 98 \quad 16: 00$ & 2.28 & $9 / 2 / 9821: 00$ & 91.94 & & & & & & \\
\hline $8 / 30 / 98 \quad 16: 30$ & 2.27 & 9/2/98 22:00 & 91.94 & & & & & & \\
\hline $8 / 30 / 98 \quad 17: 00$ & 2.26 & $9 / 2 / 9823: 00$ & 91.95 & & & & & & \\
\hline $8 / 30 / 98 \quad 17: 30$ & 2.27 & 9/3/98 $0: 00$ & 91.95 & & & & & & \\
\hline $8 / 30 / 98 \quad 18: 00$ & 2.28 & $9 / 3 / 981: 00$ & 91.95 & & & & & & \\
\hline $8 / 30 / 9818: 30$ & 2.30 & $9 / 3 / 982: 00$ & 91.96 & & & & & & \\
\hline $8 / 30 / 98 \quad 19: 00$ & 2.30 & 9/3/983:00 & 91.95 & & & & & & \\
\hline $8 / 30 / 98 \quad 19: 30$ & 2.32 & 9/3/98 4:00 & 91.96 & & & & & & \\
\hline $8 / 30 / 9820: 00$ & 2.33 & 9/3/985:00 & 91.96 & & & & & & \\
\hline $8 / 30 / 98 \quad 20: 30$ & 2.32 & 9/3/986:00 & 91.97 & & & & & & \\
\hline $8 / 30 / 98 \quad 21: 00$ & 2.32 & Average & 91.95 & & & & & & \\
\hline $8 / 30 / 9821: 30$ & 2.32 & & & & & & & & \\
\hline $8 / 30 / 9822: 00$ & 2.33 & & & & & & & & \\
\hline $8 / 30 / 9822: 30$ & 2.34 & & & & & & & & \\
\hline $8 / 30 / 9823: 00$ & 2.34 & & & & & & & & \\
\hline $8 / 30 / 9823: 30$ & 2.35 & & & & & & & & \\
\hline $8 / 31 / 980: 00$ & 2.36 & & & & & & & & \\
\hline $8 / 31 / 980: 30$ & 2.37 & & & & & & & & \\
\hline $8 / 31 / 981: 00$ & 2.38 & & & & & & & & \\
\hline $8 / 31 / 981: 30$ & 2.38 & & & & & & & & \\
\hline $8 / 31 / 982: 00$ & 2.39 & & & & & & & & \\
\hline $8 / 31 / 982: 30$ & 2.40 & & & & & & & & \\
\hline $8 / 31 / 983: 00$ & 2.40 & & & & & & & & \\
\hline $8 / 31 / 983: 30$ & 2.41 & & & & & & & & \\
\hline $8 / 31 / 984: 00$ & 2.41 & & & & & & & & \\
\hline $8 / 31 / 984: 30$ & 2.42 & & & & & & & & \\
\hline $8 / 31 / 985: 00$ & 2.43 & & & & & & & & \\
\hline $8 / 31 / 985: 30$ & 2.43 & & & & & & & & \\
\hline $8 / 31 / 986: 00$ & 2.43 & & & & & & & & \\
\hline $8 / 31 / 986: 30$ & 2.44 & & & & & & & & \\
\hline $8 / 31 / 987: 00$ & 2.46 & & & & & & & & \\
\hline $8 / 31 / 987: 30$ & 2.46 & & & & & & & & \\
\hline $8 / 31 / 988: 00$ & 2.47 & & & & & & & & \\
\hline
\end{tabular}




\section{Appendix C - Specific Capacity Data and Calculations \\ Phase II Single-Cell Specific Capacity (continued)}

\begin{tabular}{|c|c|c|c|c|c|c|c|c|c|}
\hline Date; Time & $\begin{array}{l}\text { Flow } \\
(\mathrm{gpm})\end{array}$ & Date; Time & $\begin{array}{l}\text { TGSC-1 } \\
\text { Elevation } \\
\text { (ft-msl) }\end{array}$ & $\begin{array}{l}\text { Average } \\
\text { Flow } \\
\text { (gpm) }\end{array}$ & \begin{tabular}{|c|} 
Average \\
TGSC-1 \\
Elevation \\
$(\mathrm{ft}-\mathrm{ms})$
\end{tabular} & $\begin{array}{c}\text { Average } \\
\text { TGSC-1 } \\
\text { Drawdown } \\
\text { (ft) }\end{array}$ & $\begin{array}{l}\text { Specific } \\
\text { Capacity } \\
\text { (gpm/ft) }\end{array}$ & $\begin{array}{c}\text { Wetted } \\
\text { Screen } \\
\text { Length } \\
\text { (ft) }\end{array}$ & $\begin{array}{l}\text { Normalized } \\
\text { Specific } \\
\text { Capacity } \\
\text { (gpm/ft) }\end{array}$ \\
\hline $8 / 31 / 988: 30$ & 2.50 & & & & & & & & \\
\hline $8 / 31 / 989: 00$ & 2.49 & & & & & & & & \\
\hline $8 / 31 / 989: 30$ & 2.48 & & & & & & & & \\
\hline $8 / 31 / 9810: 00$ & 2.47 & & & & & & & & \\
\hline $8 / 31 / 9810: 30$ & 2.46 & & & & & & & & \\
\hline $8 / 31 / 9811: 00$ & 2.44 & & & & & & & & \\
\hline $8 / 31 / 98 \quad 11: 30$ & 2.41 & & & & & & & & \\
\hline $8 / 31 / 9812: 00$ & 2.39 & & & & & & & & \\
\hline $8 / 31 / 98 \quad 12: 30$ & 2.36 & & & & & & & & \\
\hline $8 / 31 / 9813: 00$ & 2.33 & & & & & & & & \\
\hline $8 / 31 / 9813: 30$ & 2.31 & & & & & & & & \\
\hline $8 / 31 / 9814: 00$ & 2.30 & & & & & & & & \\
\hline $8 / 31 / 9814: 30$ & 2.29 & & & & & & & & \\
\hline $8 / 31 / 98 \quad 15: 00$ & 2.27 & & & & & & & & \\
\hline $8 / 31 / 9815: 30$ & 2.25 & & & & & & & & \\
\hline $8 / 31 / 98 \quad 16: 00$ & 2.25 & & & & & & & & \\
\hline $8 / 31 / 98 \quad 16: 30$ & 2.25 & & & & & & & & \\
\hline $8 / 31 / 9817: 00$ & 2.24 & & & & & & & & \\
\hline $8 / 31 / 98 \quad 17: 30$ & 2.24 & & & & & & & & \\
\hline $8 / 31 / 9818: 00$ & 2.25 & & & & & & & & \\
\hline $8 / 31 / 9818: 30$ & 2.27 & & & & & & & & \\
\hline $8 / 31 / 98 \quad 19: 00$ & 2.28 & & & & & & & & \\
\hline $8 / 31 / 9819: 30$ & 2.28 & & & & & & & & \\
\hline $8 / 31 / 9820: 00$ & 2.28 & & & & & & & & \\
\hline $8 / 31 / 9820: 30$ & 2.29 & & & & & & & & \\
\hline $8 / 31 / 9821: 00$ & 2.25 & & & & & & & & \\
\hline $8 / 31 / 9821: 30$ & 2.31 & & & & & & & & \\
\hline $8 / 31 / 9822: 00$ & 2.34 & & & & & & & & \\
\hline $8 / 31 / 98222: 30$ & 2.36 & & & & & & & & \\
\hline $8 / 31 / 9823: 00$ & 2.39 & & & & & & & & \\
\hline $8 / 31 / 9823: 30$ & 2.39 & & & & & & & & \\
\hline $9 / 1 / 980: 00$ & 2.40 & & & & & & & & \\
\hline $9 / 1 / 980: 30$ & 2.41 & & & & & & & & \\
\hline 9/1/98 1:00 & 2.42 & & & & & & & & \\
\hline 9/1/98 1:30 & 2.42 & & & & & & & & \\
\hline 9/1/98 2:00 & 2.43 & & & & & & & & \\
\hline $9 / 1 / 982: 30$ & 2.44 & & & & & & & & \\
\hline $9 / 1 / 983: 00$ & 2.45 & & & & & & & & \\
\hline
\end{tabular}




\section{Appendix C-Specific Capacity Data and Calculations Phase II Single-Cell Specific Capacity (continued)}

\begin{tabular}{|c|c|c|c|c|c|c|c|c|c|}
\hline Date; Time & $\begin{array}{c}\text { Flow } \\
(\mathrm{gpm})\end{array}$ & Date; Time & $\begin{array}{c}\text { TGSC-1 } \\
\text { Elevation } \\
\text { (ft-msl) } \\
\end{array}$ & $\begin{array}{c}\text { Average } \\
\text { Flow } \\
\text { (gpm) } \\
\end{array}$ & \begin{tabular}{|c|} 
Average \\
TGSC-1 \\
Elevation \\
$(\mathrm{ft}-\mathrm{msl})$ \\
\end{tabular} & $\begin{array}{c}\text { Average } \\
\text { TGSC-1 } \\
\text { Drawdown } \\
\text { (ft) }\end{array}$ & $\begin{array}{l}\text { Specific } \\
\text { Capacity } \\
\text { (gpm/ft) }\end{array}$ & $\begin{array}{c}\text { Wetted } \\
\text { Screen } \\
\text { Length } \\
(\mathrm{ft}) \\
\end{array}$ & $\begin{array}{c}\text { Normalized } \\
\text { Specific } \\
\text { Capacity } \\
(\mathrm{gpm} / \mathrm{ft})\end{array}$ \\
\hline $9 / 1 / 983: 30$ & 2.45 & & & & & & & & \\
\hline $9 / 1 / 984: 00$ & 2.45 & & & & & & & & \\
\hline $9 / 1 / 984: 30$ & 2.46 & & & & & & & & \\
\hline $9 / 1 / 985: 00$ & 2.46 & & & & & & & & \\
\hline $9 / 1 / 985: 30$ & 2.46 & & & & & & & & \\
\hline $9 / 1 / 986: 00$ & 2.46 & & & & & & & & \\
\hline $9 / 1 / 986: 30$ & 2.47 & & & & & & & & \\
\hline $9 / 1 / 987: 00$ & 2.49 & & & & & & & & \\
\hline $9 / 1 / 987: 30$ & 2.48 & & & & & & & & \\
\hline $9 / 1 / 988: 00$ & 2.48 & & & & & & & & \\
\hline $9 / 1 / 988: 30$ & 2.47 & & & & & & & & \\
\hline $9 / 1 / 989: 00$ & 2.49 & & & & & & & & \\
\hline $9 / 1 / 989: 30$ & 2.50 & & & & & & & & \\
\hline 9/1/98 10:00 & 2.48 & & & & & & & & \\
\hline $9 / 1 / 98 \quad 10: 30$ & 2.47 & & & & & & & & \\
\hline $9 / 1 / 9811: 00$ & 2.46 & & & & & & & & \\
\hline $9 / 1 / 9811: 30$ & 2.45 & & & & & & & & \\
\hline 9/1/98 12:00 & 2.46 & & & & & & & & \\
\hline $9 / 1 / 98 \quad 12: 30$ & 2.44 & & & & & & & & \\
\hline $9 / 1 / 9813: 00$ & 2.42 & & & & & & & & \\
\hline $9 / 1 / 9813: 30$ & 2.41 & & & & & & & & \\
\hline $9 / 1 / 98 \quad 14: 00$ & 2.39 & & & & & & & & \\
\hline $9 / 1 / 9814: 30$ & 2.38 & & & & & & & & \\
\hline 9/1/98 15:00 & 2.36 & & & & & & & & \\
\hline $9 / 1 / 98$ 15:30 & 2.34 & & & & & & & & \\
\hline $9 / 1 / 98 \quad 16: 00$ & 2.33 & & & & & & & & \\
\hline $9 / 1 / 98 \quad 16: 30$ & 2.41 & & & & & & & & \\
\hline $9 / 1 / 98 \quad 17: 00$ & 2.40 & & & & & & & & \\
\hline $9 / 1 / 98 \quad 17: 30$ & 2.40 & & & & & & & & \\
\hline $9 / 1 / 98 \quad 18: 00$ & 2.40 & & & & & & & & \\
\hline $9 / 1 / 9818: 30$ & 2.40 & & & & & & & & \\
\hline $9 / 1 / 98 \quad 19: 00$ & 2.41 & & & & & & & & \\
\hline 9/1/98 19:30 & 2.42 & & & & & & & & \\
\hline $9 / 1 / 9820: 00$ & 2.43 & & & & & & & & \\
\hline 9/1/98 20:30 & 2.43 & & & & & & & & \\
\hline $9 / 1 / 9821: 00$ & 2.44 & & & & & & & & \\
\hline $9 / 1 / 9821: 30$ & 2.44 & & & & & & & & \\
\hline $9 / 1 / 9822: 00$ & 2.45 & & & & & & & & \\
\hline
\end{tabular}




\section{Appendix C - Specific Capacity Data and Calculations Phase II Single-Cell Specific Capacity (continued)}

\begin{tabular}{|c|c|c|c|c|c|c|c|c|c|}
\hline Date; Time & $\begin{array}{l}\text { Flow } \\
(\mathrm{gpm})\end{array}$ & Date; Time & $\begin{array}{c}\text { TGSC-1 } \\
\text { Elevation } \\
\text { (ft-msl) }\end{array}$ & $\begin{array}{c}\text { Average } \\
\text { Flow } \\
\text { (gpm) }\end{array}$ & $\begin{array}{c}\text { Average } \\
\text { TGSC-1 } \\
\text { Elevation } \\
(\mathrm{ft}-\mathrm{msl})\end{array}$ & $\begin{array}{c}\text { Average } \\
\text { TGSC-1 } \\
\text { Drawdown } \\
\text { (ft) }\end{array}$ & $\begin{array}{l}\text { Specific } \\
\text { Capacity } \\
(\mathrm{gpm} / \mathrm{ft})\end{array}$ & $\begin{array}{c}\text { Wetted } \\
\text { Screen } \\
\text { Length } \\
\text { (ft) }\end{array}$ & $\begin{array}{c}\text { Normalized } \\
\text { Specific } \\
\text { Capacity } \\
(\mathrm{gpm} / \mathrm{ft})\end{array}$ \\
\hline $9 / 1 / 9822: 30$ & 2.45 & & & & & & & & \\
\hline $9 / 1 / 9823: 00$ & 2.47 & & & & & & & & \\
\hline $9 / 1 / 9823: 30$ & 2.47 & & & & & & & & \\
\hline $9 / 2 / 980: 00$ & 2.48 & & & & & & & & \\
\hline $9 / 2 / 980: 30$ & 2.47 & & & & & & & & \\
\hline $9 / 2 / 981: 00$ & 2.48 & & & & & & & & \\
\hline $9 / 2 / 981: 30$ & 2.49 & & & & & & & & \\
\hline $9 / 2 / 982: 00$ & 2.48 & & & & & & & & \\
\hline $9 / 2 / 982: 30$ & 2.49 & & & & & & & & \\
\hline $9 / 2 / 983: 00$ & 2.49 & & & & & & & & \\
\hline $9 / 2 / 983: 30$ & 2.49 & & & & & & & & \\
\hline $9 / 2 / 984: 00$ & 2.49 & & & & & & & & \\
\hline $9 / 2 / 984: 30$ & 2.47 & & & & & & & & \\
\hline $9 / 2 / 985: 00$ & 2.45 & & & & & & & & \\
\hline $9 / 2 / 985: 30$ & 2.45 & & & & & & & & \\
\hline $9 / 2 / 986: 00$ & 2.45 & & & & & & & & \\
\hline $9 / 2 / 986: 30$ & 2.46 & & & & & & & & \\
\hline $9 / 2 / 987: 00$ & 2.46 & & & & & & & & \\
\hline $9 / 2 / 987: 30$ & 2.46 & & & & & & & & \\
\hline 9/2/98 8:00 & 2.47 & & & & & & & & \\
\hline $9 / 2 / 988: 30$ & 2.47 & & & & & & & & \\
\hline 9/2/98 9:00 & 2.46 & & & & & & & & \\
\hline $9 / 2 / 989: 30$ & 2.46 & & & & & & & & \\
\hline $9 / 2 / 98 \quad 10: 00$ & 2.46 & & & & & & & & \\
\hline $9 / 2 / 98 \quad 10: 30$ & 2.45 & & & & & & & & \\
\hline $9 / 2 / 9811: 00$ & 2.44 & & & & & & & & \\
\hline $9 / 2 / 9811: 30$ & 2.42 & & & & & & & & \\
\hline $9 / 2 / 98 \quad 12: 00$ & 2.41 & & & & & & & & \\
\hline $9 / 2 / 98 \quad 12: 30$ & 2.39 & & & & & & & & \\
\hline $9 / 2 / 9813: 00$ & 2.37 & & & & & & & & \\
\hline $9 / 2 / 98 \quad 13: 30$ & 2.35 & & & & & & & & \\
\hline $9 / 2 / 98 \quad 14: 00$ & 2.34 & & & & & & & & \\
\hline $9 / 2 / 98 \quad 14: 30$ & 2.33 & & & & & & & & \\
\hline $9 / 2 / 98 \quad 15: 00$ & 2.29 & & & . & & & & & \\
\hline $9 / 2 / 98 \quad 15: 30$ & 2.28 & & & & & & & & \\
\hline $9 / 2 / 98 \quad 16: 00$ & 2.25 & & & & & & & & \\
\hline $9 / 2 / 98 \quad 16: 30$ & 2.25 & & & & & & & & \\
\hline $9 / 2 / 98 \quad 17: 00$ & 2.23 & & & & & & & & \\
\hline
\end{tabular}




\section{Appendix C - Specific Capacity Data and Calculations \\ Phase II Single-Cell Specific Capacity (continued)}

\begin{tabular}{|c|c|c|c|c|c|c|c|c|c|}
\hline Date; Time & $\begin{array}{l}\text { Flow } \\
(\mathrm{gpm})\end{array}$ & Date; Time & $\begin{array}{c}\text { TGSC-1 } \\
\text { Elevation } \\
\text { (ft-msl) }\end{array}$ & $\begin{array}{c}\text { Average } \\
\text { Flow } \\
\text { (gpm) }\end{array}$ & \begin{tabular}{|c|} 
Average \\
TGSC-1 \\
Elevation \\
(ft-msl)
\end{tabular} & $\begin{array}{c}\text { Average } \\
\text { TGSC-1 } \\
\text { Drawdown } \\
\text { (ft) }\end{array}$ & $\begin{array}{l}\text { Specific } \\
\text { Capacity } \\
\text { (gpm/ft) }\end{array}$ & $\begin{array}{c}\text { Wetted } \\
\text { Screen } \\
\text { Length } \\
\text { (ft) }\end{array}$ & $\begin{array}{l}\text { Normalized } \\
\text { Specific } \\
\text { Capacity } \\
\text { (gpm/ft) }\end{array}$ \\
\hline $9 / 2 / 98 \quad 17: 30$ & 2.24 & & & & & & & & \\
\hline $9 / 2 / 98 \quad 18: 00$ & 2.24 & & & & & & & & \\
\hline $9 / 2 / 98 \quad 18: 30$ & 2.24 & & & & & & & & \\
\hline 9/2/98 19:00 & 2.24 & & & & & & & & \\
\hline $9 / 2 / 98 \quad 19: 30$ & 2.25 & & & & & & & & \\
\hline $9 / 2 / 9820: 00$ & 2.26 & & & & & & & & \\
\hline $9 / 2 / 9820: 30$ & 2.26 & & & & & & & & \\
\hline 9/2/98 21:00 & 2.27 & & & & & & & & \\
\hline $9 / 2 / 9821: 30$ & 2.27 & & & & & & & & \\
\hline $9 / 2 / 9822: 00$ & 2.29 & & & & & & & & \\
\hline $9 / 2 / 9822: 30$ & 2.29 & & & & & & & & \\
\hline 9/2/98 23:00 & 2.28 & & & & & & & & \\
\hline $9 / 2 / 9823: 30$ & 2.30 & & & & & & & & \\
\hline $9 / 3 / 980: 00$ & 2.30 & & & & & & & & \\
\hline $9 / 3 / 980: 30$ & 2.30 & & & & & & & & \\
\hline 9/3/98 1:00 & 2.31 & & & & & & & & \\
\hline 9/3/98 1:30 & 2.33 & & & & & & & & \\
\hline 9/3/98 2:00 & 2.33 & & & & & & & & \\
\hline $9 / 3 / 982: 30$ & 2.33 & & & & & & & & \\
\hline 9/3/98 3:00 & 2.33 & & & & & & & & \\
\hline 9/3/98 3:30 & 2.35 & & & & & & & & \\
\hline 9/3/98 4:00 & 2.35 & & & & & & & & \\
\hline 9/3/98 4:30 & 2.34 & & & & & & & & \\
\hline 9/3/98 5:00 & 2.33 & & & & & & & & \\
\hline 9/3/985:30 & 2.33 & & & & & & & & \\
\hline 9/3/98 6:00 & 2.37 & & & & & & & & \\
\hline Average & 2.44 & & & & & & & & \\
\hline
\end{tabular}




\section{Appendix C - Specific Capacity Data and Calculations Phase II Minimum Flushing Velocity Specific Capacity}

\begin{tabular}{|c|c|c|c|c|c|c|c|c|c|}
\hline Date; Time & $\begin{array}{c}\text { Flow } \\
(\mathrm{gpm})\end{array}$ & Date; Time & $\begin{array}{c}\text { TGSC-1 } \\
\text { Elevation } \\
\text { (ft-msl) }\end{array}$ & $\begin{array}{l}\text { Average } \\
\text { Flow } \\
\text { (gpm) }\end{array}$ & $\begin{array}{c}\text { Average } \\
\text { TGSC-1 } \\
\text { Elevation } \\
\text { (ft-msl) }\end{array}$ & $\begin{array}{c}\text { Average } \\
\text { TGSC-1 } \\
\text { Drawdown } \\
\text { (ft) }\end{array}$ & $\begin{array}{r}\text { Specific } \\
\text { Capacity } \\
(\mathrm{gpm} / \mathrm{ft})\end{array}$ & $\begin{array}{c}\text { Wetted } \\
\text { Screen } \\
\text { Length } \\
(\mathrm{ft})\end{array}$ & $\begin{array}{c}\text { Normalized } \\
\text { Specific } \\
\text { Capacity } \\
(\mathrm{gpm} / \mathrm{ft})\end{array}$ \\
\hline $4 / 27 / 997: 17$ & 0.0 & $4 / 27 / 997: 15$ & 92.33 & & & & & & \\
\hline $4 / 27 / 99$ 8:29 & 4.4 & $4 / 27 / 998: 30$ & 89.61 & 4.36 & 89.70 & 2.63 & 1.66 & 12.80 & 1.81 \\
\hline $4 / 27 / 998: 41$ & 4.5 & $4 / 27 / 998: 45$ & 89.65 & & & & & & \\
\hline $4 / 27 / 998: 53$ & 4.3 & $4 / 27 / 999: 00$ & 89.72 & & & & & & \\
\hline $4 / 27 / 999: 05$ & 4.3 & $4 / 27 / 999: 15$ & 89.75 & & & & . & & \\
\hline $4 / 27 / 999: 17$ & 4.7 & $4 / 27 / 999: 30$ & 89.83 & & & & & & \\
\hline $4 / 27 / 999: 29$ & 4.3 & $4 / 27 / 999: 45$ & 89.87 & & & & & & \\
\hline $4 / 27 / 999: 41$ & 5.0 & $4 / 27 / 9910: 00$ & 89.87 & & & & & & \\
\hline $4 / 27 / 999: 53$ & 4.1 & $4 / 27 / 9910: 15$ & 89.82 & & & & & & \\
\hline $4 / 27 / 9910: 05$ & 3.9 & $4 / 27 / 99 \quad 10: 30$ & 89.63 & & & & & & \\
\hline $4 / 27 / 99 \quad 10: 17$ & 3.9 & $4 / 27 / 99 \quad 10: 45$ & 89.44 & & & & & & \\
\hline $4 / 27 / 99 \quad 10: 29$ & 5.1 & $4 / 27 / 9911: 00$ & 89.62 & & & & & & \\
\hline $4 / 27 / 99 \quad 10: 41$ & 4.5 & $4 / 27 / 9911: 15$ & 89.93 & & & & & & \\
\hline $4 / 27 / 9910: 53$ & 4.4 & $4 / 27 / 9911: 30$ & 89.51 & & & & & & \\
\hline $4 / 27 / 9911: 05$ & 4.2 & $4 / 27 / 9911: 45$ & 89.74 & & & & & & \\
\hline $4 / 27 / 9911: 17$ & 3.9 & $4 / 27 / 9912: 00$ & 89.51 & & & & & & \\
\hline $4 / 27 / 9911: 29$ & 4.5 & $4 / 27 / 9912: 15$ & 89.73 & & & & & & \\
\hline $4 / 27 / 9911: 41$ & 4.2 & average & 89.70 & & & & & & \\
\hline $4 / 27 / 9911: 53$ & 5.2 & & & & & & & & \\
\hline $4 / 27 / 9912: 05$ & 4.2 & & & & - & & & & \\
\hline $4 / 27 / 9912: 17$ & 4.0 & & & & & & & & \\
\hline $4 / 27 / 99.12: 29$ & 4.0 & & & & & & & & \\
\hline average & 4.36 & & & & & & & & \\
\hline
\end{tabular}




\section{Left Blank Intentionally}


APPENDIX D

DISSOLVED GAS AND GAS ANALYTICAL DATA AND CALCULATIONS:

APPENDIX D-1, ANALYTICAL DATA

APPENDIX D-2, AVERAGED ANALYTICAL DATA

APPENDIX D-3, CALCULATED DISSOLVED GAS SATURATION

CONCENTRATION IN EQUILIBRIUM WITH

ATMOSPHERIC AIR

APPENDIX D-4, CALCULATED NORMALIZED EQUILIBRIUM GASPHASE CONCENTRATION IN EQUILIBRIUM WITH THE SIPHON DISCHARGE POINT AVERAGE DISSOLVED GAS CONCENTRATION 
Microseeps AM-19 Bubble Strip Method for Dissolved Gases

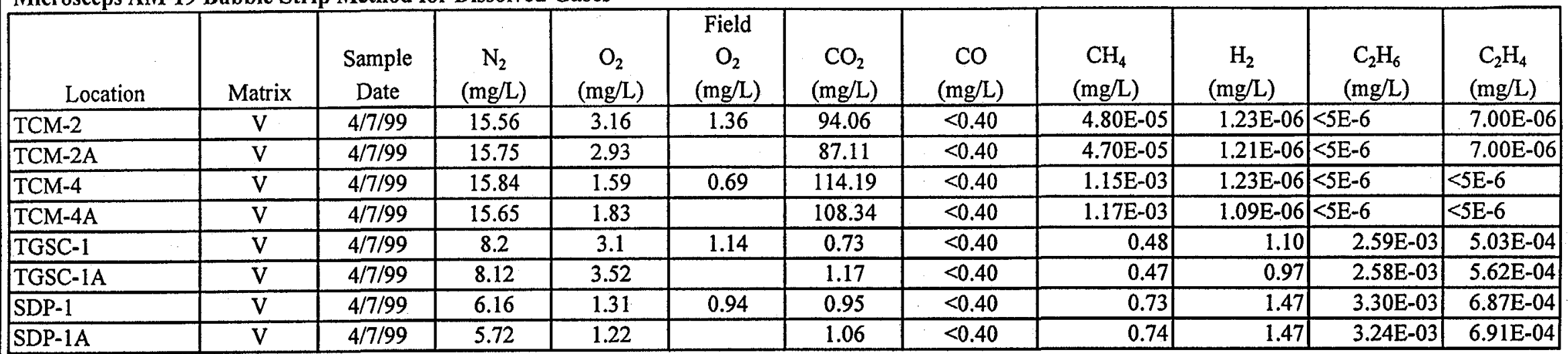

芯

\begin{tabular}{|l|l|l|l|l|l|l|l|l|l|}
\hline Detection Limits & 0.40 & 0.15 & 0.01 & 0.60 & 0.40 & $1.50 \mathrm{E}-05$ & $6.05 \mathrm{E}-08$ & $5.00 \mathrm{E}-06$ & $5.00 \mathrm{E}-06$ \\
\hline
\end{tabular}

Microseeps AM-19. Bubble Strip Method for Dissolved Gases

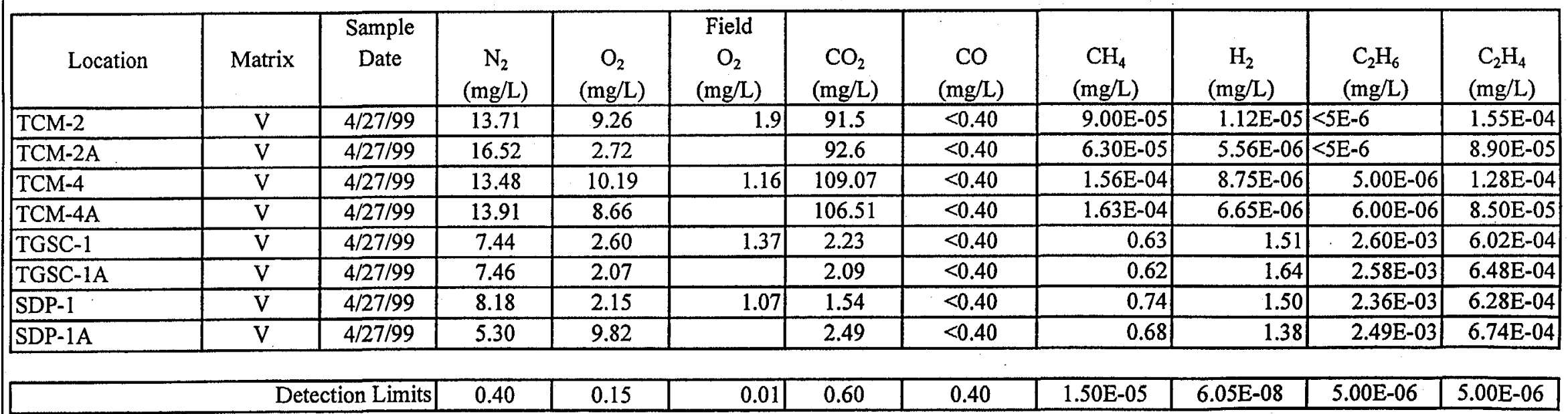


Appendix D-1, Analytical Data (continued)

Microseeps AM-19 Gas Analysis

\begin{tabular}{|c|c|c|c|c|c|c|c|c|c|c|}
\hline Location & Matrix & $\begin{array}{c}\text { Sample } \\
\text { Date }\end{array}$ & $\begin{array}{c}\mathrm{N}_{2} \\
(\% / \mathrm{V})\end{array}$ & $\begin{array}{c}\mathrm{O}_{2} \\
(\% / \mathrm{V}) \\
\end{array}$ & $\begin{array}{c}\mathrm{CO}_{2} \\
(\% / \mathrm{V}) \\
\end{array}$ & $\begin{array}{c}\mathrm{CO} \\
(\% / \mathrm{V})\end{array}$ & $\begin{array}{c}\mathrm{CH}_{4} \\
(\% / \mathrm{V}) \\
\end{array}$ & $\begin{array}{c}\mathrm{H}_{2} \\
(\% / \mathrm{V})\end{array}$ & $\begin{array}{l}\mathrm{C}_{2} \mathrm{H}_{6} \\
(\% / \mathrm{V}) \\
\end{array}$ & $\begin{array}{l}\mathrm{C}_{2} \mathrm{H}_{4} \\
(\% / \mathrm{V}) \\
\end{array}$ \\
\hline TGSC-1-AC-1-1B & $\mathrm{V}$ & $8 / 24 / 98$ & 46.42 & 4.96 & $<0.01$ & $<0.01$ & 1.95 & 41.28 & $4.14 \mathrm{E}-03$ & $6.08 \mathrm{E}-04$ \\
\hline TGSC-1-AC-2-1B & $\mathrm{V}$ & $8 / 24 / 98$ & 46.07 & 4.79 & $<0.01$ & $<0.01$ & 1.99 & 40.70 & $4.21 \mathrm{E}-03$ & $6.18 \mathrm{E}-04$ \\
\hline \multicolumn{3}{|c|}{ Detection Limits } & 0.04 & 0.02 & 0.02 & 0.02 & $4.00 \mathrm{E}-06$ & $2.00 \mathrm{E}-06$ & $1.00 \mathrm{E}-06$ & $1.00 \mathrm{E}-06$ \\
\hline \multicolumn{11}{|c|}{ Microseeps AM-19 Gas Analysis } \\
\hline Location & Matrix & $\begin{array}{c}\text { Sample } \\
\text { Date }\end{array}$ & $\begin{array}{c}\mathrm{N}_{2} \\
(\% / \mathrm{V})\end{array}$ & $\begin{array}{c}\mathrm{O}_{2} \\
(\% / \mathrm{V})\end{array}$ & $\begin{array}{c}\mathrm{CO}_{2} \\
(\% / \mathrm{V})\end{array}$ & $\begin{array}{c}\mathrm{CO} \\
(\% / \mathrm{V})\end{array}$ & $\begin{array}{c}\mathrm{CH}_{4} \\
(\% / \mathrm{V}) \\
\end{array}$ & $\begin{array}{c}\mathrm{H}_{2} \\
(\% / \mathrm{V}) \\
\end{array}$ & $\begin{array}{c}\mathrm{C}_{2} \mathrm{H}_{6} \\
(\% / \mathrm{V}) \\
\end{array}$ & $\begin{array}{c}\mathrm{C}_{2} \mathrm{H}_{4} \\
(\% / \mathrm{V})\end{array}$ \\
\hline SC-1 & $\mathrm{V}$ & $4 / 27 / 99$ & 78.71 & 23.46 & 0.07 & $<0.02$ & $1.48 \mathrm{E}-03$ & 0.68 & $4.00 \mathrm{E}-06$ & $2.00 \mathrm{E}-06$ \\
\hline SC-1A & $\mathrm{V}$ & $4 / 27 / 99$ & 73.18 & 21.60 & 0.06 & $<0.02$ & $1.76 \mathrm{E}-01$ & 10.96 & $2.00 \mathrm{E}-04$ & $2.70 \mathrm{E}-05$ \\
\hline \multicolumn{3}{|c|}{ Detection Limits } & 0.04 & 0.02 & 0.02 & 0.02 & $4.00 \mathrm{E}-06$ & $2.00 \mathrm{E}-06$ & $1.00 \mathrm{E}-06$ & $1.00 \mathrm{E}-06$ \\
\hline $\begin{array}{l}\mathrm{W}=\text { Water } \\
\mathrm{V}=\text { Vapor }\end{array}$ & & & & & & & & & & \\
\hline
\end{tabular}


Microseeps AM-19 Bubble Strip Method for Dissolved Gases

\begin{tabular}{|c|c|c|c|c|c|c|c|c|c|c|c|}
\hline Location & Matrix & $\begin{array}{l}\text { Sample } \\
\text { Date }\end{array}$ & $\begin{array}{c}\mathrm{N}_{2} \\
(\mathrm{mg} / \mathrm{L})\end{array}$ & $\begin{array}{c}\mathrm{O}_{2} \\
(\mathrm{mg} / \mathrm{L})\end{array}$ & $\begin{array}{c}\text { Field } \\
\mathrm{O}_{2} \\
(\mathrm{mg} / \mathrm{L}) \\
\end{array}$ & $\begin{array}{c}\mathrm{CO}_{2} \\
(\mathrm{mg} / \mathrm{L})\end{array}$ & $\begin{array}{c}\mathrm{CO} \\
(\mathrm{mg} / \mathrm{L}) \\
\end{array}$ & $\begin{array}{c}\mathrm{CH}_{4} \\
(\mathrm{mg} / \mathrm{L}) \\
\end{array}$ & $\begin{array}{c}\mathrm{H}_{2} \\
(\mathrm{mg} / \mathrm{L}) \\
\end{array}$ & $\begin{array}{c}\mathrm{C}_{2} \mathrm{H}_{6} \\
(\mathrm{mg} / \mathrm{L}) \\
\end{array}$ & $\begin{array}{c}\mathrm{C}_{2} \mathrm{H}_{4} \\
(\mathrm{mg} / \mathrm{L}) \\
\end{array}$ \\
\hline TCM-2 & $\mathrm{V}$ & $4 / 7 / 99$ & 15.56 & 3.16 & 1.36 & 94.06 & $<0.40$ & $4.80 \mathrm{E}-05$ & $1.23 \mathrm{E}-06$ & $<5 \mathrm{E}-6$ & $7.00 \mathrm{E}-06$ \\
\hline TCM-2A & $\mathrm{V}$ & $4 / 7 / 99$ & 15.75 & 2.93 & & 87.11 & $<0.40$ & $4.70 \mathrm{E}-05$ & $1.21 \mathrm{E}-06$ & $<5 \mathrm{E}-6$ & $7.00 \mathrm{E}-06$ \\
\hline TCM-2 & $\mathrm{V}$ & $4 / 27 / 99$ & 13.71 & 9.26 & 1.90 & 91.50 & $<0.40$ & $9.00 \mathrm{E}-05$ & $1.12 \mathrm{E}-05$ & $<5 \mathrm{E}-6$ & $1.55 \mathrm{E}-04$ \\
\hline TCM-2A & $\mathrm{V}$ & $4 / 27 / 99$ & 16.52 & 2.72 & & 92.60 & $<0.40$ & $6.30 \mathrm{E}-05$ & $5.56 \mathrm{E}-06$ & $<5 \mathrm{E}-6$ & $8.90 \mathrm{E}-05$ \\
\hline & & Average & 15.39 & 4.52 & 1.63 & 91.32 & $<0.40$ & $6.20 \mathrm{E}-05$ & $4.81 \mathrm{E}-06$ & $<5 \mathrm{E}-6$ & $6.45 \mathrm{E}-05$ \\
\hline TCM-4 & $\mathrm{V}$ & $4 / 7 / 99$ & 15.84 & 1.59 & 0.69 & 114.19 & $<0.40$ & $1.15 \mathrm{E}-03$ & $1.23 \mathrm{E}-06$ & $<5 \mathrm{E}-6$ & $<5 \mathrm{E}-6$ \\
\hline TCM-4A & $\mathrm{V}$ & $4 / 7 / 99$ & 15.65 & 1.83 & & 108.34 & $<0.40$ & $1.17 \mathrm{E}-03$ & $1.09 \mathrm{E}-06$ & $<5 \mathrm{E}-6$ & $<5 \mathrm{E}-6$ \\
\hline TCM-4 & $\mathrm{V}$ & $4 / 27 / 99$ & 13.48 & 10.19 & 1.16 & 109.07 & $<0.40$ & $1.56 \mathrm{E}-04$ & $8.75 \mathrm{E}-06$ & $5.00 \mathrm{E}-06$ & $1.28 \mathrm{E}-04$ \\
\hline TCM-4A & $\mathrm{V}$ & $4 / 27 / 99$ & 13.91 & 8.66 & & 106.51 & $<0.40$ & $1.63 \mathrm{E}-04$ & $6.65 \mathrm{E}-06$ & $6.00 \mathrm{E}-06$ & $8.50 \mathrm{E}-05$ \\
\hline & & Average & 14.72 & 5.57 & 0.93 & 109.53 & $<0.40$ & $6.60 \mathrm{E}-04$ & $4.43 \mathrm{E}-06$ & $5.25 \mathrm{E}-06$ & $5.58 \mathrm{E}-05$ \\
\hline TGSC-1 & $\mathrm{V}$ & $4 / 7 / 99$ & 8.20 & 3.10 & 1.14 & 0.73 & $<0.40$ & 0.48 & 1.10 & $2.59 \mathrm{E}-03$ & $5.03 \mathrm{E}-04$ \\
\hline TGSC-1A & V & $4 / 7 / 99$ & 8.12 & 3.52 & & 1.17 & $<0.40$ & 0.47 & 0.97 & $2.58 \mathrm{E}-03$ & $5.62 \mathrm{E}-04$ \\
\hline TGSC-1 & $\mathrm{V}$ & $4 / 27 / 99$ & 7.44 & 2.60 & 1.37 & 2.23 & $<0.40$ & 0.63 & 1.51 & $2.60 \mathrm{E}-03$ & $6.02 \mathrm{E}-04$ \\
\hline TGSC-1A & $\mathrm{V}$ & $4 / 27 / 99$ & 7.46 & 2.07 & & 2.09 & $<0.40$ & 0.62 & 1.64 & $2.58 \mathrm{E}-03$ & $6.48 \mathrm{E}-04$ \\
\hline & & Average & 7.81 & 2.82 & 1.26 & 1.56 & $<0.40$ & 0.55 & 1.30 & $2.59 \mathrm{E}-03$ & $5.79 \mathrm{E}-04$ \\
\hline SDP-1 & $\mathrm{V}$ & $4 / 7 / 99$ & 6.16 & 1.31 & 0.94 & 0.95 & $<0.40$ & 0.73 & 1.47 & $3.30 \mathrm{E}-03$ & $6.87 \mathrm{E}-04$ \\
\hline SDP-1A & $\mathrm{V}$ & $4 / 7 / 99$ & 5.72 & 1.22 & & 1.06 & $<0.40$ & 0.74 & 1.47 & $3.24 \mathrm{E}-03$ & $6.91 \mathrm{E}-04$ \\
\hline SDP-1 & $\mathrm{V}$ & $4 / 27 / 99$ & 8.18 & 2.15 & 1.07 & 1.54 & $<0.40$ & 0.74 & 1.50 & $2.36 \mathrm{E}-03$ & $6.28 \mathrm{E}-04$ \\
\hline SDP-1A & $\mathrm{V}$ & $4 / 27 / 99$ & 5.30 & 9.82 & & 2.49 & $<0.40$ & 0.68 & 1.38 & $2.49 \mathrm{E}-03$ & $6.74 \mathrm{E}-04$ \\
\hline \multirow{2}{*}{\multicolumn{3}{|c|}{$\begin{array}{r}\text { Average } \\
\text { Detection Limits }\end{array}$}} & 6.34 & 3.63 & 1.01 & 1.51 & $<0.40$ & 0.72 & 1.45 & $2.85 \mathrm{E}-03$ & $6.70 \mathrm{E}-04$ \\
\hline & & & 0.40 & 0.15 & 0.01 & 0.60 & 0.40 & $1.50 \mathrm{E}-05$ & $6.05 \mathrm{E}-08$ & $5.00 \mathrm{E}-06$ & $5.00 \mathrm{E}-06$ \\
\hline
\end{tabular}

$\mathrm{W}=$ Water

$\mathrm{V}=$ Vapor

Note: The averages utilized the results that were less than the detection limit by assuming that such a result equaled the detection limit 
Appendix D-2, Averaged Analytical Data (continued)

Microseeps AM-19 Gas Analysis

\begin{tabular}{|c|c|c|c|c|c|c|c|c|c|c|}
\hline Location & Matrix & $\begin{array}{c}\text { Sample } \\
\text { Date }\end{array}$ & $\begin{array}{c}\mathrm{N}_{2} \\
(\% / \mathrm{V})\end{array}$ & $\begin{array}{c}\mathrm{O}_{2} \\
(\% / \mathrm{V})\end{array}$ & $\begin{array}{c}\mathrm{CO}_{2} \\
(\% / \mathrm{V})\end{array}$ & $\begin{array}{c}\mathrm{CO} \\
(\% / \mathrm{V})\end{array}$ & $\begin{array}{c}\mathrm{CH}_{4} \\
(\% / \mathrm{V})\end{array}$ & $\begin{array}{c}\mathrm{H}_{2} \\
(\% / \mathrm{V})\end{array}$ & $\begin{array}{c}\mathrm{C}_{2} \mathrm{H}_{6} \\
(\% / \mathrm{V})\end{array}$ & $\begin{array}{c}\mathrm{C}_{2} \mathrm{H}_{4} \\
(\% / \mathrm{V})\end{array}$ \\
\hline TGSC-1-AC-1-1B & $\mathrm{V}$ & $8 / 24 / 98$ & 46.42 & 4.96 & $<0.01$ & $<0.01$ & 1.95 & 41.28 & $4.14 \mathrm{E}-03$ & $6.08 \mathrm{E}-04$ \\
\hline TGSC-1-AC-2-1B & $\mathrm{V}$ & $8 / 24 / 98$ & 46.07 & 4.79 & $<0.01$ & $<0.01$ & 1.99 & 40.70 & $4.21 \mathrm{E}-03$ & $6.18 \mathrm{E}-04$ \\
\hline & Average & 46.25 & 4.88 & $<0.01$ & $<0.01$ & 1.97 & 40.99 & $4.18 \mathrm{E}-03$ & $6.13 \mathrm{E}-04$ \\
\hline
\end{tabular}

Microseeps AM-19 Gas Analysis

\begin{tabular}{|l|c|c|c|c|c|c|c|c|c|c|}
\hline Location & Matrix & $\begin{array}{c}\text { Sample } \\
\text { Date }\end{array}$ & $\begin{array}{c}\mathrm{N}_{2} \\
(\% / \mathrm{V})\end{array}$ & $\begin{array}{c}\mathrm{O}_{2} \\
(\% / \mathrm{V})\end{array}$ & $\begin{array}{c}\mathrm{CO}_{2} \\
(\% / \mathrm{V})\end{array}$ & $\begin{array}{c}\mathrm{CO} \\
(\% / \mathrm{V})\end{array}$ & $\begin{array}{c}\mathrm{CH}_{4} \\
(\% / \mathrm{V})\end{array}$ & $\begin{array}{c}\mathrm{H}_{2} \\
(\% / \mathrm{V})\end{array}$ & $\begin{array}{c}\mathrm{C}_{2} \mathrm{H}_{6} \\
(\% / \mathrm{V})\end{array}$ & $\begin{array}{c}\mathrm{C}_{2} \mathrm{H}_{4} \\
(\% / \mathrm{V})\end{array}$ \\
\hline $\mathrm{SC}-1$ & $\mathrm{~V}$ & $4 / 27 / 99$ & 78.71 & 23.46 & 0.07 & $<0.02$ & 0.001 & 0.68 & $4.00 \mathrm{E}-06$ & $2.00 \mathrm{E}-06$ \\
\hline $\mathrm{SC}-1 \mathrm{~A}$ & $\mathrm{~V}$ & $4 / 27 / 99$ & 73.18 & 21.60 & 0.06 & $<0.02$ & 0.18 & 10.96 & $2.00 \mathrm{E}-04$ & $2.70 \mathrm{E}-05$ \\
\hline \multicolumn{2}{r}{ Average } & 75.95 & 22.53 & 0.07 & $<0.02$ & 0.09 & 5.82 & $1.02 \mathrm{E}-04$ & $1.45 \mathrm{E}-05$ \\
\hline
\end{tabular}

$\mathrm{W}=$ Water

$\mathrm{V}=$ Vapor 


\section{Appendix D-3, Calculated Dissolved Gas Saturation Concentration in Equilibrium with Atmospheric Air}

\begin{tabular}{|c|c|}
\hline Gas & $\begin{array}{c}\text { CRC } \\
\text { Atmospheric } \\
\text { Dry Air } \\
\text { Concentration } \\
(\% / \mathrm{V})\end{array}$ \\
\hline $\mathrm{N}_{2}$ & $78.084^{1}$ \\
\hline $\mathrm{O}_{2}$ & $20.9476^{1}$ \\
\hline $\mathrm{CO}_{2}$ & $0.0314^{1}$ \\
\hline $\mathrm{CO}^{1}$ & $6 \mathrm{E}-06$ to $1 \mathrm{E}-04^{2}$ \\
\hline $\mathrm{CH}_{4}$ & $0.0002^{1}$ \\
\hline $\mathrm{H}_{2}$ & $0.00005^{1}$ \\
\hline $\mathrm{C}_{2} \mathrm{H}_{6}$ & $5.0 \mathrm{E}-09$ to $9.5 \mathrm{E}-06^{3}$ \\
\hline $\mathrm{C}_{2} \mathrm{H}_{4}$ & $7.0 \mathrm{E}-08$ to $7.0 \mathrm{E}-05^{3}$ \\
\hline
\end{tabular}

Notes: ${ }^{1}$ Lide, $1998 ;{ }^{2}$ Mirtov, $1964 ;{ }^{3}$ Graedel, 1978

\section{Calculated Dissolved Gas Saturation Concentration in Equilibrium with Atmospheric Air at $17^{\circ} \mathrm{C}$}

\begin{tabular}{|c|c|c|c|c|c|c||}
\hline Gas & $\begin{array}{c}\text { Atmospheric } \\
\text { Dry Air } \\
\text { Concentration } \\
(\% / \mathrm{V})\end{array}$ & $\begin{array}{c}\mathrm{p} \\
(\mathrm{atm})\end{array}$ & $\begin{array}{c}\mathrm{K}^{1} \\
\mathrm{at} \\
17^{\circ} \mathrm{C}\end{array}$ & $\begin{array}{c}\mathrm{a}^{2} \\
(\text { moles } / \mathrm{L})\end{array}$ & $\begin{array}{c}\text { Atomic } \\
\text { Weight } \\
(\mathrm{g} / \mathrm{mole})\end{array}$ & $\begin{array}{c}\text { Dissolved } \\
\text { Gas } \\
\text { Concentration } \\
(\mathrm{mg} / \mathrm{L})\end{array}$ \\
\hline $\mathrm{N}_{2}$ & 78.084 & 0.781 & $7.37 \mathrm{E}-04$ & $5.75 \mathrm{E}-04$ & 28.01 & 16.11 \\
\hline $\mathrm{O}_{2}$ & 20.9476 & 0.209 & $1.56 \mathrm{E}-03$ & $3.27 \mathrm{E}-04$ & 32.00 & 10.45 \\
\hline $\mathrm{CO}_{2}$ & 0.0314 & $3.1 \mathrm{E}-04$ & $4.37 \mathrm{E}-02$ & $1.37 \mathrm{E}-05$ & 44.01 & 0.60 \\
\hline $\mathrm{CO}$ & $6.0 \mathrm{E}-06$ & $6.0 \mathrm{E}-08$ & $1.03 \mathrm{E}-03$ & $6.19 \mathrm{E}-11$ & 28.01 & $1.7 \mathrm{E}-06$ \\
\hline $\mathrm{CO}$ & $1.0 \mathrm{E}-04$ & $1.0 \mathrm{E}-06$ & $1.03 \mathrm{E}-03$ & $1.03 \mathrm{E}-09$ & 28.01 & $2.9 \mathrm{E}-05$ \\
\hline $\mathrm{CH}_{4}$ & $2.0 \mathrm{E}-04$ & $2.0 \mathrm{E}-06$ & $1.59 \mathrm{E}-03$ & $3.2 \mathrm{E}-09$ & 16.04 & $5.1 \mathrm{E}-05$ \\
\hline $\mathrm{H}_{2}$ & $5.0 \mathrm{E}-05$ & $5.0 \mathrm{E}-07$ & $8.83 \mathrm{E}-04$ & $4.4 \mathrm{E}-10$ & 2.02 & $8.9 \mathrm{E}-07$ \\
\hline $\mathrm{C}_{2} \mathrm{H}_{6}$ & $5.0 \mathrm{E}-09$ & $5.0 \mathrm{E}-11$ & $2.16 \mathrm{E}-03$ & $1.1 \mathrm{E}-13$ & 30.07 & $3.2 \mathrm{E}-09$ \\
\hline $\mathrm{C}_{2} \mathrm{H}_{6}$ & $9.5 \mathrm{E}-06$ & $9.5 \mathrm{E}-08$ & $2.16 \mathrm{E}-03$ & $2.0 \mathrm{E}-10$ & 30.07 & $6.2 \mathrm{E}-06$ \\
\hline $\mathrm{C}_{2} \mathrm{H}_{4}$ & $7.0 \mathrm{E}-08$ & $7.0 \mathrm{E}-10$ & $6.81 \mathrm{E}-03$ & $4.8 \mathrm{E}-12$ & 28.05 & $1.3 \mathrm{E}-07$ \\
\hline $\mathrm{C}_{2} \mathrm{H}_{4}$ & $7.0 \mathrm{E}-05$ & $7.0 \mathrm{E}-07$ & $6.81 \mathrm{E}-03$ & $4.8 \mathrm{E}-09$ & 28.05 & $1.3 \mathrm{E}-04$ \\
\hline
\end{tabular}

Notes:

Henry's Law: $\mathrm{K}=\mathrm{a} / \mathrm{p}$

$\mathrm{a}=$ aqueous concentration, moles $/ \mathrm{L} ; \mathrm{p}=$ gas phase concentration in atmospheres

${ }^{1} \mathrm{~K}$ values from Roine, 1997

${ }^{2} \mathrm{a}=\mathrm{K} \times \mathrm{p}$

${ }^{3}$ Dissolved Gas Concentration $=(\mathrm{a} \times$ At. Wt. $) \times 1000$ 
Appendix D-4, Calculated Normalized Equilibrium Gas Phase Concentration in Equilibrium with the Siphon Discharge Point Average Dissolved Gas Concentration

\begin{tabular}{|c|c|c|c|c|c|c|c|}
\hline Gas & $\begin{array}{l}\text { SDP Average } \\
\text { Dissolved } \\
\text { Gas } \\
\text { Concentration } \\
(\mathrm{mg} / \mathrm{L})\end{array}$ & $\begin{array}{c}\text { Atomic } \\
\text { Weight } \\
(\mathrm{g} / \mathrm{mole})\end{array}$ & $\begin{array}{c}\mathrm{a} \\
(\mathrm{moles} / \mathrm{L})\end{array}$ & $\begin{array}{c}\mathrm{K}^{1} \\
\text { at } \\
17^{\circ} \mathrm{C}\end{array}$ & $\begin{array}{c}\mathrm{p}^{2} \\
\text { (atm) }\end{array}$ & $\begin{array}{c}\text { Equilibrium } \\
\text { Gas } \\
\text { Phase }^{3} \\
\text { Concentration } \\
(\% / \mathrm{V})\end{array}$ & $\begin{array}{c}\text { Normalized } \\
\text { Equilibrium } \\
\text { Gas } \\
\text { Phase }^{4} \\
\text { Concentration } \\
(\% / V)\end{array}$ \\
\hline $\mathrm{N}_{2}$ & 6.34 & 28.01 & $2.26 \mathrm{E}-04$ & $7.37 \mathrm{E}-04$ & 0.307 & 30.72 & 26.19 \\
\hline$\overline{\text { Field } \mathrm{O}_{2}}$ & 1.01 & 32.00 & $3.14 \mathrm{E}-05$ & $1.56 \mathrm{E}-03$ & 0.020 & 2.01 & 1.72 \\
\hline $\mathrm{CH}_{4}$ & 0.72 & 16.04 & $4.50 \mathrm{E}-05$ & $1.59 \mathrm{E}-03$ & 0.028 & 2.83 & 2.41 \\
\hline $\mathrm{H}_{2}$ & 1.45 & 2.02 & $7.22 \mathrm{E}-04$ & $8.83 \mathrm{E}-04$ & 0.818 & 81.76 & 69.68 \\
\hline & & & & Total & 1.173 & 117.33 & 100.00 \\
\hline
\end{tabular}

Notes:

SDP $=$ Siphon Discharge Point

Henry's Law: $K=a / p$ $\mathrm{a}=$ aqueous concentration, moles $/ \mathrm{L} ; \mathrm{p}=$ gas phase concentration in atmospheres $\mathrm{a}=(\mathrm{SDP}$ Average $\times \mathrm{g} / 1000 \mathrm{mg}) /$ atomic weight

${ }^{1} \mathrm{~K}$ values from Roine, 1997

${ }^{2} \mathrm{p}=\mathrm{a} / \mathrm{K}$

${ }^{3}$ Equilibrium Gas Phase Concentration $=(\mathrm{p} / 1 \mathrm{~atm}) \times 100$

${ }^{4}$ Normalized Gas Phase Concentration $=($ Equilibrium Gas Phase Concentration $/ 117.33) \times 100$ 
Left Blank Intentionally 
APPENDIX E

CREATIVITY COMMITTEE MEETING MINUTES 
June 1999

\section{CREATIVITY COMMITTEE MEETING}

Topic:

Date:

Time:

Place:

Meeting Managers:
Improved Siphoning Methods for Treating VOCs in Groundwater

June 23, 1999

12:30 Noon - 3:30 PM

773-A, ABC Conference Room

Tim Smail (952-6806)

Coleman Miles (952-6695)

Cassie Bayer (952-6814)

Paul Hebert (725-1261

\section{STATEMENT OF THE PROBLEM}

The Geosiphon is effectively treating VOCs in groundwater. However, it has been unable to maintain a passive or maintenance-free siphon, due primarily to gas generation during treatment.

1) What methods exist that eliminate or reduce gas generated during treatment?

2) What no-maintenance options exist for operating the siphon with existing gas generation?

3) What low-maintenance options exist to cost effectively operate the siphon with the existing gas generation?

\section{BACKGROUND INFORMATION:}

Technology development is being evaluated at the TNX Area which combines existing technologies of permeable treatment media (zero valent iron fillings) and a siphon to produce passive (no maintenance) in situ groundwater treatment. This zero valent iron treatment $\mathrm{w} /$ siphon system passively induces contaminated groundwater flow through in situ permeable treatment media at an accelerated rate by utilizing a siphon between two points of natural hydraulic head difference at TNX. Zero valent iron is used to produce abiotic degradation of chlorinated volatile organic compounds. Granular cast iron ( $\mathrm{Fe} 0$ ) is used as the reducing agent and produces final reaction products such as methane, ethane, ethene, and chloride ions in the degradation of TCE as well as hydrogen gas as a result of hydrolysis and nitrogen gas from dissolved air.

The zero valent iron treatment cell is an 8-foot diameter well filled with iron filings. A 12-inch diameter screen and casing were placed in the center of the iron filings to allow insertion of the siphon line and withdrawal of the treated groundwater. The siphon line pulls treated water from within the 12-inch diameter casing and discharges the treated water to a ditch. The head differential between the treatment cell and the discharge point is approximately 3.1 feet but may vary 1 to 4 feet as water table and surface water elevations change.

The siphon is essentially a passive vacuum pump. Siphons require priming (initial filling of line) to initiate flow. After priming, the siphon will passively convey liquid from the point of higher hydraulic head to the one of lower head indefinitely as long as the head differential is maintained and the prime is not lost.

During treatment of the groundwater by the granular cast iron within the cell, reduced gases are produced. The reduced gases in the treated water are degassing and creating air pockets within the siphon line. The air pocket grows over time and restricts the flow. Primary gases of concern are nitrogen (46), hydrogen (41\%), methane (2\%), and oxygen ( $5 \%)$. The remainder of the gas is made up of predominantly water vapor $(-5-6 \%)$, since the gas is produced from degassing water under a vacuum (approximately 6 in $\mathrm{Hg}$ of vacuum). Additionally, part per million by volume levels of ethane, ethene, propane, propylene, and butane, and part per billion by volume levels of 1,1,1trichloroethylene and trichloroethylene were detected.

A brief synopsis of the tests conducted to date is listed below. The siphon line is not currently operating.

- Phase I tested the effectiveness of the zero valent iron. This test was conducted using a pump. Results indicated that the zero valent iron is an effective means of treating VOCs in the groundwater at TNX. 
- The Phase II was conducted to test the siphon line. The original siphon line was approximately $1000 \mathrm{ft}$ and ran from the treatment cell to the Savannah River. Attempts to maintain the siphon in this configuration failed due to gas generation in the line. Air pockets developed within the line at the localized highs and lows since the siphon was laid directly on the ground. It was determined that an engineered grade and an air chamber were needed.

- An air chamber ( $\sim 7$ gallons) was added on the siphon line at various locations to capture the entrained gases.

- The first chamber was located at the treatment cell with the $1000-\mathrm{ft}$ of siphon line after the chamber. The siphon line discharged into the river. The air chamber was elevated with a 1:100 downward slope from the cell to the outfall ditch. This location proved to be ineffective in maintaining the siphon long term.

- The second attempt with the air chamber concept was to move the chamber to an artificial high point approximate $280-\mathrm{ft}$ from the treatment cell with an upward slope of 1:100 to the outfall ditch. The remaining $720-\mathrm{ft}$ of siphon line remained lying in the outfall ditch and discharged into the river. This proved to be ineffective in maintaining the siphon long term.

- The third attempt with the air chamber concept was the same as the second with the exception that the siphon line was shortened by approximately $700-\mathrm{ft}$. The discharge was now in the outfall ditch instead of the river. This attempt was effective, however the air chamber required manual purging every 24 hours to maintain the siphon. The testing was shut down due to safety concerns with the build up of explosive gases in the air chamber.

- The last test conducted was to try sweeping the air bubbles through the siphon line by increasing the flushing velocity using reduced line diameter. This was to be done by connecting a smaller diameter pipe to a larger diameter pipe at the high point in the siphon line. The siphon line was reconfigured to have a 2-3\% slope upward from the treatment cell. A continuous 2 in. line was tried first as a baseline. The next attempt was a $1 \mathrm{in}$. line connected to the 2 in. line at the high point. Neither attempt was successful in maintaining a siphon.

\section{EXECUTIVE SUMMARY}

The GeoSiphon system is effective in treating chlorinated volatile organic compounds (CVOC) in the TNX area groundwater. The system as currently configured, however, has been unable to maintain a passive or maintenancefree siphon, due primarily to gas generation during treatment by the iron filings and from the existing dissolved gases. The primary gases of concern are hydrogen and methane generated during the treatment and nitrogen and oxygen which exist within the groundwater. These gases create pockets within the siphon line, which grow over time restricting flow and eventually breaking the siphon.

These concerns were addressed at the June 23, 1999 Creativity Committee Meeting. Discussions focused on eliminating gas generation and identification of no maintenance and low maintenance options to operate the system under existing conditions.

The following general concepts were identified for eliminating gas generation:

- Change from iron filings to an alternative treatment media

- Add additional treatment media to remove, dissolve, or entrain existing gases

- Remove gases after generation before entering siphon line

No and low maintenance alternatives discussed fall into the following categories:

- Modification of the siphon line (i.e., gravity flow, line insulation, increased flow, etc.)

- Continuous gas removal options (i.e., eductors, low volume automated purging air chambers, in-line air separators, etc.)

- Automatic re-priming and/or purging

- For future systems, relocate the treatment cell to the tail-end of the siphon to eliminate the gas bubble problem

- Use of pumps

At various points during the discussion laboratory support testing, including parametric studies, was suggested as a method for isolating the source of the siphon loss, better understanding of the problem, and providing a convenient method for evaluating potential modifications or solutions. The methods and techniques suggested during the Creativity Committee Meeting will now be evaluated to determine the best solutions to maintaining a siphon treatment system at the TNX area. 


\section{AGENDA}

Meeting Process

Welcome

Introductions

Problem Statement/

Background of Problem

Presentation:

"GeoSiphon"

Clarification

Break

Brainstorming

Customer Q\&A /Evaluation

Resources

Wrap-up

Reflections

$\begin{array}{ll}\text { George } & 5 \mathrm{~min} . \\ \text { George } & 5 \mathrm{~min} . \\ \text { All } & 10 \mathrm{~min} . \\ \text { Coleman } & 15 \mathrm{~min} . \\ & \\ \text { Cassie } & 30 \mathrm{~min} . \\ \text { All } & 20 \mathrm{~min} . \\ \text { All } & 20 \mathrm{~min} . \\ \text { All } & 60 \mathrm{~min} . \\ \text { All } & 15 \mathrm{~min} . \\ \text { All } & 10 \mathrm{~min} . \\ \text { Tim } & 5 \mathrm{~min} . \\ \text { All } & 5 \mathrm{~min} .\end{array}$

\section{BRAINSTORMING}

\section{Methods to Eliminate or Reduce Generated Gas}

- Possible inleakage - Leak test pipe

- Reduce maximum height of siphon

- Agitate the filtrate liquid to drive gases out

- Oxidize water after treatment

- granular flow-through solid oxidant

- liquid addition hydrogen peroxide

- Use material of construction that would allow gas removal

- Use solid gel metal hydrides

- Use membrane technology for gas diffusion

- Use these technologies to reduce flammability concerns

- Other alloys have different oxidation potentials to minimize gas generation

- Are any hoses air permeable?

- Any terms controlling $\mathrm{pH}$ or Eh

- Catalyst with lower potential

- $\quad$ HH adjustment back to 7

- Fine tune redox potential closer to that necessary to destroy contaminants

- These technologies to be used for all of gases of interest

- Can you add something to the flow? Use chemical or mechanical means to reduce the bubble size or raise solubility

- Adjust $\mathrm{pH}$ to control solubility of hydrogen - Reduce $\mathrm{pH}$ increase solubility of gas

- Use hydrogen in tank as fuel source

- Parametric laboratory support study would help

- Inject substance into filtrate (treat bubbles after generated)

- Add reducing agent like sodium bisulfite, ex., for oxygen

- Treatment at tail end of siphon

- Add rotation to siphon flow; put veins in pipes 
Page $\underline{4}$ of $\underline{5}$

\section{No-or-Low Maintenance Options to Operate Siphon with Existing Gas}

- Some small mechanical device, powered on its own

- In-line or above line air separators

- Bell \& Gossett Steam Separators

- In line Steam Separator

- Automate siphon restoration process to minimize gas problem

- Mechanically remove gas from reservoir, sensing with a float \& pumping with an eductor driven by high pressure air

- Eliminate siphon; install pump

- Let flowing water create eductor to evacuate gas out of high point of line

- Use flow of Savannah River

- Large diameter venturi eductor in river flow

- best siphon

- use with line up to top to pull gas out

- Use flowing water to drive turbine pump

- Insulate line or put underground to keep temperature down to maximum solubility of gas

- Use total gravity flow from filtrate (casing)

- Use large air chamber

- Have laboratory studies to support fieldwork

- Take advantage of buoyancy of gas to remove from system

- Create vortex in flow to trap bubbles and increase flow

- Run small vacuum pump; use solar powered pump

- Ultrasonically excite gas bubbles to keep small

- Multiple gas collection points of smaller volumes and keep evacuated by outlet eductor

- Line using buoyancy effect, line with small hole at top (outlet holes or ports to vent gas)

- Membranes to separate gas from water

- One-piece pipe so no place for air to collect

- Put venturi at end of pipe, run small tubing from venturi pipe to gas pocket (the more head the better)

- Are there eductors that can run $<30$ psi? 


\section{RESOURCES}

$\begin{array}{lll}\text { Water Driven Eductors } & \text { John Steimke } & 5-1500 \\ & \text { Dan Burns } & 5-2607 \\ & \text { Rich Dimenna } & 5-8203 \\ \text { Steve Tibrea } & 5-3210 \\ \text { Absorbers } & & \\ \quad \text { - Membranes } & \text { Steve Serkiz } & 5-5422 \\ \quad \text { - Sol Gel Metal Hydrides } & \text { Myung Lee } & 5-1726 \\ & \text { Kit Heung } & 5-3161 \\ \text { Chemical } & \text { George Wicks } & 5-3190 \\ \text { Inline Air Separators } & \text { Scott Reboul } & 2-6787 \\ \text { Vortex } & \text { Tim Hagstrom } & 5-5582 \\ \text { Lab Support / Parametric Studies } & \text { Bob Rapp } & 2-9445 \\ \text { Catalytic Effects } & \text { Marty Pechersky } & 5-1137 \\ & \text { Dan Burns' Group } & 5-2607 \\ & & \\ & \text { Bob Hochel } & 5-1344 \\ & \text { Al Boni's Group } & 5-2628\end{array}$

\section{REFLECTIONS}

+ Meeting managers did superb job.

+ Good group

+ Excellent brain power

+ Participants realize that engineering can be fun.

+ Asking for help or input from colleagues beneficial

+ Suggestion to have working easels available in room for sketches of ideas or new concepts. 